\title{
P R I N C E T O N \\ S E M I N A R Y \\ B U L L E T I N
}

\section{O L U M E $30 \begin{array}{lllll}2 & 0 & 0 & 9\end{array}$}

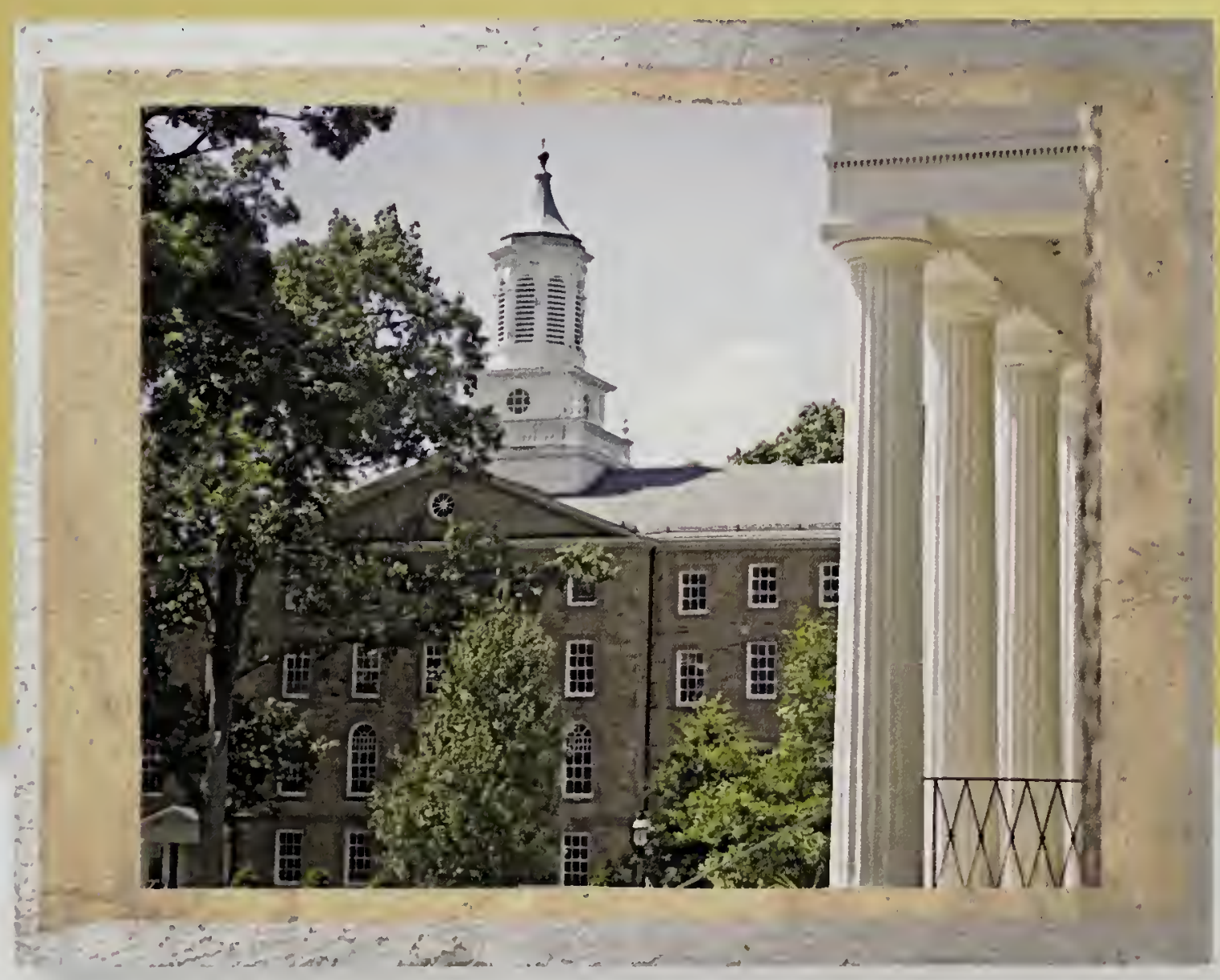

Anderson $\cdot$ Cooper-White $\cdot$ Dykstra $\cdot$ Elwood $\cdot$ Fergusson $\cdot$ Jarvis Lovin $\cdot$ May $\cdot$ Myers $\cdot$ Powery $\cdot$ Sunquist $\cdot$ Tyson $\cdot$ Zachman 
Digitized by the Internet Archive in 2018 with funding from

Princeton Theological Seminary Library 


\section{P R I N C E T O N \\ S E M I N A R Y \\ B U L L E T I N \\ VOLUME $30 \mid 2009$}

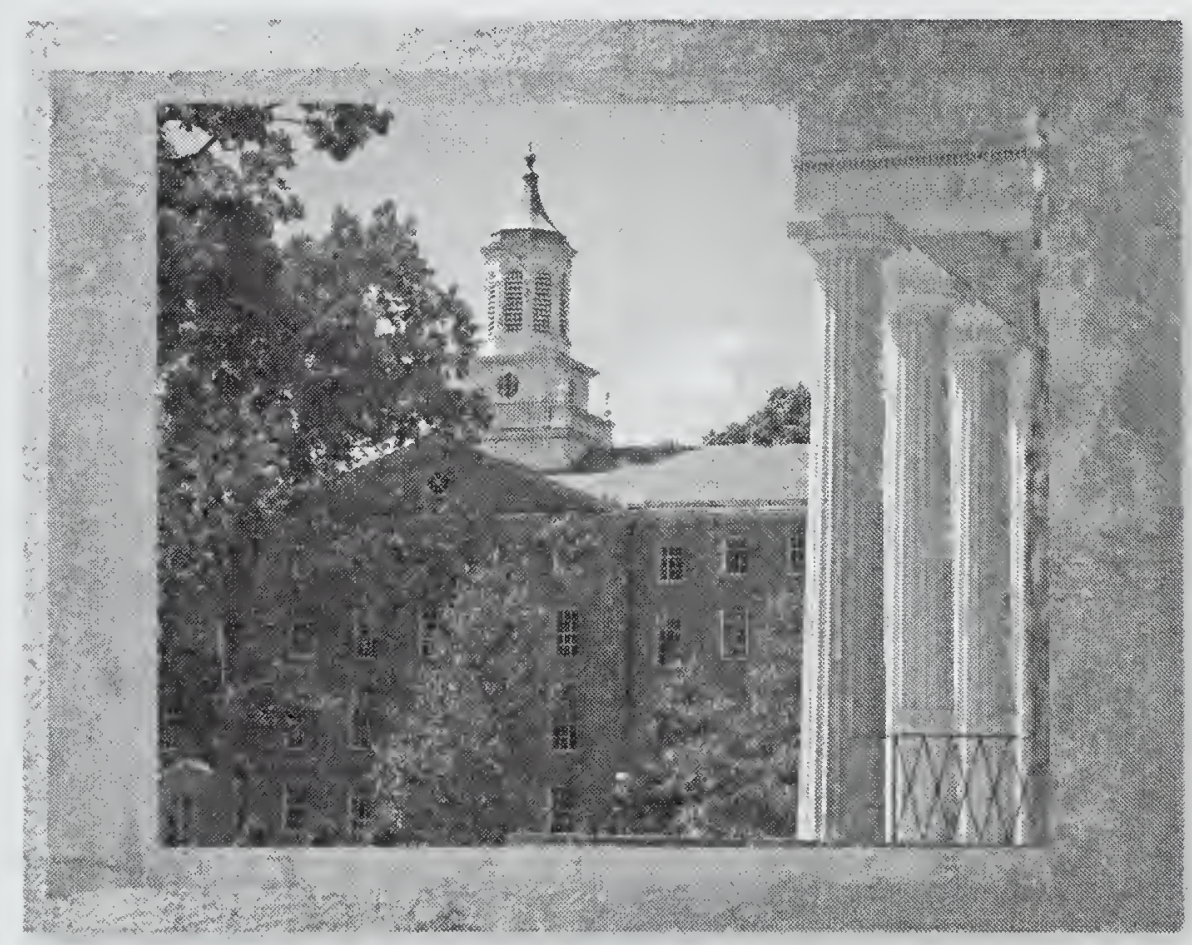

Stephen D. Crocco, Editor

Mary M. Astarita, Managing Editor

$\frac{P}{\text { D P R I N C E T O O N }}$ 



\author{
Iain R. Torrance, President
}

\title{
Board of Trustees \\ Robert W. Bohl, Chair \\ Leslie W. Braksick, Vice Chair John T. Galloway Jr., Secretary
}

\author{
Robert M. Adams \\ Fred R. Anderson \\ M. Craig Barnes \\ William L. Bowers \\ Amy Woods Brinkley \\ Martha Z. Carter \\ Warren D. Chinn \\ Gary O. Dennis \\ John H. Donelik \\ Michael G. Fisch \\ Mary Lee Fitzgerald \\ Francisco O. Garcia-Treto \\ Joan I. Gotwals \\ Nancy Oliver Gray \\ Heather Sturt Haaga \\ C. Thomas Hilton
}

\author{
Craig A. Huff \\ Dorothy A. Johnson \\ Thomas R. Johnson \\ Todd B. Jones \\ F. Carter Karins \\ Jinsoo Kim \\ James H. Logan Jr. \\ David M. Mace \\ Kari Turner McClellan \\ Deborah A. McKinley \\ Neal D. Presa \\ William P. Robinson \\ Thomas J. Rosser \\ Virginia J. Thornburgh \\ George B. Wirth \\ Susan F. Wonderland
}

\section{Trustees Emeriti/ae}

Clarence B. Ammons

Stewart B. Clifford

Peter E. B. Erdman

Rosemary Hall Evans

Sarah Belk Gambrell

David H. Hughes

F. Martin Johnson

Justin M. Johnson

Johannes R. Krahmer
Young Pai

Earl F. Palmer

Wiliam H. Scheide

Arthur F. Sueltz

Paul E. Vawter Jr.

Samuel G. Warr

David B. Watermulder

Jane C. Wright

Ralph M. Wyman 


\title{
PRINCETON THEOLOGICAL SEMINARY
}

\author{
The Faculty, 2008-2009
}

$\begin{array}{lll}\text { Kenneth G. Appold } & \text { L. Gordon Graham } & \text { Gordon S. Mikoski } \\ \text { Shane Berg } & \text { Nancy Lammers Gross } & \text { James H. Moorhead } \\ \text { C. Clifton Black II } & \text { Darrell L. Guder } & \text { Dennis T. Olson } \\ \text { John R. Bowlin } & \text { Deborah van Deusen Hunsinger } & \text { Richard R. Osmer } \\ \text { Michael A. Brothers } & \text { George Hunsinger } & \text { George L. Parsenios } \\ \text { Sally A. Brown } & \text { Jeremy M. Hutton } & \text { Yolanda Pierce } \\ \text { James H. Charlesworth } & \text { W. Stacy Johnson } & \text { Luke A. Powery } \\ \text { Ellen T. Charry } & \text { James F. Kay } & \text { Paul E. Rorem } \\ \text { Stephen D. Crocco } & \text { Jacqueline E. Lapsley } & \text { Katherine Doob Sakenfeld } \\ \text { Kenda Creasy Dean } & \text { Cleophus J. LaRue } & \text { Choon-Leong Seow } \\ \text { James C. Deming } & \text { Bo Karen Lee } & \text { Loren T. Stuckenbruck } \\ \text { Frederick W. Dobbs-Allsopp } & \text { Eunny Patricia Lee } & \text { Mark L. Taylor } \\ \text { Nancy J. Duff } & \text { Sang Hyun Lee } & \text { Martin Tel } \\ \text { Robert C. Dykstra } & \text { Bruce L. McCormack } & \text { J. Wentzel van Huyssteen } \\ \text { Richard K. Fenn } & \text { Elsie Anne McKee } & \text { J. Ross Wagner } \\ \text { Beverly Roberts Gaventa } & \text { Kathleen E. McVey } & \text { Richard Fox Young }\end{array}$

\section{Emeriti/ae}

Diogenes Allen

James F. Armstrong

Richard S. Armstrong

Charles L. Bartow

William Brower

Donald E. Capps

Jane Dempsey Douglass

Elizabeth G. Edwards

Abigail Rian Evans

\author{
Karlfried Froelich \\ Freda A. Gardner \\ Thomas W. Gillespie \\ Geddes W. Hanson \\ Scott H. Hendrix \\ James N. Lapsley Jr. \\ Conrad H. Massa \\ Paul W. Meyer \\ Daniel L. Migliore \\ Patrick D. Miller
}

Samuel Hugh Moffett

Peter J. Paris

Luis N. Rivera-Pagán

J. J. M. Roberts

Charles A. Ryerson III

Max L. Stackhouse

John W. Stewart

Charles C. West

E. David Willis 


\section{Princeton}

\section{Seminary}

2009

Bulletin

ontents

1 Editor's Note

Stephen D. Crocco

\section{Convocation Address}

$4 \quad$ Finding Ourselves Lost

Robert C. Dykstra

\section{Baccalaureate Sermon}

16 Tracks of My Tears

Luke A. Powery

\section{Lectures}

22 Africa's Hands: Pentecostalism and Independency

Allan Anderson

38 The Role of Feminism(s) in Theology and the Church: Reflections from a Feminist Pastoral Theologian

Pamela Cooper-White

63 Getting Calvin Right: How Karl Barth Changed Our Reading of the Reformer

Christopher Elwood

81 Ministry in the Subjunctive Mood

Cynthia A. Jarvis

95 The Theology of Providence

David Fergusson

112 Politics in the Christian Life

Robin W. Lovin

127 Containing Runaway Fear in American Foreign Policy

William F. May

152 Karl Barth and Contemporary

Paganism: Toward a Theology without Nature

Benjamin Myers

180 Time, the Lectures, and Redemption

Scott W. Sunquist 
193 Blood Done Sign Our Names: Blues, Gospel, and Jazz Impulses in the Age of Obama

Timothy B. Tyson

204 The Beauty and Terror of the Universe:

John Calvin and Blaise Pascal

Randall C. Zachman

\section{Faculty Publications 2008}

\section{(C) 2009 Princeton Seminary Bulletin}

The Princeton Seminary Bulletin is published annually by Princeton Theological Seminary, Princeton, New Jersey.

Issues can be digitally accessed at: http://digital.library.ptsem.edu/bulletin/. Recent issues, printed on demand for a modest price, can be ordered from Amazon.com.

All correspondence should be addressed to Mary M. Astarita, Managing Editor, Princeton Seminary Bulletin, P.O. Box 821, Princeton NJ 08542-0803; email: seminary.bulletin@ ptsem.edu.

The Princeton Seminary Bulletin publishes lectures and sermons by Princeton Theological Seminary faculty and administrators, and presentations by guests on the Seminary campus. Therefore, we do not accept unsolicited material.

This periodical is indexed in the ATLA Religion Database, published by the American Theological Library Association, 250 S. Wacker Dr., 16th Flr., Chicago, IL 60606;

ISSN: 1937-8386; ISBN: 978-0-9644891-3-4.

Cover photo by Beckey White Newgren. 


\section{Editor's Note}

$T$

he Princeton Seminary Bulletin is still in the early stages of making its transition from a print to a primarily digital journal. More specifically, the Bulletin has gone from a paper-only journal to a journal published simultaneously in paper and digital formats, to a journal published primarily in digital format with a paper option for those who prefer print. The transition has been slow going. All of the work required to create a high-quality paper journal has to be done to create a high-quality digital journal. The difference between the two formats for the Bulletin is that in the paper years, the journal was sent to some 12,000 people and institutions. In the digital era, the journal is accessible to many millions of people and institutions via the Internet. Both versions of the Bulletin were or are accessible in different ways and to different degrees.

Accessibility, one of the great watchwords of our era, is worth some discussion. Just because something is accessible does not mean that it is read, consulted, or even skimmed. That's hardly debatable. I have no doubt that many paper issues of the Bulletin wound up unread in recycling bins or in boxes of books donated to libraries and book sales. I can just as easily imagine a busy pastor who downloads an issue of the Bulletin to his or her e-book reader but never takes the time to read the issue.

The concerns qualifying a basic sense of accessibility are discoverability, quality, and cost. Assuming something is accessible, can it be readily found or discovered? If found, is it worth reading? If it is found and if it is worth reading, is the reader willing to pay the cost to read it? With the publication of the 2010 issue of the Bulletin, look for a media campaign to remind past readers and inform future readers that the Bulletin is accessible in a variety of ways, that its quality is high, and that it is available free of charge on the Seminary website.

The Bulletin has been one of Princeton Theological Seminary's gifts to the world church for over 100 years. We believe that the content of the Princeton Seminary Bulletin remains consistently high. Moreover, the Bulletin is freely available to 
be read online, and we offer downloadable versions (such as the Amazon Kindle format). We are also liberal in our distribution policies, allowing articles to be copied or printed and used for classroom and Sunday schools, and we encourage readers to do just that. And, yes, for those of you who prefer to read in paper format, you can go to Amazon.com and purchase a print copy at a very reasonable price.

STEPHEN D. CROCCO

EDITOR 


\section{Convocation Address}

\section{Finding Ourselves Lost}

by Robert C. Dykstra

Robert C. Dykstra is the Charlotte W. Newcombe Professor of Pastoral Theology at Princeton Theological Seminary. He is the author of Images of Pastoral Care: Classic Readings (Chalice Press, 2005) and other books. He delivered this address to the students on September 20,2009, in Miller Chapel.

\section{Luke 15:1-7 (NRSV)}

$O$ $\mathrm{n}$ her first day at Princeton Seminary, having driven from California to begin her MDiv program, a dear friend of mine asked a returning student how one goes about getting to New York City from here. "Oh, it's easy," he told her. "You take the Dinky by the Wawa." "The Dinky by the Wawa?" my friend wondered. What planet had she landed on, she asked herself. The Dinky by the Wawa? What planet indeed. It was the first time but not the last that she would ask herself that question here, the first time but not the last that she would find someone speaking gibberish, the first time but not the last that she would find herself lost at Princeton Seminary.

\section{Even More Confused Than We Seem}

All kinds of words, so many strange words, some of them alien for being so familiar-books and shelves and stacks and libraries full of words like "Dinky," which is Greek for "the little engine that could," and "Wawa," which is Hebrew for "help get me through the night"- - books and shelves and stacks full of words about God, full of theo-logoi. Frederick Buechner once wrote that "theology is the study of God and [God's] ways. For all we know, dung beetles may study [human beings and their] ways and call it humanology. If so, we would probably 
be more touched and amused than irritated. One hopes that God feels likewise." I But what choice do we have, really, than to keep on talking about God, to keep on reading and writing about things of which we know so little, what choice but to embark on this impossible vocation? For that's what it is we do here, spilling sweat and ink and tuition dollars to try to get God right (or left). At a time when their words about God lead some from another faith to fly airplanes into skyscrapers and others from our own to pray publicly for our president's death, it matters what we say about God.

British psychoanalyst Adam Phillips ends his book Going Sane: Maps of Happiness, a book on the nature of sanity, by saying: "It would be sane to take for granted that everyone is even more confused than they seem. Havoc is always wreaked in fast cures for confusion. The sane believe that confusion, acknowledged, is a virtue; and that humiliating another person is the worst thing we ever do. Sanity should not be our word for the alternative to madness; it should refer to whatever resources we have to prevent humiliation."

Because "everyone is even more confused than they seem," especially at Princeton Seminary, where we compel ourselves to talk of things about which we know so little, we may want to take special care here to do all in our power to avoid humiliating others, to avoid confusing them further.

So many words about God. No wonder we find ourselves confused, find ourselves lost here from time to time.

\section{Does God Have Regard for Me?}

My friend John McDargh, a psychologist of religion at Boston College, quoting his Benedictine colleague Dom Sebastian Moore, suggests that the "primary and irreducible proposition about human beings ... is that 'we all desire to be desired by the one we desire." "' Moore writes, "The only serious form of the religious question today is: Is human awareness, when it finds its fulfillment in love, resonating, albeit faintly, with an origin that 'behaves,' infinitely and

\footnotetext{
${ }^{1}$ Frederick Buechner, Wishful Thinking: $A$ Theological ABC (New York: Harper \& Row, 1973), 91.

${ }^{2}$ Adam Phillips, Going Sane: Maps of Happiness (New York: Fourth Estate/Harper Collins, 2005), 199.

${ }^{3}$ John McDargh, "Desire, Domination, and the Life and Death of the Soul," in On Losing the Soul: Essays in the Social Psychology of Religion, R. K. Fenn and D. Capps, eds. (Albany: State University of New York Press, 1995), 213-30.
} 
all-constitutingly, as love behaves?"4 McDargh continues, "To ask this question in the poetry of the biblical tradition, 'Does God have regard for me?' or 'Am I a source of delight to the Source of my delight?"'s

This may be what those many books and shelves and stacks and libraries full of words about God, what you and I- who find ourselves lost at Princeton Seminaryare somehow endeavoring to ask: Does God have regard for me? Am I a source of delight to the source of my delight?

The answer to this question is not always as clear as one might hope at this schoolhouse, for we find ways enough to demean one another here. But if we were to take to heart the words of Jesus's parable of the one lost sheep-a parable that would be among the top contenders if I were pressed to choose the gospel within the gospel-the answer, I suspect, would be an unambiguous yes. Yes, God has regard for you. Yes, you are a source of delight to the source of your delight. This parable could go a long way toward helping us acknowledge our confusion, toward keeping us sane, and as a resource to prevent humiliation.

\section{THE ONE, OR THE MANY?}

There are plenty, especially among my fellow pastoral theologians, who would take me to task for this choice as a gospel within the gospel, despite, or perhaps because of, the fact that the academic discipline of pastoral theology was pioneered by Seward Hiltner and James Lapsley right here at Princeton Seminary in large measure on the basis of this very parable. The parable promotes, Hiltner believed, the "tender and solicitous care" of the shepherd who at times privileges the needs of the one at what increasing numbers of my colleagues fear may be the expense of the larger flock. ${ }^{6}$ Almost before Hiltner's ink was dry on the page, Carroll A. Wise of Garrett Seminary wrote in 1966 that the symbol of the shepherd advocated in Hiltner's "shepherding perspective" is too dated and rural and therefore "cannot have the power for modern [persons that] it had in the first century." It was also, he thought, too patriarchal: "One of the dangers of this [shepherd] symbol," he writes, is that "it can subtly but powerfully convey the idea of the superiority of the pastor over [the] 'sheep."'7

\footnotetext{
${ }^{4}$ Sebastian Moore, The Fire and the Rose Are One (New York: Seabury), 11, 15.

${ }^{5}$ McDargh, 226.

${ }^{6}$ Seward Hiltner, Preface to Pastoral Theology (Nashville: Abingdon, 1958), 19, 68.

${ }^{7}$ Carroll A. Wise, The Meaning of Pastoral Care (New York: Harper \& Row, 1966), 2.
} 
In 1981, the Scottish ethicist Alastair V. Campbell charged not that Hiltner's shepherd was too hard or patriarchal, as Wise had argued, but to the contrary, too soft and solicitous: "We are forced to conclude," Campbell writes, "that in Hiltner the image [of the shepherd] is little more than a cipher which gives a religious appearance to statements about [pastoral] care derived from quite other sources, notably the faith statements of Rogerian counseling theory." $\mathrm{A}$ decade later, Jeanne Stevenson Moessner, today a pastoral theologian at Perkins School of Theology, wrote that "a paradigm other than that of the good shepherd, one with less inherent danger of lone external hierarchical authority, is crucial for the pastoral care of women. [Women] seek a paradigm that avoids the risk of the lone shepherd who can control, cajole, and cavort with the sheep."

Such critiques have only solidified in more recent years, not entirely without justification but swelling today to a clarion call among pastoral theologians to forgo emphasis on the lone shepherd and one lost sheep in order to attend instead to the larger community and contextual settings of ministry in a pluralistic world. ${ }^{10}$ Despite its historical prominence in constituting pastoral theology as a distinctive academic discipline, the parable of the shepherd and the one lost sheep fell on hard times almost from the start and has never fully recovered-a parable too dated, too rural, too hard, too soft, too hierarchical, too clerical, too individualistic, too Rogerian even, too fill-in-the-blank for guiding our understanding and practices of contemporary faith or ministry.

\section{Swimming in a Sea of Faith}

We're cautioned on the use of this parable from beyond the ranks of pastoral theology as well. Stanley Hauerwas, in recent comments on the Gospel of Matthew's version of the parable (Mt. 18:12-14), warns that "the parable of the lost sheep is not about us. ..." Hauerwas appears to contradict himself in the very same sentence, however, by insisting that the parable is instead "about God's unrelenting love of Israel and those called to be disciples of God's own' son" (emphasis added). ${ }^{11}$ But might not we hope to include ourselves among this

\footnotetext{
${ }^{8}$ Alastair V. Campbell, Rediscovering Pastoral Care (Philadelphia: Westminster, 1981), 42. "Jeanne Stevenson Moessner, "A New Pastoral Paradigm and Practice," in Women in Travail and Transition: A New Pastoral Care, M. Glaz and J. S. Moessner, eds. (Minneapolis: Fortress, 1991), 201, 198-211.

${ }^{10}$ Nancy J. Ramsay, ed., Pastoral Care and Counseling: Redefining the Paradigms (Nashville: Abingdon, 2004).

"Stanley Hauerwas, Matthew: Brazos Theological Commentary on the Bible (Grand Rapids: Baker/Brazos Press, 2006), 164.
} 
latter group of disciples, therefore making the parable somehow about us, at least in the sense that God's unrelenting love is about us or affects us?

In his thick new commentary on the parables Stories with Intent, Klyne Snodgrass counsels us against allegorizing or playing "Who's who?" in this parable. "Should the shepherd be identified with God, Jesus, the disciples, or someone seeking the kingdom?" he asks. "And especially, does the parable have christological implications?" (emphasis in original). ${ }^{12}$ In response to such questions, he writes:

[T]heological allegorizing is out of bounds, but parables generally, and this one specifically, do teach theology. Otherwise they would be useless. ... This parable is not saying that God is a shepherd. ... [Instead,] the actions and attitudes portrayed — not the people themselves-mirror the actions and attitude of God. ... The shepherd is not God, Jesus, or anyone else, and the sheep is not a person or group. These figures reside in and stay in the story. Certainly the ... wilderness and the friends do not "stand for something." At the same time, images selected for stories are not chosen at random; they are specifically chosen to set off resonances, and reference to a shepherd and sheep would bring to mind the OT use of these images for God, leaders, and hope for God's people. ${ }^{13}$

The line that Snodgrass is asking us to walk here is a thin one-against allegorizing and speculating about particular characters but in support of searching out theological meaning, relevance, and human resonance.

But he and other experts invariably and, in my view, inevitably walk this fine line only fitfully, unevenly. Joel B. Green, for example, agrees that the parable is "fundamentally about God, [its] aim to lay bare the nature of the divine response to the recovery of the lost," and Green's convincing reading here would seem to pass the test as an appropriate search for theological meaning and relevance. But Green is equally comfortable saying that Jesus is asking "his audience to identify with a shepherd" or with referring to the "toll collectors and sinners" with whom Jesus eats as the parable's lost sheep..$^{14}$

All of this is to say that while proceeding with caution is in order in our interpretation and use of this or any biblical image or text-none of us aspires

\footnotetext{
${ }^{12}$ Klyne Snodgrass, Stories with Intent: A Comprehensive Guide to the Parables of Jesus (Grand Rapids: Wm. B. Eerdmans, 2008), 106.

${ }^{13}$ Ibid., 107.

${ }^{14}$ Joel B. Green, The Gospel of Luke (Grand Rapids: Wm. B. Eerdmans, 1997), 574, 569.
} 
to be charged with promoting lone external hierarchical authority or with cavorting with sheep in ministry, nor with inserting oneself narcissistically into the biblical text in exegesis-it is always also the case that all of our words about God, even at their most abstract or esoteric or philosophical, and even the Bible's own words, are inevitably also words about us; they cannot not be about us, specifically because they are always our words, necessarily human words employing human languages to pose human questions at some level about whether God has regard for us, about whether you and I are a source of delight to the source of our delight.

All theologians must read and write and say their words about God, including my words to you tonight, without assurance that any is airtight or foolproof or the last word. We can only hope that God is more touched and amused than irritated by them. If at Princeton Seminary we are especially vulnerable to finding ourselves lost and are even more confused than we seem, this may be because we are trying to learn to live here without absolute foundations for the things of which we speak. There are simply no unassailable guarantees for our sorts of interests and concerns. We swim here instead in the deep end of the pool, trying to keep afloat in a sea of faith. ${ }^{15}$ Every word about God is a human word. Every parable about God is a parable about us, about you and me.

It's not uncontroversial, even to me, to nominate this too rural, too hard, too soft, too individualistic, too whatever parable as the most important word about God-and therefore about ourselves - that we could say to ourselves and to one another in the years we are privileged to share here together. But at those not infrequent moments when you find yourself wondering on what planet you've landed when finding yourself lost on Planet Princeton, I would covet your clinging to the mere eighty-nine words (in the Greek) that constitute this parable-memorizing them, tattooing them on some discreet body part, saying them to yourself over and over again- "Which one of you, having a hundred sheep and losing one of them, does not leave the ninety-nine in the wilderness and go after the one that is lost until he finds it? When he has found it, he lays it on his shoulders and rejoices. And when he comes home, he calls together his friends and neighbors, saying to them, 'Rejoice with me, for I have found my sheep that was lost'" —-saying these words about God and about us again and again as a way to restore your equilibrium and reclaim your confidence, like

\footnotetext{
${ }^{15} \mathrm{Cf}$. Dale B. Martin, Sex and The Single Savior: Gender and Sexuality in Biblical Interpretation (Louisville: Westminster John Knox, 2006), 181-85; Robert C. Dykstra, Alan Hugh Cole, and Donald Capps, Losers, Loners, and Rebels: The Spiritual Struggles of Boys (Louisville: Westminster John Knox, 2007), 69-70.
} 
the Dinky, as the little engine that could; remembering again and again Jesus's story of the searching shepherd and one lost sheep just may, like the Wawa, help get you through the night.

\section{URBANE SHEPHERDS}

Granted, it's a rural parable. Having come myself, however, from rural roots but by now somewhat adept at faking urbanity, I can tell you that rural and urban (and urbane) people share many things in common-among them a sense that they're all similarly different, all plenty complex, and even more confused than they seem.

Consider, for example, the best-known shepherds in recent memory, who, though fictional and living in an era and region of the country that inexorably consigned their story to tragedy, managed to catch up the rest of the nation and much of the world in their plight. I'm thinking, of course, of Ennis Del Mar and Jack Twist, those young Wyoming shepherds finding themselves lost on Brokeback Mountain in the summer of 1963. Brought to life by Annie Proulx in her short story in the New Yorker in 1997, ${ }^{16}$ a prophetic full year before that other Wyoming Shepard's-Matthew Shepard's - murder there, and later by the Ang Lee film, ${ }^{17}$ Jack and Ennis found that after a night on the mountain sharing a bedroll for warmth, they, in Proulx's understated words, "deepened their intimacy considerably." 18 The story unfolds as their lives and loves unravel for another twenty years, mostly apart from one another but sometimes reunited in the mountains, until near the fateful end when Jack cries out in anguish, "You're too much for me, Ennis. ... I wish I knew how to quit you." As it turns out, some thugs with a tire iron help him find a way. ${ }^{19}$

Too rural for the modern mind and church, the shepherd and one lost sheep? Given recent disputes within the church, the artistry and tragedy of Proulx's and Lee's shepherds somehow suggest a vocation remarkably current and suitably complex for shaping our discourse about God.

\footnotetext{
${ }^{16}$ Annie Proulx, "Brokeback Mountain," in Close Range: Wyoming Stories (New York: Scribner, 2003), 253-85.

${ }^{17}$ Ang Lee, director, Brokeback Mountain (motion picture; United States: Universal Studios, 2005).

${ }^{18}$ Proulx, 261.

${ }^{19}$ Ibid., 268.
} 


\section{The Shepherd is the SHeEP}

What, then, of charges that this parable can "subtly but powerfully convey the idea of the superiority of the pastor over [the] sheep," ${ }^{20}$ or that it dangerously promotes "lone external hierarchical authority"? 21 These indictments, if sustained, would provide reason enough for rejecting pastoral imagery for informing Christian ministry and faith. But I find inculcated here no such attitude of superiority or hierarchy. To the contrary, the shepherd and sheep in Jesus's parable appear to share a similar lot and unenviable plight. Both are bewildered creatures of low status, if not overtly despised then at least marginalized and ignored - with shepherding considered a vile and religiously forbidden profession in Jesus's day ${ }^{22}$ and, from what I hear, little esteemed even today - and both finding themselves in a predicament not of their own choosing. However righteous the shepherd, I hear flying all manner of expletives in this parable. Sheep and shepherd alike, and not just in the sexual ambiguity they share (for sheep, it turns out, like Jack and Ennis, are famously ambisexual ${ }^{23}$ ), are multifaceted beings all too familiar with finding themselves lost. As rural and urban persons share a good deal in common, so, too, to my mind, do shepherd and sheep.

This prospect becomes especially clear to me in a pastoral sense in another parable of sorts about another shepherd, this one nonfictional, who though counting millions among his flock remained singularly attentive to the importance of the one, who seemed always to identify with the one-a shepherd viscerally attuned to the only serious form of the religious question today, "Does God have regard for me?"

The shepherd is Mister Rogers, Fred Rogers, of the children's television program Mister Rogers 'Neighborhood. Mister Rogers, you may recall, was a Presbyterian minister who, along with Martin Luther King Jr., likely comes closest to having attained the status of Protestant sainthood in this country. Last Saturday on Weekend Edition, National Public Radio host Diane Rehm, ${ }^{24}$

\footnotetext{
${ }^{20}$ Wise, 2.

${ }^{21}$ Moessner, 201.

22 Joachim Jeremias, Jerusalem in the Time of Jesus (Philadelphia: Fortress, 1969), 302-12; Bernard Brandon Scott, Hear Then the Parable: A Commentary on the Parables of Jesus (Minneapolis: Fortress, 1989), 405, 413; Barbara E. Reid, Parables for Preachers: The Gospel of Luke, Year C (Collegeville: Liturgical Press, 2000), 184.

${ }^{23}$ Robert C. Dykstra, "Subversive Friendship," Pastoral Psychology, 58, 5/6 (2009): 579-601; Joan Roughgarden, Evolution's Rainbow: Diversity, Gender, and Sexuality in Nature and People (Berkeley: University of California Press, 2004).

${ }^{24}$ Diane Rehm, "30 Years of the Unexpected," Weekend Edition, September 12, 2009. National Public Radio online archives, accessed September 13, 2009. http:/www.npr.org/templates/ story/story.php?storyId=112758776.
} 
reflecting on her thirty years of conducting NPR interviews with "Nobel laureates and novelists, Supreme Court Justices and presidential candidates," said that "one interview will always stay with her: "I'll never forget talking with Mister Rogers," she said of her time with him just three months before his death in 2003. Others who interviewed him expressed similar sentiments. ${ }^{25}$

In a profile of Mister Rogers published in Esquire magazine in 1998, journalist Tom Junod describes a visit by Mister Rogers, who lived in Pittsburgh, to a fourteen-year-old boy who lived in California. The boy was born with a severe form of cerebral palsy, a disorder of the brain that interferes not with thinking but sometimes with walking and even talking. The boy had been abused as a child by caretakers who led him to believe that he himself was responsible for his illness. Now, as a teenager, Junod writes, the boy "would get so mad at himself that he would hit himself, hard, with his own fists and tell his mother, on the computer he used for a mouth, that he didn't want to live anymore, for he was sure that God didn't like what was inside him any more than he did." 26

But the boy had always loved Mister Rogers and even at fourteen "watched the Neighborhood whenever it was on." The boy's mother, in fact, believed that it was Mister Rogers who was keeping her son alive. She wished that her son could meet him in person-though, since they lived across the country and the severity of her son's disability prevented him from traveling, she assumed this would never happen. But then she "learned through a special foundation designed to help children like her son that Mister Rogers was coming to California and that after he visited a gorilla named Koko, he was coming to meet her son." Junod writes:

At first, the boy was made very nervous by the thought that Mister Rogers was visiting him. He was so nervous, in fact, that when Mister Rogers did visit, he got mad at himself and began hating himself and hitting himself, and his mother had to take him to another room and talk to him. Mister Rogers didn't leave, though. He wanted something from the boy, and Mister Rogers never leaves when he wants something from somebody. He just waited patiently; and when the boy came back, Mister Rogers talked to him, and then he made his request. He said, "I would like you to do something for me. Would you do something for me?" On

\footnotetext{
${ }^{25}$ Tim Madigan, I'm Proud of You: My Friendship with Fred Rogers (New York: Gotham/ Penguin, 2006).

${ }^{26}$ Tom Junod, "Can You Say ... 'Hero'?" Esquire 130, 5 (November 1998): 1432 (8 pp). Retrieved from Academic Search Premier database.
} 
his computer, the boy answered yes, of course, he would do anything for Mister Rogers, so then Mister Rogers said, "I would like you to pray for me. Will you pray for me?" And now the boy didn't know how to respond. He was thunderstruck. Thunderstruck means that you can't talk, because something has happened that's as sudden and miraculous and maybe as scary as a bolt of lightning, and all you can do is listen to the rumble. The boy was thunderstruck because nobody had ever asked him for something like that, ever. The boy had always been prayed for. The boy had always been the object of prayer, and now he was being asked to pray for Mister Rogers, and although at first he didn't know if he could do it, he said he would, he said he'd try, and ever since then he keeps Mister Rogers in his prayers and doesn't talk about wanting to die anymore, because he figures Mister Rogers is close to God, and if Mister Rogers likes him, that must mean that God likes him, too. ${ }^{27}$

The journalist, shadowing Mister Rogers for the magazine profile, said that when he heard about this story he complimented Mister Rogers "for being so smart-for knowing that asking the boy for his prayers would make the boy feel better about himself," which of course it must have done. But Mister Rogers, Junod writes, "responded by looking at me first with puzzlement and then with surprise. 'Oh, heavens no, Tom! I didn't ask him for his prayers for him; I asked for me. I asked him because I think that anyone who has gone through challenges like that must be very close to God. I asked him because I wanted his intercession."' 28

Who in this encounter is shepherd? Who is sheep? We're pretty sure we know as the story opens, but by the end it's not altogether clear. Who is shepherd? Who is sheep? Mr. Rogers is. The fourteen-year-old boy is. His mother is, too. You are. I am. Even Jesus, the teller of his shepherding tale: "You, Lord, are both Lamb and Shepherd./You, Lord, are both prince and slave," ${ }^{29}$ we sang hauntingly a few moments ago-the Lamb of God who takes away the sins of the world, the Shepherd of the flock who searches out the one and lifts meager odds that God has regard for us.

To be sure, Mister Rogers, the boy, his mother, and a host of others involved in making provision behind the scenes each play a distinctive role in this meeting;

\footnotetext{
${ }^{27}$ Ibid.

${ }^{28}$ Ibid.

${ }^{29}$ Sylvia G. Dunstan, "You, Lord, Are Both Lamb and Shepherd," copyright 1991, by GIA Publications, Inc.
} 
each has a different task to perform. The shepherd and the sheep here, to borrow some comments of Erik H. Erikson on Luke 15, "can find themselves and one another only by gaining their own identity in the very fulfillment of their intergenerational roles. ${ }^{\prime 30}$ Equally apparent, however, is that we discover in Mister Rogers's solicitous wisdom and the boy's audacious faith a shared yearning, a singular complexity, an impossible vocation, a familiar confusion. How often as faculty we are aware of finding in our students not just our spiritual but, more disconcerting, our intellectual superiors (though, as Erikson helpfully clarifies, we faculty still get to assign the grades).

Far from exhibiting a dangerous form of lone external hierarchical authority, Mister Rogers's plea for the boy's intercession makes me think that, however important our differentiated roles, we shepherds and we sheep share much in common here in the Neighborhood, here on Brokeback Mountain, here on Planet Princeton, here in the Kingdom of God. In attending when we can and must to the one over the many - to the individual, to the particular, to the singular, to the lost, to the special, to the marginal in the other and in ourselves - we discover not superiority and hierarchy but our only hope for mutuality without coercion.

\section{What Is Most Personal Is Most General}

In perhaps the best-known autobiographical essay from his book On Becoming a Person, another distinguished Mr. Rogers, this one Carl R. Rogers, who, despite the disparagement by Alastair V. Campbell ${ }^{31}$ noted earlier, became the most influential psychotherapist of the twentieth century, reflects on his most important lessons from life. Rogers writes:

Somewhere here I want to bring in a learning which has been most rewarding, because it makes me feel so deeply akin to others. I can word it this way. What is most personal is most general. There have been times when in talking with students or staff, or in my writing, I have expressed myself in ways so personal that I have felt I was expressing an attitude which it was probable no one else could understand, because it was so uniquely my own. ... In these instances I have almost invariably found that the very feeling which has seemed to me most private, most personal, and hence most incomprehensible by others, has turned out to be an expression for which there is a resonance in many other

\footnotetext{
${ }^{30}$ Erik Homburger Erikson, "The Galilean Sayings and the Sense of 'I,"' Yale Review, 70 (1981): 356, 321-62.

${ }^{31}$ Alistair V. Campbell, 1981.
} 
people. It has led me to believe that what is most personal and unique in each one of us is probably the very element which would, if it were shared or expressed, speak most deeply to others. This has helped me to understand artists and poets as people who have dared to express the unique in themselves. ${ }^{32}$

Artists, poets, and, wouldn't we aspire to add, theologians, too? People who have dared to express the unique in themselves not as a way to avoid community or context, not in order to live in isolation in the backwoods of Idaho, but to feel deeply akin to others, to beautify and beatify community and context, to build and encourage and delight in it?

What is personal is most general. Despite all those words over in the seminary libraries, not everything about God that can be said has been said, for the world still awaits your truths, your parables, your experiences of searching for, and being found by, our living Lord; the lyrical voice of the one still needs to be heard amid the chorus of the many. No shepherd besides you can think those thoughts; no sheep but you can bleat those words. That's because, as I heard psychotherapist Bill O'Hanlon quip, "You are unique, just like everyone else."."33

Students and faculty, finding themselves lost in confusion and grief, spontaneously gathered in this room on the morning of September 11, 2001, on hearing of the attacks on New York City and Washington, even as they had spontaneously gathered in this same room on that Holy Saturday in April of 1865 on hearing of the death of Abraham Lincoln. So now it is our turn to gather here, even more confused than we seem, rural and urbane, shepherds and sheep, searching and hoping to find, lost and hoping to be found.

${ }^{32}$ Carl R. Rogers, On Becoming a Person: A Therapist's View of Psychotherapy (Boston: Houghton Mifflin, 1961), 26.

${ }^{33}$ Bill O'Hanlon, "Working with Difficult Clients," a lecture delivered at the Psychotherapy Networker Conference, Washington, DC, March 26, 2009. 


\title{
Baccalaureate Sermon
}

\section{Tracks of My Tears}

by Luke A. Powery

\section{Revelation 5}

The Rev. Dr. Luke A. Powery is Perry and Georgia Engle Assistant Professor of Homiletics at Princeton Theological Seminary. He delivered this sermon at the baccalaureate service, on May 22, 2009, in Miller Chapel.

\begin{abstract}
$A$ s far as I can tell, this isn't a Pentecostal crowd. But today and tomorrow are two good days to say "hallelujah." Praise God. Hallelujah. I know that might not have been on your lips much during the last three years in seminary. Other words might have been tied to your tongue or memorized in your mind. But "hallelujah" is an appropriate theological term to nurture a life of praise. Ironically, though, as Walter Brueggemann notes, pain is "the matrix of praise." That means that to get to "hallelujah," one must really go through hell first. Now that's perhaps a more appropriate term for some to describe their seminary experience-hell. Maybe that's why seminaries are known as cemeteries. That first year, in the old curriculum--OT101, NT101, CH101, TH101, SC101killed you, to such an extent that the Apostles Creed took on new meaning for you because you suffered under Princeton Seminary, were crucified, dead, and buried, and then you descended into hell. Maybe it wasn't that bad, but I bet you shed some tears along the way. I see some tears today, too, but with tears, sometimes it's hard to tell if they are tears of joy or tears of sorrow.
\end{abstract}

But one thing is for sure, in the words of the hymn "Lift Every Voice and Sing," "[You] have come over a way that with tears has been watered." Tears have moistened the soil of your vocational journey. For some, you have lived the

\footnotetext{
'Walter Brueggemann, Israel's Praise: Doxology against Idolatry and Ideology (Philadelphia: Fortress Press, 1988), 136.

${ }^{2}$ See "Lift Every Voice and Sing," African American Heritage Hymnal (Chicago: GIA Publications, 2001), 540 .
} 
words of Augustine, who tells of how his tears flowed so freely that they made a "pillow for [his] heart." ${ }^{\text {"3 }}$ For others, it may be more like the psalmist who ate his tears in Mackay for breakfast, lunch, and dinner: my "tears have been my food day and night." That's not to say anything about the food in Mackay.

John is drinking his tears as they flood his life. He's drenched. He's baptized in tears of desperation. The pages of this passage are damp with the water of sorrow. If we look at John's canonical face close enough, we will see the tracks of his tears. I learned that notion from the great musical Motown theologian, Smokey Robinson, on this year's American Idol. "So take a good look at my face, you'll see my smile looks out of place, if you look closer, it's easy to trace the tracks of my tears." Smokey spoke about the meaning behind this song. He said that if you looked at someone's face close enough, you could see the tracks left behind by their tears because they had cried so much. I know some have laughed to keep from crying, but if I were a turn-to-your-neighbor kind of preacher, and I'm not, and if you looked closely at your neighbor's face, I'm sure you would see the tracks of some tears.

John has cried so much that you can see his tracks, even from far away, through the binoculars of biblical history. That's not sweat on his face. Those are tears. I can almost hear his crying turning into moaning. At first glance, we might think John is in his first year of seminary, because he's weeping bitterly, but he's weeping because he meets his own finitude and powerlessness. His tears are a fatalistic flood of lost hope, not because of a seminary experience, but because he can't see the future. It's unknown. Sound familiar? John weeps bitterly because he doesn't have power over his own future. He can barely go on with life as it is because his future is out of his hands. Every teardrop represents human weakness, so there he is drowning in this pool of agony and uncertain reality.

John understands human limitations and frailty because "no one in heaven or on earth or under the earth was able to open the scroll or to look into it." The scroll was the book of destiny about God's will. The scroll was God's final plan for the world. The scroll represents God's future for us, and no one could open these pages about the future of human history. No one could sneak a peek into God's plan. No one, nowhere. Not Oprah Winfrey or Barack Obama or Bill Gates or Martha Stewart or Donald Trump or Simon Cowell or Paula Abdul or Beyoncé or P. Diddy or your daddy or mommy, husband or wife, son or daughter. No one, nowhere. Not Calvin,

\footnotetext{
${ }^{3}$ Saint Augustine, Confessions Book IX, 12 (ca. 397-98; reprint, trans. R. S. Pine-Coffin, New York: Penguin, 1961), 202.

${ }^{4}$ See Psalm 42:3.

${ }^{5}$ For the entire set of lyrics of "Tracks of My Tears," see http://www.metrolyrics.com/ the-tracks-of-my-tears-lyrics-smokey-robinson.html [accessed October 30, 2009].
} 
Luther, Barth, King, Cone, or Cannon will help either. Not even Wall Street. The U.S. government can't bail John out, because they can't even see into the future! No one knows what is to come. John is trapped in wet chains of fear and hopelessness.

And we should be weeping right along with John, not because of fear of the unknown, but because we have fooled ourselves into thinking we can save ourselves and the world, even after seminary. All of that talk about God has made some of us think we are god. When the mighty angel asks, "Who is worthy to open the scroll and break its seals?" We raise our hands to be first in line. We clothe ourselves in the garments of academic credentials or in the garb of howmany-things-I' $m$-doing-for-Jesus or in the PTS clothes of self-assurance or in the cloak of a theological or political camp. I'm this or I'm that. I'm leading this, doing that, teaching this, and helping with that. We soon forget who really has the power, who really is in control, who really is in charge, who really is Lord. "No one in heaven or on earth or under the earth was able to open the scroll or to look into it." But we still build our human thrones, thinking we have the power. Building our thrones, those symbols of the center of the cosmos, making ourselves the center of an ecclesial universe. Our thrones grow second by second, minute by minute, as if to change the words of that hymn and sing, "Immortal, invisible, I'm only wise." Not what I can do for the church but what the church can do for me. "Crown me with many crowns." "No wonder John is weeping as he sets his tearful gaze on us out of the pages of scripture and still says there is "no one."

John's weeping, because if we continue on this prideful path, we will dig our own graves to nowhere but down. John has good reasons to weep if all there is, is human finite power. He has good reasons to weep if we are in control. He has good reasons to weep if all there is, is us. We might as well throw in the theological towel if we are in charge, if we have ultimate power, if we hold the future, if that's what we're teaching in our classrooms and churches. John has good reasons to weep at our selfdeception, at our thinking we have the power to make a better future. We don't even have the power to make a better present. John weeps until his eyes, blinded by despair, are made to see who really has the power over our future, and what he sees may surprise us. It's not Mary's pretty little lamb whose fleece was white as snow, but a Lamb whose fleece is red with blood for you and me. His shed tears cannot compare with the shed blood of a lamb. John realizes then, in the words of James Weldon Johnson, that "we have come, treading a path through the blood of the slaughtered."

\footnotetext{
${ }^{6}$ For the actual words of this hymn reference, see "Immortal, Invisible, God Only Wise," The Presbyterian Hymnal (Louisville: Westminster John Knox Press, 1990), 263.

7 For this hymn reference, see "Crown Him with Many Crowns," The Presbyterian Hymnal, 151.

8 "Lift Every Voice and Sing," African American Heritage Hymnal, 540.
} 
A Lamb standing as if it had been slaughtered. A lame Lamb? Where are the prosperity gospel gurus now? A lame Lamb? Where are those who want to bleach Christ squeaky clean? A lame Lamb? Where are those who want to praise without acknowledging pain? A lame Lamb. Mary's crucified Lamb of God, Jesus Christ. Broken, bruised, beat down for us. "Nothing in his appearance that we should desire him ... like a sheep that before its shearers is silent." "9 Slaughtered but still standing. This weak-looking lamb has the power, all power in his nail-pierced hands. He is worthy, able, and authorized to open the scroll of the future and its seven seals. He holds the future in his hands. God's future for us. There is a future, and this future is not closed. There is a hope John never fully realized until he sees the One who has the scroll in his hands. The slaughtered-standing Lamb has the power. The power to help our economic situation, the power to help our healthcare system, the power to help our educational system, the power to help our governmental system, the power to help even our seminary system, the power to give us a future, the power to make all things new and the power to make all things right. I've got the power?! No. He's got the power! Wonder-working power in the blood of the Lamb!

Once the Lamb shows up, the pages of this pericope dry up John's tears but are then stained with blood. Our future is costly, so there is no room for cheap praise, for as Gordon Lathrop reminds us, "The grounds of our thanksgiving are found in a crucified man." 10 The presence of the crucified Lamb changes John's existential melodic key from minor to major. There's a new song beginning to bubble within his soul. Do you hear what I hear? When the Lamb "went and took the scroll from the right hand of the one who was seated on the throne," then the praise party begins, the musical melodies of the harp begin to be plucked, the aromatic prayers of the saints start going up, and then my favorite part begins-singing, full-voiced singing of a real Hallelujah chorus. There is really no other appropriate response to the realization that the Lamb holds our future securely in his hands. The Lamb is the fulcrum of our future. John's tears didn't drop in vain, for every teardrop was an epiclesis for God to intervene. John discovers that they who sow in tears will reap with joy. Weeping may endure for the night, but joy comes in the morning. And with joy comes much singing. John is singing now in the celestial chorus of the Crucified One. Do you hear what I hear?

There is our wounded song leader, our saving maestro himself, with his slaughtered stance, in the center of this chorus, leading us in a victory chant. Holding

\footnotetext{
${ }^{9}$ See Isaiah 53:2, 7 .

${ }^{10}$ Gordon Lathrop, Holy Things: A Liturgical Theology (Minneapolis: Fortress Press, 1998), 58.
} 
the scroll, leading us in this "scrollful" song. I see that scroll becoming a bloodstained baton, directing us in our primary doxological vocation. And with every wave of his baton, the singing gets louder, and the choir grows in number. With each wave, he wipes every tear from every eye. "Death will be no more, mourning and crying and pain will be no more."11 His only instruction is "do not weep." No more weeping, John. Just lots of full-voiced singing, because we know who holds the future. Do you hear what I hear? A beautiful heavenly choir of living creatures and elders who sing in harmonious hymnic counterpoint, "You are worthy to take the scroll and to open its seals, for you were slaughtered and by your blood you ransomed for God saints ... you have made them to be a kingdom and priests serving our God." This was spontaneous, this new song they never rehearsed, but they sang it in tune. They never sang it before, but it sure felt right. It was a song of freedom, their Deliverer had come.

Through a kingly sacrificial Lamb, freedom comes. This is the song of the redeemed, not for a segregated spiritual click, but for the "saints from every tribe and language and people and nation." We might be surprised who's singing with us. No economy of exclusion there. No demonization of difference there. Those we thought shouldn't be there, those we didn't want to be there. Guess what?! They are there, God's diverse kingdom. The loosed chains of oppression and sin are stirring up every crack and crevice of society and every corner of heaven. We've been set free to sing! Do you hear what I hear? "I heard the voice of many angels surrounding the throne and the living creatures and the elders; they numbered myriads of myriads and thousands of thousands, singing with full voice, 'Worthy is the Lamb that was slaughtered to receive power and wealth and wisdom and might and honor and glory and blessing!"” This cosmic choir keeps growing into the thousands and keeps growing in volume. The loud, full-voiced singing can't stop, won't stop, because deliverance has come Christ-style. There's a whole new world. A whole new way of living. A future and a hope. A slain Lamb conquers. The last are now first. The least, the greatest. The slaves become kings. The poor become priests. This is the reason why we sing - the Lamb holds our future.

This might be bad news for some, because this song of redemption is also a song of resistance. I did my exegetical homework. It's not just a rap for God but it is, as scholar Brian Blount puts it, a "a rap against Rome,"12 the Roman emperors then and now, the imperialistic gods who oppress and depress. This ministry of song says up to God but down to other gods. The gods of a financial fiscal year

\footnotetext{
"See Revelation 21:4.

${ }^{12}$ Brian K. Blount, Can I Get a Witness? Reading Revelation through African American Culture (Louisville: Westminster John Knox Press, 2005). 91-118.
} 
who would say you don't have enough money to do your ministry anymore. The gods who would say your vocation is really a career, so you should just strive to be a big steeple preacher with little theology. The gods of profit rather than prophets of God. This song calls you to give voice against all the powers that would try to mute your voice-this is praise against the powers. I know it's not popular, or cute, but Christ is the musical conductor. This is a song you should have in your musical ministerial repertoire as you leave this place, because it declares the demise of the gods - the gods of racism, sexism, classism, and consumerism-will not prevail, because there is one slaughtered-standing Lamb who stands against the power for us, and the future is His. Sing the future now. Sing the future present. Not just in the shower but everywhere you go.

This sanctified song won't make it to the top of the billboard charts, but it's still contagious. You might not hear it right now, but it's beginning to rumble. This song can't be stopped, because there is a Power operating in the world that is greater than any human power. This song won't be stopped, because of the Lamb of God who takes away the sins of the world. He's got the scroll! Do you hear what I hear? I hear the heavens vibrating as others join in the holy refrain. The angels, the elders, the living creatures are fired up. In the prelude, there were lots of tears, but if you look at the tear-tracking system now, you will see that in the postlude, the stormy clouds of tears have given way to sunny doxological cheers. And if you listen closely, you will hear something beginning to rumble here too. I thought that this might be a "Presbycostal" crowd after all.

I hear John singing, but he's not alone. I hear Oprah Winfrey, Barack Obama, Bill Gates, Martha Stewart, Donald Trump, Simon Cowell, Paula Abdul, Beyoncé, P. Diddy, fathers, mothers, husbands, wives, sons, daughters, Calvin, Luther, Barth, King, Cone, Cannon, Wall Street, and even the U.S. government. No one is left out of this hymn sing. I hear Dan Migliore, Guy Hanson, Chuck Bartow, Don Capps, Abigail Evans, Randy Nichols, and all of us. I hear the birds in the air chirping. The cows in the field mooing. The dogs in the neighborhood barking. The cats down Nassau street meowing. "Every creature in heaven and on earth and under the earth and in the sea, all that is in them," singing not "me, myself, and I" but "To the one seated on the throne and to the Lamb be blessing and honor and glory and might forever and ever!" Amen! Amen! The future is God's-and don't you forget it! 


\section{Lectures}

\section{Africa's Hands: Pentecostalism and Independency}

by Allan Anderson

Allan Anderson is professor of Global Pentecostal Studies at the University of Birmingham, England. He delivered this lecture at Princeton Theological Seminary on December 1 and 2, 2008. The lecture borrows heavily from Anderson's Spreading Fires: The Missionary Nature of Early Pentecostalism (Maryknoll: Orbis, 2007); it was adapted for the Missions Lectures at PTS, abridged in some parts and substantially changed.

$T_{\text {ted }}$

\section{THE Rise OF AFRICAN INDEPENDENCY}

he decisive defeat of Italy by Ethiopia in 1896 at the battle of Adowa had profound significance for educated Africans, including church leaders. For them it represented the liberation of African peoples from colonial oppression. The political and religious ferment that was taking place in Africa created serious tensions and instability across the continent by the beginning of the twentieth century. This was a stimulus for increasing European involvement and the growth of both European and North American Christian missions and independent African churches. European settlers were seeking to appropriate vast areas of African land for themselves, to exploit Africa's rich natural resources for their expanding industries, and to control cheap African labor for their own advantage. The "scramble for Africa" resulted in most of Africa being carved up by France, Britain, and Portugal at the Conference of Berlin, held in 1884-1885; Belgium, Germany, Spain, and Italy also received large parcels of land. ${ }^{1}$ Only Abyssinia (Ethiopia) was left independent, and Liberia was already a quasi-independent state ruled by descendants of former African American slaves. This was the context that greeted Pentecostal missionaries in Africa. Africans themselves stood by helplessly, or when they resisted, as they sometimes did, they were easily

'Richard Overy, ed., The Times History of the World, New Edition (London: Times Books, 1999), 240-41. 
defeated by the superior weaponry, technology, and political determination they lacked and by the divide-and-rule strategy of the colonizers. Of course, although the Europeans won the battles, they could not win the war, and despite harsh repression, African resistance was never entirely subdued.

The so-called Ethiopian and African independent church secessions in South Africa and Nigeria from the 1880s onward set a pattern for the next century. The term Ethiopian, which was used to refer to some of these churches, came from the ideology set down in Psalm 68:31: "Ethiopia (read "Africa") shall stretch out her hands unto God." For many Africans the name Ethiopia represented the proud and independent Africa that had received Christianity centuries before the colonizing Europeans. Although the text had been stripped of this ideological meaning, evangelical missionaries were well aware of it. They quoted the psalm far and wide, especially when they found responsive audiences that seemed to confirm its message. Missionary writers often cited this passage as well as the passage referring to Simon of Cyrene carrying Jesus' cross as symbols of Africa's humiliation and slavery. On the other hand, the conversion of the Ethiopian eunuch was a symbol of Africa's exaltation, evidence of God's plan for Africa to "stretch out her hands to God.".

Secession was not a peculiarly African phenomenon, as Africans were simply continuing what had become commonplace in European Protestantism. By the end of the nineteenth century there were already hundreds of new denominations, "faith missions," and other societies in the West that sent missionaries to Africa. The denominations and mission societies were reproduced here, and it is hardly surprising that it should be considered a natural thing for secessions to occur, urged on by the mission policies and colonial politics of the time that were highly prejudicial to Africans. As Adrian Hastings reminds us, although the Ethiopian and African churches were indeed reactions to the tight control of European missions, they were still a very small minority by 1910 and "still so closely controlled by a missionary model of religious life."3

Some of the new American and European missions from which African independent churches (AICs) emerged, such as the Zionists from Chicago, the Pentecostals, and the Faith Tabernacle from Philadelphia, were undergoing a process of fission, inherent in the ecclesiological structures of these groups. In fact, as

${ }^{2}$ Upper Room 1:3 (Aug 1909), 6; Latter Rain Evangel 2:11 (Aug 1910), 22; 2:12 (Sept 1910), 20; 5:7 (Apr 1913), 15; 6:2 (Nov 1913), 19; Bridegroom's Messenger 69 (1 Sept 1910), 2; 129 (15 Mar 1913), 1.

${ }^{3}$ Adrian Hastings, The Church in Africa 1450-1950 (Oxford: Clarendon, 1994), 499. 
Hastings points out, secession is endemic to Anglo-Saxon Protestantism, particularly after it ceased to be a state church. ${ }^{4}$ The result was considerable confusion, and because the new African Christians saw a multiplicity of denominations as the norm, they considered the creation of many new ones a natural consequence. ${ }^{5}$ Nevertheless, the African and Ethiopian churches were the ecclesiastical forerunners of the African nationalist movements for independence, and they sought to make Christianity more "African" and therefore more appealing and relevant. The Pentecostals added to the plethora of new independent denominations and churches being added to Africa's bewildering Christian landscape. Their particular independent ecclesiology, radical critique of "established" Christianity, and emphasis on the power of the Holy Spirit for all—regardless of educational or social accomplishments-led naturally to the creation of new independent movements. It is this relationship that I examine here.

The pressures of religious change that colonial Africa experienced at the end of the nineteenth century resulted in many resistance movements. The Ethiopian and African churches were not as much movements of religious reform and innovation as were the later "prophet-healing" churches, but they were primarily movements of political protest and expressions of resistance against European hegemony in the church. Although they rejected the political dominance of white-led churches, they framed their protest in familiar Protestant categories and therefore did not seriously contest its social, religious, and cultural components. ${ }^{6}$ Their more lasting significance lay in the fact that they were the first to overtly challenge social structures of inequality and oppression in the church and to proffer a religious ideology for the dignity and self-reliance of the black person, thus foreshadowing the African nationalist movements and providing them with a religious justification. These secessions were often the result of tension between an increasingly self-aware African Christian community and a multiplying number of zealous European missionaries with colonial expansionist sympathies. The secessions that began in South Africa and Nigeria set a pattern for the next century.

In Nigeria there was also the particularly aggravating dimension of the perceived failure of Samuel Ajayi Crowther's Niger Mission. The result was that new, young, white missionaries were virtually unanimous in their opinion that Africans were unfit for church leadership - an opinion that was to persist for over half a century.

\footnotetext{
${ }^{4}$ Ibid., 498-99.

${ }^{5}$ Ibid., 527, 532-33.

${ }^{6}$ Jean Comaroff, Body of Power, Spirit of Resistance: The Culture and History of a South African People (Chicago: University of Chicago Press, 1985), 176.
} 
In 1890, the actions of young English missionaries forced Bishop Crowther to resign from the committee that he chaired. The elderly Crowther was humiliated and died a year later and was replaced by an English bishop. ${ }^{7}$ After 1890, the number of young European missionaries to Nigeria increased significantly, and this only increased the problem for the Africans. ${ }^{8}$ But there were even deeper religious and sociocultural issues at stake. The 1907 entrance of Pentecostalism into the African melting pot had the effect of stimulating new and more radically transforming types of independent churches. By the early twentieth century, the African and Ethiopian churches were overshadowed by new, rapidly growing prophethealing or "Spirit" churches-so named because of their emphasis on the power of the Spirit in healing, prophecy, and speaking in tongues.

The theory that AICs are primarily protest or resistance movements reacting to western missions and colonialism has some validity in the case of the first Ethiopian or African movements but is inadequate for a number of reasons. The first AICs were secessions from mission churches, but the theory does not explain the ongoing growth of AICs long after mission connections had been broken, nor does it account for the fact that the majority of AIC members have never had any mission church connection. ${ }^{9}$ According to M. L. Daneel, the main criticism made by Spirit-type AICs in Zimbabwe against mission churches was what they saw as the neglect of the Holy Spirit. ${ }^{10}$ The reaction-to-mission theory does not sufficiently recognize the creative and innovative endeavors of African missionaries in the AICs who crossed national and ethnic boundaries to proclaim a new message. Instead of being the objects of European missions who were reacting to that mission, AIC leaders were in fact the subjects of their own mission, actively involved in truly African mission initiatives. AICs were in a continuous rather than a discontinuous relationship with missionary churches because African prophets sought to reproduce what they believed to be important in missionary Christianity. The process was primarily one of conversion, not of secession. ${ }^{11}$ AICs introduced many innovations to Christianity that the European missionaries had been unable to introduce due to the confines of their western cultural paradigms.

The inability of the missionary message to be relevant to the daily struggles of African people, especially in the area of sickness and healing, created a vacuum

\footnotetext{
${ }^{7}$ Lamin Sanneh, West African Christianity: The Religious Impact (London: Hurst, 1983), 169. ${ }^{8}$ Sanneh, West African Christianity, 172; James B. Webster, The African Churches among the Yoruba 1888-1922 (Oxford: Clarendon, 1964), 17-21, 32-33, 40-41.

${ }_{9}^{9}$ M. L. Daneel, Quest for Belonging (Gweru: Mambo Press, 1987), 99-100.

${ }^{10}$ M. L. Daneel, Old and New in Southern Shona Independent Churches, vol. 2, (The Hague: Moulton, 1974), 28.

${ }^{11}$ Hastings, Church in Africa, 531.
} 
that was later filled by the prophetic and Pentecostal movements. This irrelevance also led to a profound disillusionment with the form of Christianity that Africans had embraced after forsaking their traditional religions. No solution was given to the problem of sickness. Even medical missions tended to secularize healing to the realm of western medical expertise that was beyond the sphere of religion. ${ }^{12}$ In African communities, however, religion could not be separated from the whole of life's experiences. Sickness and affliction were also religious experiences. Healing and protection from evil are the most prominent practices in the liturgy of churches of the Spirit and are probably the most important elements in their evangelism and church recruitment, especially in the early stages of their development. Traditional African communities were health-orientated communities, to a large extent, and in traditional African religions rituals for healing and protection played a prominent role. The independent Spirit churches both continued this tradition and imbued the familiar symbols with new meanings.

Like other Pentecostals, independent churches of the Spirit emphasize receiving a conscious experience of the Holy Spirit, practice healing and exorcism, insist on personal testimony, and function as a "protest movement" against what African writers have termed "the North Atlantic captivity of the Christian faith."13 A frican missionaries went out from these movements proclaiming that God not only "saves souls" but also heals physical affliction, delivers from oppressive forces and structures, and provides answers to felt human needs. ${ }^{14}$ South African theologian Simon Maimela remarked that the greatest attraction of AICs lay in their open invitation to Africans to bring their anxieties about witches, sorcerers, bad luck, poverty, illness, and other kinds of misfortune to church leaders. ${ }^{15}$ Pentecostalism's message of deliverance from sickness and from the oppression of evil spirits, and the message that the power of the Spirit could enable one to cope in a hostile spirit world were good news. This was a religion that offered solutions to all of life's problems, not only the so-called spiritual ones. ${ }^{16}$ In early twentieth century Africa these were movements of mass conversion, or African "revivals." 17 In particular, the Pentecostal AICs that have arisen all over Africa in the twentieth century have attributed their emergence to the work of the Holy Spirit.

\footnotetext{
${ }^{12}$ Hastings, Church in Africa, 530; Daneel, Quest, 78.

${ }^{13}$ Deji Ayegboyin and S. Ademola Ishola, African Indigenous Churches: An Historical Perspective (Lagos: Greater Heights Publications, 1997), 40-42.

${ }^{14}$ Allan Anderson, with Samuel Otwang, Tumelo: The Faith of African Pentecostals in South Africa (Pretoria: University of South Africa Press, 1993), 32.

${ }^{15}$ Simon S. Maimela. "Salvation in African Traditional Religions," Missionalia 13:2, 1985 (63-77), 71.

${ }^{16}$ Ayegboyin and Ishola, African Indigenous Churches, 24-25.

${ }^{17}$ Hastings, Church in Africa, 512, 530.
} 


\section{West African Revival Movements 1907-1930}

During the years 1907-1908, several Pentecostal missionaries arrived in different parts of Africa for the first time. One early group comprised African American missionaries who came to Liberia from the Azusa Street revival in Los Angeles. Liberia was a favorite destination for African American missionaries, who may have been encouraged by the contemporary movement advocating emigration to Africa. But these missionaries did not find Liberia an easy place to live in and soon returned to the United States. One factor that made Liberia difficult was the unrest among the native Liberians, especially in the Cape Palmas area in the southern corner of the country, where the Grebo people lived. An insurrection against the Liberian government that began in 1909 escalated into the full-scale Grebo War in $1910 .{ }^{18}$ And there was also extensive exploitation of indigenous Liberians by the Americo-Liberian minority, which lasted for much of the twentieth century. Slavery was outlawed there only in 1936, and aboriginal people were denied voting rights.

In December 1906, sixteen missionaries left New York for Liverpool: George and Daisy Batman and their three children; the Hutchins, McKinney, and F. M. Cook families; Mrs. Lee; and Mrs. Farrow, all of whom sailed on from Liverpool to Monrovia, Liberia. ${ }^{19}$ Once in Liberia, Mrs. Cook, Mrs. Lee, and the entire Batman family died of tropical fever within a few weeks. The Apostolic Faith did not announce their tragic deaths, which soon became a source of great embarrassment and criticism for the new movement ${ }^{20} \mathrm{Mrs}$. Farrow returned home after seven months in Johnsonville, Liberia, where she worked among the indigenous population, reporting that twenty had "received their Pentecost" and that she had been able to speak and preach two sermons in the Kru language. The newspaper concluded the report about her by saying that some of "the heathen" had spoken "in English and some in other tongues."21 Other early African American missionaries to Liberia were the Frank Cummings family, Church of God in Christ missionaries, who arrived in 1907, and Edward and Mollie McCauley, leaders of the mixed Apostolic Faith congregation of Long Beach,

\footnotetext{
${ }^{18}$ Gordon M. Haliburton, The Prophet Harris: A Study of an African Prophet and His Mass Movement in the Ivory Coast and the Gold Coast 1913-1915 (London: Longman, 1971), 28-35.

${ }^{19}$ Apostolic Faith 2 (Oct 1906), 1; Bridegroom's Messenger 118 (15 Sept 1912), 3; Confidence 5:11 (Nov 1912), 247; Cecil M. Robeck Jr., The Azusa Street Mission and Revival: The Birth of the Global Pentecostal Movement (Nashville: Thomas Nelson, 2006), 274.

${ }^{20}$ Robeck, Azusa Street, 269-70.

${ }^{21}$ Apostolic Faith 11 (Jan 1908), 2.
} 
California. With an associate, Rosa Harmon, the McCauleys arrived in Monrovia in November 1907 and established a thriving work there among Kru people. ${ }^{22}$

The establishment of a large Pentecostal mission in Liberia goes back to Canadian missionaries who arrived in Cape Palmas in December 1908. ${ }^{23}$ John Harrow and John and Jessie Perkins were formerly Methodist Episcopal missionaries, Harrow having first visited Liberia in 1894 under Bishop William Taylor. Perkins reported having sixty-six in the mission and of teams of preachers fanning out into the surrounding villages preaching against "ju-jus" (fetishes). ${ }^{24}$ By 1911 a team of ten Pentecostal missionaries was working in four stations, including a new station operated by William and Jennie Johnson, who had already been in Africa fifteen years. The mission concentrated on bringing converted individuals (especially young men) out of their towns and villages into the mission compound, teaching them to read and write, and then sending them back as preachers to their own people. In 1912, Harrow mentioned three "native workers" by name. These were Jasper Toe, who had first led Perkins to his home in the interior in 1908 and in 1914 took charge of a station, and Friday Sebo and John Aner, who went to their own people to start Pentecostal work. ${ }^{25}$ In 1918 Jasper Toe went as a missionary to the Gold Coast (Ghana), the first African leader to do so from this mission. He later became the first African superintendent of the Assemblies of God in Liberia. ${ }^{26}$ Altogether, ten missionaries in this mission died of tropical diseases in the first eight years of the mission, and some returned home. ${ }^{27}$ Conditions for these workers were far from easy. Johnson wrote of traveling "through forest and jungle, fording rivers and wading swamps until almost exhausted" in order to reach remote villages with the gospel. $\mathrm{He}$ also asked for prayer for his wife's nervousness over the "many snakes and rats, and insects of every kind" that she had to endure. ${ }^{28}$

\footnotetext{
${ }_{22}$ Apostolic Faith 13 (May 1908), 1; Confidence 2:4 (Apr 1909), 92; 7:2 (Feb 1914), 36; Upper Room 1:3 (Aug 1909), 7; Robeck, Azusa Street, 271-72.

${ }^{23}$ Confidence 1:9 (Dec 1908), 8; 2:4 (Apr 1909), 92; 2:8 (Aug 1909), 184; 2:9 (Sept 1909), 209.

${ }^{24}$ The word fetish is used here as West African Christians use it, to denote "ju-jus": traditional charms, images, 'medicines,' amulets, etc., used to ward off evil or to do someone else harm.

${ }^{25}$ Latter Rain Evangel 8:11 (Aug 1916), 20.

${ }^{26}$ Latter Rain Evangel 11:7 (Apr 1919), 13; http:/www.youtube.com/watch?v=q80Y4prXsPs, accessed 28 Nov 2008.

${ }_{27}$ Upper Room (Aug 1910), 6; Latter Rain Evangel 2:11 (Aug 1910), 21; 3:10 (July 1911), 17; 3:11 (Aug 1911), 17; 5:3 (Dec 1912), 12; 6:2 (Nov 1913), 2; 8:11 (Aug 1916), 18-21; Bridegroom 's Messenger 67 (1 Aug 1910), 4; 69 (1 Sept 1910), 2: 75 (1 Dec 1910), 3. 4; 79 (1 Feb 1911), 4; 81 (1 Mar 1911), 4; 104 (15 Feb 1912), 2; 106 (15 Mar 1912), 1, 3; 130 (1 Apr 1913), 4; Trust 10:1 (Mar 1911), 19; 10:2 (Apr 1911), 15-16; 11:8 (Oct 1912), 19; Confidence 6:2 (Feb 1913), 39; 6:9 (Sept 1913), 184; CE 55 (22 Aug 1914), 4.

${ }^{28}$ Latter Rain Evangel 5:6 (Mar 1913), 17; 6:2 (Nov 1913), 2-3; 6:10 (July 1914), 22-24; 8:1 (Oct 1915), 15; 9:6 (Mar 1917), 21-22: Trust 15:9 (Nov 1916), 24.
} 
In 1913, one of the most remarkable preachers in the history of Christianity began preaching in the French colony of Cote d'Ivoire and from there to the Gold Coast. William Wade Harris (1865-1929) was from the Cape Palmas area and Grebo, the areas most involved in the insurrections against the AmericoLiberian government. Raised and educated in a Grebo Methodist minister's house, Harris became a Methodist lay preacher who could speak English well, and he worked as a seaman, a bricklayer, an Episcopalian school teacher, and finally a government interpreter. He lost his job when he became involved in political activities and was imprisoned on a charge of treason. Following his mentor Edward Blyden, a former Liberian vice-president, Harris suggested that Liberia should become a British colony instead of being ruled oppressively by Americo-Liberian settlers. He was arrested in 1909 for allegedly pulling down the Liberian flag and planting the British flag in its place and for leading a Grebo uprising. After he had received the first of many visions in prison, he began to believe that his God-given mission was to be a prophet and to take God's word to those who had never heard it. To accomplish this, as he later told a French Protestant missionary, the Spirit came on him as on the Day of Pentecost and he spoke in tongues. ${ }^{29}$

There is the distinct possibility that Harris came in contact with and knew the Pentecostal missionaries working in his home area of Cape Palmas, especially because many of them were former Methodists. One of them, William Johnson, spoke of working with Kru people from a Methodist school, and John Perkins was also working in this area. ${ }^{30}$ It is also likely that Harris had heard of African American preachers of the Apostolic Faith Mission such as Edward McCauley, who had a thriving Kru Pentecostal congregation in Monrovia from 1908 until at least 1913. We may never know the extent of Harris's contact with Pentecostalism, but his personal experience of Pentecost was to signify a dramatic change in the direction of his life.

The date of Harris's release from prison is unknown, but it could have been as late as 1912 . When he emerged, it was with a calling to be a prophet preaching repentance and faith in Jesus Christ. He began walking east, to Côte d'Ivoire, and went as far as the western Gold Coast, a British colony at the time. He was one of the first, and certainly one of the most influential, African Christian prophets, and his preaching started an unprecedented movement of mass conversions to Christianity. He preached from the Bible about one true God, healing from disease, and the rejection of fetishes and practices associated with traditional religions. His

${ }^{29}$ Haliburton, Prophet Harris, 30-32, 35.

${ }^{30}$ Latter Rain Evangel 2:12 (Sept 1910), 16; Bridegroom 's Messenger 99 (1 Dec 1911), 1. 
practices had a precedent in the activities of the Pentecostal preachers in Liberia, where in 1911, William Johnson told of one of the African preachers in the Cape Palmas area whose main work seemed to have been to exhort people to "destroy their jujus or idols." "31 Going a step further by rejecting western clothing and walking barefoot, the white-bearded Harris preferred the long white calico robe of the northern West Africans, a round white turban, and black bands crossed around his chest. He carried a Bible, a gourd rattle, a bowl, and a staff in the shape of a cross, striking an imposing figure not unlike a biblical prophet. ${ }^{32}$ Harris was accompanied initially by two female assistants, who were also dressed in white. At this time, a few hundred Catholics were probably the only Christians throughout Côte d'Ivoire. The effect of Harris's ministry was electrifying. As Haliburton put it, "the whole population of the regions through which he passed accepted him as the authentic voice of God," and saw Harris as God's messenger "to revitalize their religion and society ... in a time of crisis." ${ }^{\text {" I3 }}$ It was estimated that within a year, 120,000 people accepted Harris's message, and he is regarded as the father of Ivorian Christianity. Harris was seen as a threat by the French colonial authorities and was arrested and deported back to Liberia in 1914. Harrist churches emerged only after Harris's death, in 1929.

A similar revival was led by the popular Anglican preacher in the Niger Delta Garrick Sokari Braide (c.1882-1918), formerly an Ijo fisherman and trader who had little formal education. He was the first of many Nigerians to be recognized as a Christian prophet and prayer-healing evangelist. His reputation grew, and from about 1912 until 1916 he emerged as a fiery preacher urging the destruction of shrines, the rejection of fetishes and alcohol, and healing through prayer. Like Wade Harris, his message was simple: renounce traditional practices and believe in God. He named his hometown Bakana-Israel, and multitudes flocked there and spread his message all over the Niger Delta. The chief beneficiaries of this mass conversion movement were Anglicans, but Braide's increasing popularity and exploits were regarded as a threat to both colonial authorities and Anglican missionaries. There is evidence that the area's alcohol trade decreased drastically as a result of Braide's preaching, and consequently, the colonial excise revenue fell. Braide, like Harris, advocated the use of African music in Christian worship with clapping and ecstatic dancing, and he encouraged the development of African leadership. On one occasion he was reported to have said publicly that the time had come for A fricans to assume responsibility for themselves, which was interpreted as anticolonial incitement.

\footnotetext{
${ }^{31}$ Latter Rain Evangel 3:12 (Sept. 1911), 13.

${ }^{32}$ Haliburton, Prophet Harris, 1.

${ }^{33}$ Haliburton, Prophet Harris, 38.
} 
In 1916, Anglican auxiliary bishop James Johnson, an African, who had confirmed Braide four years earlier, was asked by Braide's supporters to recognize his ministry. Instead, the bishop declared him a "devil-inspired" heretic and suspended any clergy supporting him. A month later the colonial authorities had Johnson's written encouragement to arrest Braide for seditious behavior, incitement to commit violence, and willful damage to property - in this case, traditional shrines. He spent most of the next two years in prison and died after his release in 1918, perhaps as a result of the influenza epidemic. Although Braide remained a faithful Anglican until his death, some 43,000 of his followers formed the Christ Army Church, the first spiritual church in Nigeria. ${ }^{34}$

Braide died in the year that the Aladura ("people of prayer") movement began to emerge further west. The Aladura movement had its roots in the Anglican CMS (Church Missionary Society) in Nigeria. Joseph Shadare (d. 1962), a lay leader at Ijebu-Ode in the Yoruba country in southwestern Nigeria, formed a prayer group there in 1918 along with schoolteacher Sophia Odunlami, who had a vision in which she was commanded to preach healing and reject medicines. Their group was known as the Precious Stone (Diamond) Society and was created to provide spiritual support and healing for victims of the influenza epidemic. In 1922 the society left the Anglican Church, rejecting both infant baptism and the use of medicine. It began a branch in Lagos and affiliated with a church in Philadelphia called Faith Tabernacle, whose literature had reached Nigeria and emphasized divine healing and baptism by immersion. Contact with the church in the United States was severed in 1925 as a result of doctrinal differences over the Pentecostal gifts of the Spirit (particularly speaking in tongues) favored by the Africans, the apparent failure of the Americans to support the church in Nigeria, and the American leader's alleged immorality. ${ }^{35}$ After a remarkable revival in 1930, under Joseph Babalola, the group forged links with the British Apostolic Church and later developed into the independent Christ Apostolic Church, one of the largest Pentecostal churches in Nigeria.

Another Anglican member, Moses Orimolade Tunolashe, began preaching in about 1915 after partially recovering from a long illness. Crowds came to him for prayers for healing during the influenza epidemic of 1918. His practices led to his being known as Baba Aladura ("praying father"), a title used by subsequent leaders of the church that he founded. After his prayers for a fifteen-year-old girl, Abiodun Akinsowon, she awoke from a trance and related her visions of heaven, out-of-body experiences, and instructions to use special prayers and holy water

\footnotetext{
${ }^{34}$ Turner, History, 122, 138-44; Sanneh, West African Christianity, 180-84.

${ }^{35}$ Harold W. Turner, History of an African Independent Church (1): The Church of the Lord (Aladura) (Oxford: Clarendon, 1967), 11-12.
} 
for healing. Like the earlier movement, this one began as a prayer group within the Anglican Church but withdrew from it after heavy criticism. The members of the movement claimed a special relationship with angels, whom they represented on earth. "Captain" Abiodun and Orimolade took the revival to other parts of Yorubaland on extended missionary journeys, where they openly challenged witchcraft. This practice brought them into considerable conflict with both traditional and colonial authorities. In 1925 they founded the first Aladura church and gave it the name the Eternal Sacred Order of Cherubim and Seraphim Society. Several schisms eventually emerged within the Cherubim and Seraphim movement.

The Aladura movement was a Pentecostal revival movement of massive proportions. It was later influenced by western Pentecostalism but usually only by the invitation of African church leaders. This movement fundamentally changed the face of West African Christianity. As they did to the African churches before them, so the Aladura churches themselves were overtaken and affected by a new wave of Pentecostalism that swept over Africa in general and West Africa in particular in the second half of the twentieth century-- but that is another era and another story. ${ }^{36}$ Like the Zionists and Apostolics in southern Africa (who had more Pentecostal influence), these churches presented a more daunting challenge to older European churches than the earlier "African" churches had done. Their growth posed fundamental questions about the nature of Christianity and its leadership in Africa.

\section{South African Pentecostalism 1908-1918}

South Africa was one of the earliest and most favored places for Pentecostal missionaries. Thomas Hezmalhalch (1847-1934), along with John G. (1870-1935) and Jenny Lake, Jacob and Lily Lehman, and others began the Apostolic Faith Mission in South Africa in 1908. Hezmalhalch had been a Holiness pastor who had received Spirit baptism at Azusa Street. He led a new Pentecostal outreach in Zion City, Illinois, where he became acquainted with Lake. Lake was a former elder there and in 1906 had received Spirit baptism through the ministry of Charles Parham in Zion City. The team was identified with the Pentecostal work in Indianapolis. Hezmalhalch was regarded as the leader of this group and became the first president of the Apostolic Faith Mission, although Lake was more charismatic. ${ }^{37}$ The Lehmans were returning missionaries who had spent six years in South

\footnotetext{
${ }^{36}$ Allan Anderson, African Reformation: African Initiated Christianity in the 20th Century (Trenton: Africa World Press, 2001), 172-76.

${ }^{37}$ Apostolic Faith 5 (Jan 1907), 3, 4; Robeck, Azusa Street, 274-80; Kemp Pendleton Burpeau, God's Showman: A Historical Study of John G. Lake and South African/American Pentecostalism (Oslo: Refleks Publishing, 2004), 44-45.
} 
Africa. They were able to speak Zulu and had received Spirit baptism at Cook's meetings in Indianapolis. The Zionist connections of the American missionaries proved extremely fruitful. Pieter L. le Roux, a former Dutch Reformed missionary working in Wakkerstroom, near the Natal border, had joined South African Zionist leader John Alexander Dowie's movement in 1902 or 1903 and had become an elder. They had been baptized in 1904 by Daniel Bryant, Dowie's appointed Overseer for South Africa, and by 1905 the group numbered 5,000. ${ }^{38}$ Le Roux, an Afrikaner, was to become the first South African president of the Apostolic Faith Mission (AFM) of South Africa, a position he held for more than thirty years.

There were other fortuitous circumstances for the Pentecostals as well. Bryant, on his return to the United States in 1906, became disaffected with Dowie's successor, Wilbur Voliva, and left the movement. He also encouraged his followers to seek a deeper baptism in the Spirit. It seems that his disaffection spread to his South African followers, who welcomed the Zionists-turned-Pentecostals with open arms. Bryant led a large faction in Zion City, and a letter from Lake to Bryant referring to some of his former converts in Johannesburg appeared in Pentecostal publications. Meanwhile, Bryant was a featured preacher in a Pentecostal convention in Indianapolis in $1910 .{ }^{39}$ Le Roux's Zion converts in the Wakkerstroom area became the source from which a whole series of African Zionist denominations eventually emerged throughout southern Africa. Two of the Zulu leaders associated with le Roux were Daniel Nkonyane and Fred Luthuli, both of whom already had hundreds of followers of their own by 1905 and went on to found significant African independent Zionist churches after breaking with the AFM in $1910 .^{40}$ The reports refer to "native evangelists" but, as usual, do not mention names. We do know that one of those working in this region with le Roux was Daniel Nkonyane, who later led one of the first African secessions. It appears that the growth of South African Pentecostalism among the African population was initially a result of Zionist leaders' joining the movement and reports of healings. American missionaries used these Zionist contacts to promote their work. ${ }^{41}$

The first all-white executive council of the AFM, appointed in 1909, consisted of five Americans and two Afrikaners. ${ }^{42}$ During a meeting that year, white representatives of the Zion church and the AFM executives agreed that le Roux would be in charge of the Zion mission work (African churches) in the Transvaal and that

\footnotetext{
${ }^{38}$ Leaves of Healing 15:25 (8 Oct 1904), 853-54; 18:11 (30 Dec 1905), 314-20.

${ }^{39}$ Bridegroom 's Messenger 29 (1 Jan 1909), 4; Word \& Work 32:7 (July 1910), 213; Triumphs

of Faith 30:9 (Sept 1910), 195; Burton, When God Makes, 31.

${ }^{40}$ Leaves of Healing 18:11 (30 Dec 1905), 317.

${ }^{41}$ Pentecost 1:4 (Dec 1908), 2.

${ }^{42}$ Bridegroom's Messenger 45 (1 Sept 1909), 2; Upper Room 2:3 (Nov 1910), 6.
} 
these two organizations would "mutually acknowledge each other's [preaching] certificates." Pentecostalism did not take the place of Dowie's Zionism in South Africa, but the new message of the power of the Spirit was simply added to it. The executive council resolved in 1910 that "whereas the natives deem the name of Zion so essential that this portion of our Mission be known henceforth as the Zion Branch of the Apostolic Faith Mission." ${ }^{\prime 43}$ Letters appearing in the Pentecostal periodicals reported on extensive work being carried on in the Free State and Lesotho, largely through the efforts of Edward Lion and Edgar Mahon. Large "native conferences" were held every year by Lake and his team in Bloemfontein. The seeds of division had already formed. Africans leaders with their proven talents were simply left out of all administrative authority. Lehman was forced to have the Africans worship in the same building in Commissioner Street, Johannesburg (at different times than the whites), but this was clearly a temporary measure until he could procure a separate building for them. ${ }^{44}$ South African Pentecostalism was very quickly segregated. Although the very first meetings in the Zion church in Johannesburg were integrated, within a few months segregation became the common practice. This led to a whole series of secessions from 1910 onward, when Daniel Nkonyane started the first "Zulu Zion" church. ${ }^{45}$

There is much less information available about the many early African Pentecostal leaders in South Africa than there is about Lake and his expatriate missionaries. These African leaders made the movement vigorous and dynamic, missionaries and pioneers in their own right, with influence far beyond their own churches' spheres. They played a remarkable role in the development of Christianity in South Africa. Some of the most significant leaders at this early stage were Elias Letwaba (1870-1959), a prominent leader who worked with Lake in the Transvaal and never left the AFM; Edward Lion, who was overseer of AFM work in Lesotho, led a remarkable healing ministry, and founded the Zion Apostolic Faith Mission; and above all, Engenas Lekganyane (1880-1948), founder of the largest Christian denomination in South Africa, the Zion Christian Church. All three were AFM preachers at one stage in their lives ${ }^{46} \mathrm{Clearly}$, the work of A. Lehman and others in the gold mines that employed contract workers from several southern African countries was an important means of spreading Pentecostal ideas in ways that the western missionaries could not have imagined,

\footnotetext{
${ }^{43}$ Quoted in Christiaan R. de Wet, "The Apostolic Faith Mission in Africa: 1908-1980. A case study in church growth in a segregated society," $\mathrm{PhD}$ thesis, University of Cape Town, 1989, 34, 64.

${ }^{44}$ Weekly Evangel 214 (10 Nov 1917), 13.

${ }^{45}$ B.G.M. Sundkler, Zulu Zion and Some Swazi Zionists (London: Oxford University Press, 1976), 55-56, n54.

${ }^{46}$ Anderson, Spreading Fires, 173-80.
} 
and it certainly played a significant role in the increasing pentecostalization of newly emerging independent churches.

In 1910 Lake reported that there were 250 "native preachers" and a hundred white preachers in the AFM. Lehman was one of the few who attempted to give credit to African workers. ${ }^{47}$ In 1916 the Secretary of the AFM, Frank Dugmore, published a significant letter, of which I reproduce a portion:

Our policy is, and has been from the beginning, one of trusting the native. It would seem that right here has been the failure in all the Mission work that has been done in South Africa. The natives have been trusted, and have failed; the trust has been withdrawn, and color has been blamed, and confidence has been destroyed.

God has put in no color bar in His Word, and the example of our Lord was to choose ignorant fisher men to be His representatives, and to endue with His heavenly power.

The natives are able preachers, and, though they sometimes err in doctrine, they are mighty in faith. The native peoples of South Africa are awakening from their dark past. Self-consciousness and national consciousness is dawning among them. This is naturally evident among their leading thinkers, who are usually religious men also.

Before the event of the Apostolic Faith Mission in South Africa, Ethiopianism (a word used to describe a spirit of Independence and refusal to recognize European control among the natives of South Africa) was a strong force. Within the AFM they have found that they are trusted, and given scope to work for the Lord, so that today Ethiopianism is nothing like the same force that it was, and this forward movement among the natives which is out of touch with the Government, has the touch and sympathy of the Europeans of the Apostolic Faith Mission.

We have big responsibilities resting upon us, and a situation that always needs the most delicate handling. Could we take hold of this movement among the natives for God, in the manner and measure that I think God would have us do, it could sweep right through South Africa, and not only South Africa, but Central Africa, and the Soudan. ${ }^{48}$

\footnotetext{
${ }^{47}$ Bridegroom's Messenger 56 (15 Feb 1910), 1; 58 (15 Mar 1910), 3; 74 (15 Nov 1910), 2; Pent 1:7 (June 1909), 1-2; 1:10 (Sept 1909), 3.

${ }^{48}$ Weekly Evangel 126 (12 Feb 1916), 13.
} 
Amazing as this prophetic letter was, Dugmore was still an American whose enlightened views were certainly not shared by all white South African Pentecostals. Clearly, the AFM saw itself as a catalyst for the channeling of African preachers into their work rather than into independence. As the following years were to show, despite Dugmore's admirable intentions, they did not handle this very well (to put it mildly), and Africans began to resist the domination of white overseers over what was largely their work. Some missionaries believed that Dugmore's policy went too far. Congo missionary William Burton wrote that Lake had been adopting Ethiopian churches that were often "turned into breeding grounds for anti-European political propaganda" and "start to teach freedom from the European rule." "49 God forbid that that should ever happen! And of course, many early African leaders did not enjoy the same harmonious relationship with the white AFM leaders that Letwaba did. The trust broke down, and in the majority of cases the Africans began to work independently of the whites.

The existence of strong independent churches today has much to do with early Pentecostal missions. There are indications that Pentecostal missionaries tapped into a new phenomenon that was particularly strong in South Africa. Near Middelburg, Lehman held services to welcome a group of secessionists into the Pentecostal fold, and Lake visited an "Ethiopian" church conference that was seeking affiliation with the AFM. Lake wrote of "native missionary" Paul Mabiletsa, who told Lake about a paralyzed woman healed through prayer in the Germiston district. In 1920, Mabiletsa founded the Apostolic Church in Zion, which became one of the larger Zionist churches and whose leadership remained in the Mabiletsa family. Lake himself reported that twenty-four "native Catholic churches" and "five large Ethiopian churches" had decided to affiliate with the AFM in 1910 and that the "African Catholic Church," with 78 preachers, joined in January 1911. Again in 1911 the Ethiopian Church affiliated with Pastor Modred Powell, to become the Apostolic Faith Church of South Africa. Many of the early Pentecostal converts in South Africa were already members of Christian churches, especially African independent ones. ${ }^{50}$ But the flow went both ways: by 1915 there were several secessions from the Pentecostals, especially from the AFM. American Assemblies of God missionary Turney also complained of African women who had "risen up refusing to acknowledge any authority in the church" and who were "trying to establish a church of their own, with a native as leader." 51

\footnotetext{
${ }^{49}$ Burton, When God Makes, 84.

${ }^{50}$ Bridegroom's Messenger 52 (15 Dec 1909), 4: Upper Room 1:10 (May 1910), 6; 2:2 (Sept-Oct 1910), 3; 2:4 (Jan 1911), 6, 8; 2:5 (May 1911), 6; Confidence 4:12 (Dec 1911), 284; Anderson, African Reformation, 97.

${ }^{51}$ Weekly Evangel 124 (22 Jan 1916). 13.
} 
It is important to note the role of Pentecostalism and expatriate Pentecostal missionaries in the early years of African, Indian, and Chinese independence and the links with some of its most significant leaders. The independent Zionist and Apostolic churches in South Africa together form the largest group of Christians in the country today. Although the independent churches may no longer be described as Pentecostal without further qualification, the most characteristic features of their theology and praxis is overwhelmingly Pentecostal and, in the case of South Africa, also influenced by the Zionist movement of John Alexander Dowie. Healing, prophecy, speaking in tongues, and baptism by immersion (usually threefold), and even the rejection of medicine and eating pork, are some of the features that remain among these African churches. Although these churches have gradually increased the distance between themselves and "classical" Pentecostalism in liturgy and practice, their growth and proliferation are further evidence of the rapidly "spreading fires" of the Spirit in Africa and deserve to be accounted for in any historical research on Pentecostalism. In southern Africa, they were sometimes aided and abetted by foreign Pentecostal missionaries, who worked with them for a while but whose ideas African leaders borrowed freely yet selectively. This was a specifically African Christian response, despite the outward trappings of rituals and customs that were innovations rather than continuations of African symbols. In this regard, these new African churches represented a radical reformation of African Christianity. ${ }^{52}$ As Lamin Sanneh pointed out, charismatic Christianity "is largely responsible for the dramatic shift in the religion's center of gravity." ${ }^{33}$ Whatever their motivation might have been, Pentecostal missions in Africa, Asia, and Latin America unwittingly served as catalysts for this larger movement of the Spirit that was to dominate global Christianity for the remainder of the twentieth century.

\footnotetext{
52 Anderson, African Reformation, 51-64.

${ }^{53}$ Lamin Sanneh, Disciples of All Nations: Pillars of World Christianity (New York: Oxford, 2008), 275.
} 


\section{The Role of Feminism(s) in Theology and the Church: Reflections from a Feminist Pastoral Theologian ${ }^{1}$}

by Pamela Cooper-White

Pamela Cooper-White delivered this lecture at Princeton Theological Seminary on February 28, 2008, as the Annual WICAM Lecture. Rev. CooperWhite currently serves as the Ben G. and Nancye Clapp Gautier Professor of Pastoral Theology, Care, and Counseling, at the Columbia Theological Seminary, Decatur, GA, and teaches in the Atlanta Theological Consortium's ThD program in pastoral counseling and theology. She is author of numerous publications, including Many Voices: Pastoral Psychotherapy in Relational and Theological Perspective; Shared Wisdom: Use of the Self in Pastoral Care and Counseling; and The Cry of Tamar: Violence against Women and the Church's Response.

\section{$W_{\text {h }}$ hat is feminism? There are actually many feminisms, ranging from liberal American to radical (Marxist) to postmodern to global and developing world- more on that in a moment. But if I were to try to come up with an umbrella definition, I would say that feminism means taking seriously the call for social, economic, and political parity and equal rights and responsibilities, of women with men, and looking unflinchingly at the painful realities, and the negative impact on both men and women, of patriarchalism (literally, rule of the fathers), both historically (especially in Christian theology as it pertains to the history of the church) and in contemporary societies.}

Feminist Christian theologies, then, point out the gaps and distortions both in the historical record and in the biblical witness itself - gaps and distortions about women - women's experiences, spirituality, and contributions, and the relative absence or discounting of women's voices in the theological tradition. In addition, feminist theologies take up issues that have historically been of concern

\footnotetext{
${ }^{1}$ A later version of this lecture appears in Pastoral Theology 18, 2 (2008): 18-46.
}

DOI: $10.3754 / 1937-8386.2009 .30 .5$ 
to women but often neglected in "traditional" theology, including such topics as the body and the role of subjective experience and relationships, and such sociopolitical issues as violence against women and children. Because oppression is both a catalyst and a theme for feminist theologies, the integrative linking of women's oppression with racial, class, sexual orientation, and other forms of oppression is also always of central concern.

What does this boil down to? As a feminist pastoral theologian, I will argue that all theology-but especially pastoral theology, which is concerned with care for suffering - must begin with human beings and, in particular, the pain and brokenness of the human condition (and indeed, all creation). As David Tracy ${ }^{2}$ argues, drawing from Paul Tillich, ${ }^{3}$ there must be a mutual dialogue or "critical correlation" back and forth between theology and the human situation. Even more recently, Mark Lewis Taylor extends this view of critical correlation toward a cultural-political theology that is critically self-reflexive in relation to the larger issues of culture and power and refuses to bifurcate theological tradition from experience. ${ }^{4}$ Pastoral theology begins with what Ada-María Isasi-Díaz calls "lo cotidiano" - the realities of daily life. ${ }^{5}$ In particular, it takes human suffering as its starting place-in Jürgen Moltmann's words, "the open wound of life in this world." The classic pastoral functions, as articulated in the mid-twentieth century (and amended in recent decades), immerse the pastoral theologian directly in this open wound, through a commitment to ministries of healing, sustaining, guiding, reconciling, ${ }^{7}$ and —citing the more recent work of womanist pastoral theologian Carroll Watkins Ali-also nurturing, liberating, and empowering. ${ }^{8}$

Moreover, as a feminist theologian, I am always going to try to resist the inertia that works against common awareness of the oppression of women in our culture. I will have to try especially hard to be attentive to including and empowering women's voices in my own work and in my contexts of teaching and ministry; it means lifting up women's issues in my writing and ministry;

\footnotetext{
${ }^{2}$ David Tracy, Blessed Rage for Order (New York: Seabury, 1975).

${ }^{3}$ Paul Tillich, Systematic Theology (Chicago: University of Chicago Press, 1967).

${ }^{4}$ Mark Lewis Taylor, Remembering Esperanza: A Cultural-Political Theology for North American Praxis (Minneapolis: Fortress reissue, 2005; orig. publ. Mark Kline Taylor, Orbis Press, 1989).

${ }^{5}$ Ada-María Isasi-Díaz, Mujerista Theology: A Theology for the Twenty-first Century (Louisville: Westminster-John Knox Press, 1996).

${ }^{6}$ Jürgen Moltmann, The Trinity and the Kingdom (Minneapolis: Fortress Press, 1993), 49.

${ }^{7}$ W. A. Clebsch and C. R. Jaekle, Pastoral Care in Historical Perspective (Englewood Cliffs: Prentice Hall, 1983).

${ }^{8}$ Carroll Watkins Ali, Survival and Liberation: Pastoral Theology in African American Context (St. Louis: Chalice, 1999).
} 
and it means working on my own gender-, race-, class- and other culturally ingrained biases and seeking collaborative partnerships across such socially constructed divides.

More autobiographically, I can say that in my own formation over the years, I have moved through more than one form of feminism and feminist theologyas is probably very true of many women here in the audience tonight. Twenty years ago (hard to imagine it's been that long!), when I was the director of the Center for Women and Religion at the Graduate Theological Union in Berkeley, California, ${ }^{9}$ there were perhaps three identifiable, though overlapping, paradigms of feminism operative within the institutional church and within theological education in the United States. ${ }^{10}$

\section{RADICAL FEMINISM}

Using the language of the women who adhere to each of these perspectives, the first would be "radical" or "progressive" feminism. Grounded in Marxistfeminist ideals (whether conscious or absorbed by osmosis through 1960s radical feminism) of an alternative, nonhierarchical collective, and promoting consciousness raising as a tool for awakening feminist movement for justice constituted the ideals of "second-wave" radical feminism from the 1960s, this form of feminism involves critical analysis, public advocacy, and community organizing around concrete manifestations of oppression of women. The goal of this form of feminism is essentially revolutionary (even if the form it usually takes in an academic or church context is mainly via persuasion and education) - the overthrow of existing structures, patterns, and institutions that perpetuated oppression, and the hope of a new, egalitarian social order.

Within theological education, this has been seen, for example, in courses in which students develop a syllabus and take turns facilitating sessions. It can also be seen in the growing interest among many to be involved in political activism beyond seminary walls, with research, programs, and publications that promote radical — that is, to-the-root causes - analysis of economic

\footnotetext{
${ }^{9}$ For a discussion of the history of this Center, and reflections on these forms of feminism in the GTU context, see Cooper-White, "The Early 1990s: Whose CWR? Whose Feminism?" in Feminist Theologies: Legacy and Prospect, ed. Rosemary Radford Ruether (Minneapolis: Fortress Press, 2007), 16-28.

${ }^{10}$ For detailed examples of texts representing each of the schools of feminism discussed in this lecture, see Cooper-White, "Feminism(s), Gender, and Power: Reflection from a Feminist Pastoral Theologian," Pastoral Theology 18, 2 (2008): 19-22.
} 
injustice, violence against women, and an analysis linking the oppressions of racism, sexism, classism, economic and sexual violence against women, and heterosexism. Theologically, this radical method is guided by a hermeneutics of suspicion and a rejection of patriarchal images of God that reinforce women's subordination.

\section{LIBERAL FEMINISM}

The second form of feminism evident in the institutional church and theological education is what most Americans would simply call "feminism," social analysts might call "liberal feminism," and its detractors, as I once heard pejoratively spoken by some of the radical feminists, call "NOW-style bourgeois feminism." The goal of liberal feminism is not so much the overthrow of existing social structures as the equal access of women to the privilege, decision making, power, and authority enjoyed by men within those structures. If Marxism is the underlying politics of radical feminism, then Enlightenment values of liberty, brother-and-sisterhood, and equality are the rallying cry of liberal feminism. In the context of the church and theological education, this strand may be seen in the movement for the ordination of women in those denominations that do not yet admit women to all levels of leadership; efforts to break through the "stained glass ceiling" of assistant and associate pastorates in those denominations that do ordain women; advocacy within seminaries for more women faculty; the promotion of existing women faculty to tenured rank (a very real battle for some women); and encouragement of women Ph.D. students and faculty to publish feminist scholarship. Theologically, one scholarly approach within the liberal feminist movement has been to appropriate the thought and/or methodology of major nineteenth- and twentieth-century theologians such as Barth, Niebuhr, and Schleiermacher, or to go back to ancient sources, such as Augustine and Aquinas or even the Bible itself-recovering women's voices and leadership in antiquity - to show that women deserve an equal place of power in church and society.

My first pastoral theological book, The Cry of Tamar: Violence against Women and the Church's Response, ${ }^{11}$ published in 1995, stands within both of these "second-wave" feminist movements, drawing from radical feminism in my critique of patriarchal structures that perpetuate the subjugation of women in our North American society and drawing from liberal feminism in my continu-

"Cooper-White, The Cry of Tamar: Violence against Women and the Church's Response (Minneapolis: Fortress Press, 1995). 
ing, dogged embrace of the church as a place of hope and redemption-in spite of its flawed, human history.

\section{EsSENTIALIST FEMINISM}

Emerging especially in the 1980 s, there has been a third form of feminism especially in North America that might be termed "essentialist feminism." In the realm of women and religion, this form of feminism grew out of the women's spirituality movement and existed mainly in conversation and in contrast to liberal feminism. If liberal feminists are seeking equality with men, essentialist feminists celebrate a model of essential, even innate differences between women and men. Like liberal feminists, they advocate for an equal valuation of women but criticize liberal feminists for "trying to be like men." In the social sciences, Carol Gilligan's work In a Different Voice, with which many of you may be familiar, would fall into this category of research. ${ }^{12}$ This branch of feminism embraces a matriarchal or sororal ideal of women as nurturing, intuitive, creative, collaborative, and, like their radical feminist sisters, nonhierarchical. Their vision, however, is more utopian than revolutionary per se. Often somewhat separatist in their spiritual practices, many of these women have sought to recover or reconstruct ancient and premodern forms of goddess worship, and "women's ways of knowing," which could be taught and practiced by both women and men alike. ${ }^{13}$ This strand of feminism casts a wide net, including some Jungians, wiccans, ecofeminists, and the feminist spirituality movement and is best characterized by movements nurturing women's spirituality. The pastoral caregiver in me resonates with some of the healing that women have found in this movement, although I am too much of a psychoanalytic skeptic to fully embrace the overidealization of women I sometimes find there.

\section{OTHER Forms OF FEMINISM}

A multiplicity of forms of feminism began emerging multiculturally in the 1980s as: womanist, black feminist, mujerista, Asian, and developing; "global," or "two-thirds world" feminist voices; as well as lesbian and bisexual women's voices, began to be heard and published in both religious

${ }^{12}$ Carol Gilligan, In a Different Voice: Psychological Theory and Women's Development (Cambridge: Harvard University Press, 1982).

${ }^{13}$ Mary Belenky et al., Women's Ways of Knowing: The Development of Self, Voice, and Mind (New York: Basic Books, 1996). 
institutions and the academy. Many of us began to work for greater diversity of women of color, non-Christian women, and also of lesbian-bisexual women in theological publications and programs during this time. We have made some important inroads, and opened some dialogue-although, as most women of color, and most queer women will tell us, we still have a long way to go in decentering heterosexual and white privilege from our feminist discourse(s).

Most recently, postmodern and postcolonial feminisms have opened up in theology and in theological education. Both of these theoretical approaches share a concern with deconstructing hegemonic or "dominant discourses" that perpetuate political and social inequalities. ${ }^{14}$ Both have offered conceptual frameworks and methods for analysis and dialogue, which are making important contributions to the very crucial question of how women - especially black, Latina, Asian, African, third world, "subaltern," and queer women - "can speak" (to quote such theorists as Judith Butler, ${ }^{15}$ Luce Irigaray, ${ }^{16}$ and Gayatri Spivak ${ }^{17}$ : Can women speak?). Can we speak to and with each other? What both postmodernism and postcolonialism represent through differing lenses-in a vastly oversimplistic generalization - is a critique of universal "truths" or truth claims that have historically masked diversity of cultures, perspectives, and voices, particularly of those marginalized outside the so-called "mainstream" of white, western dominant discourse. This is still a contested area within mainstream Christian theology, but by now there are growing numbers of us who are engaging in serious dialogue with contemporary European-especially French-expressions of feminist thought ${ }^{18}$ (e.g., Luce Irigaray, ${ }^{19}$ Julia Kristeva, ${ }^{20}$ and Hélène

\footnotetext{
${ }^{14}$ Term from Michel Foucault, e.g., Power/Knowledge: Selected Interviews and Other Writings, 1972-1977 (New York: Pantheon, 1980).

15 Judith Butler, Gender Trouble: Feminism and the Subversion of Identity (New York: Routledge, 1990).

${ }^{16}$ Luce Irigaray, This Sex Which Is Not One, trans. C. Porter (Ithaca: Cornell University Press, 1985), 83, 89, 111.

${ }^{17}$ Gayatri Chakavorty Spivak, "Can the Subaltern Speak?"' in Marxism and the Interpretation of Culture, C. Nelson and L. Grossberg, eds. (Chicago: University of Illinois Press, 1988), 271-313 (orig. publ. in Wedge 7/8 [1985], 120-30).

${ }^{18}$ For a wonderful introduction to the implications of French postmodern feminism for feminist theology, also see C. W. Kim et al., eds., Transfigurations: Theology and the French Feminists (Minneapolis: Fortress Press, 1993).

${ }^{19}$ For example, Luce Irigaray, Speculum of the Other Woman, trans. G. C. Gill (Ithaca: Cornell University Press, 1985); and This Sex Which Is Not One, trans. C. Porter (Ithaca: Cornell University Press, 1985).

${ }^{20}$ For example, Julia Kristeva, In the Beginning Was Love: Psychoanalysis and Faith, trans. A. Goldhammer (New York: Columbia University Press, 1987); and The Kristeva Reader, T. Moi, ed. (New York: Columbia University Press, 1986).
} 
Cixous $^{21}$; postmodern thinkers such as Jacques Derrida ${ }^{22}$ and Michel Foucault ${ }^{23}$; postcolonial theorists across the globe such as Homi Bhabha ${ }^{24}$ and Gayatri Spivak ${ }^{25}$; and here in the United States gender theorists within cultural studies, queer theory, and contemporary psychoanalysis, such as Jane Flax ${ }^{26}$ and Judith Butler $^{27}$ ).

\section{FEMINISM AND THEOLOGY}

Through my own forays, increasingly in the past ten years especially, into psychoanalytic theory at the intersection of feminism, I have been trying to forge a way for theology to become a third conversation partner in that dialogue. Out of this struggle came my 2004 book, Shared Wisdom: Use of the Self in Pastoral Care and Counseling, ${ }^{28}$ and the book I completed two years ago, titled Many Voices: Pastoral Psychotherapy in Relational and Theological Perspective. ${ }^{29}$ In the books the theme of multiplicity - of human beings, of God, and of modes of attention in pastoral practice-is a central organizing trope.

Drawing both from postmodern understandings of the diversity of truths, and from the postcolonial notion of hybridity, ${ }^{30}$ in which dialogue partners join together in new creative ways without losing their individual distinctiveness, I am interested in a pastoral theological anthropology that explores the multiplicity of persons, not only in terms of pluralism and diversity of human beings in

\footnotetext{
${ }^{21}$ Hélène Cixous, The Hélène Cixous Reader, S. Sellers, ed. (London: Routledge, 1994); Cixous and Catherine Clément, The Newly Born Woman, trans. B. Wing (Minneapolis: University of Minnesota Press, 1986).

${ }^{22}$ For example, Jacques Derrida, Of Grammatology, trans. G. C. Spivak (Baltimore: Johns Hopkins University Press, 1976); Writing and Difference, trans. A. Bass (Chicago: University of Chicago Press, 1978).

${ }^{23}$ Michel Foucault, Language, Counter-Memory and Practice: Selected Essays and Interviews by Michel Foucault, D. Bouchard, ed. (Ithaca: Cornell University Press, 1977); and Power/ Knowledge.

${ }^{24}$ Homi Bhabha, The Location of Culture (New York: Routledge, 1994).

${ }^{25}$ Spivak, A Critique of Postcolonial Reason: Toward a History of the Vanishing Present (Cambridge: Harvard University Press, 1999).

${ }^{26}$ For example, Jane Flax, Disputed Subjects: Essays on Psychoanalysis, Politics and Philosophy (New York: Routledge, 1993).

27 Judith Butler, Gender Trouble: Feminism and the Subversion of Identity (New York:

Routledge, 1990)

${ }^{28}$ Pamela Cooper-White, Shared Wisdom: Use of the Self in Pastoral Care and Counseling (Minneapolis: Fortress Press, 2004).

${ }^{29}$ Cooper-White, Many Voices: Pastoral Psychotherapy in Relational and Theological Perspective (Minneapolis: Fortress Press, 2007).

${ }^{30}$ Homi Bhabha, The Location of Culture.
} 
our relations with one another, but multiplicity as internally constitutive of each individual $\mathrm{mind} / \mathrm{self} / \mathrm{subject}$, at both conscious and unconscious levels. ${ }^{31}$

An appreciation for this multiplicity informs a corresponding pastoral psychotherapeutic praxis, as a method of working with all the varied, contradictory and creative parts of each patient in his or her many self-states, identifications, and subjective moments. Imagine mind and self in terms of a three-dimensional multiplicity (or more) —neither vertical "depth," nor purely horizontal "plane," but an infinitely dimensional, quantum substance, with internal indeterminacy and some fluid external parameters. Imagine a subjectivity, a multiple self, identifiable as both an "I" and a "Thou" simultaneously, subject and object, "self" and "other," and with a mobile consciousness that scans and networks various parts of the "self," in an illusory but functional sense of self-cohesion, self-regulation, and self-continuity. Such a model of pastoral psychotherapy seeks to help individuals come to know, accept, and even appreciate all the distinctive parts - the many voices-that live within them. ${ }^{32}$

There is a political and ethical dimension to this reconceptualization as well. Being open to a variety of "others" within the web that constitutes oneself, it seems to me, should potentiate a greater openness to "others" beyond oneself. The idea of a multiple self as emancipatory also relates to the dimension of time and to the flow of selves in relational process. Drawing from Luce Irigaray, feminist postmodern theorist and psychoanalyst Jane Flax describes multiplicity and fluidity of subjects as emancipatory:

I believe a unitary self is unnecessary, impossible, and a dangerous illusion. Only multiple subjects can invent ways to struggle against domination that will not merely recreate it. In the process of therapy, in relations with others, and in political life we encounter many difficulties when subjectivity becomes subject to one normative standard, solidifies into rigid structures, or lacks the capacity to flow readily between different aspects of itself ... No singular form can be sufficient as a regulative ideal or as a prescription for human maturity or the essential human capacity ... [I]t is possible to imagine subjectivities whose desires for multiplicity can impel them toward emancipa-

\footnotetext{
${ }^{31}$ Cooper-White, "Higher Powers and Infernal Regions: Models of Mind in Freud's 'Interpretation of Dreams' and Contemporary Psychoanalysis," Pastoral Psychology 50/5 (2002), 319-43; see also Shared Wisdom.

${ }^{32}$ For a detailed discussion of multiplicity in pastoral psychotherapy and theology, see CooperWhite, Many Voices.
} 
tory action. These subjectivities would be fluid rather than solid, contextual rather than universal, and process oriented rather than topographical. Emancipatory theories and practices requires mechanics of fluids ${ }^{33}$ in which subjectivity is conceived as processes rather than as a fixed atemporal entity locatable in a homogeneous, abstract time and space. ${ }^{34}$

Postmodern writers thus highlight the ethical implications of a non-unitary conception of self and mind, especially as they influence the social construction of self and others, and the resulting social construction of categories such as gender, race and class, and the distribution of power. ${ }^{35} \mathrm{~A}$ corresponding psychotherapeutic approach would have as its goal an increasingly harmonious awareness and constructive dialogue among all the disparate parts, conscious and unconscious, of the person who comes for help, rather than an integration of conscious and unconscious into one homogenized whole.

As unsettling as we may find this more multiple, fluid, and spatially conceived model of mind, relational psychoanalytic theory, philosophy, physics, and neurobiology are all converging to suggest that the postmodern view may be a more generous and apt description of the true complexity and multiplicity of mental life. In fact, given the complex, demanding, and pluralistic nature of our postmodern world, mental health may depend as much on the capacity for "identity complexity" 36 as it does on a capacity for psychological "integration." 37

Such an embracing of multiplicity has a particularly feminist ring, I think, because feminism/feminism(s)/Womanism/mujerisma, as I have tried to show here, is/are also multiple. Feminism is such a complex area of thought, it is not the case that we have proceeded in some linear fashion from Marxist and liberal feminism to postmodernism and postcolonialism, to something more or better. Such a "progress model" would be both modernist and very unfeminist! We bring it all along with us, in a big, roiling, complex mess of ideas,

\footnotetext{
${ }^{33}$ This term is from Luce Irigaray, "The Mechanics of Fluids," in This Sex Which Is Not One, 106-18.

${ }^{34}$ Jane Flax, "Multiples," in Disputed Subjects, 93.

${ }^{35}$ For further elaboration of the relationship between postmodernism and justice, including an appropriation of D. W. Winnicott's Playing and Reality, see Jane Flax, "The Play of Justice," in Disputed Subjects, 111-28.

${ }^{36}$ Cf., Carolyn Saari, "Identity Complexity as an Indicator of Mental Health," Clinical Social Work Journal 21/1 (1993), 11-23.

${ }^{37}$ Cooper-White, "Interrogating Integration, Dissenting Dis-integration: Multiplicity as a Positive Metaphor in Therapy and Theology," Pastoral Psychologv 56 (2008), 3-16.
} 
critiques, and practices. But I think in the past three decades or so, we have developed sharper and more discriminating tools to evaluate our work. With the influence of postmodern and postcolonial critiques, we are no longer able to embrace the sometimes simplistic and univocal (often white, middle-class) certainties of the 1960s and 1970s. But it would be a mistake to say that feminism in theology is passé!

I now identify myself as a postmodern theologian and am intrigued by the idea that postmodernism itself, while critiquing the hyperrational and universalizing hubris found in eighteenth- and nineteenth-century modernist thought, is nevertheless in some sense an extension of Enlightenment values of justice and equality.

\section{REALITY VERSUS DELUSION}

For me, the crux of where this is still quite evident in feminist work is in the analysis of power and the overarching context of political, economic, and institutional subjugation of women's voices - together with all other subjugated populations. This begins with a consideration of the very nature of subjectivity-our experiences, and our relative perspectives - and how these experiences and perspectives are not neutral, but gendered, as we are socialized into our identities as women and men.

Whether by nature or nurture, we, women and men, are all sitting here in the same room, but we are not sitting in the same reality. Reality is socially constructed.$^{38}$ Because we don't all have the same social experiences, or even the same access to the agora - the marketplace of social dealings-we don't have equal access to the reality-constructing process. Tonight we're focusing on gender, but we might just as well be focusing on race, or class, or sexual orientation, or physical ability, or age. Some groups have the authority to build and name reality for others. And although there is change, as evidenced by the presence of many women here tonight who are in professional roles and preparing for ministry or other forms of leadership, and we have both a woman and a black man

\footnotetext{
${ }^{38}$ This position is summarized in Cooper-White, Shared Wisdom, 35-56; see also Peter Berger and Thomas Luckmann, The Social Construction of Reality: A Treatise in the Sociology of Knowledge (New York: Anchor, 1967); Egon Guba, "The Alternative Paradigm Dialog," in The Paradigm Dialog, Egon G. Guba, ed. (Newbury Park: Sage Publications, 1990), 17-27; Kenneth Gergen, "The Social Constructionist Movement in Modern Psychology, American Psychologist 40/3 (1085), 266-75; Gergen, "Psychological Science in a Post-modern Context," American Psychologist 56/10 (2001), 803-13; John Shotter and Gergen, Texts of Identity (Newbury Park: Sage Publications, 1989).
} 
as the two top candidates for the Democratic presidential nomination this year, it is still mostly the case that reality is built and named in our society by (mostly white) men and only a small percentage of (mostly white) women. Individual women are left with a terrible double bind: if reality is defined by men, or by the individual man with whom a woman happens to be relating at the moment, then a woman must choose between convincing herself that the other's reality is the "real" one, or clinging perilously to her own perceptions and exposing herself to ridicule, ostracism, or worse. Her reality is nonreality. To choose her reality is therefore to choose being delusional.

I will give you a concrete example. Some time ago I was taking a much-needed day off. I went into the city just to roam around, play tourist, and get a haircut. At the hairdresser's, I was sitting looking like something out of The Jetsons, with rods and pieces of aluminum foil sticking out of my head, with a drab, unisex robe draped around my shoulders, and suddenly I took a good look at the fashion poster that was on display in front of the shampoo station. It was a black and white fashion photograph of a woman with her hair blown across her face. Her face was turned unnaturally to one side, as if it had been slapped, and her eyes had a dull, staged, but provocative look, as in pornography.

Her clothes were half pulled off her body, and even with all of that I wasn't particularly clued in that anything was disturbing about the picture because, like everyone else, I am socialized to think that that is what most high-fashion photographs of women look like, right? And then I saw that her shoulder was visibly, obviously bruised. In this day and age of air-brushed perfection, the bruise could be no accident. I looked and blinked and really couldn't fathom what I was seeing-or why.

And the story isn't even over yet. I walked out of the hairdresser's a while later and went to retrieve my car. While the parking attendant went to get my car, I noticed a picture tacked up over his workstation. Except for a small calendar with no pictures on it, this was the only decoration on his wall. It was a homemade Xerox collage of nude female mannequins, lying down at various angles, with arms and legs chopped off, and photographic faces of real women superimposed where the heads would have been. Again, I looked and blinked and really couldn't fathom what I was seeing-or why. Or what I would feel it I let myself ... and then what in the world I was supposed to do about what I felt.

My socially constructed reality said, "It's nothing. Forget it. So what?" My real-that is, socially delusional-reality said, "Today I have seen two photographs of violence against women, used as style and as decoration. I'm 
a woman and this makes me feel very targeted and very vulnerable." Well, what's a "girl" to do? I shook my newly permed hair, got in my car, and drove home. Whatever protest I might have felt was silenced by the utter, banal normality of both situations. To speak up would have been to be a troublemaker, a fury, a crazy woman.

I did at a later time go back and ask the garage owner about the collage. But not until I had told this story in the context of teaching a seminary class, who by believing me provided me with a validation of the reality of my experience. It was this very important context of an alternative consensual reality that gave me the courage to go back and confront what I had seen.

\section{ASPECTS OF VIOLENCE}

I have been asked why I have written and taught so much about violence against women specifically. Why not just talk about violence, period? In one sense, all violence, whether against women, or men, or girls, or boys, is connected, and I will get back to that a bit later. Violence is never acceptable, and the pain and horror of a boy who is molested, or a man who is raped, mugged, or murdered should not be minimized in any way. These are horrors that deserve to be spoken about and condemned.

The main reason why we need to talk about violence against women, then, is because of the gendered nature of all experiences, including violence. There are certain particular aspects to violence against women that deserve our focused attention in order to be competent, gender-sensitive pastoral caregivers and advocates for prevention.

The first aspect is proportionality. Far more girls and women are disproportionately victims of certain types of violence, particularly sexual assault, sexual abuse, and intimate partner violence. One out of four girls are sexually assaulted before the age of eighteen; the statistic is one out of five to six boys. ${ }^{39}$ Seventeen percent of women, or one in six women, are raped in their lifetimes; 3 percent of men, or one in thirty-three men, are raped in their lifetimes.$^{40}$ Ninety percent

\footnotetext{
${ }^{39}$ David Finkelhor, et al. "Sexual Abuse in a National Survey of Adult Men and Women: Prevalence, Characteristics, and Risk Factors," Child Abuse and Neglect 14 (1990), 19-28.

${ }^{40}$ Patricia Tjaden and Nancy Thoennes, Extent, Nature, and Consequences of Intimate Partner Violence: Findings from the National Violence against Women Survey. Washington, DC: National Institute of Justice and Centers for Disease Control and Prevention; available online at http://www.ncjrs.org/txtfiles 1/nij/181867.txt. See also National Institute for Justice, Victims and Perpetrators, available online at http://www.ojp.usdoj.gov/nij/topics/crime/rape-sexualviolence/victims-perpetrators.htm.
} 
of rape victims are female. ${ }^{41}$ The most recent national statistics show that $85-89$ percent of all victims of intimate relationship violence are women, ${ }^{42}$ resulting in 875,000 to over one million reported incidents of domestic violence in the United States each year, ${ }^{43}$ with other estimates as high as three million incidents per year. ${ }^{44}$ Approximately one in five high school girls report physical or sexual abuse by a dating partner. ${ }^{45}$ The most recent large-scale study, sponsored jointly by the National Institute of Justice and the Centers for Disease Control, found that 25 percent of women have been raped or assaulted by an intimate partner, compared with 7.5 percent of men. ${ }^{46}$

More men are murdered. There is a difference here, too, however. Thirty percent of female homicide victims are killed by an intimate partner, compared with only 5 percent of male victims (Bureau of Justice Statistics), and this statistic has remained relatively stable for decades. As many as one in three emergency room visits by women are for injuries from domestic assaults, and the March of Dimes once determined that battering of women during pregnancy causes more birth defects than all the diseases for which children are immunized, combined. In 1993, the American Medical Association and the Surgeon General both named violent men as a major threat to women's health.

Perhaps the most significant issue of proportionality, then, concerns who is committing violent crimes. Eighty-three to ninety-eight percent of perpetrators of all violent crimes are men. ${ }^{47}$ In 2006 , the most recent year's statistics published by the FBI, 90.9 percent of all murders (of both women and men) were committed

\footnotetext{
${ }^{41}$ In 2003, 19,670 out of 198,840 victims, U.S. Dept. of Justice, Bureau of Justice Statistics, National Crime Victims Survey, p. 9, available online at http://www.ojp.usdoj.gov/bjs/pub/pdf/cv03.pdf. ${ }^{42}$ Tjaden and Thoennes, Extent, Nature, and Consequences of Intimate Partner Violence. ${ }^{43}$ C. M. Rennison, Intimate Partner Violence, publication \#NCJ178247, (Washington, DC: U.S. Department of Justice, Bureau of Justice Statistics, 2000). Available online at http://www .ojp.usdoj.gov.bjs. See also National Resource Center on Domestic Violence, General Domestic Violence Statistics Packet: Using Statistics and Evaluating Research, (Harrisburg: NRCDC, 2002), p. 6, available online at http://new.vawnet.org/Assoc_Files_VAWnet/NRC_ Stats.pdf.

${ }^{44}$ K. S. Collins et al., "Addressing Domestic Violence and Its Consequences," in Policy Report of the Commonwealth Fund Commission on Women's Health (New York: The Commonwealth Fund, 1998); summarized online at http://www.commonwealthfund.org/publications/publications_show .htm?doc_id=235787.

${ }^{45}$ J. Silverman et al., "Dating Violence against Adolescent Girls, ..." Journal of the American Medical Association 286/5 (2001), 572-79; cited online at http://www.lessonsfromliterature .org/docs/Teen-Dating-Violence-Fact-Sheet.pdf.

${ }^{46}$ Tjaden and Thoennes, Extent, Nature, and Consequences of Intimate Partner Violence.

${ }^{47}$ U.S. Dept. of Justice, Bureau of Justice Statistics, National Crime Survey: Statistics re: Offenders, 2005, accessed February 27, 2008, http://www.ojp.usdoj.gov/bjs/pub/html/fjsst/2005/tables/ fjs05st404.htm; U.S. Sentencing Commission, Statistics 2001, accessed February 27, 2008, http://www.ussc.gov/ANNRPT/2001/table5.pdf.
} 
by men. ${ }^{48}$ So the issue becomes one of male violence, of which we are all, both women and men, to varying degrees socialized to protect ourselves against, to fear, and to avoid.

There is a second, perhaps even more compelling reason, however, why we must speak in the particular about violence against women. That is to break silence: to accurately name these various forms of violence. Violence against men is commonly understood in our culture as violence, a crime, a violation of a person's rights. Violence against women, however, in all its various forms, is all too often called something else. We call sexual harassment "just a little joke," or "just flirting," or "making a mountain out of a molehill." We call rape "seduction," a case of a woman "being in the wrong place at the wrong time," or being somewhere she should know better, or a case of a woman "asking for it" by drinking too much, wearing the "wrong" outfit, or being seductive. We call battering "poor communication skills," "poor impulse control" on the part of the batterer; we call it masochism in the woman, or if we're really psychologically sophisticated we call it a "problem in the family system," for which she is also responsible, or if we are of a more Freudian bent, we call it "repetition neurosis," in which she is compulsively re-creating the abusive conditions of her childhood and "acting out" by "seeking inappropriate partners."

One particular nexus between the practice of ministry as a caring profession-or the practice of any profession for that matter-and the subject of gender, power, and violence against women is in the arena of sexual harassment. Sexual harassment intersects with the practice of ministry in two ways-both how we conduct ourselves in relation to those who are in our care, and also how we respond to the stories of those who have been victimized and come to us for help and counsel. A thoughtful examination of sexual harassment can offer us an instructive example about the differing realities of women and men.

Because of the prevalence of violence against women, both in the images of women that surround us everywhere we go-more about that in a few minutes-and in real life, no woman knows whether any form of supposedly mild, even joking, sexual harassment will or will not escalate into more serious harassment, unwanted physical touching, stalking, or even rape. Men who

${ }^{48}$ U.S. Federal Bureau of Investigation, "Expanded Homicide Data Table 3 (from Statistics where Gender Was Known)," in Crime in the United States, accessed February 27, 2008, http://www.fbi.gov/ucr/cius2006/offenses/expanded_information/data/shrtable_03.html. 
actually have little more on their minds than relieving sexual tension with a little "dirty joke" are often baffled to be told that this behavior is inappropriate, partly because they do not recognize the more threatening context within which many women experience their behavior. But given the context of so many other forms of violence against women, a woman may always wonder, "Who knows how far this man might go? Who knows if it's harmless or not?" This is precisely the reasoning behind the modern "reasonable woman" judicial standard for assessing the validity of sexual harassment claims in court:

In a landmark case in 1991, Ellison v. Brady, politically conservative federal appellate court judges established the "reasonable woman" standard, with the following historic statement:

We believe that in evaluating the severity and pervasiveness of sexual harassment, we should focus on the perspective of the victim. If we only examined whether a reasonable person would engage in allegedly harassing conduct, we would run the risk of reinforcing the prevailing level of discrimination. Harassers could continue to harass merely because a particular discriminatory practice was common, and victims of harassment would have no remedy. We therefore prefer to analyze harassment from the victim's perspective. ... We realize that there is a broad range of viewpoints among women as a group, but we believe that many women share common concerns which men do not necessarily share. ... [They continue here with a quotation from social science researchers, describing the prevailing societal context as one "where rape and sex-related violence have reached unprecedented levels, and a vast pornography industry creates continuous images of sexual coercion, objectification, and violence.] ${ }^{49}$

Even in situations where we, as women on the receiving end of harassment, are pretty sure that it won't escalate into violence, we experience the eroding of selfconfidence, self-worth, and a feeling of adult well-being. Almost every clergywoman alive has experienced gender harassment by male colleagues. When I first moved to Chicago and was being introduced around my new diocese, I was called a "girl," a "little lady," and believe it or not, a "chickypoo" by other clergy. A very high-ranking bishop some time ago responded to a professional comment of mine-I was thanking him, ironically, for something he said on behalf of women!- - by telling me how he loved the color of my hair, and it was just like his daughter's. I had greeted him as a colleague, and he responded to me as a (sexualized) daughter. Now we can say that this kind of stuff is no big

\footnotetext{
${ }^{49}$ Kathryn Abrams, "Gender Discrimination and the Transformation of Workplace Norms," Vanderbilt Law Review 42 (1989), 1205.
} 
deal in and of itself, but the constant drip-drip-drip of hearing such remarks at almost every gathering of clergy - or analogously in other professional settings-begins to take on more seriousness. It says, "I don't see you as a colleague." And it also feels like it says, "You don't belong here. Go back home where you do belong."

Power is expressed in many other ways besides sexual harassment, including in settings of ministry. In some ways, sexual harassment is just the tip of the iceberg. Researchers ${ }^{50}$ have observed that power is expressed by the person who initiates touching - thereby presuming to enter the other's body and personal space; who stands closer to whom; who takes more personal space-for example, who sits in a more open posture, legs open or arms stretched out, and who sits more contained, taking up less space? Who controls time? Who is more likely to use familiarities of address first? Who makes more jokes at the other's expense, who chooses topics of discussion, who interrupts more? Even such subtle behaviors as more relaxation, greater use of gesture, less tilting of the head, less smiling, and less eye aversion all subliminally communicate power, authority, and control.

These power behaviors also happen to be stereotypical characteristics of masculine behavior. (And they also happen to be common characteristics of behavior of white persons of either gender toward persons of color.) The question of power, for me, is where the entire argument in favor of an "essentialist" view of masculine and feminine differences falls down. Yes, my husband will drive three miles out of his way to avoid asking directions, whereas I'll jump out at the first available service station and strike up a "relationship." In such matters, masculine and feminine differences are almost cute: his self-sufficiency and independence; my resourcefulness and relational tendency. Much ink has been spilled in the last two decades about the characteristic-or so-called "essential"--differences with which men and women relate, communicate, and make moral judgments. The thrust of such research is to validate difference and to show that women should not be assessed by male norms and standards. But it begs the question of how uncritical acceptance of these differences as "natural" may also perpetuate power, dominance, and striking inequality in the name of natural law and what is "normal."

It also begs the question concerning the poisonous, and often unrecognized, effects these differences have on men. Stress-induced heart attacks and ulcers

\footnotetext{
${ }^{50}$ For example, Nancy Henley, Body Politics: Power, Sex, and Nonverbal Communication. New York: Prentice-Hall, 1977.
} 
have long been associated with men more than women. A study by the Washington University Medical School ${ }^{51}$ reports that although twice as many women as men attempt suicide-at least 200,000 a year, which speaks volumes about women's depression-75\% of the 30,000 completed suicides each year are committed by men. Part of this is due to the more violent, immediately lethal methods of suicide chosen by men. But Dr. George Murphy, professor emeritus of psychiatry at Washington University, further attributes men's more deadly rate of suicide to their socialization not to reach out for help or to talk about feelings, to become emotionally isolated, and to dismiss the need for support with an overreliance on logic, stoicism, and self-sufficiency. Surely this has relevance for the more rudimentary sorts of preventive pastoral care, inviting and creating an atmosphere of permission for men to share their inner thoughts, moods, and feelings, and creating better networks of friendship and support to counter some of the internal and external pressures to conform to stoic, life-denying expectations in the name of "being a man."

Myths about Woman, like all myths, are often founded in some biological reality. However, biology is not destiny (with apologies to Freud!). Individual women as persons are much more than just the biological realities of their lives. Women menstruate, make love, miscarry, give birth, nurse babies, have hot flashes, and feel the ebb and flow of hormones like the lunar tide in great cycles over the lifespan. Women also read and write books, drive buses and tractors, perform surgery, conduct orchestras, manage businesses and governments-and celebrate the Eucharist! Images that focus only on women's biological realities confine women's lives to the level of myth, just as a stereotype (in the literal sense of the word) can only produce a single picture.

But falling over entirely onto the "nurture" or socialization side of the naturenurture debate doesn't provide us with a quick fix by any means. I think there is no question that boys and girls are socialized differently from birth, and maybe even before birth. Strong psychoanalytically based theories argue that as long as women are the primary caretakers of small children, Woman will be identified with providing —or, as is inevitable, not always being able to provide—our most basic survival needs. Psychoanalytic thinkers steeped in Kleinian theory, ${ }^{52}$

\footnotetext{
${ }^{51}$ George Murphy, "Why Women Are Less Likely than Men to Commit Suicide," Comprehensive Psychiatry 39 (1998), 165-75.

${ }^{52}$ Referring to the work of Melanie Klein, British psychoanalyst in the first generation after Freud, and founder of the "object relations" school of psychoanalysis focusing on the primacy of infantile attachment to the mother and the development of unconscious mental representations and projections.
} 
including Nancy Chodorow ${ }^{53}$ and Dorothy Dinnerstein, ${ }^{54}$ and feminist theorists like Carolyn Merchant ${ }^{55}$ at the University of California, have shown the unconscious link between mother, breast, and nature; or in another version, woman, bodily functions, and death. These theorists suggest that, at a preverbal and primal stage, we are programmed to meet Mother as an object, an It, whereas we meet Father somewhat later in the process as a subject, an "I." At the most primitive level of our socially constructed but perhaps biologically influenced psyche, power is therefore invoked to keep Woman, nature, the body, and ultimately mortality, contained and under control. ${ }^{56}$ These authors advocate a major overhauling of our social and sexual arrangements, and in particular a more equal sharing of early parenting by both men and women.

If we try to take the theory of socialization and gender differences back to the professional setting, however, it isn't so simple. We find that it doesn't work to attempt, as some secular management training programs have done, merely to "teach" women how to behave more "assertively" (i.e., more like men). Women who either consciously or unconsciously behave in ways that communicate more power and authority are often ostracized or subjected to a range of more overt power behaviors intended to put them in their place.

Myths are constructed to explain the world and, more to the point, to try to control forces that are perceived as mysterious and threatening. It can be argued that at the deepest place in the collective psyche, the place that shapes the dominant masculine-constructed reality, Woman is such a force. Societal and cultural myths attempting to control women's power serve to lock unique, individual persons- both women and men-into stereotypes that are constricting, damaging, and ultimately death-dealing.

This leads to the last segment of my talk this evening, about the images of women that surround us in our culture. Women as imaged in Euro-American culture become icons for sale, valued as objects for their own sake-Barbie dolls, centerfolds, the silvery nude women on the mud flaps of trucks. These images instruct both men and women (perhaps especially during our formative teen years) what a "real" woman should be like: a young "It-woman" with

\footnotetext{
${ }^{53}$ Nancy Chodorow, The Reproduction of Mothering: Psychoanalysis and the Sociology of Gender (Berkeley: University of California Press, 1978).

${ }^{54}$ Dorothy Dinnerstein, The Mermaid and the Minotaur (New York: Harper \& Row, 1976).

${ }^{5 s}$ Carolyn Merchant, The Death of Nature: Women, Ecology, and the Scientific Revolution (San Francisco: HarperSan Francisco, 1980).

${ }^{56}$ For a more detailed discussion of the link between these theories and the prevalence of misogyny and violence against women, see Cooper-White, The Cry of Tamar, esp. 43-62.
} 


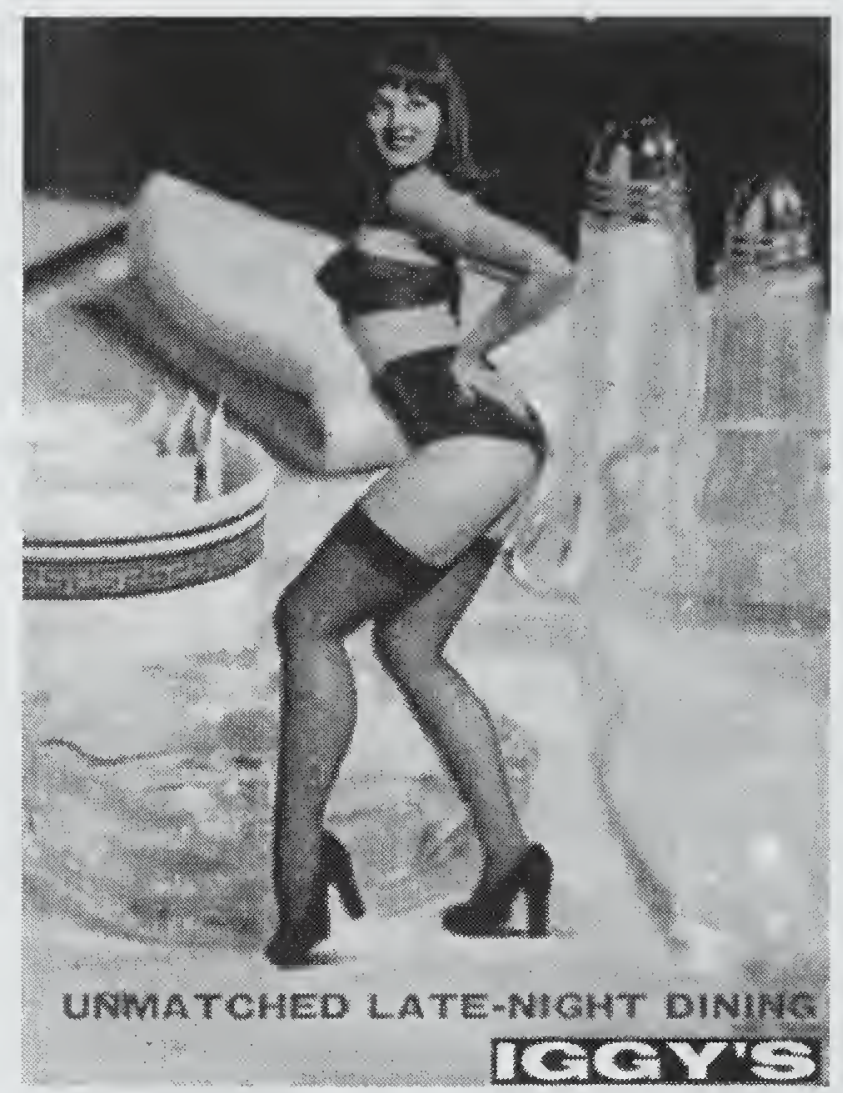

vacant eyes; large breasts that never sag; a frail, even anorexic waistline; and a body that complies uncomplainingly no matter what you do to it. If pornography is defined not merely by erotic content but by a standard of dehumanization and objectification of women, then a preponderance of mainstream media image of women are, in fact, pornographic.

Over many years, I have tracked images of women in a variety of mainstream news, fashion, and advertising publications, and the following themes emerge as just some of the forms of objectification that commonly appear:

- Women as actual objects (including objects for use, and trophies).

This postcard, distributed on the street for a now-closed diner in Berkeley, California, shows a woman as a utilitarian object on a table amid a variety of glassware. ${ }^{57}$ Her scale, combined with proximity to an ashtray, suggests a cigar, which might be consumed and then snuffed. Her stereotypically provocative black lingerie, along with other obvious Freudian symbols, such as the salt and pepper shakers, signify a fusion of sexualization and objectification.

\footnotetext{
${ }^{57}$ A good faith effort was made to locate the original publisher and request permission to duplicate. The original entity "Iggy's" no longer exists.
} 
The possibly ironic use of the vintage-style image does not negate its subliminal charge.

- Women as faceless, anonymous bodies or body parts.

This genre of images of women is prevalent in advertising, where nude or scantily clad women are shown with their faces obscured by their hair, by hats and veils, or cropped out altogether (for example, the New York Times 2004 Fashion Supplement, and 2006 SundayStyles Section). Considering this genre of images in light of philosopher Emmanuel Levinas's ${ }^{58}$ insistence that it is precisely the face of the other that illuminates his or her personhood and calls us to ethical responsibility, this obscuring of the face in public images can be understood only as a deliberate objectification of women and diminishment of the model's humanity.

- Ideal women versus bad women, including...

The bad woman as too powerful, for example, during the 2008 primary campaign, the advertising of plastic "Hillary Nutcrakers" where the candidate's thighs were the actual nutcracker, packaged in a box with captions "Is America ready for this nutcracker?," "Stainless Steel Thighs!" and "Cracks Toughest Nuts!"s9

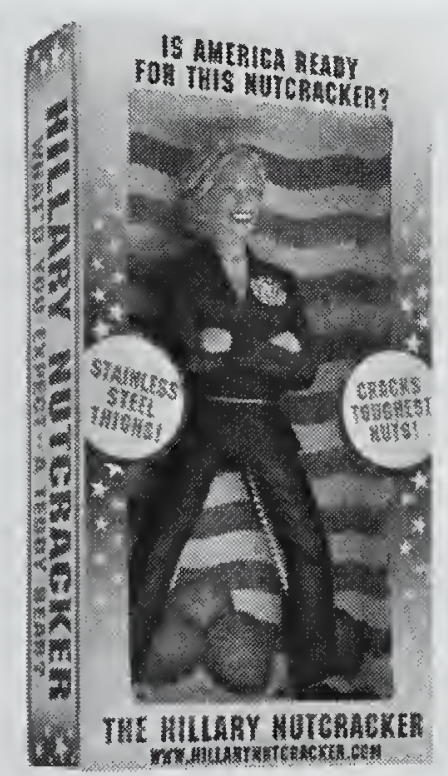

HILLARY NUTCRACKER

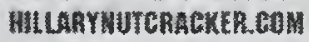

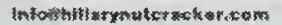

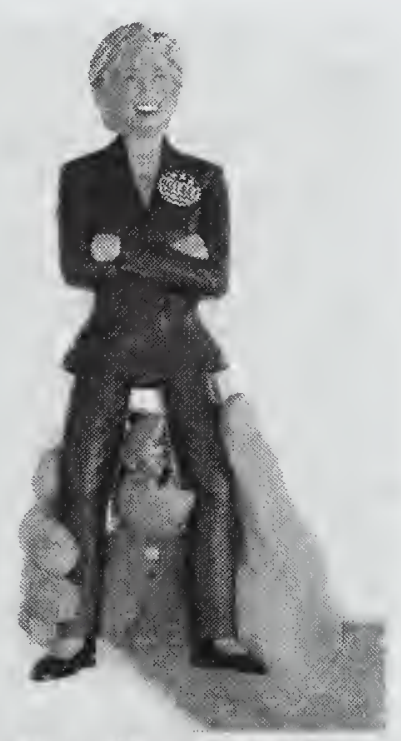

HILLARY NUTCRACKER HILARYMUTCRASKER. COH

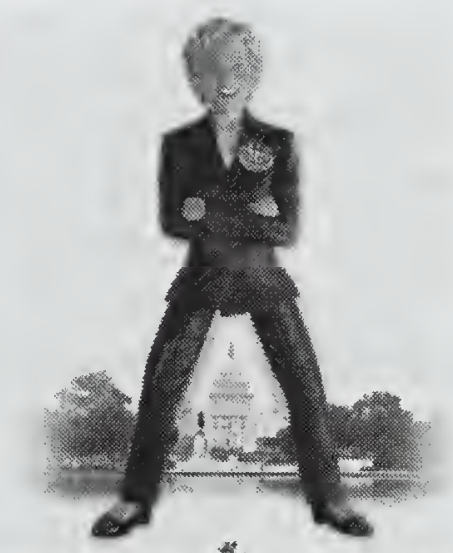

HILLARY NUTCRAGKER

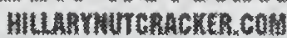

\footnotetext{
${ }^{58}$ Emmanuel Levinas, Totality and Infinity, trans. A. Lingis (Pittsburgh: Duquesne University Press, 1969).

${ }^{59}$ Permission to copy stipulated on http://www.hillarynutcracker.com/HillaryN-webimages. html.
} 
The bad woman as too old or too heavy (sexism fused with ageism and body size discrimination), for example, an ad for a Black \& Decker power mower depicting a gray-haired couple with the husband pushing the mower, the wife riding on it, with the caption: "A solution for those who still think a powerful mower has to be heavy."

The ideal woman as girl-woman, inviting incestuous fantasies. This genre accelerated after the Calvin Klein jeans advertising campaign showed a thenfourteen-year-old Brooke Shields with the caption, "Nothing gets between me and my Calvins," and subsequent use of teenage (or teenage-appearing) models in nude or nearly nude poses in mainstream advertising, echoing images of bondage of girls in underground pornography, ${ }^{60}$ for example, nude images of a gaunt Kate Moss for Obsession men's cologne.

- Women as animals or associated with animals: usually linked with racism. In an era when white women dominated the modeling profession, most images of women associated with animal skin or animal print clothing were African American women, often posed like wild animals (for example, a Glamour magazine "Do's and Don'ts" column with the title "Jungle Fever," featuring an African American model, and an Elle magazine full two-page centerfold showing a black woman in a reptile skin suit, crouched in a hissing catlike pose with the title, "On the Wild Side").

- Overt violence against women as. . .

Humor, for example, a 1970s New Yorker cartoon showing a husband and wife sitting on opposite ends of a couch watching TV, with the caption, "During the next commercial, I'm going to belt you one!" and ads for the movie "Faithful" showing the actress Cher tied to a chair with a red target on her chest, and the caption "After 20 Years of marriage she thought she was the target of her husband's affection. She was half right."

Eroticized bondage, for example, a pair of 1980s ads for Boucheron women's and men's perfumes, showed a blue-tone photo of a woman's headless torso from behind, posed passively with her hands bound by a heavy jeweled bracelet, in contrast with a full-color photo of a man's hand, clad in expensive jacket, white shirt cuff and gold watch, posed actively tossing the men's cologne in the air. The caption of the men's cologne further suggested a fusion of wealth and violence or criminality: "Boucheron, parfum pour Homme, an accomplice...."

\footnotetext{
${ }^{60}$ Diana Russell, Against Pornography: The Evidence of Harm (Berkeley: Russell Publications, 1993).
} 
Fashion. This genre of violent imagery has become increasingly explicit in mainstream media over the past two decades. For example, in the 2007 season of the television show America's Next Top Model, the women were photographed in grisly blood-splattered poses as victims of a variety of forms of murder; the photo shoot was praised by the show's host as "very high fashion." $" 61$

\section{Conclusion}

So what's our way out? If we do not live in denial, and we dare to say that as people of faith and as pastoral caregivers, we are called to be God's lovers and reconcilers, how can we face each other, how can we bridge our two separate realities, how can we ever talk to each other, talk about how much we care, talk about justice, talk about equality? How can we overcome our guilt, our shame, our rage and outrage? How can we as women and men talk to each other with tenderness and compassion ever again?

In this work of justice and compassion, I believe we are called to do four things:

First, to see and hear the truth. There are a lot of reasons why we don't want to. But perhaps the most compelling is that, in addition to the social inertia of which Judith Herman wrote, if we were to acknowledge the truth of all this violence, it would be too terrible. Who could bear to know it? We blame the victims, because then we can imagine that they did something to bring violence upon themselves, something that we are too smart or too "good" to do. If violence against women and sexual abuse are not as rare as we wish were the case-and many of you know from your own experience that they are not so rare-then we must face the truth that all women, and indeed, a great many men, are vulnerable. There is no "profile" that makes one woman more vulnerable to violation than another. We are all vulnerable. It is the mostly subliminal reality with which we live on a daily basis. (And even this subliminal awareness manifests differently between women and men. Think of yourself going into a deserted parking garage late at night. Most men will admit to being nervous about being mugged. Most women fear being raped.)

But the violence will not diminish unless we allow ourselves to see it, in all its tremendous proportions. And this goes to the heart of pastoral care. Pastoral care is much more than one pastor sitting and listening compassionately

${ }^{61}$ Images are available online at http://tv.yahoo.com/americas-next-top-model/show/35130/ photos/1\#goto_1, photos \#318-27. 
to another person, as valuable and core to our work as that may be. Pastoral care also involves creating a context for care that establishes safety, honesty, and a commitment to promoting justice and dignity throughout the entire community. And we not only provide care to individuals and couples and families but are called simultaneously to work in community to surround these individuals, couples, and families with a "holding environment" (to borrow from the British psychoanalyst D.W. Winnicott ${ }^{62}$ ), a holding environment of safety and justice that mirrors the Realm of God-which is our eschatological hope.

How do we actually do this? In very concrete ways this means doing and continuing to do what many of you and your local congregations have already begun in many places - putting out posters, flyers, and pamphlets conveying that the church - this church - intends to be a safe place for all people, and that biblical mandates and ecclesial policies are in place to ensure that safety and the true hospitality of the Gospel. ${ }^{63}$

It also means teaching and preaching and offering small groups and Bible studies, including lessons about sexual abuse and all forms of violence against women, so that our students and parishioners come to know and trust that this is a safe place, and we are safe people, to talk about what really happens in our lives. It means asking the right questions when we see bruises, warning signs, or frightened behaviors that signal us-sometimes at just a gut level - that something isn't right. It means being alert to the statistical reality that if one in five women are survivors of sexual abuse, one in three are raped, and as many as one half are battered, then proportionately as many women in our congregations - and here in our seminary communityare also victims and survivors. And they are waiting for a word of hope and solidarity and healing from us!

Second, we must name sexual abuse and exploitation as violence. When we first hear a woman tell us of her experience of sexual assault, battering, harassment, or sexual exploitation, we must remind ourselves to shift the focus off all the ways in which we are socialized to question her, doubt her, wonder what she did wrong, or what in her psychological makeup made her vulnerable. We must hold

\footnotetext{
${ }^{62}$ D. W. Winnicott, The Maturational Processes and the Facilitating Environment (London: Hogarth, 1965).

${ }^{63}$ For example, the former Commission for Women of ELCA (Evangelical Lutheran Church in America) in particular has created some excellent resources for this purpose.
} 
the focus on the one who is responsible- the person who chose to cross the line and to act with violence.

Third, we must move beyond helplessness, beyond sympathy, and even beyond anger, to justice for victims and survivors. This means entering into the public arena to challenge the images of women that distort women's full dignity and humanity. It means taking responsibility as a Christian community and as church leaders, to say to offenders that sexual exploitation and violation is never acceptable under any circumstances, and that we will stand for the righting of these wrongs-in our policies, and in our own personal relationships.

Finally, we are called to restore right relation, not just between individual men and women, and not in the sense of premature forgiveness or cheap grace, but in the sense of the whole community, the whole society. We are called to make connections between violence against women and all forms of violence-racism, heterosexism, classism, able-bodyism, and all forms of oppression that serve to maintain structures of power and privilege at the expense of the majority of the planet's people and creatures.

Taking all this into consideration, then, our goal is not a gender-blind pastoral care, in which we simply try to treat women and men alike, nor is it our goal to be color-blind, or "neutral" toward all the various differences of an individual's culture, identity, age, sexuality, or physical ability — but a gender- and culturalsensitive pastoral care that recognizes all the unique particularities of each person's life and celebrates them as precious in God's sight.

The philosopher Martin Buber wrote, "Inscrutably involved, we live in currents of universal reciprocity." "It is this "I-Thou" relationship that refuses to brand any person as an "It" and replaces aggression and domination with relationality, truth-telling, and care.

Objectification is the root of all violence. Thank God, we are now talking to one another about these things-in seminaries like this one and in the wider church. It is a great sign of hope to me that, indeed, our religious communities - and we, here today, gathered as a faithful community of pastors, educators, and especially those of you who are on the cutting edge, preparing yourselves for lay and ordained ministry - we are at many times, and in

${ }^{64}$ Martin Buber, I and Thou, trans. W. Kaufman (New York: Charles Scribner's Sons, 1970), 67. 
many places, breaking silence, and taking up our calling: to speak truth to power in love. In speaking this truth, we reverse patterns of privilege and discrimination, patterns of domination and objectification, and enter into possibilities for true relationship. This is the heart of all pastoral care. It is only as we move out of denial and into genuine relatedness, I believe, in mutual concern and agape love, that we will find the means to safety and community-for all people, women and men alike. 


\section{Getting Calvin Right: How Karl Barth Changed Our Reading of the Reformer}

by Christopher Elwood

Christopher Elwood is Professor of Historical Theology at Louisville Presbyterian Theological Seminary, in Kentucky. Dr. Elwood is author of The Body Broken: The Calvinist Doctrine of the Eucharist and the Symbolization of Power in Sixteenth-Century France (Oxford University Press, 1999) and Calvin for Armchair Theologians (Westminster John Knox, 2002). He gave this lecture on January 23, 2009, as part of the Calvin colloquium titled "Calvin and the Church Todoy: Ecclesiology as Received, Changed, and Adapted," held in the Cooper Conference Room.

$\int$ ohn Calvin received a great deal of attention, from a broadening circle of theologians and other scholars, in the course of the twentieth century. The reasons for this are no doubt many. We could examine all sorts of developments in society, culture, or politics, at key points in the last one hundred years, to help explain why readers might be encouraged to look again at the Reformer of Geneva. But if we had to assign responsibility to a single individual for the rise in Calvin's profile, without a doubt we would have to point to Karl Barth.

The strangeness of that claim is perhaps not immediately apparent. Barth was not himself a church historian and he claimed no special expertise as a Calvin scholar. It is true that he taught on Calvin several times, was keenly interested in Calvin's biography, his personality, and his theology, chiefly as he found it in the Institutes of the Christian Religion. Calvin made several key appearances in the extended discussions of Barth's magnum opus, the Church Dogmatics, often as a significant ally, occasionally as an honored elder colleague who required correction. But Barth frequently deferred to his brother, the Calvin specialist Peter Barth, as 
one more capable of working out the details of some important concept in Calvin, owing to what Karl called his own "limited knowledge of the subject."

Barth's key importance for the study of Calvin had less to do with his gifts for historical-theological scholarship than with the excitement his pathbreaking dogmatic theological writings created for a new generation of theological readers. After the First World War, in a revolutionary moment, Barth referred to several important historical voices, and Calvin in particular, as deserving of a fresh hearing. For those who paid attention - and their numbers grew significantly in the 1920 s and 1930s - the Genevan reformer seemed suddenly important. Calvin became relevant for genuinely contemporary theological and cultural reflection and not simply for a narrowly confessional theology. One might say that Barth rescued Calvin from the hold, on the one hand, of traditional Calvinists and, on the other, of church historians-an accomplishment both camps have ever since had trouble forgiving.

Barth emerged on the theological scene very shortly after the end of World War I, when he published his epoch-making commentary on Paul's Epistle to the Romans. It appeared first in 1919 and in a much revised edition in 1922. ${ }^{2}$ The fame (or notoriety) this work achieved led to Barth's moving, in 1921, from the pastorate in the Swiss village of Safenwil and taking up a call to be professor of Reformed theology at the University of Göttingen in Germany. He would later take up positions at Münster and Bonn; and then, before the outbreak of the World War II, he would return to Basel, in his native Switzerland, for the remainder of his career (he retired in 1962). But it was in Göttingen, his first academic appointment, that Barth was given the early opportunity to delve deeply into Calvin and the Reformed tradition.

Barth's early theological forays are usually described in explosive metaphors. To say that his first writing "fell like a bomb" on the theologians" playground, as Tübingen theologian Karl Adam did in 1926, gives one a sense of what Barth's way of theological thinking and expression must have felt like to an already shellshocked postwar European intellectual establishment. ${ }^{3}$ It came as a sharp challenge to an old theological order; but to a new generation it seemed a bold invitation, perfectly suited to the crisis of the time, to hear a new, fresh, indeed revelatory word.

It is little surprise, then, that this should have been dubbed the "theology of crisis." The radical shift in the zeitgeist meant that everything was up for grabs,

${ }^{1}$ Karl Barth, "No! Answer to Emil Brunner," in Natural Theology, trans. Peter Fraenkel (London: The Centenary Press, 1946), 105.

${ }^{2}$ The Epistle to the Romans, trans. Edwyn C. Hoskins (London: Oxford University Press, 1933).

${ }^{3}$ Joseph Mangina, Karl Barth: Theologian of Christian Witness (Louisville: Westminster, 2004), 3. 
and there surely could be no return to the routine of the established liberal tradition of so-called scientific theology.

The response in North America was similar, although delayed by almost a decade. One of Barth's first English-language translators, Douglas Horton, commented on "the surprise, the joy, the refreshment" produced by a first dipping into Barth's writing. Here, said Horton, was a clear and vital alternative to the "kind of desiccated humanism, almost empty of other-worldly content" that passed, in that day, for theology. In Barth, Horton found "in a thoroughly modern form but in all its ancient strength-a resurgence of the Calvinism of Calvin." ${ }^{4}$ Many shared the perception. The theologian and ethicist $\mathrm{H}$. Richard Niebuhr would remember the 1930s as the time when he and others like him discovered Barth, were largely converted to his way of thinking, and "turned back to the "Great Tradition"" of theologians, among whom Calvin was especially prominent. ${ }^{5}$

Barth's redirecting of theological reading was, naturally, no neutral attempt to see what Calvin and other early Protestant theologians might have to say to the world of the present. Barth came to Calvin with his own theological agenda, a perspective that shaped what he would find in the Genevan reformer. In this essay I propose to examine the uses Barth made of Calvin, as he read and wrestled with his contributions and sought to articulate his own positions more clearly - whether as natural extensions of Calvin's insights or as corrections of his errors. To assess Barth's reading and its ongoing legacy, I will first explore Barth's positive use of Calvin ("Why Calvin Was Right"); then examine some key areas in which Barth argued with Calvin's positions and sought to go a somewhat different way, focusing especially on Barth's account of baptism ("Why Calvin Was Wrong"); and, finally, I will consider a variety of ways in which Barth's own reading of Calvin and his powerful influence over Calvin scholarship has been received ("Was Barth Right?").

\section{Why Calvin Was Right}

At the start, there is a complication. Despite my best efforts to keep this discussion focused on two theological minds-Calvin's and Barth's--I find I have to bring in a third figure, also a pastor and theologian in the Reformed tradition, namely, Friedrich Schleiermacher. For it is Schleiermacher whom Barth

\footnotetext{
${ }^{4}$ Douglas Horton, "Foreword," in The Word of God and the Word of Man, Karl Barth (Gloucester: Peter Smith, 1978), 1-2, 6.

${ }^{5}$ H. Richard Niebuhr, "Reformation: Continuing Imperative," in "The Responsibility of the Church for Society" and Other Essays by H. Richard Niebuhr, Kristine A. Culp, ed. (Louisville: Westminster John Knox, 2008), 138-41.
} 
identified, at the very beginning of his public career and even up to the year of his death, 1968, as his principal theological adversary. Barth insisted that Schleiermacher bore responsibility for setting theology on a very interesting but ultimately disastrous course when he inaugurated a modern theology grounded in the religious experience of the human person. Schleiermacher's attempt in the early nineteenth century to speak theologically out of religious feeling, or the God-consciousness that was a component of every person's experience, shaped traditions of European academic theology ever after. In fact, it was a form of Protestant liberalism ultimately derived from Schleiermacher that had shaped Barth through his theological education and that formed his early ministry. But during the years of the First World War, Barth became convinced that Schleiermacher's approach was theologically untenable. It led to an "anthropologizing of theology." Beginning with human experience, all one could speak of, finally, was humanity. Schleiermacher had not grasped "that one can not speak of God simply by speaking of man in a loud voice," as Barth said in 1922.

One of the consistent tasks of Barth's early theology was to make quite plain that Schleiermacher's approach was not suited to a theology worthy of the name. It was in the service of this polemical task that Calvin became particularly helpful to Barth, because he believed that Calvin posed a stark, Reformation alternative to the liberal Schleiermacher. In Calvin he found an emphasis on the majesty and transcendence of God, the development of a theology centered on God's self-revelation and our response in obedient faith, as well as a christocentric focus. Let us look briefly at each of these in turn.

\section{GoD's RADicAl OTHERNESS}

Barth's early writings are known especially for their emphasizing God's wholly otherness, the "infinite qualitative distinction" between God and humanity, Creator and creation, time and eternity. ${ }^{8}$ Barth was convinced that Schleiermacher and his disciples had obliterated this difference in their assumption of some basic, organic connection between human experience and divine reality. Calvin was cited by Barth as a theological teacher who saw correctly a biblical theme--the majesty and transcendence of God-and consistently defended it against the religious and secular culture of his day. Medieval religion, thought Barth, placed humanity - human history, traditions,

\footnotetext{
${ }^{6}$ "Concluding Scientific Postscript on Schleiermacher," in The Theology of Schleiermacher, by Karl Barth, ed. Dietrich Ritschl, trans. Geoffrey W. Bromiley (Grand Rapids: Eerdmans, 1982), 269.

7 The Word of God and the Word of Man, 195-96.

${ }^{8}$ The Epistle to the Romans, 10.
} 
human wisdom - at the center, usurping the proper place of God. Against this, Calvin stressed antithesis; not simply Luther's antithesis of faith and works, but a whole series of polarities: "Creator and creation, God's truth and man's invention, God's law and the church's law." Calvin's struggle against a confusion of the transcendent with the immanent served as an analogue to Barth's own struggle against Schleiermacher and liberalism's modernizing project. To make the point crystal clear, Barth suggested that Calvin was a critic of the theologically domesticating tendencies of the modern moment-even though the sixteenthcentury reformer was clearly premodern. To establish this, Barth simply had to point to Renaissance humanism, the cultural movement with which Calvin was intimately familiar, as an early anticipation of the modern focus on the human, the world, and history. Calvin and the early Reformed were careful to "guard their borders," and maintain a vital sense of God's majesty, precisely so as to resist the dangers posed by this modernizing experiment. ${ }^{10}$ And so characterizing Calvin as the Reformation theologian par excellence of God's otherness and majesty helped Barth underline a basic polemical point: Schleiermacher and Protestant liberalism had no legitimate standing in the tradition that stemmed from the Reformation in general and Calvin in particular. ${ }^{11}$

\section{A Theology of Revelation}

Barth felt a close kinship with Calvin and the Reformation based on a shared interest in keeping all theological reflection closely tethered to the reading and interpretation of scripture. For Calvin, one approached scripture with the confidence that there one would receive God's message to us, hearing in the word God's "voice as that of [our] Shepherd, and [regarding] any other voice as that of a stranger [John 10.27]."12 The problem presented by theological liberalism was that it had lost this Reformation sense of a direct and immediate encounter with God's word in scripture-partly because of the impact of Biblical criticism. In his Romans commentary Barth ventured a shocking claim: one could actually adopt the view of biblical inspiration expounded by Calvin without rejecting the claims of biblical criticism. ${ }^{13}$ Calvin himself, said Barth, was no biblical literalist, and even modeled for later interpreters a way of holding together reverence

\footnotetext{
${ }^{9}$ The Word of God and the Word of Man, 250.

${ }^{10}$ Karl Barth, The Theology of the Reformed Confessions (Louisville: Westminster John Knox), 209-10; Karl Barth, "Thoughts on the 400th Anniversary of Calvin's Death," in Fragments Grave and Gray (London: Collins, 1971), 106.

"See The Word of God and the Word of Man, 195-96, 250.

${ }^{12}$ Responsio ad Sadoleti Epistolam, in Joannis Calvini Opera Selecta, Peter Barth and Wilhelm Niesel, eds. (Munich: 1926), I, 465.

${ }^{13}$ The Epistle to the Romans, 1, 18-19.
} 
for the word and a critical sensibility. He employed a "critical freedom of exegesis ... in masterly fashion." 14

It is at this point that Barth's reading of Calvin signaled a distance from inerrantism, or fundamentalist approaches to scripture, in his developing doctrine of revelation. The Christian must attend to God's word as one hears it in scripture. But he rejected the idea that scripture and revelation were exactly, or functionally, equivalent. The word of God, as Barth said, is within the Bible. One should not confuse the all-too-human words of scripture with the Divine Word conveyed through them. ${ }^{15}$

A key corollary of this understanding of revelation had to do with its reception: the notion that God's Word comes to human beings, and is received, in what Barth characterized as obedient faith. Barth was fond of citing Calvin's dictum "all right knowledge of God is born of obedience" to establish the point that we have no knowledge of God outside the circle of faith. ${ }^{16}$ Theology, therefore, cannot begin (as it had with Schleiermacher) with the human situation, with our questions, our experience, or our understanding. It can only attend to the strange and alien word, the Good News that is God's own self-disclosure.

\section{Christological Concentration}

By the end of the decade of the 1930s, Barth had produced a refinement of this approach that he called "Christological concentration." This was the view that, in his words, "Christian doctrine, if it is to merit its name ... has to be exclusively and conclusively the doctrine of Jesus Christ - of Jesus Christ as the living Word of God spoken to us men." ${ }^{17}$ Theology, then, would have to be "christocentric," in the sense that nothing could be asserted that was not founded on God's gracious self-disclosure in Christ. Barth's christocentrism was on display in the Declaration of Barmen of 1934, of which Barth was the principal author: "Jesus Christ ... is the one Word of God, whom we have to hear and whom we have to trust and obey in life and in death." ${ }^{\prime 18}$ Barmen was the Confessing Church's repudiation of the German Christian Movement and its attempt to align the church and Christian witness with the nationalist and racist ideology

\footnotetext{
${ }^{14}$ The Epistle to the Romans, 19.

${ }^{15}$ See Barth's 1922 essay, "The Strange New World within the Bible," in The Word of God and the Word of Man.

${ }^{16}$ Institutes, 1.6.2; see Church Dogmatics, I/1, 18.

${ }^{17}$ Karl Barth, How I Changed My Mind (Richmond: John Knox, 1966), 43.

${ }^{18}$ See Barth's discussion of the first article of the Barmen Declaration in Church Dogmatics II/ 1,171 .
} 
of the newly ascendant Nazi party and its German "Third Reich." Barth maintained that Christians could legitimately attend only to God's revelation in Jesus Christ for their confession and their ethics. Calvin's theology, in his view, firmly resisted any appeal to a competing source of revelation-be it personal, national, or ethnic experience; nature or created orders; the gift of reason; or the capacity for philosophical speculation.

Because this theological question involved a struggle for the very identity of the Church and Christian witness in Nazi Germany, Barth took it as a direct insult when his close colleague, fellow Swiss theologian Emil Brunner, argued for a different reading of Calvin. ${ }^{19}$ Brunner thought that Calvin's theology leaves room for a Christian natural theology because he speaks plainly of God's revelation in creation and of a surviving remnant of the image of God in fallen humanity. In God's creation, then, there is a "point of contact," a human (and a cultural) capacity for receiving the Good News. ${ }^{20}$

In his well-known, angry Nein!-his 1935 retort to Brunner-Barth argued forcefully that scripture and Calvin were on the same side, against any natural theological approach that would attempt to build upon creaturely orders or historical experience. Divine revelation was absolutely unique, given only in and through Christ. The freedom of God in revelation had to be respected, as did the freedom of the word of God from ideological corruption.

The debate with Brunner yielded what was perhaps the clearest expression of Barth's fundamental objection to nineteenth-century liberalism, made all the more clear because it involved ethical questions of obvious public import. Whether in this debate he had Calvin right was, of course, open to question. In 1936, A. C. McGiffert Jr., a North American observer from the liberal camp, insisted that Barth's theology was Calvinism to be sure, but it was Calvin grossly exaggerated. Calvin's practical orientation would not have allowed him to succumb to Barth's "ruthless splitting apart of reality" - his insisting on an extreme discontinuity between God and humanity, "transcendence and immanence ... eternity and time ... faith and reason," and so forth. ${ }^{21}$ Others, however, would weigh in powerfully on the other side. Wilhelm Niesel's 1936 Die Theologie Calvins (or The Theology of Calvin, which, in English translation would by the 1950s become a standard seminary introduction to Calvin's theology) dealt with the whole question of revelation with Barthian directness: "Whoever ...

\footnotetext{
${ }^{19}$ Barth, "No! Answer to Emil Brunner," 105.

${ }^{20}$ Emil Brunner, "Nature and Grace," in Natural Theology, 15-64.

${ }^{21}$ Arthur Cushman McGiffert, "Is Calvin Coming Back?" Christendom 1 (1936): 320-22.
} 
discovers in [Calvin's] writings a theologia naturalis [a natural theology] can hardly be regarded seriously as a scholar. ${ }^{, 22}$

Niesel's Calvin textbook was a sign of things to come. By midcentury, Barthian readings of Calvin would become the dominant representations of the Reformer. Here is a sample from Strasbourg theologian François Wendel, in 1950, explicating the (somewhat open-ended) opening line of the Institutes, "Nearly all the wisdom we possess, that is to say, true and sound wisdom, consists of two parts: the knowledge of God and of ourselves. ${ }^{123}$ Calvin announces at the very beginning, says Wendel, "one of the essential principles of the Reform: the absolute transcendence of God and his total 'otherness' in relation to man. No theology is Christian and in conformity to the Scriptures but in the degree to which it respects the infinite distance separating God from his creature and gives up all confusion, all 'mixing,' that might tend to efface the radical distinction between the Divine and the human." ${ }^{24}$ Wendel did not argue for this reading, as it must have seemed to him the obvious reading - a mark, perhaps, of the extent to which Barth's view of things, his constructive and polemical habits of thought and theological turns of phrase, had permeated discussions of the reformer.

\section{Why Calvin Was Wrong}

Calvin was, of course, not always employed by Barth simply as a theological ally and supporter. Especially as Barth moved deeper into the content of his Church Dogmatics, he increasingly used the Reformer as an object lesson, to show how a well-intended project could go astray when some basic dogmatic (or exegetical) principle was not attended to.

\section{A Summary Assessment}

Barth's most concise assessment of Calvin was issued in 1964, in the year of another Calvin anniversary - the commemoration of 400 years since the Reformer's death. In a brief essay, Barth made his affection for Calvin apparent. But he also identified areas for criticism. Calvin's understanding of the doctrine of election is mentioned as a chief error: he construed the covenant too narrowly, assuming that the vast majority of humankind lay outside the grace and mercy

\footnotetext{
${ }^{22}$ Wilhelm Niesel, The Theologv of Calvin, trans. Harold Knight (Philadelphia: Westminster, 1956), 40.

${ }^{23}$ Institutes, 1.1.1.

${ }^{24}$ François Wendel, Calvin: Origins and Development of his Religious Thought, trans. Philip Mairet (New York: Harper \& Row, 1963), 151.
} 
of God. Like Schleiermacher before him, Barth took Calvin's statement of the doctrine seriously and even highlighted election as a key element of dogmatics, but he could not agree with the exclusionary casting Calvin had given the doctrine. He was also critical of Calvin's focus on rigorous discipline, which, he said, imposed "a certain atmosphere of gloom on the whole matter." Finally, the Genevan reformer was faulted for a Platonic tendency, an inclination to pull apart soul and body, heaven and earth, in a way that was "life denying." 25

One senses in this brief catalogue of Calvin's theological failings evidence of a basic difference in temperament: Barth sees Calvin as too melancholy, unable to give adequate voice to the "good news" of love, and hope, and (above all) joy. Joy, for Barth, was a note that had to be sounded especially clearly, and Calvin was seemingly not up to the task. Christoph Barth-Karl's son-said, somewhat later, that he learned from his father's example that "theology ... must be the most joyful, the most exciting of all sciences," a conviction well-represented in Barth's love of Mozart and the composer's "calm joyfulness."26

\section{Baptism and the Church}

Barth did not refer in this essay on Calvin to an area of doctrinal disagreement that has caused many inheritors of Calvin's sacramental thought significant headaches. I am referring to Barth's mature understanding of baptism, the view of the sacrament that emerged with particular clarity in the years following World War II. ${ }^{27}$ In his early theology, Barth's view was virtually indistinguishable from Calvin's: baptism was a sacrament of grace, the sign and seal of God's redemption in Jesus Christ. But he gradually came to see that Calvin's view, while it had some valuable and commendable components, was, considered as a whole, "hopelessly confused."28 Barth's rethinking of baptism coincided with the development in more precise form in his dogmatics of a paradigm of covenantal partnership. As always, Barth emphasized the initiative of God's free and gracious act in revelation and reconciliation; but he came to mark out more clearly the way in which divine grace calls forth a free, human response. Here lay the problem: the Reformation doctrines of baptism articulated by the

\footnotetext{
${ }^{25}$ Barth, "Thoughts on the 400th Anniversary of Calvin's Death," $108 \mathrm{f}$.

${ }^{26}$ Donald K. McKim, ed., How Karl Barth Changed My Mind (Grand Rapids: Eerdmans, 1986), 6; Barth, "The 'Un-Mozartean' Swiss," in Fragments Grave and Gray, 52.

${ }^{27}$ See Daniel Migliore, "Reforming the Theology and Practice of Baptism: The Challenge of Karl Barth," in Toward the Future of Reformed Theology, ed. David Willis and Michael Welker (Grand Rapids: Eerdmans, 1999).

${ }^{28}$ Karl Barth, The Teaching of the Church Regarding Baptism, trans. Ernest A. Payne (London: SCM Press, 1963), 49.
} 
magisterial reformers Luther, Zwingli, and Calvin all emphasized infant baptism and rejected believer baptism. Barth had become convinced that infant baptism had no solid exegetical grounding and that its dogmatic warrants were insufficient. Baptism is not (and should not be) a coercive act-either of God or the church-but rather a free and responsible human act, evidencing decision and confession. ${ }^{29}$

Calvin had produced several warrants for infant baptism, and Barth rejected each of these as unconvincing. Indeed, Barth did not think Calvin was himself convinced and believed that he was simply engaging in special pleading for maintaining a traditional practice. Why would he do this? Because Calvin reflected the habitual commitment of a historically Christian culture to the paradigm of the church standing at the center of society, in a Constantinian arrangement-society was thought to be the corpus christianum, the Christian body in sociological form. The price of maintaining this arrangement was a rite that, in Barth's view, stifled "the free movement and control of the Holy Spirit" in calling forth a free response from human beings, and thus corrupted the calling of the church. ${ }^{30}$

Especially troubling to Barth was the Reformer's handling of the issue of the (human) faith that receives the divine promise baptism announces. In the case of infant baptism, whose faith receives God's gracious promise? It cannot be, in any immediate sense, the faith of the child, who is not capable of a faithful response at the time of the sacrament's administration. So Calvin and others were inclined to point to the faith of the parents, the family, and the community as standing in for the infant in his or her present incapacity, and they spoke of the nurturing of a seed of faith in the child that would bear fruit in the future. Nonsense, said Barth. Baptism is about God's act and a human response, and the one who is to respond must be the baptized. Calvin and others were mistaken to suggest that an obligation to respond to God's grace, in the form of nurture, is laid upon the community as a whole. ${ }^{31}$ This mistake ended up perpetuating an erroneous view of the Christian life and a false view of the church as the church of the majority - or the national church; and it preserved an unhealthy arrangement in which being or becoming a Christian meant no more and no less than assuming one's place as a citizen of a national polity.

\footnotetext{
${ }^{29}$ Ibid., 50.

${ }^{30}$ Ibid., 51.

${ }^{31}$ Barth, The Teaching of the Church Regarding Baptism, 50.
} 
Baptism may at first seem a small affair. But Barth's disagreement with Calvin opens up a window on a larger, ecclesiological difference - and one that is particularly important to take note of as we are assessing Barth's relationship to and interpretation of Calvin.

Both Calvin and Barth understood the church to be a community called by God, in a basic sense founded upon God's decision and focused upon God's redemptive work in Christ. Both emphasized the need for this community to be what Barth referred to as "a healthy Church." But for Barth, this would mean, as a practical matter, that the church would be, as he said, "in the minority, perhaps in the very small minority." And its minority status would be a consequence of the freedom of response that would characterize its members' entry into the community: it would be a gathering of those who had genuinely responded to God's grace in Christ. ${ }^{32}$ Calvin's view of the church was concerned with maintaining the church's integrity (or, in classical terms, holiness) in tension with a commitment to catholicity. Calvin believed, in other words, that the church ought to be inclusive in the sense of incorporating the many. This is the view that, as we have seen, Barth rejects as a wrong-headed perpetuation of Constantinianism, or "Christendom"- the church as "the multitude of the baptized," in Barth's disparaging characterization..$^{33}$

The logic of their different positions is perhaps best experienced if we compare images of the church toward which each was inclined. Calvin adopted Cyprian of Carthage's metaphor of the Church as nursing mother of the faithful. The church served as the matrix or environment (the mother's "bosom," in Calvin's phrase) for the Spirit's work of gradual, gracious transformation. Scholastic and domestic metaphors come to mind as one reads Calvin on the church. It is the "place" in which we have access to the best instruction, nurture, correction-all (one hopes) as an expression of divine love and care. Just as in school or home, regular, routine practices of care by formation (preaching, sacraments, teaching, and discipline) are important in Calvin's model. ${ }^{34}$ With Barth the images are quite different: the church is not a place or space or environment but a happening, an "event." We are not gathered into the church for the purpose of formation so much as to be sent out with a task to accomplish. This task centers exclusively on witness to Jesus Christ. In a reflection of Barth's christocentrism, the church is defined wholly by virtue of its capacity to make Christ evident: it is the "earthly-historical form of Jesus Christ." So, for Barth, the church is not

\footnotetext{
${ }^{32}$ Barth, The Teaching of the Church Regarding Baptism, 53.

${ }^{33}$ Ibid., 51.

${ }^{34}$ Institutes, 4.1.
} 
principally about the business of nurture but rather of proclamation. As we've seen, he had little patience with Calvin's more communitarian concentration; the church is focused on a discrete task - witness-and is born out of the individual encounter with God's grace, an encounter that demands personal, committed response. In emphasizing the church as event, Barth played down the notion that the church and its practices require a good deal of attention. Barth's favorite visual image for making this basic point was the crucifixion scene in Matthias Grünewald's Isenheim Altarpiece. In the image, John the Baptist, standing to the right of the crucified Jesus, points, with a very long finger, away from himself and toward the Christ. John serves well as an emblem of the church, in Barth's understanding. The church was truly constituted, he said, "only as it points beyond itself" and to Jesus Christ. ${ }^{35}$ In other words, in contrast to Calvin, Barth was not inclined to focus on a continuous and routine existence and being of the church. One could ask with Calvin what the church is, or where it is, but it was more to the point, from Barth's perspective, to ask when the church is. The Church is when, and only when, Christ is proclaimed and made known. ${ }^{36}$

I have lingered a bit longer over this aspect of Barth's ecclesiological thought, because I believe the disagreement of these two over the church signals to us distinctive theological criteria Barth brought to his reading of Calvin. In Calvin he discerned a correct, and biblical, concentration on God's transcendent freedom and God's self-revelation in Christ. But Calvin's sacramental emphases, apparent in his explication of baptism and the Lord's Supper and more broadly in his treatment of the church, appeared to compromise divine freedom and did violence to the key (and also biblical) notion of human freedom and responsibility. Thus, Calvin started on the right track with his basic insight into God's wholly other freedom but veered off course when it came to discussions of the church and its practices. Calvin could serve as a theological guide up to a certain point, but Barth believed he had to go in a very different ecclesiological direction so as to do justice to what he saw as the more fundamental element in Calvin's theology.

This interpretive procedure opened Barth up to all sorts of criticism. Was he emphasizing divine transcendence in a way that excluded a certain incarnational emphasis (at least with respect to the church and sacraments)? Had he failed to appreciate Calvin's emphasis on the Holy Spirit's work within the gathered

\footnotetext{
${ }^{35}$ Church Dogmatics, IV/1, 623.

${ }^{36}$ This is an example of what George Hunsinger has identified as Barth's actualism. See his How to Read Karl Barth: The Shape of His Theology (New York: Oxford University Press, 1991), 30-32.
} 
community, and the human means (and routine gestures) through which grace is conveyed and the church built up? And, connected to this, had he perhaps downplayed the trinitarian aspect of Calvin's theology — an aspect that gave form to Calvin's reflections on the formation of the church by the work of the Spirit? Had Barth's instrumentalist account of the church-always focused on its work of public proclamation - substituted a stereotypically "masculine" image of the church doing important public business for Calvin's more "feminine" imagery of the church tending to the everydayness of mundane but equally important needs? Questions such as these, raised in recent studies of Barth and Calvin, may help us see more clearly how Barth's critique of Calvin exposed elements of a theological orientation that was perhaps even more widely at variance with Calvin's than Barth himself recognized or acknowledged. ${ }^{37}$

\section{WAS BARTH Right?}

These last comments have already taken us into the third area of this essay, namely, a consideration of how Barth's use and reading of Calvin was received, especially in those ecclesial and theological communities that had a special stake in this interpretation. The question, in other words, is: Was Barth right?

Right or wrong, the majority in the audience, regardless of their theological convictions, acknowledged that Barth brought readers to Calvin-to engage his thought directly. Even Barth's most vigorous opponents acknowledged as much.$^{38}$ And there were opponents. Many of these were conservative Calvinists who had inherited the mantle of the old Princeton Theology of Charles Hodge and his successors. For this audience, Barth deviated directly from Calvin on too many points. ${ }^{39}$ Barth, and his followers perhaps more consistently, tended to

\footnotetext{
${ }^{37}$ See the discussion in Joseph Mangina, Karl Barth: Theologian of Christian Witness, 154-56, 163f. For a trinitarian reading of Calvin's ecclesiology, see Philip W. Butin, Revelation, Redemption, and Response: Calvin's Trinitarian Understanding of the Divine-Human Relationship (New York: Oxford University Press, 1995), 98-106. Amy Plantinga Pauw addresses ecclesiological themes that distinguish Barth from Calvin in "Qohelet's Word to the Missional Church," unpublished paper, 2008; and "The Church as Mother and Bride in the Reformed Tradition" in Many Voices One God: Being Faithful in a Pluralistic World, Walter Brueggemann and George Stroup, eds. (Louisville: Westminster John Knox, 1998). The themes of Christian nurture and evolutionary growth in faith, arguably a vital component of Calvin's view of the church, were developed by liberal Protestants of the nineteenth century, including Schleiermacher and Horace Bushnell (Christian Nurture), a fact that may account for Barth's inclination in another direction.

${ }^{38}$ See Cornelius van Til, The New Modernism (Philadelphia: Presbyterian and Reformed, 1946); John H. Gerstner, "Calvinism Four Hundred Years After," in John Calvin: Contemporary Prophet (Grand Rapids: Baker, 1959).

${ }^{39}$ Gerstner listed among these deviations Barth's modal trinitarianism, his denial of infant baptism, emphasis on the universality of election, and an ethic that discerned an ameliorative rather than a vindictive purpose in the divine justice: Gerstner, "Calvinism Four Hundred Years After," 13-14.
} 
stress a discontinuity between Calvin and scholastic Calvinism, or the Calvinist orthodoxy that took root in the seventeenth century. That particular interpretive move had the aim of undercutting conservative readings of Calvin, because it questioned whether the orthodoxy conservatives embraced would have been authorized by this important source of Reformed theology. ${ }^{40}$ Even where Barth held himself up as agreeing with Calvin-as, for example, on scripture and inspiration - there were what appeared to conservatives to be dangerous accommodations to liberalism. (Was the Bible really the word of God, in Barth's understanding?) From the conservative standpoint, Barth seemed to stand nearer to Schleiermacher than he maintained. ${ }^{41}$

But there were many converts, of course. When Barth, after his retirement, visited Princeton Theological Seminary in 1962, not one representative of the old Princeton Theology remained, and his reception was exceedingly cordial, as many members of the faculty had been already profoundly shaped by his thought (even if they were not all, to a person, "Barthians"). Today, forty-seven years after Barth's visit, one might truthfully say that the new Princeton theology is deeply Barthian in inspiration, as the Seminary has done a fine job of attracting a startling number of theologians who have focused their own work on Barth's intellectual history, his theology, or the implications of Barth's concerns for contemporary challenges. ${ }^{42}$ To the north of Princeton, in New Haven, Connecticut, Barth had an equally significant impact in the emergence of the "Yale School" of postliberal theology, formed by Hans Frei and George Lindbeck and carried on by their students, who include some important interpreters of Calvin. ${ }^{43}$ Few of these "converts" would argue for a simple preservation of the content of Barth's theology. But they were, or are, convinced that theological work today will appropriately reflect the agenda Barth articulated.

I have mentioned that Barth's reading of Calvin had come to dominate theological texts in the middle part of the twentieth century. This fact led to murmurings

\footnotetext{
${ }^{40}$ See, for example, Basil Hall, "Calvin against the Calvinists," in John Calvin, Gervase Duffield, ed. (Grand Rapids: Eerdmans, 1966).

${ }^{41}$ Barth's orientation was not sufficiently Calvinist, in John Gerstner's view. Gerstner, "Calvinism Four Hundred Years After," 14. A distancing from "Calvinism" was precisely what Barth himself intended, however, since he viewed the perpetuation of a particular, Calvinistic, school as a violation of Calvin's spirit. See "Thoughts on the 400th Anniversary of Calvin's Death," 105, 110.

${ }^{42}$ This list includes, among current Princeton faculty, George Hunsinger, Bruce McCormack, Daniel Migliore, William Stacy Johnson, and Darrell Guder.

${ }^{43}$ At the center of the Yale School were Hans Frei, George Lindbeck, and David Kelsey, whose approaches have influenced readings of Calvin in a number of scholars, including Serene Jones and William Placher. See Serene Jones, Calvin and the Rhetoric of Piety (Louisville: Westminster John Knox, 1995); and William C. Placher, The Domestication of Transcendence: How Modern Thinking about God Went Wrong (Louisville: Westminster John Knox, 1995).
} 
of resistance from a number of historians, beginning late in Barth's life or shortly after his death. Their principal objection was that when Calvin's sixteenth-century writings were read consistently through the lens of Barth's twentieth-century theology, the result was simple distortion. Calvin's intellectual world was not the modern world. Calvin never had the benefit of reading Immanuel Kant, for example; and Kant (and, indeed, the whole progression of modern philosophical thought) was determinative for Barth's way of construing the challenges to contemporary thinking about God and humanity. In other words, many historians objected to the whole enterprise of allowing dogmatic concerns to enter into the process of historical theological interpretation. Perhaps the clearest expression of this perspective is found in Richard Muller's study of Calvin, which he has called The Unaccommodated Calvin, an effort to seek and find a historical Calvin untouched by the corrupting influence of contemporary thought. The same impulse is evident in a wide range of historians who come to different conclusions in their study of Calvin but who agree that dogmatic and historical interests should be kept separate. ${ }^{44}$

It was also among historians in the twentieth century that an important methodological shift signaled a new way of looking at the work of Calvin and his contemporaries. With the advent of social history, scholars began to shift their attention away from an earlier, almost exclusive concentration on classic theological texts, attending more closely to the lived experience of daily life through study of routine religious practices, including ritual life, contributions to social welfare, the process of discipline, and forms of mass communication. This development did more than simply enrich a biographical portrait of Calvin. In many instances, it supplied a very different lens through which to view Calvin's experience-his social, political, and ecclesial context — and the theological projects he undertook..$^{45}$

Before we turn away entirely from those who hold on to dogmatic or constructive theological interests, we ought to consider another group of scholars whose response to Barth was of rather a different order from those we have considered

\footnotetext{
${ }^{44}$ Richard A. Muller, The Unaccommodated Calvin: Studies in the Foundation of a Theological Tradition (Oxford: Oxford University Press, 2000).

${ }^{45}$ See, for example, Jeannine E. Olson, Calvin and Social Welfare: Deacons and the Bourse Française (Selinsgrove: Susquehanna University Press, 1989); Robert Kingdon, Adultery and Divorce in Calvin's Geneva (Cambridge: Harvard University Press, 1995); Karen E. Spierling, Infant Baptism in Reformation Geneva: The Shaping of a Community, 1536-1564 (Louisville: Westminster, 2009); William G. Naphy, Calvin and the Consolidation of the Genevan Reformation (Louisville: Westminster, 2003); Christopher Elwood, The Body Broken: The Calvinist Doctrine of the Eucharist and the Symbolization of Power in Sixteenth-Century France (New York: Oxford University Press, 1999).
} 
thus far. This group forms no single school, and, therefore, labeling them is somewhat awkward. In fact, one of the elements that links these theological figures is their resistance to any sort of "school mentality," a development they thought they discerned among Barth's closest disciples. Initially attracted to Barth's insights, they came to a reading significantly different from his, chiefly based on a concern that contemporary theological speaking did not banish, as definitively as Barth seemed to, the empirical approach in theology.

Several theologians could be cited here, but, for the sake of brevity, it seems wise to focus on one whose influence has been particularly formative for theological developments in late-twentieth-century America, H. Richard Niebuhr (1894-1962). Niebuhr shared Barth's interest in Calvin, and his theology consistently reflected themes basic to Reformed theological tradition-as he put it, "the sovereignty of God, the lostness of men ... and the gift of forgiveness through faith." Much of what Niebuhr produced over the course of his theological career bears the mark of his engagement with Barth and his theology. Barth's critique of the liberal drift in theology seemed to him a constructive and necessary correction, but, over time, the Barthian change in course had shown itself to be an "overcorrection." How so? Niebuhr believed that Barth and his disciples had misread and mischaracterized the tradition that set out from Schleiermacher: it "was [he said] by no means so humanistic," as they had argued. Moreover, Niebuhr was convinced that the Barthians were wrong in concentrating so intently on preserving "right doctrine." The doctrinal focus emphasized one, necessary component of the theological tradition, but Barth's circle had entirely excluded another key component: Christian experience. This imbalance threatened to impose on the theological world a new scholasticism, and it seriously diminished the richness and complexity of the historical Christian - and Reformed - theological witness. ${ }^{46}$

Niebuhr's assessment, expressed toward the end of his life (in 1960), suggested a path that would be taken by many others, including several of Barth's own students. This move would look something like a return to an empirical focus in theology. Barth's efforts to place Schleiermacher beyond the bounds of proper theology and his absolute exclusion of experience as a legitimate theological source would not seem quite as convincing in the 1960s and 1970s as they had appeared in the 1920s and 1930s. Writing in 1986, Dietrich Ritschl commented that while it might have appeared sensible to choose between Barth and Schleiermacher "in the middle third of our century, it would be foolish

${ }^{46}$ Niebuhr, "Reformation: Continuing Imperative," 142. 
to do so today." ${ }^{47}$ This attitude reflects, in part, the contributions of historical theologians such as Brian Gerrish, whose work on the connections between Calvin and Schleiermacher has gone a long way toward rehabilitating the image of the nineteenth-century theologian as a genuine successor to Calvin, rather than the Reformed apostate of Barth's representations. ${ }^{48}$

All of which is to say that the clear lines drawn by Barth in the early and middle twentieth century, the lines that divided up the theological world into neatly delineated camps, have not remained quite so clear. There is, in the air of Calvin research, much less confidence than Barth and some of Barth's early partisans had, that any single modern theologian got Calvin right or that there is one and only one legitimate contemporary appropriation of the general theological position for which Calvin argued. Where Barth's polemics were aimed at preserving the "right" reading of scripture, and perhaps incidentally a right understanding of Calvin's contribution, a greater tolerance for pluralism has come to characterize the succeeding generations of historical and theological explorers of Calvin.

If there has been a general drift away from these aspects of Barth's reading of Calvin, should we say that Barth's influence over contemporary readings of the reformer has largely dissipated? I think not. My own inclination is to say that Barth's dogmatic-theological wrestling with Calvin, as a figure who was a necessary interlocutor, was important for Calvin scholarship and remains important today - but not necessarily because of the dogmatic conclusions that Barth reached. Barth stimulated productive wresting with the Genevan reformer by showing that Calvin was worth spending time with--and not only if one agreed with him!

Here is how he put it in his parting words on Calvin in 1964: "It is not worth while really to become a 'Calvinist,' but it certainly is almost singularly worth while to become Calvin's free pupil." It will be necessary, he said, to go "beyond him in certain areas," but "one can fruitfully go beyond him only by thinking and speaking with him in the direction in which he pointed." 49 This was the procedure Barth modeled for a widening circle of scholars of

\footnotetext{
${ }^{47}$ McKim, How Karl Barth Changed My Mind, 93, 23-26.

${ }^{48}$ See especially B. A. Gerrish, The Old Protestantism and the New: Essays on the Reformation Heritage (Edinburgh: T \& T Clark, 1982); B. A. Gerrish, Tradition and the Modern World: Reformed Theology in the Nineteenth Century (Chicago: University of Chicago Press, 1978); and Dawn DeVries, Jesus Christ in the Preaching of Calvin and Schleiermacher (Louisville: Westminster John Knox, 1996).

${ }^{49}$ Barth, "Thoughts on the 400th Anniversary of Calvin's Death," 110.
} 
Calvin. In his own case, he demonstrated that differences of temperament and disagreements over key doctrinal points need not be barriers to a productive engagement with the man and his theology. This idea-that there is much to learn in Calvin and through him, much to instruct not only those who are Reformed, but also Catholic, Wesleyan, Orthodox, Muslim, Jewish, Lutheran, agnostic, and a great many more- has caught on rather well. We owe Barth a great deal for showing this to us. 


\section{Ministry in the Subjunctive Mood}

by Cynthia A. Jarvis

Reverend Cynthia A. Jarvis is a minister at the Presbyterian Church of Chestnut Hill in Philadelphia, Pennsylvania. She delivered this Women in Church and Ministry lecture in the Main Lounge of Mackay Campus Center on February 26, 2009.

E

ssayist Michelle Morano writes, "In language, as in life," moods are complicated, but at least in language there are only two. The indicative mood is for knowledge, facts, absolutes, for describing what's real or definite. The indicative helps you tell what happened or is happening or will happen in the future (when you believe you know for sure what the future will bring). The subjunctive mood, on the other hand, is uncertain. It helps you tell ... what might be.... [It] is the mood of mystery ... of faith interwoven with doubt. It's a held breath, a hand reaching out ... It's humility, deference, the opposite of hubris."1 Morano goes on to catalogue the indications of this mood, indications that are sometimes placed at the beginning of a sentence such as: I hope, or if, or as if; the subjunctive mood also follows expressions such as: It is possible, and verbs of misgiving or emotion, for example, You doubted that it could be, or you were thrilled at the possibility; it can be heard after certain indications of time, such as while, until, as soon as, before, and after, because until something has happened, you cannot be sure. The subjunctive mood also hides in good wishes: Have a good time means I am wishing for you the possibility of a good time. Finally, though not exhaustively, Morano mentions the subjunctive mood that lurks in independent clauses: This is extraordinary-isn't it?, or Suffice it to say, and rests in clauses that lace "hope with heartache. Be that as it may, for example. Or the phrase one says at parting, eyes closed as if in prayer: May all go well with you."2 I hasten to add that there are many more than two moods in language. Morano fails to mention the imperative mood of command and exhortation as well as the optative

\footnotetext{
' Michele Morano, "Grammar Lessons: The Subjunctive Mood," in The Best American Essays, Lauren Slater, ed. (Boston: Houghton Mifflin Company, 2006), 108.

${ }^{2}$ Ibid., 121.
}

DOI: $10.3754 / 1937-8386.2009 .30 .7$ 
mood of wishing that pushes the subjunctive mood to its limit, but for this night the two moods she does mention will do.

According to linguists, the subjunctive mood is more and more missed in our speech. This is no sudden happenstance. In 1901 Harper's Magazine cited a study of letters in the London Author written in June and July of 1897. Of "a few million words chosen from the works of recent authors of good repute, there were only 284 instances of the subjunctive mood and ... all but fifteen were in the verb 'to be.' ... It makes it probable," the writer goes on to opine, "that it is only a question of time how soon the subjunctive will be no longer differentiated from the indicative." ${ }^{\prime 3}$ A century later the lack of differentiation is almost complete.

The absence of the subjective mood in English may indicate nothing more than an evolution or devolution of grammar similar to the convention forbidden in my upbringing that presently permits infinitives to occasionally be split. ${ }^{4}$ But theologically I take the disappearance of the subjunctive to signal something more and turn to George Steiner's lament over the demise of the future tense for warrant. We are the only species, says Steiner, that has the means to alter our world "by resorting to 'if' clauses; who can generate sentences such as: 'If Caesar had not gone to the Capitol that day." "We can imagine the world otherwise. Whenever we begin a sentence with "if," he says, the sentence that follows "tells of a refusal of the brute inevitability, of the despotism of the fact. 'Shall,' 'will,' and 'if,' circling in intricate fields of semantic force around a hidden center or nucleus of potentiality, are the passwords to hope." ${ }^{\prime \prime}$ Steiner goes on to say that future tenses (and by implication the subjunctive mood) are "an idiom of the messianic. Take away energizing anticipation, the imperative of waiting, and these tenses will be end-stopped. 'Life expectancy' is, then, no longer a messianic ... projection, but an actuarial statistic."'

My thesis is that women may be more likely to do their believing, their preaching, and their ministry in the subjunctive mood, a mood that would seem to correspond to the kind of truth both revealed and hidden in the incarnation, a mood

\footnotetext{
${ }^{3}$ Harper's Monthly Magazine, volume CII, December 1900 to May 1901 (New York: Harper and Brothers, 1901), 433.

${ }^{4}$ Parenthetically I was drawn to the Op Ed in Tuesday's New York Times (February 24, 2009) by Patricia T. O' Conner and Stewart Kellerman concerning the president's use of "I" when he properly should say "me." Apparently it was not until the mid-1800s that "I" ceased to be an object of a verb.

${ }^{5}$ George Steiner, Grammars of Creation (London: Faber and Faber, 2001), 5.

${ }^{6}$ Ibid.

${ }^{7}$ Ibid., 8.
} 
that refuses brute inevitability and the despotism of the fact. Note that the thesis itself may be uttered only in the subjunctive mood, as I cannot be certain about it. I have known men whose ministry has majored in the subjunctive mood, so I am only supposing women may be more likely —as are many of the sentences in the manuscripts of women in the pulpit, as are the assurances of women in the intensive care unit, as are the statements of women in the classroom of the church - to do ministry in the subjunctive mood, the mood of mystery where faith is interwoven with doubt, when a held breath or a hand reaching out is about all one can honestly manage.

Now if you are listening to these words as one whose speech tends toward the indicative mood, you may already be thinking that the subjunctive mood betrays a lack of faith, whereas the indicative mood indicates rock solid orthodoxy. Suffice it to say, I hope by the end of this hour you might be persuaded to think again! Facts and absolutes are statements that presume no leap on the part of a speaker who already inhabits a certain universe. To coin Karl Barth's phrase about religion, facts and absolutes are what people believe in instead of God.

Or to put it another way and in the words of Lesslie Newbigin, "To believe that the crucified Jesus rose from the dead, left an empty tomb, and regrouped his scattered disciples for their world mission can only be the result of a very radical change of mind. Without that change of mind, the story is too implausible to be regarded as part of real history. Indeed, the simple truth is that the Resurrection cannot be accommodated in any way of understanding the world except one of which it is the starting point." 8 Were the church's proclamation to claim anything less, we would be left with nothing real about which to be amazed. Still, the Resurrection is "a fact of a different kind," to quote Newbigin again. So on Easter morning the church shouts "Christ is risen!" in the indicative mood, knowing that the kind of fact it is can only be heard to be true as it transfigures human objectivity itself. Short of such a change of mind, the indicative mood indicates that a person has arrived ... presently, though not proleptically ... in the camp of the assuredly saved, whereas ministry in the subjunctive mood has to do with faith and hope and the kenotic work of love that is the incarnation.

To consider this thesis, we turn not to statistics that may have been gathered by social scientists-word studies of sermons, for instance, that one can stumble upon in the crack cocaine stupor that Googling sometimes induces ... studies that

\footnotetext{
${ }^{8}$ Lesslie Newbigin, Truth to Tell: The Gospel as Public Truth (Grand Rapids: Eerdmans, 1991), $10-11$.

${ }^{9}$ Ibid., 10.
} 
may note the number of times a sentence in the subjunctive mood appears in a sermon preached by a woman compared with the indicative or even imperative sentences proclaimed by a man. That is the stuff of D.Min. theses. Tonight we will turn not to statistics but to scripture and to three women who have led me to this surmise.

We begin with the conversation between an as yet unnamed woman and the serpent in Genesis who engages the woman "by voicing the woman's doubt," writes Phyllis Bird, "and her attempt to discern the rationale for the prohibition"10: "Did God say, "You shall not eat from any tree in the garden?"” The mood implied in the question is subjunctive: I doubt that God said you shall not eat ... don't you? According to the text, the man alone has heard God's address directly. Of course! God has said to the man, "Of the tree of knowledge of good and evil you shall not eat, for in the day you eat of it, you shall die." An imperative followed by an indicative. This is God speaking, after all. What the man said to the woman in this regard we do not know. We only know that what the man said made quite an impression. The woman restates and overstates the prohibition to the serpent: "You shall not eat ... you shall not touch ... or you shall die." In response and in the indicative mood, the serpent states a fact, an absolute: "You will not die. You will be like God, knowing good and evil."

Curiously, with this fact before her, for a split second, the woman sees the world not through the eyes of prohibition but possibility: sees that the tree was good for food ... was a delight to the eye ... was to be desired." It is as though (subjunctive mood!), holding our breath before she takes a bite, we see her not in the garden of our fall but in the garden of which the Lord God said in the first of Genesis, "See, I have given you every plant yielding seed that is upon the face of all the earth; ... you shall have them [all] for food ... And it was so. [Period!] God saw everything that [God] had made ... indeed ... was very good." That was that: a sixth day over, a seventh to rest. So goes the first story.

I wonder as I hold my breath: What if the woman had been written into the first story of creation? No doubt the plot would never have thickened. The story of our salvation would not have been set in motion. Be assured that I do not mean to present this as though it were a divine option at the beginning. To cite Robert

\footnotetext{
${ }^{10}$ Phyllis A. Bird, Missing Persons and Mistaken Identities: Women and Gender in Ancient Israel (Minneapolis: Fortress, 1997), 189.
} 
Jenson citing Martin Luther's "manual for parents and church-school teachers, 'God has created us precisely to redeem us." "'11 Still, in that split second that never existed before the woman chooses to know good and evil rather than God, I imagine the woman to be the precursor of our gratitude, of our giddiness, of our glory in the garden where nothing, at first, is believed to be off-limits, where all things would seem to be available for our enjoyment, even God! As faith is delight and gratitude and astonishment in the midst of God's good creation, she is the mother of the faith, the radical curiosity, the utter amazement that leads us to exclaim, "This is extraordinary-isn't it!"

But then she swallows and delight is turned to dread, curiosity gives way to murderous shame, theological wonder at God's address is transformed into the unquestioning reception of inerrant information. The Fall is a fall into the indicative mood and into the world we choose to know through the determined lens of good and evil. On the basis of the serpent's unqualified assurance and from that mythic moment on, I would venture to say that religion has been too much in the business of certitude, the sentences of the saved awash in the indicative mood, the tomes of second-rate theologians made thick with imperative pronouncements concerning the absolute who appears to be more a principle than a person.

I think you and I fall into absolutism because the only true knowledge our knowledge of good and evil has netted is knowledge of our nakedness. Given the fact that we have not died literally (here "the snake appears to be right," 12 says Bird), we know we are about to die a thousand deaths if we do not do something to cover up our "weak, exposed and vulnerable" situation. One antidote to vulnerability is speech in the indicative mood (bested only by speech in the imperative mood). "Instead of knowing only God who is good ..." writes Dietrich Bonhoeffer at the beginning of Ethics, "and instead of knowing all things in [God], [we] know [ourselves] as the origin of good and evil. ... Bearing within [ourselves] the knowledge of good and evil, [we have] become judge over God and [mortals]."13

That is to say, human judgment born of knowing good and evil imposes upon speech both an indicative and an imperative mood. When Bonhoeffer instead considers what it means to know God's will rather than good and evil, he speaks of God's will first in the subjunctive mood: "The will of God may lie very

${ }^{11}$ Christopher R. Seitz, Nicene Christianity: The Future for a New Ecumenism, "For Us ... He Was Made Man," Robert W. Jenson (Grand Rapids: Brazos, 2001), 76.

${ }^{12}$ Bird, Missing Persons and Mistaken Identities, 189.

${ }^{13}$ Dietrich Bonhoeffer, Ethics (New York: Simon \& Schuster, 1995), 23. 
deeply concealed beneath a great number of possibilities. The will of God is not a system of rules which is established at the outset ... [and] ... is no longer a matter of a [person's] own knowledge of good and evil, but solely of the living will of God. ... It depends solely upon the grace of God, and this grace is and requires to be new every morning." 14

Bonhoeffer's own life and death suggest that very deeply concealed beneath a world of facts and absolutes, and finally revealed in the flesh and blood of a human life, there is another way of inhabiting this time and space east of Eden. It is a way of being in the world marked by a vulnerability that is the opposite of hubris, vulnerability often indicated in speech by the subjunctive mood. Paul Lehmann in The Decalogue and a Human Future cites Italian novelist Niccolo Tucci in this regard who speaks of "the willful acquisition of vulnerability," which, according to Lehmann, "underlies the priority of weakness over strength, of humility over pride in the possession of capacities, opportunities, achievements, according to "nature's lottery." 15 I think it is just this vulnerability that author Barbara Grizzuti Harrison has in mind as she offers her own subjunctive spin on the consequences of the Fall: "Eve gave us the world as we know the world," she writes, "beautiful, flawed, dangerous, full of being. She gave us smallpox and Somalia, polio vaccine and wheat and Windsor roses. ... She (not Mary) is the mother of my children, born in travail to a world of suffering their presence may refresh." 16 To wit: What if this child in my arms were one day to broker peace in the Middle East or discover a cure for AIDS or put an end to hunger? Every use of an "if" sentence tells of a refusal of the brute inevitability, of the despotism of the fact!

Harrison goes on to suggest a far more significant consequence of the Fall for the faith we have been set apart to proclaim. "Even the alienation from God we feel as a direct consequence of her Fall makes us beholden to her: the intense desire for God never satisfied, arises from our separation from God."17 The woman is finally the handmaid not of our mastering of divinity or of our quest for absolute certainty but of our subjunctive human cries in the dark for a hand greater than our own to hold us in being. She is handmaid of our doubts, our longings, our sighs too deep for words. She insinuates upon our fearful mortality the distance absolutely necessary if we are to be children not of some mindless

\footnotetext{
${ }^{14}$ Ibid., 41.

${ }^{15}$ Paul Lehmann, The Decalogue and a Human Future (Grand Rapids: Eerdmans, 1995), 35.

${ }^{16}$ Christina Buchmann and Celina Spiegel, Out of the Garden: Women Writers on the Bible (New York: Fawcett Columbine, 1994), 1.

${ }^{17}$ Ibid.
} 
religious coercion but of the God who in freedom, once for all, quit the distance we keep - the same God who, all the while, fiercely guards our freedom to cut and run.

I think, in the first place, this is why women may be more likely to do ministry in the subjunctive mood. We inhabit the land east of Eden as those who have never been strangers to the willful acquisition of vulnerability. I do not rail against this now as some once did when there seemed to be little that was willful about our cultural vulnerability. Speaking personally, even from the time when there were only a handful of us-mounting the pulpit or peering around the corner of a hospital room or feeling our knees shake as we presumed to teach a classroom of peers what we barely understood ourselves-from that time until now I have taken the distance I live from certainty to be a gift of God for the sake of the gospel I have been ordained to proclaim. The longing, the doubt, the sighs too deep for words find me climbing the steps to the pulpit with an urgency and an astonishment that are missed in others whose proclamations major in the indicative. Such proclamation sends to my study the lost who have an inkling that they are not too far gone if even their minister admits to whistling in the dark now and again. In the give and take of the classroom, the honesty dared in talking about the efficacy of prayer or the agency of God in history or the wild promise of eternal life or the sort of truth the Bible tells becomes a conversation whose goal is not an answer but our collective sighs too deep for words made audible. Make no mistake, I am a relentless student of the history of doctrine; I thrill at explicating the labyrinthine theological battles that have led us to confess God in three-personed names. The substance of the church's faith is the air I breathe. But the distance I live experientially from the God the church confesses leaves me astonished, agog, incredulous, and overwhelmed that this could be so. I am beholden to Eve, in the first place, for the freedom fraught with human frailty and vulnerability that marks the faith I have been given to proclaim.

"Without Eve," Harrison concludes in this interlude before we turn to consider the second woman who has led me to this surmise, "Mary would not be our sister." ${ }^{" 18}$ Much, of course, has been made of this from the second century on. In Reforming Mary, Beth Kreitzer notes that Justin Martyr "contrasted the virginity and obedience of Mary with the virginity and disobedience of Eve." Irenaeus said the same, making Eve "the cause of death for herself and the whole human

${ }^{18}$ Ibid., 2. 
race," while Mary became "the cause of salvation both for herself and the whole human race."19

In the fifteenth century, Fra Angelico's many paintings of the Annunciation locate a garden to the left of the cloister where Mary sits as she receives God's Word. The garden in the Annunciation that adorns the north corridor of the Dominican Cloister of San Marco in Florence is flecked with what look like little red flowers. On closer inspection, the brush strokes and paint are identical to the brushstrokes and paint of Christ's blood dripping from the ubiquitous crucifixes that adorn the cells of novices at San Marco. The garden is the garden of our fall, from which Mary's Son will redeem us. In the medieval period, again according Kreitzer, Amadeus of Lausanne went so far as to borrow the Pauline phrase concerning Adam and Christ, claiming that "as in Eve all die, so also in Mary all shall be made alive." 20 I do not intend to go that far! Yet as I have paid attention to the mood of the conversation between the woman and the serpent in contrast to the mood of the conversation between Gabriel and Mary, I do find myself entertaining the possibility that the indicative mood into which Eve fell-and much of religion with her-is countered, to say the least, by the subjunctive mood imagined in the moment before the Fall and manifest in Mary's response to the Annunciation.

So we turn to Mary. Contrary to Lorenzo Lotto's Annunciation, Mary does not cut and run. Rather, to the angelic messenger's announcement that she will conceive and bear and name a son who will be called Son of God, Mary responds, "How can this be ... ?" Here I want to suggest two things: first, that the truth revealed in the incarnation, God's Word become flesh, resists the indicative mood of religious certitude; and second, that the subjunctive mood is the mood that indicates a merely human being has heard God's address.

Concerning the resistance of God's Word to the indicative mood, suffice it to say that when the statement "God was in Christ" is said with certitude but without the change of mind Newbigin spoke about, the claim becomes a fact alongside every other fact. Admittedly, its utterance may elicit, from the one who hears, the identical words Mary has said to the angel: "How can this be?" Yet the mood of this question asked of a fact we can know in the same way we know other

${ }^{19}$ Beth Kreitzer, Reforming Mary (Oxford: Oxford University Press, 2004), 36.

${ }^{20}$ Ibid. 
facts presumes that the competence of our knowing is at stake. Theological claims made in the indicative mood often presume just this. They may properly echo the words of the church's confession. Still, they have little if anything to do with the God who was incarnate in Jesus of Nazareth because they are put forth as facts we should be able to grasp. The Word that is God's Word resists such knowing.

Consider the same words spoken by one whose speech, in response to what has been heard, is encompassed by a "mood of mystery ... of faith interwoven with doubt ... of a breath held, a hand reaching out ... of humility and deference.".21 The trustworthiness of God is alone at stake in what is claimed. The truth insinuates itself upon our lives not by way of disembodied propositions but through the Word of God incarnate in a human life. When, in response, we attempt to say what "God was in Christ" means-to speak theologically-then every step we dare to take toward faith is prefaced by a subjunctive exclamation: "This is astounding ... isn't it!"

A quite specific astonishment stands at the beginning of every theological perception, inquiry and thought, in fact at the root of every theological word, said Barth in a lecture on Wonder. This astonishment is indispensable if theology is to exist and be perpetually renewed as a modest, free, critical, and happy science. If such astonishment is lacking, the whole enterprise of even the best theologian would canker at the roots. On the other hand, as long as even a poor theologian is capable of astonishment, he is not lost to the fulfillment of his task. [She] remains serviceable as long as the possibility is let open that astonishment may seize [her] like an armed [bandit].22

So rather than the indicative mood of religious certitude, the language we may borrow to speak of the God who was in Christ is something akin to the language of the heavenly host that roused the shepherds abiding on the hills and sent them run, run, running to Bethlehem.

Then in the second place, Mary's "How can this be?" leads me to suggest that the subjunctive mood is the mood that indicates a merely human being may possibly have heard God's address. I think it not by chance that the upright and good Zechariah, the man who has known good and evil according to the law, asks Gabriel, "How will I know that this is so?" Coming immediately before the announcement of Christ's conception, this is a story of fallen human knowledge

\footnotetext{
${ }^{21}$ Morano, 108.

${ }^{22}$ Karl Barth, Evangelical Theology: An Introduction (Grand Rapids: Eerdmans, 1963), 64.
} 
still seeking divine warrant to speak of God in the indicative mood, to speak as a creature who knows for sure because God has spoken more or less directly. We read that such speech is silenced though not yet redeemed by Gabriel; rather Zechariah's voice is restored in order to lend authority to the name Elizabeth has already given their child.

But to the indicative mood of the angel who announces, "You will conceive and bear and name," Mary asks a question whose words, as we have just noted, brim with astonishment: "How can this be? She cannot conceivably fit what she has heard into merely human ways of knowing, of knowing something for a fact or knowing something is so. In his commentary on Mary's question to the angel, Calvin holds that she has taken "what is beyond the common order of nature ... to be impossible. She reasons I know not a man: how then can I believe that what you tell me will happen?" Yet he acquits her of her failure to immediately rise "by faith to the boundless power of God" and goes on to note that "she does not hesitate or inquire in such a manner as to lower the power of God to her senses; but is only carried away by a sudden impulse of astonishment to put this question." ${ }^{23}$ Likewise, Luther in his sermon on the same text observes that the address of the angel sent "a shot of unbelief in her heart" 24 and "took her breath away with shock."25

The subjunctive mood is the mood that indicates a human being has heard the address of God and has heard the address of God. In IV.2 of Church Dogmatics, Barth says that revelation makes a place for itself in human cognition. "It does not allow itself to be halted by the normal and customary limitation and contingency of [our] ability to know.... It gives itself to be known. It creates the possibility of a seeing and hearing and understanding of it. Or rather, it creates eyes to see it and ears to hear it and a mind to understand it." ${ }^{.26}$ It is as though Mary's "How can this be?" invites us to imagine God in the act of making a place in Mary's cognition rather than Mary's cognition making a place for God. Now in the spirit of full disclosure, I am well aware that one can light down about anywhere in the Dogmatics and find a sentence or two to make your point. So I admit that Barth does go on to say that once revelation is known, it "makes itself known as a fact. It opens, as it were, the barrier or door of its objectivity."27 Yet I think the dialectic has another bounce to it: you still must say that it is a fact we

\footnotetext{
${ }^{23}$ John Calvin, Commentaries on the Harmonizing of the Evangelists Matthew: Mark and Luke Part 1, Edinburgh Translation Society, 1847-50.

${ }^{24}$ Kreitzer, 30.

${ }^{25}$ Martin Luther, "Sermon on the Day of the Annunciation" 1532, WA LII, 632-33.

${ }^{26}$ Karl Barth, Church Dogmatics IV.2 (Edinburgh: T\&T Clark, 1958), 120.

${ }^{27}$ Ibid.
} 
cannot grasp, an objective reality we cannot hold. I think we must say that this place made in our minds by revelation is not a place made once for all or once forever in the course of a human life. It is new every morning, something that Barth goes on to say himself:

We should be fools-real fools in the biblical sense of the word-if either to ourselves or others we pretended to be the expert bearers of revelation, appealing for our authorization (in our own eyes and those of others) to a knowledge of revelation which is either transmitted to us institutionally or infused personally.... We can and must act as those who know. But we must not claim to be those who know. For if our knowledge of this fact from its self-revelation is not new every morning, if it is not newly received ... with empty hands, as a new gift, it is not this knowledge at all. ${ }^{28}$

When I reflect on almost thirty-five years of ministry, I hear myself as I prepare to teach and preach, as I enter a hospital room or stand at the edge of an open grave, as I dip my hand in the waters of baptism or rip the half-cut loaf in two before the people I have been given to love and serve, I hear myself saying with Mary, "How can this be?" How can it be that God was in Christ? And for most of these years I have ended the day with a prayer akin to the prayer etched on my heart and repeated in many a sermon or lecture by the priest in Georges Bernanos's Diary of a Country Priest, "Oh miracle, thus to be able to give what we ourselves do not possess - sweet miracle of our empty hands! ... Lord, I was stripped bare of all things as you alone can strip us bare, whose fearful care nothing escapes nor your terrible love!" Therefore, it is to our empty hands I finally turn tonight and so to Mary Magdalene at the tomb of Jesus in John's gospel.

\section{IV}

"Early on the first day of the week, when it was still dark," wrote John with words that mean to return us, I think, to the word with which John began his gospel: to the beginning of God's Word before time and space, to the light that had come into the world in the fullness of time that now had apparently been overcome by those who preferred the darkness. When it was still dark, says John, Mary Magdalene came to the tomb.

\footnotetext{
${ }^{28}$ Ibid., 124.
} 
We begin this time in familiar territory. Mary's grief does not escape our Newtonian ways of knowing the facts: where time is allotted; the present, fleeting; the past, irretrievably lost; the future, fated by death. Newton's mechanics were the earliest modern bet human beings made about the facts and so the nature of time and space. This bet holds that "the universe is equipped with a kind of built-in clock that ticks off seconds identically, regardless of location or epoch." But the cost of adhering to Newton's description of time is high, writes Brian Greene, for "our willingness to place unjustified faith in immediate perception or received wisdom leads us to an inaccurate and starkly limited vision of reality" (to an acceptance of brute inevitability and the despotism of the fact). ${ }^{29}$

Yet within the confines of Newton's mechanics, we can imagine how it was, why it was that Mary Magdalene rose before dawn on the first day of the week. Most of us have done the same. Mary had come to the tomb while it was still dark to grasp the fact of Jesus's death, a fact that existed for Mary like the kitchen table because she scrubbed it. The facts she perceived were these: the stone is inexplicably rolled away, the tomb is inconceivably empty, the grave clothes, immaculately folded. While it was still dark, however, a truth from outside her understanding was about to insist she account for its reality.

John claims immediately that the Beloved Disciple saw the empty tomb and believed, though the next sentence admits neither he nor Peter had any inkling as to the substance of their belief, "for as yet they did not understand the scripture, that he must rise from the dead." Therefore, Peter and the Beloved Disciple simply turn toward home with the facts. Again the empty tomb is a fact; the risen Lord is quite another matter!

Mary Magdalene did not run but instead stood weeping outside the tomb. No doubt she remained in the grief that, for a stage or two, refuses the brute inevitability, the despotism of the fact. But it seems to me her refusal to run as Mary had refused to run also partakes of the willful acquisition of vulnerability-a will not first her own but the will of God's revelation making a place in her cognition. Mary has remained because the brute inevitability, the despotism of the fact of death cannot account for her experience of Jesus. Refusing to accept the evidence of her immediate perception, she enters the empty tomb in utter vulnerability.

There she encounters two angels seated one at the head and the other at the foot of an empty grave slab. The detail of empty space is not an idle detail, according

${ }^{29}$ Brian Greene, "The Time We Thought We Knew," New York Times, January 1, 2004. 
to the Archbishop of Canterbury Rowan Williams, but is meant to recall the ark of God flanked by two cherubim. "Enshrined or carried into battle, the ark ... marked the presence of God with an empty space-the space between the cherubim": the presence of an always invisible God who could not be possessed or contained or held, but "who is where [God] is not."

"Why are you weeping?" the angels ask Mary incredulously from the realm of God. From out of Newton's time and space Mary answers, "They have taken away my Lord, and I do not know where they have laid him." Then, as though the hand that had rolled away the stone and arranged the burial linens had hold of her, too, Mary turns toward the realm devoid of time and space where her Lord has gone and out of which he now appears. At first, she mistakes Jesus for a gardener tending the redemptive garden John has traced over the garden of our fall.

But then, in a moment of astounding tenderness, the risen Lord simply speaks her name, "Mary," and she turns again saying, "Rabbouni." The leap is quantum, and the mood, though lacking a supporting sentence, is surely subjunctive: the mood of mystery ... of faith interwoven with doubt ... a held breath, a hand reaching out. Mary's temptation and ours in this barely liminal encounter is to hold him, to return him to the space and time of Euclid's geometry and Newton's mechanics where God exists because, short of the leap faith is, we want to be certain the resurrection is true. In response to our desire to hold him, however, another empty space becomes evident.

The fresco of Fra Angelico that drew me to spend my sabbatical in the Dominican Cloisters of San Marco in Florence was the fresco known as "Noli Me Tangere," or "Do Not Hold Me." I imagine Fra Angelico has painted the moment just after the moment in which Mary Magdalene exclaims, "Rabbouni." My eye goes to the empty space between two hands whose movement is both toward and away. The distance is the center of this fresco. Like Jesus's feet-one turned to go and the other planted in the garden grass next to Mary-his hands reveal the paradox of reaching out and holding apart. Mary is all movement toward him and yet obediently stops short of acting on her longing.

I was drawn to this fresco and so drawn for a season to the Cloisters of San Marco because this is the liminal encounter and this is the distance kept by those who do ministry in the subjunctive mood. I do not doubt revelation has made a place not only in my cognition but in my life for the risen Lord. Yet as I rise on Easter morning (the morning that most terrified me when I woke up no longer

${ }^{30}$ Peter Steinfels, "Beliefs," New York Times, April 19, 2003. 
an associate minister scheduled to preach on the Sunday after Easter), I rise to face a crowd asking of a fact, "How can this be?"' I ask the same question ... with astonishment ... and sometimes we meet in the center of the fresco that is the emptiness of life without God in the world. From that space I continue and speak with the willfully acquired vulnerability known to those who have been set apart to account for a truth that has come to us all from outside our understanding. I have risen while it was still dark on Easter morning, humbled and terrified to be the one privileged to proclaim the most astounding Word a human being has ever uttered: He is risen! I can always cut and run ... but I will not and no longer wish to. For though ministry in the subjunctive mood takes its toll on those laboring in the bounds of an institution hell bent on certainty, this is the adventure that has been worth my life.

These days, the days of my sixtieth year of life and my thirty-fifth year of ordination, I think of Mary Magdalene not in pastels but as Donatello would later sculpt her out of wood in old age-broken, toothless, wandering the streets of Florence at night, her life marked by the emptiness of the space where God is not, some would say. But look again, for in her I see a sister who has known too well the distance at the center of the fresco that is our lives lived East of Eden, yet who also knows her living Lord whom she cannot hold. She wanders the streets of Florence by night awash in the mood of mystery ... of faith interwoven with doubt ... of a held breath, a hand reaching out. And so I imagine her exclaiming if she should meet again the One who has redeemed her vulnerability by his own, "It is extraordinary—isn't it?" Thanks be to God! 


\section{The Theology of Providence}

by David Fergusson

David Fergusson is professor of divinity and principal of New College, the School of Divinity, at the University of Edinburgh. This article represents an overview of the Warfield Lectures, which Dr. Fergusson delivered on campus from February 16 through February 19, 2009.

\section{$T$} he subject of providence is one that cuts across several traditional disciplinary boundaries. These include philosophical, systematic, and pastoral theology. In dealing with the form, content, and purpose of the divine rule over the world, providence touches upon speculative and dogmatic themes that are also of deep existential significance. There are at least four reasons for tackling this subject in our current context. First, it is a central article of Christian faith. If the doctrines of creation and redemption are to be properly related, then there must be some account of how the work of the Creator is extended beyond an initial act of making the universe from out of nothing. Second, the problem of evil calls into question the divine ordering of the world and thus demands an account of providence that offers resources for understanding both the divine rule and the manifest opposition to it. And, third, the ways in which the concept of providence is expropriated by civil religion, political rhetoric, and varieties of cultural superstition require a theological account that is distinctive and alert to the possible abuses of this topic. Fourth, the doctrine continues of course to be of pastoral significance for Christian faith and thus requires some responsible theological comment.

A classical Reformed text, the Heidelberg Catechism (1563) articulates elegantly both the dogmatic and pastoral content of the doctrine of providence. As the Father Almighty, God not only rules over all things but also ensures that these serve a purpose for which we can be thankful and cheerful. 


\section{Q. What do you understand by the providence of God?}

A. The almighty and ever-present power of God whereby he still upholds, as it were by his own hand, heaven and earth together with all creatures, and rules in such a way that leaves and grass, rain and drought, fruitful and unfruitful years, food and drink, health and sickness, riches and poverty, and everything else, come to us not by chance but by his fatherly hand.

\section{Q. What advantage comes from acknowledging God's creation and providence?}

A. We learn that we are to be patient in adversity, grateful in the midst of blessing, and to trust our faithful God and Father for the future, assured that no creature shall separate us from his love, since all creatures are so completely in his hand that without his will they cannot even move. ${ }^{1}$

In what follows, I offer several theses. They aim to mark out an account of providence that is more intellectually modest and low-key than classical formulations but one which also seeks to be adequate to scripture and the pastoral needs of the Church.

1. The classical doctrine of providence as it emerged in the history of the Church is too heavily indebted to philosophical resources in the ancient world, particularly Stoicism.

The term providence itself is not widely used in scripture. Reference is made to the Latin providebit in Genesis 22:8, where Abraham tells Isaac that God will provide a sacrificial lamb. Yet generally the term providentia and the Greek pronoia are taken to denote divine foresight. Although these are closely linked to notions of provision, rule, guidance, and purpose, the term providence seldom occurs in either the Hebrew Bible or the New Testament.

Its linguistic prominence in Christian theology is more indebted to the influence of ancient philosophy. This has also had a significant effect upon its material content. Here an account of providence was offered, largely in conscious opposition to Epicurean notions of chance. In Plato's Laws, divine rule is affirmed against the view that the gods have no interest in human affairs. For the Epicureans, however, natural and historical events are not governed by any laws or purpose. These happen in a haphazard manner that is attributable only to chance. In face of this, Stoic philosophy insists upon the determination of everything by the operation of natural laws. These laws reflect a divine logos

\footnotetext{
${ }^{1}$ Heidelberg Catechism, Questions 27 and 28, in Reformed Confessions of the Sixteenth Century, Arthur C. Cochrane, ed. (London: SCM, 1966), 309-10.
} 
that infuses the cosmos and works inexorably to fulfill a more natural purpose. Consider the following remarks of Seneca.

This much I now say, that those things which you call hardships, which you call adversities and accursed are, in the first place, for the good of the persons themselves to whom they come; in the second place, that they are for the good of the whole human family, for which the gods have a greater concern than for single persons; again, I say that good men are willing that these things should happen and, if they are unwilling, that these things happen thus by destiny, and that they rightly befall good men by the same law which makes them good. ${ }^{2}$

Two features of this account are relevant in assessing its appropriation by Christian theology. First, it is an austere account in which an impersonal moral purpose is fulfilled through everything that happens. Its tone is reminiscent of sermons that many of us will have heard. Within this worldview the sufferings that befall us are to be accepted as our fate, which if we willingly assent to it in the proper manner, will lead to an increase in virtue. Second, this account tends toward a radical determinism in the role that is assigned to human freedom and responsibility. Both Zeno and Chrysippus liken the human situation to that of a dog tied to a cart. The dog can willingly run along keeping pace with the cart, or else it will be dragged. Either way, its destination remains the same. ${ }^{3}$ On this account every event thus serves a purpose. Foreseen by the gods, the total system of causes governing the universe can be described as "fate."

These tendencies are undoubtedly present in the writers of the early church, but they are also adapted and at times checked and corrected. In her valuable study of the literature, Silke-Petra Bergjan notes the recurrence of several themes: the retributive character of divine providence, its pedagogical function, its eschatological ordering, and its particular concern for individuals. ${ }^{4}$ Although much of the thought and language is borrowed, it reflects an attention to scriptural themes. For example, Theophilus of Antioch can write as if pagan and Christian teachers say much the same thing. "The Sibyl, then, and the other prophets, yea, and the poets and philosophers, have clearly taught both concerning righteousness and judgment, and punishment; and also concerning providence, that God cares for us, not only for the living among us, but also for those that are dead."

\footnotetext{
${ }^{2}$ Seneca, "De Providentia," in Moral Writings, Loeb Classical Library, John Basore, ed. (London: Heinemann, 1928) III.1-2, 15.

${ }^{3}$ See John Rist, Stoic Philosophy (Cambridge: Cambridge University Press, 1969), 127.

${ }^{4}$ Silke-Petra Bergjan, Der Fürsorgende Gott (Berlin: De Gruyter, 2002).

${ }^{5}$ To Autolycus, Book Two, 38 .
} 
On the other hand, the scriptures provide clearer and deeper insights into the workings of God's providence. Justin Martyr sees not a fatal necessity or an impersonal fate governing the affairs of human beings but a God with foreknowledge, oversight, and provision for individual men and women. ${ }^{6}$ Clement of Alexandria seems to split the difference by arguing at some length that providence is a widely accepted and ineluctable truth throughout the nations of the world, but that its finer details are understood only by Christian philosophers. God is understood as the "invisible and sole, and most powerful, and most skilful and supreme cause of all things most beautiful," but the inference of these truths require the teaching of the church. ${ }^{7}$

Two later examples, both from the early fifth century, illustrate further some of the tensions already latent within second-century teaching on providence. Theodoret of Cyrus, in a treatise dedicated to the subject, advances a series of rather engaging apologetic arguments for providential order. In many ways, these anticipate the design arguments of Archdeacon William Paley by the best part of 1500 years. The providence of God is apparent in the regulation of the planetary system, the seasons of the year, the harmony between species and environment, and the physiognomy of the human body. Even our buttocks are happily arranged, he argues, to provide a natural couch for sitting on the ground or on stone. ${ }^{8}$

Written around the same time, Augustine's City of God offers a more somber and chastened reflection on the ways of providence but nevertheless one that also affirms the rule of God throughout the cosmos. In the City of God, he inveighs against all forms of astrological fatalism. The constellation of the stars has no causal influence upon life on earth. These are not determined by remote events. As in Theodoret, much of the discussion has a curiously modern ring, particularly in his extended discussion of twins. Their similarities and differences must be accounted for by proximate causes of parentage, diet, upbringing, external circumstances, and so on. None of these can be explained by the identical constellations at the time of their birth. And yet we can also affirm that God through these secondary causes, including voluntary agents, brings about an

\footnotetext{
${ }^{6}$ For example, Justin Martyr, First Apology, 44.

${ }^{7}$ Clement, Stromateis, 5.14. See also Origen's Stoic-like description of providence. De Principiis, Book 2.1.3. "Although the whole world is arranged into office or different kinds, its condition, nevertheless, is not to be supposed as one of internal discrepancies and discordances; but as our one body is provided with many members, and is held together by one soul, so I am of the opinion that the whole world also ought to be regarded as some huge and immense animal, which is kept together by the power and reason of God as by one soul."

${ }^{8}$ Theodoret of Cyrus, On Divine Providence, trans. Thomas Halton (New York: Newman, 1988), Discourse 3.21.
} 
overarching purpose. The political significance of this will be mentioned in the fourth lecture.

We might draw two lessons from all this. The assumption that church shared providentialist beliefs with the philosophies of the ancient world led its teaching in one direction. No doubt the struggle against theories of chance and fortune helped to forge this alliance. But it led to an overbearing determinism that leaned too far toward an acquiescence with the way things were. This ignored more biblical themes of struggle and resistance, these requiring a more dynamic approach to the subject, with reference to the agency of the Holy Spirit. On the other hand, it is clear that already in the early church the attention to scripture required some criticism and qualification of regnant theories of providence. Divine providence is purposive, particular, and parental and not to be confused with fate or fortune.

The leaning in a Stoic and determinist direction generated some serious problems for the later articulation of the doctrine, at least in the Latin West. In Thomas Aquinas and John Calvin, for example, we find much that reflects the Stoic inheritance. ${ }^{9}$ The primal will of God explains everything that happensnothing that is not fixed by divine decree can occur in the cosmos. While God's will is mediated by secondary causes, the latter are instruments that in every respect fulfill the former. One consequence of this is that the distinction between divine permitting and willing, more characteristic of Orthodox theology, tends to collapse in much medieval and Reformed dogmatics. ${ }^{10}$ In practical terms, it leads to an account of providence in which too much is attributed to a positive divine will, at the expense of rendering God inscrutable and impersonal. This exercised a powerful hold over the Western tradition and became a source of complaint by Karl Barth in its radical revision of the Reformed doctrine of providence. ${ }^{11}$

\section{The doctrine of providence is misplaced when presented on speculative,} introspective, or political grounds. Grounded in revelation, it is an article of faith that needs to be carefully distinguished from surrogate accounts.

\footnotetext{
${ }^{9}$ See, for example, Summa Theologiae 1a.22.1 and Institutes I.17.8. I have tried elsewhere to show how these determinist accounts are somewhat modified by the presence of scriptural themes in Aquinas and Calvin. See "Divine Providence and Action," God's Life in Trinity, Michael Welker and Miroslav Volf, eds. (Minneapolis: Fortress, 2006), 153-65.

${ }^{10}$ See David Bentley Hart, "Providence and Causality: On Divine Innocence," in The Providence of God, Francesca Murphy and Philip Ziegler, eds. (London: T\&T Clark, 2009), 34-56. ${ }^{11}$ For a summation of the doctrine in providence in Reformed orthodoxy, see Heinrich Heppe, Reformed Dogmatics (Grand Rapids: Baker, 1978), 251-80.
} 
We cannot assume the divine rule of the world on the basis of empirical observation. Too much that happens is unpredictable and contrary to what we understand to be the will of God for this to be attributed to providence. Theologians, preachers, and pastors of course have attempted this, sometimes in ways that were well-intentioned and even on occasion inspiring. Consider this extract from a sermon of Hugh Blair, the great preacher of the Scottish Enlightenment.

Why this man was prematurely carried away from the world in the beginning of a promising course; why that deserving family were left overwhelmed with grief and despair, by the loss of one who was their sole benefactor and support; why friendships cemented by tender ties were suddenly torn asunder by death; these are inquiries to which we can now make no reply, and which throw a dark gloom over the conduct of the Almighty. But the spirits of the just above, who are admitted to a larger view of the ways of God, see the reasons of such counsels. They see that one man was seasonably taken away from dangers and evils to come, which, unknown to him, were hovering over his head. They see that Providence was in secret preparing unexpected blessings for the family who appeared to be left disconsolate and hopeless. They see that it was time for friendships to be dissolved, when their longer continuance would, to some of the parties, have proved a snare. Where we behold nothing but the rod of power stretched forth, they discern an interposition of the hand of mercy. Let us wait till this promised hereafter arrive, and we shall in like manner be satisfied concerning the events that now disturb and perplex us. ${ }^{12}$

Although this is moving and appealing in many ways, it suggests too hastily that everything works out well in the best of all possible worlds. In some future estate, there will be a perspective by which our seeming misfortunes are rendered blessings. Three problems attach to this. One is that although the future may enable us to overcome or even forget the past, it cannot on these terms be said to justify it, as if what once cursed us was merely a blessing in disguise. (Curiously, many clichés and expressions of speech that we carry with us are overloaded with notions of a divine providence, as in the old Scots adage, "What's for you, will no go by you.") Second, this epistemological perspective is not ours, at least not yet. We have to assume it in order to offer this type of

\footnotetext{
${ }^{12}$ Hugh Blair, "Of Our Present Ignorance of the Ways of God," in Scottish Philosophical Theology, David Fergusson, ed. (Exeter: Imprint, 2007), 84. A distinguished preacher and minister of St. Giles in Edinburgh, Blair was also the first holder of a chair in English literature. His sermons went through numerous editions in the nineteenth century and were translated into Germany by Schleiermacher.
} 
response, and this we cannot do simply as an interpretation of what is presently accessible. The surd element in human existence is not adequately acknowledged. The extent to which our lives are torn apart by accident or sheer bad luck seems missing. The dysteleological nature of suffering is not fully registered in Blair's reflections. This kind of pastoral exhortation, for all its elegance and genuine sensitivity, seems strangely out of place after the traumas of the twentieth century. Third, from a christological perspective we have to regard this world not as perfectly ordered but in need of its redemption. The doctrine of providence must also take a cruciform shape rather than appear as a theology of glory in which everything is already perfectly in place.

A further reason for a greater caution than is apparent in many speculative accounts of providence is our awareness of the ways in which these have too readily been co-opted for imperialist and totalitarian projects. Again, much of this reflects the twentieth-century experience. In Politics as Religion, Emilio Gentile shows how many of the political entities that have emerged in modern times have tended to appropriate religious symbols, myths, and rituals drawn from older faith traditions. ${ }^{13}$ This is true particularly of fascism, communism, and Nazism, but also of the civil religion that continues to manifest itself in Western democracies. Within the rhetoric of these political regimes, there were powerful but problematic claims to be the vehicles of divine providence in world history. Saint-Simon remarked on his deathbed that religion can never disappear from the world but only transform itself. ${ }^{14}$ This is apparent in the manner in which a wide variety of political movements functioned in a religious manner, seeking to mobilize the masses by the use of religious rhetoric and ideology.

The term civil religion was first coined by Rousseau to describe the ways in which a religion - with its stories, rituals, festivals, and symbols - might serve to foster a sense of communal identity and so articulate the primary political loyalty of citizens. ${ }^{15}$ For Rousseau, the dogmas of a civil religion had to be "few, simple, and exactly worded, without explanation or commentary." He proposed the following, "The existence of a mighty, intelligent and beneficent Divinity, possessed of foresight and providence, the life to come, the happiness of the just, the punishment of the wicked, the sanctity of the social contract, and the laws."16 Civil religion must also have a tolerance threshold. Without this, religion will

\footnotetext{
${ }^{13}$ Emilio Gentile, Politics as Religion (Princeton: Princeton University Press, 2006).

${ }^{14}$ Quoted by Emilio Gentile, Politics as Religion, 30.

${ }^{15}$ Jean Jacques Rousseau, The Social Contract, trans. G. D. H. Cole (London: Dent, 1973),

Book 4, Chapter VIII, 276.

${ }^{16}$ Ibid.
} 
undermine rather than promote social harmony. The only feature of a religion that must be proscribed is intolerance. ${ }^{17}$

Something of this is echoed in Jefferson's inaugural addresses and of the way that American history was subsequently woven into a discourse that expressed a sense of divine providence through a mission to the rest of the world, a testimony to political freedom, and the heroic sacrifice of the war dead. National acts of thanksgiving for the general and special mercies of the Creator were thus elicited. As a promised land for refugees who found freedom, dignity, and happiness amidst their ethnic and religious diversity, America could articulate through the nineteenth century the distinctive tenet of its civil religion. Through the traumas of the Civil War, Lincoln could interpret the sacrifices involved partly as a divine chastisement and partly as a regeneration of a national mission.

In Europe, civil religion functioned somewhat differently but with close parallels. The British imperial project was reinforced through much of the nineteenth century by the conviction that this was a divinely appointed mission that rendered an important service to other parts of the world. Religion thus not only promoted internal civic life but legitimized imperial expansion, much of the appeal being again to divine providence. Wilberforce, the evangelical reformer and leading abolitionist, argued that the opening of India to the imperial venture was itself providentially organized. The renewal of the East India Company charter in 1813 enabled Wilberforce and the Clapham sect to campaign for the insertion of the so-called pious clause in the parliamentary act, which required formal support for Christian mission in the subcontinent. Petitions were submitted to parliament. These had amassed almost half a million signatures, much of the supporting campaign drawing heavily upon notions of divine providence. Robert Hall, a Baptist minister, claimed that "our acquisition of power has been so rapid, so extensive, and so disproportionate to the limits of our native empire, that there are few events in which the interposition of Providence may be more distinctly traced." 18

The difficulties surrounding civil religion are not too hard to identify. Michael Walzer has noted that it tends to work best when it is least like a religion. ${ }^{19}$ In other words, its tenets and rituals are more likely to be widely embraced when these are of a minimalist nature. Civil religion requires as a social consensus a

\footnotetext{
${ }^{17}$ Ibid., 276-77.

${ }^{18}$ Quoted by Stewart J. Brown, Providence and Empire 1815-1914 (Harlow: Longman, 2008), 37.

${ }^{19}$ Michael Walzer, On Toleration (New Haven: Yale University Press, 1997), 77.
} 
theological minimalism, but what happens where this does not exist? Although it may be possible to incorporate Jewish and Muslim citizens into a piety of creation and providence, civil religion will inevitably struggle in societies where there are higher levels of secularism and outright disbelief. These of course may be in a minority, but arguably much of western Europe is now in this position. A further difficulty arises when the terms of a civil religion imply an exceptional mission under divine providence that is not given to other societies and nations. As Walzer again points out, its domestic effects may be benign, but these can spill over into national hubris with bad side effects. "Civil religion often makes for intolerance in international society by encouraging parochial pride about life on this side of the border and suspicion or anxiety about life on the other." ${ }^{20}$

Philosophies of history have often sought to offer an account of progress in history whereby it has a forward momentum gathering up each contingent event and episode into a narrative that moves inexorably toward a grand conclusion. The most famous of all such accounts is Hegel's, although he admitted that we can detect this pattern only with the benefit of hindsight. "When philosophy paints its grey on grey, then has a shape of life grown old. By philosophy's grey on grey it cannot be rejuvenated but only understood. The owl of Minerva spreads its wings only with the falling of the dusk."21

In one important respect, Hegel's is a deeply Christian philosophy. Unlike all the great philosophers who preceded him, he finds in history the key to the meaning of our existence. This must owe a great deal to the Judeo-Christian heritage and its claim that God's purposes are revealed and enacted temporally. Divine revelation unfolds in history and can be known via the testimony of the past. So historical and philosophical knowledge are intertwined on this account. In other ways, however, this is far removed from a fully Christian account of providence. First, it appears to subordinate the claims of each individual to the greater good of the whole. If we find ourselves trampled amidst wars of conquest, this may serve some grander purpose being enacted across history. Yet it seems far removed from the biblical concern for those on the margins, the excluded and dispossessed who are privileged by the prophets in their teaching and by Jesus in his lifestyle. This commitment to people and groups on the underside of history seems curiously lacking in Hegel's great project. A second anxiety with any progressive account of history is that it presupposes an immanent purpose being worked out inexorably within human events. Yet this leaves out much of the

\footnotetext{
${ }^{20}$ Ibid., 76.

${ }^{21}$ G. W. F. Hegel, Philosophy of Right, trans. T. M. Knox (Oxford: Oxford University Press, 1952), 13.
} 
apocalyptic element in scripture and tradition. Here events have an unpredictable tendency to take a turn for the worst, to produce crises, contradictions, and disharmonies within nature and history. Only God can remedy this eschatologically, acting from above and beyond rather than through a gradual process of cosmic evolution. At this point, Hegel and every progressivist philosophy of history seem at odds with an important element of the Christian tradition.

As an alternative, however, personal introspection is not in itself the primary index to divine providence, although this is not to deny that there may be some important signs of God's grace evident in our individual lives. Indeed, it is hard to imagine a life of faith without these. Nevertheless, we should not seek to make of our lives microcosms of a Hegelian philosophy of history or a Stoic account of nature in which every event inherently serves some wider pattern that God is working within us. There is much that happens to us that is the result of good and ill fortune, external circumstances in which we find ourselves constrained, and of course our own failings and limitations. To attempt to see all these as directly from the hand of God or as fated misses the significant role exercised by these forces in the created order. To say that we have no regrets in life, as I heard a distinguished Christian philanthropist once claim, seems naively triumphalist. Or to claim simply that everything is meant to be and must be for the best in the best of all possible worlds is unduly fatalist.

Much Protestant literature has of course proceeded along these lines, with attention devoted to the inner spiritual development and personal biographies of the faithful. The hand of God is detected in everything that happens so that some pattern must be discerned or interpreted. This can lead to some quite frivolous speculation in the event of good fortune, such as God's reserving a parking place for me, or crushing disappointment and disillusion when things suddenly go wrong for us. Why is God doing this to me, especially when I have tried to lead a faithful and upright life? Jesus' remarks about the fate of those who were crushed by the tower of Siloam and his reflection on the man born blind suggests that there is no direct divine correlation between the merits of our actions and the fate we suffer. Each event may provide a fresh opportunity for serving God or deepening faith, but it is important to distinguish this from the (more Stoic) claim that these events are directly visited upon us to exercise some hidden blueprint.

A fuller treatment of this aspect of the topic would need to consider the ways in which human beings appear incurably superstitious. Notions that we can manipulate God (or some pagan surrogate such as fate, destiny, or fortune) abound in activities that are inherently unpredictable simply because of their complexity or because we lack adequate knowledge of causal processes, or because of the way 
in which outcomes are finely balanced. The National Lottery in the United Kingdom has played on this superstition, with its publicity suggesting that this may be the night of all nights when fortune has fingered us for a life-transforming windfall. Most of us will have little difficulty in recounting pastoral circumstances where people sought to manipulate divine providence by their actions, often with the very best of motives. I can recall once being asked to bless a new house because the couple who were living there were experiencing fertility problems. We know that sports personalities are inherently superstitious and religious, sometimes because this is thought to give them a competitive advantage. Some golfers will silently pray before making a crucial shot, as if God was likely to reward them for their piety, thus presumably punishing an opponent who plays without such invocation. A story is told of the famous baseball catcher Yogi Berra, who waited behind an incoming hitter. When his opponent proceeded to cross himself before receiving the first pitch, Berra quietly said to him, "Why don't you just let God enjoy the game?"

\section{Providence in scripture narrates an account of the God-world relationship} that is described often in covenantal terms. Although asymmetrical, this relationship is one of codependence and is threatened by human failure and the turbulence of natural forces.

In making this claim, much that is latent in the traditional doctrine of providence is called into question on grounds of scriptural adequacy. This has become particularly apparent through recent encounters with Jewish exegesis of the Hebrew Bible. The assertion that God is in some sense dependent upon creation is of course in tension with much of what has traditionally been held about divine aseity and impassibility. This aspect of the tradition is important in pointing to ways in which God is quite unlike creatures and thus establishes in creation a set of relations that are asymmetric. Nevertheless, the surface narrative of scripture strongly suggests that these relations are marked by codependence and a relative autonomy of parties.

In recent works by commentators such as Brueggemann and Fretheim, there is a corrective stress on the relationality of God with respect to creation, a relationality that is often expressed though not exhausted by the language of covenant. References scattered throughout the Hebrew scriptures suggest that God is a relational being by virtue of the divine community that God inhabits. Later Christian theology has been nervous around these allusions, particularly because they seem to threaten an exclusive monotheism. However, we read of the divine council, the sons of God, heavenly messengers, and a celestial wisdom (Gen. 1:26; Isa. 6:8; Jer. 23:18-23; Prov. 8: 22-31). Whatever their ontological status or function, it is 
clear that they underscore the strong scriptural sense of God existing in a communicative relationship with other conscious beings and as being properly characterized in personal and relational terms. Biblical metaphors for God are generally personal rather than impersonal, often making use of quite anthropomorphic and anthropopathic language. Fretheim classifies these metaphors generally as personal, ordinary, concrete, everyday, and secular. In other words, they typically draw upon the mundane world of social life to characterize the identity of God in relation to the world. He notes that even nonpersonal metaphors tend toward a relational aspect. "I bore you on eagles' wings and brought you to myself" (Exod. 19:4). The giving of the divine name to Israel also intensifies the covenant relationship entailing further possibilities of encounter and communication. At the same time, however, it also makes God's honor vulnerable to the misuse of that name.

The Hebrew prohibition of images, moreover, is not cited to protect God's ineffability or unknowability so much as to misrepresent God's relatedness. The idols "have mouths, but do not speak; eyes, but do not see. They have ears, but do not hear; and there is no breath in their mouths" (Ps. 115:5-7). Unlike the false gods, as in the contest on Mount Carmel, Israel's God is one who lives and therefore can speak, hear, and act. As such, this God is also the creator of the world, living in relation not only to Israel but to all the families of the earth (Gen. 12:3). The affirmation that "God is" or "God lives" is explicated in dynamic, personal, and relational terms by the Old Testament. Here God is not approached by a philosophical via negativa or an abstract account of the most perfect being, so much as through a tradition of divine-human exchange.

The relationship of God to creatures is expressed, moreover, through a system in which all creatures are interrelated in a cosmic whole. God does not relate to us merely as individuals but as persons who exist in relations to one another and to the wider environment. The social and natural order of the world is deeply connected in ways that affect God also. This is a recurrent theme in the Psalms and the prophets. "The land mourns and all who live in it languish; together with the wild animals and the birds of the air, even the fish of the sea are perishing" (Hosea 4:1-3). One feature of this web of life is that we have a system that is neither chaotic nor deterministic. There is a rhythm that is natural to it in the regularity of the seasons, the succession of day and night, the movement of the planets, and the universal patterns of life and death. The world is God's good creation. At the same time, however, there is "no little play in the system." 22

\footnotetext{
${ }^{22}$ Terence E. Fretheim, God and World in the Old Testament (Nashville: Abingdon, 2005), 19.
} 
Within the order of the cosmos, there are events that appear random, surprising, and surd. There are forces, sometimes within us, that threaten the harmony and delicate complexity of life. Although good and worthy of celebration, the world is not yet a finished project; it remains a site under construction. The closing speeches of the Book of Job explore this duality of divinely bestowed order threatened by untamed forces. This ambivalence of God's world needs to be registered by an adequate doctrine of providence.

If we think of God's calling into being as an interconnected world established in a continuing relationship with its Maker and Redeemer, then we can attribute a proper place to creaturely action, initiative, and power in ways that reflects the codependence of God without lapsing into synergism or Pelagianism. The divine-human relationship is asymmetric in terms of its setting, yet it is one in which God becomes reactive and in important respects dependent upon what has been made. Within this conceptual space, activities such as prayer, obedience, rebellion, forgiveness, redemption, and blessing now become possible. Fretheim writes, "God works from within a committed relationship with the world and not on the world from without in total freedom. God's faithfulness to promises made always entails the limiting of divine options. Indeed, such is the nature of this divine commitment that the relationship with Israel (and, in a somewhat different way, the world) is now constitutive of the divine identity. The life of God will forever include the life of the people of God as well as the life of the world more generally." ${ }^{23}$

What this suggests is that there are at least two aspects of providential reflection in scripture. Roughly speaking, these correspond to a general and special providence, although the tension between them has often been overlooked. In one aspect, the order of the world reflects the divine wisdom. The regularity of day and night, the seasons of the year, and the provision that is made for creatures all attest to the covenant faithfulness of God (Gen. 8:22; Ps. 104). This order is experienced in the daily rhythms of life creating stability, well being, and human flourishing. It is closely aligned with respect for God's law in the Psalms and Wisdom literature. Elements of New Testament teaching draw upon this tradition, especially the teaching of Jesus in the Sermon on the Mount. God's gracious provision is for all creatures, relieving us of unnecessary anxiety (Matt. 6: 25-34). At the same time, scripture presents the social and natural world as being threatened by disruptive elements. Its order and design are often concealed and disturbed by the forces of sin, suffering, and evil. These are contested by the

${ }^{23}$ Ibid., 20. 
action of God in patterns of struggle, resistance, and redemption. The purpose and rule of God are not wholly apparent, as Job and Qoheleth suggest. Here providence is described more dialectically, its discernment becoming difficult even within the lives of the faithful. God's regime is hidden in ways that are troublesome. In the experience of exile, it becomes difficult to identify what God intends or does. Yet this does not result in a suspension of belief; instead, it is the occasion for fresh and deepened affirmation. "Indeed, in its countertestimony, Israel used the occasion of Yahweh's hiddenness to magnify its claims for the generous, creative, and faithful governance of Yahweh." 24 This more dramatic and interactive account is apparent in Paul's remarks about the foolishness of the cross, by which God's wisdom is displayed in ways other than the standardized norms of power, such as those depicted in Greek philosophy (1 Cor. 1:18-25). By contrast, the world is redeemed through the cross, the paradigmatic image of divine weakness and dependence upon the created world. The event of Jesus's crucifixion is itself part of the cosmic whole, but a part that is proclaimed to determine its identity and final outcome. Yet the subsequent preaching of this gospel and the spread of the Church are also viewed as expressing a divine purpose within history, "a plan (oikonomia) for the fullness of time, to gather up all things in him, things in heaven and things on earth" (Eph. 1:10).

One feature of this array of scriptural allusions to divine foresight and provision is that it is misleading to restrict the doctrine of providence to a subdivision of the doctrine of creation. Its standard textbook locus has not served an account of providence well. It is a feature of all three articles and suggests the need for a differentiated account of divine action in any adequate account of providence. A Trinitarian account of providence might usefully assist us in this respect by presenting it in ways that are not dominated by a single model appropriated to the first person. ${ }^{25}$

\section{If we know the content and scope of God's providence from contemplating} the history of Israel and its fulfillment in the person and work of Christ, then the signs of providence will begin here and spread outward into the cosmos. Yet in discerning these we remain within the circle of faith.

God's providence in our lives is most evidently displayed not in material success, health, or other forms of prosperity. It is best evinced in the knowledge of

\footnotetext{
${ }^{24}$ Walter Brueggemann, Theology of the Old Testament (Minneapolis: Augsburg Fortress, 1997), 357.

${ }^{25}$ This is argued in recent studies by Reinhold Bernhardt, Was heisst 'Handeln Gottes'? Eine Rekonstruktion der Lehre von der Vorsehung (Gütersloh: Kaiser/Güterloher, 1999); and Charles Wood, The Question of Providence (Philadelphia: Westminster John Knox, 2008).
} 
the forgiveness of sins and in the power of the sanctifying Spirit. Providence is evident less in what happens to us than in how we live "amidst the changes and chances of this mortal life." Its center is in the church's life of praise, confession, supplication, and obedience. From there, we can understand the course of our lives and our world as governed by God's good providence. But this must remain an expression of faith rather than a psychological insight, a cosmic vision, or a political philosophy. In this way alone, we may believe and look for the signs of God's good creation, the redeeming work of Christ, and the coming kingdom everywhere around us. These can be discerned variously in the rhythms of life, the grace discovered in our lives, gifts of human friendship, and even in political states that achieve a measure of justice, civic harmony, and peace for their citizens. But our discernment must always be partial and often reserved amidst the shadows and imperfections of the world. It must proceed outward from the center of faith predicated upon "foolishness of the cross."

So what we have here is something like the rudiments of a chastened and deflationary doctrine, yet one that strives to be scripturally faithful and adequate to the pastoral needs of the church. It was this impulse that drove Karl Barth to the claim that the clearest signs of providence in the history of the world are the preservation of holy scripture, the witness of the Jews, and the survival of the church ${ }^{26}$ What is surprising about this list is perhaps its modesty in relation to grand schemes of history. He does not speak about the rise of democracy in the modern world, the demise of Hitler's regime, or the birth of the United Nations. Only those events and circumstances that stand most closely in relation to the light of Christ can be represented as tokens of God's providence.

However, as we have already seen with respect to the Hebrew Bible, the rule of God is not confined to Israel or the church. It extends outward from this central action to the entire created world. In this respect the distinction between works of special and general providence may have a place. The work of salvation determines not only the community of the faithful but the whole cosmos, and this must include the natural world and our rootedness in it. To that extent, we can rejoice in the regularities of nature and the rhythms of life as echoes of God's goodness, those phenomena that have often been classified as works of general providence. Given the unity of scripture, the single economy of creation and salvation, and the cosmic scope of Christology, there must be a place for this in the life of the church as well in the life of Israel. So the created order can be celebrated for its goodness, as can our physical and social life as belonging to it.

\footnotetext{
${ }^{26}$ Karl Barth, Church Dogmatics III/3, trans. G. W. Bromiley and R. J. Ehrlich (Edinburgh:
} T\&T Clark, 1960), 200ff. 
Particular events may also resonate with God's purposes and be received gratefully in this light—birth, marriage, and sometimes even death—but their reception as such must always be provisional and tentative. To the extent that they forward Christ's purpose, they can attest God's rule. But our vision is partial at best and our confession at this juncture remains a modest one. Even within the good creation there is also decay, disease, and the shadows of life as well as cruel misfortune together with the insidious and widespread effects of sin. Christian faith requires us to think of the same world as both providentially ordered and yet also fallen. In celebrating God's providence, the psalms live with this tension as also does Job, a book too often neglected in the church's theological reflections.

Social and political harmony may also be interpreted rightly as signs of God's providence insofar as these are intended by God, made possible now in part, and promised more fully. Isaiah's vision of international peace is a celebration of God's coming providence that determines our political and social life already (Isa. 2:2-4). But this cannot confer upon any one political program or epoch a privileged instantiation of divine providence. History is littered with examples of groups and nation states that claimed too much for themselves often at the expense of others.

\section{Concluding Postscript}

Can we speak of everything that happens as willed by God? Classical Reformed dogmatics did this by reference to the threefold pattern of divine action: preservation, concurrence, and overruling. But we should speak of the divine will only in a clearly differentiated manner. Insofar as the world is created and sustained by God, it exists in its totality by the divine will. If this entails that every event is permitted by God, then we cannot shrink from speaking of everything happening in accordance with the divine will. At the same time, if everything that happens can create an occasion for some redemptive prospect, then we cannot say that any event lies irrevocably outside the providential rule of God. However, what must also be said, and perhaps more clearly than before, is that the nature and purpose of God's action in redemption produce a criterion by which the divine will is to be measured. And in this respect, there is clearly much that happens that cannot be said to be God's will. On the contrary, the setting of God's will in Christ must entail that God rejects all that is not in conformity with this. The classical doctrine said too little in this respect, thus creating the impression of an inscrutable and impersonal sovereign will. Here we must eschew any appeal to hidden explanations, as in Blair's sermon cited above, and admit that there is a surd element in life that is incomprehensible. 
Whether answers are what people need is in any case doubtful. Would it help to cope with the loss of a child to learn that it fitted some overarching scheme, the details of which will someday be made clear to us? What is needed is strength to keep going and the hope that Christ's victory will finally gather together all that God blesses in our lives. In this respect, the doctrine of providence needs to be found even more serviceable on bad days than on good. "For all we can tell, may not we ourselves praise Him more purely on bad days than on good, more surely in sorrow than in rejoicing, more truly in adversity than in progress?"27

This seems to me one mistake made by much modern criticism of religion. If the cosmos contained only order, with good consequences for everyone, we would find it easier to believe. This is an assumption of much current secular attack on faith. Yet faith seems to flourish on stonier ground; we need it more and it serves us better in times of suffering and struggle. Many of the great hymns of providence were written in times of threat, pain, and fear. Luther's "Ein' Feste Burg" is the hymn of a beleaguered church threatened by political uncertainty, Rinckart's "Nun danket alle" was written for his community at a time following plague and heartbreaking loss. George Matheson's "O Love That Wilt Not Let Me Go" was composed amidst the onset of blindness. Such hymns of providence succeed when attention is directed toward the Christological center of faith and then works outward and inward; in doing so, they prevent a lurch into speculation or sentimentality, or a premature closure on the problems.

${ }^{27}$ Church Dogmatics III/3, 297. 


\section{Politics in the Christian Life}

by Robin W. Lovin

Robin W. Lovin is a professor of ethics at Southern Methodist University in Dallas, Texas. He delivered this lecture at the Center for Theological Inquiry on March 15, 2007.

\section{$T$}

he relationship between religion and politics is a topic that gets a lot of practical political attention these days. Campaign strategists who used to keep signs on their walls that said, "It's the economy, stupid!" are now trying to get candidates to open up and talk about their faith and scatter words like "righteousness" and "spirit" and "covenant" through their speeches. More generally, the growth of religious political activism has raised questions about accepted understandings of church and state, and where "faith-based initiatives" fall between them. There are controversies about religion in the public square, both metaphorically and often quite literally as a question about what kind of religious symbols or monuments should appear on public property.

The questions are various, and the discussions often produce more heat than light, but one thing you will notice is that in most cases the issue in the popular discussion is about how religion should fit into politics. My concern tonight is with a different question, one that seems to get less attention. I want to explore how politics fits into the life of faith. My question is not whether the public square should be open to religion but how religious people should feel about being in the public square. The odd thing is that neither the people who are rushing to inject religion into contemporary politics nor those who are trying to bar the door and lock the gates to keep religion out of politics seem to have given much thought to the question of politics in the life of faith, which is certainly older, and arguably more important than the questions about faith in politics. 
In fact, thinking about politics as part of the moral life is probably the original form of the political question in Western civilization. Twenty-three hundred years ago, Aristotle began his treatise on politics with the assumption that politics and ethics are parts of the one discussion about what makes a good life for human beings. How should people live in order to have a good life over the long run? And what kind of communities do they need in order to live that way? Ethics, for Aristotle, was about acquiring the virtues that make it possible for you to live a good life as an individual, and politics was about organizing the whole city in ways that encourage that virtuous life and bring virtuous people forward as leaders.

Probably actual politics in ancient Athens did not correspond very closely to that model, even for the minority of free, adult, male citizens who had the opportunity to live according to Aristotle's design. (That minority, by the way, did not include Aristotle himself, because he was a foreigner-perhaps the original example of a highly talented guest worker being brought in to do a job for which no Athenian appeared to be fully qualified.) The Athenians may not have lived up to Aristotle's vision of politics, but at least no one who understood Aristotle's ethics had any reason to doubt that politics was part of the good human life. Politics was not a morally suspect activity, and ethics was not a set of rules for investigating committees to impose on politicians who got out of line. Politicians were fundamentally concerned about ethics in their political decisions, and people who were trying to live a moral life could not do that fully without participating in politics.

The question about religion and politics arose later. It's hard to say exactly where and when, but we can see it clearly in the work of Augustine, Christian bishop in the Roman city of Hippo in North Africa beginning in the year 395. Augustine was something of a politician himself. He began his career as a professor of rhetoric, which was a cross between what we today think of as a lawyer, a philosopher, and a professor of political science. Augustine became a Christian under the guidance of Ambrose, the bishop of Milan, who had himself been a Roman magistrate before he became a bishop. When Augustine returned to his home in North Africa to lead the churches there, he found that the power of Roman government was in decline, and like other bishops in the Western church, he had to be not just the preacher but also the judge, recorder of deeds, and commissioner of public works for his community.

Several things made Augustine's community different from Aristotle's, apart from the 700 years that separated them in time. For one thing, Augustine's world was religious in a way that Aristotle's was not. In Augustine's time, people 
had a much stronger conviction that their lives had a spiritual dimension that belonged to them as individuals, apart from the religious rituals that their tribe or their city observed. And in Augustine's world, they did not all share the same religion. Conflicts over religion could, in fact, be quite fierce, not only between Christians and the worshippers of the old Roman gods or the initiates of other religions but especially between different groups of Christians.

In that conflicted and sometimes violent world, Augustine developed a different, more realistic understanding of politics. Politics, realistically considered, was not about what makes a human life good as a whole but about one quite specific human good - that is, peace. This peace, moreover, was not the peace, harmony, and well-being that the Hebrew scriptures have in mind when they speak of shalom. It is the more minimal peace that people share when they stop beating up on one another, or-more precisely-when they have someone in authority to make them stop beating up on one another.

So the reason why people engage in politics is not that they want to be good people but that they want a little space of peace and order in which they can then do all the other things that they think will make their lives good. Augustine had a more limited idea of politics than Aristotle did, but he still put a very high value on it. Augustine lived in a violent time, when the older foundations of Roman law and order were breaking down, and he spent a great deal of his life trying to secure some sort of civil peace, even when that involved him in some fairly brutal persecutions of the people he thought were threatening it. He had no patience with Christians who were squeamish about the requirements of order or who thought they operated on a spiritual level that was above these political matters. Making the hard decisions that justice requires and enforcing the rules on which justice depends is something that Christians owe to God and to their neighbors.

Augustine's ideas about politics in the life of faith endured for a long time, and on this point, as on many others, Luther's Reformation, which came about eleven hundred years later, did not mark a radical departure from Augustine's version of Catholic Christianity. Luther, too, emphasized the importance of order and the religious obligation of Christians to do their part in maintaining it. Luther asks the question at one point whether a Christian can be a hangman, and his answer, while harsh, should come as no surprise if you've read Augustine. Of course, a Christian can be a hangman. There are people out there who need to be hung. It's a public service, and if you're qualified, you ought to make yourself available to do the job. We should not mistake this for one of our contemporary arguments about capital punishment, which Luther in 1523 had no idea of 
entering. The point for him is a more general one. Being a hangman is a sort of entry-level public service job. What's true of the hangman is true for everybody involved in politics - the tax collector and the judge and the chancellor and everybody right on up to the king: they serve God and humanity not by doing good but by restraining evil. In a disorderly world, theirs is the essential task of securing peace by providing order. We should not expect too much more than this from our politics, and we should neither underestimate the difficulty of this task of order nor underrate those who provide it.

In the long arc of history from Aristotle to the beginning of the modern world, it's clear that the idea of politics is greatly changed. It goes from being a comprehensive search for the human good in all its aspects to being the search for one quite specific good, namely, civil peace and order. People still sought all sorts of human goods in all sorts of different ways, but they came to think of politics more narrowly as using power to maintain peace. The good secured by politics is different from other goods. It's a good that can be imposed on people who don't want it. Learning and piety and all sorts of virtue require active involvement by those who want to participate, but the agents of order impose it on the willing and the unwilling alike. Indeed, peace has to be imposed on people who don't want it, or there would be no peace for the people who want to pursue other goods in other ways.

Thus, by the end of the sixteenth century, politics had already taken on its modern meaning as something narrowly associated with the work of government. This kind of politics has a place in the life of faith, not as virtue or as a capacity that is connected with spiritual development but as a form of service to others, who get to live in peace and security because Christian leaders exert themselves in these political labors. It is perhaps even a service to those who are brought under control by law and the exercise of political power, in that they are prevented from doing the evil they would do if left to their own devices. Although they don't necessarily become good people, they are at least not as bad as they otherwise might have been.

The person who benefits least from political power, it seems, is the person who holds it. Both Luther and Augustine were quite clear about that: political power tends to be corrupting, and those who exercise it, even if they manage to stay honest, run the risk of dangerous miscalculations that lead them to punish the innocent or destroy the peace they are trying to preserve. Not very much about our modern-day politics would surprise Luther-certainly not the bribery and corruption scandals, nor the people who are freed from prison years after being wrongfully accused and convicted, nor the fact that sometimes when the politicians send 
in a peacekeeping force, the level of violence actually increases. Yet Luther would insist, as Augustine did before him, that this kind of politics still has a place in the life of faith. Serving the neighbor is what people of faith do, even when it turns out to be difficult and morally ambiguous.

Just at that point, however, some people of faith began to look at the question in a different way. They agreed with Luther and Augustine that politics is difficult and morally ambiguous, but they then asked the question whether Christians have any business serving their neighbors in just this way. Perhaps politics and government are not forms of service at all but are tempting forms of pride and power-especially for those who live at the upper reaches of the political order: the kings, generals, and judges. But if Luther had it right, these critics said, then it's really the hangman who shows us what this "public service" is about. It rests on violence and not on love. It has everything to do with pride and power, and nothing at all to do with the life of faith.

The people of this sectarian movement that historians sometimes call the "Radical Reformation" lived what they preached. They endured persecution from Christians with more orthodox ideas, and they often preferred to withdraw from society rather than enjoy a political peace that was purchased by coercion and violence. For several centuries, their descendants sought out less populated corners of the world in central Europe, or in Russia, and later on the frontiers of the United States and Canada and in Central and South America. We can see them today in the Mennonites and in Amish communities that practice pacifism, simple living, and strong communities of mutual support that make government services largely irrelevant.

Now, I want to pause here for a moment, somewhere in the middle of the sixteenth century, to summarize where we are in the story. Aristotle's linking of politics and the human good gives way to the Augustinian idea that everyone seeks peace, and the Augustinian search for peace eventually becomes the modern idea of politics. And that new politics splits Christians into two distinct groups. It's at that point, well into the Reformation era, that the question of whether politics has any place in the Christian life becomes a live issue. At least from Augustine onward, Christians had understood that securing peace sometimes requires the use of force. But the modern idea of politics adds that the job of securing peace by force is the distinctive work of the ruler, or of a kind of organized rule that people began to think of as "the state." Political theory, in fact, defines a state as a system of rule that exercises a monopoly on the use of force within a given territory. The rise of the modern state was itself part of the creation of modern politics, just as Luther's recognition that secular rulers had a 
distinct vocation, separate from the spiritual authority, helped to create the space in which modern politics could do its work. Once that realm of politics, the realm of coercive power wielded by secular authority, gets defined, Christians take two quite different attitudes toward it: they can enter into politics and seek its distinct goods of peace and order as a form of service to their neighbors, or they can reject it and focus on the cultivation of the Christian life.

So I pause here in the middle of the sixteenth century to summarize, but I also pause because if you understand the story up to that point, you already know most of what twentieth-century Christians have to say about religion and politics. (That's especially true for twentieth-century Protestant Christians.) That's not to say that there are no further changes in politics, but the relation between religion and politics, or between politics and the moral life, can still be understood in the framework that gets set up during the Reformation. The absolute authority that Luther gives at first to the secular ruler changes, even within Luther's lifetime, to the idea of rule by law, and then the making and administration of law increasingly becomes a democratic process, undertaken by people who are understood to be free and equal. Modern politics expands beyond the ruler's court and the king's counselors to include constitutional conventions and bicameral legislatures, an independent judiciary, and an elected head of state. Subjects become citizens in a Lockean state, seeking an impartial judge who will follow the rule of law and spare them the "inconveniencies" of having to enforce their claims for themselves. The justice they seek comes not from an authority who will tell them what the right ordering of goods is but from someone who will settle their claims fairly, according to rational principles of justice that the parties have accepted for themselves. Instead of awarding the goods at issue to the most virtuous, the modern judge tries to balance competing interests fairly, without deciding which side has made the best choices. What the state pursues is justice defined by law and not the human good determined by religion or morality. If you can free yourself from a certain Enlightenment bias that says that political liberalism was all about replacing religious conflict with rational, secular choices, you can see that modern politics of liberal democracy is the lineal descendant of the distinction between secular and spiritual authority that Luther made at the beginning of the Reformation.

Most Christians since the beginning of modern politics have made a place for it in Christian life. They have served in the military or worked in law enforcement. They have been judges, lawyers, civil servants, and social workers, without any sense that this service to public order was in conflict with their Christian commitments to love God and their neighbors. They have voted in elections, paid 
their taxes, and, on the whole, chosen their leaders for their policies and not for their piety. (However, according to the latest polling data, a candidate's morality also seems to figure in the choice.) In different times and places, Christians have been in different relationships with their governments, adopting positions that ranged from unquestioning loyalty to active resistance. Especially in the last few decades in American churches, the range of political opinion has become quite wide and contentious. Congregations have been divided over public issues about human rights, war and peace, abortion, marriage, and the family. And certainly clergy have learned to tread warily through the minefield of conflicting beliefs. So it's worth emphasizing that although the people in our churches have many different opinions on the issues, most of them continue to share, without even thinking about it very much, this modern understanding of politics and government, and they share Luther's idea that participation in that sort of politics is a Christian duty. (They would prefer, if possible, something better than the entry-level hangman position that Luther offered but are willing to accept his basic point about service to their neighbors.) They continue to argue with one another-and with their pastors - about policies, but they do that because they think politics has a place in the Christian life.

This acceptance of modern politics has, however, come under challenge in recent years by theologians who argue that the coercive power on which the modern state rests is incompatible with the Christian commitment to nonviolence. The civil peace that can be secured by force simply isn't anything like God's shalom, and people of faith ought not do things that might lead other people to confuse them. If you argue that modern society just wouldn't work if all the Christians quit participating in politics, Stanley Hauerwas will answer that Christians are called to be faithful, not effective. The church's role is not to make modern politics work. It is to witness to another possibility altogether.

This is in some ways a new thing in American theology that Stanley Hauerwas, Stephen Long, Bill Cavanaugh, and others have put on the theological landscape in recent years, but it has its roots in that rejection of modern politics that was the Radical Reformation's answer to Luther. If modern politics is something different from the Christian life, perhaps something even in tension with the basic requirements of the Christian faith, then why not just turn your back on it altogether, instead of embracing it as a form of service? Perhaps the greater service is to remind people of the limits of politics. Hauerwas, who sometimes calls himself a "high church Mennonite," acknowledges these Radical Reformation sources of his thinking, and certainly the late John Howard Yoder, the leading twentieth-century Mennonite theologian, has significantly influenced 
both Protestant and Catholic representatives of this Christian witness against the assumptions of modern politics.

So far, then, a closer examination of current trends in theology and church life tends to confirm my initial judgment that we learned everything we know in the sixteenth century. What seems to be different, however, is a certain kind of conservative religious activism that today openly seeks a government led by Christian leaders and organized on Christian principles. I am not here speaking of those who might organize politically to promote a specific policy that they regard as more Christian than the alternative proposals-say, a ban on gay marriage or partial-birth abortion. More-liberal Christians, after all, organize themselves politically around issues, too. I' $m$ talking about the movements that aggregate these individual issues into a broader program to give their understanding of Christian faith and morality a normative role in public life. The organizations and leaders cover a spectrum from, say, James Dobson of "Focus on the Family," who has simply concluded that ordinary political activism issue by issue isn't going to work and that things will continue to deteriorate until Christians organize to break down the barrier that separates Christian morality from public law, to biblical literalist visions like Roushas Rushdoony's Christian Reconstructionism, which advocates replacing modern politics with biblical law.

It seems to me, however, that when you get the history straight, these groups have more in common with the Radical Reformation rejection of politics than perhaps at first appears. They agree, after all, that modern politics is incompatible with Christian faith and life, but they locate the problem in a secularization of politics that begins with the Enlightenment, and not with the secularization that Luther introduced when he said that government and secular authority have distinctive purposes that shouldn't be confused with the spiritual authority and spiritual purposes of the church.

To tell the story that way, you have to find an America whose founders were uniformly committed Christians and whose vision of a Christian republic was at some point corrupted - by Thomas Jefferson in 1801, or by rationalist social scientists at the end of the nineteenth century, or by the Supreme Court in the 1970s, depending on who's telling the tale. It is a little difficult to get James Madison's theory or George Washington's practice aligned with that narrative, but if you believe you can do it, then the recreation of a Christian America becomes a return to the founding principles and not a violation of the First Amendment.

But the big problem for that narrative originates not with Madison but with John Witherspoon, a thoroughly orthodox Presbyterian theologian who understood the 
difference between Christian faith and republican politics (small "r") but thought that they were compatible in the same way that Luther thought Christian faith and secular authority were compatible. The vision of a Christian America is historically mistaken, not because not all of the founders were orthodox Christians but because most of the founders who were orthodox (small "o") understood the difference between faith and politics and nevertheless accepted modern politics as part of the Christian life.

Those who set their hopes on the creation or the re-creation of a Christian America share with their Anabaptist forebears the conviction that modern politics is incompatible with the Christian life, so that those who want to live the Christian life must go somewhere where they can organize life on their own terms. The Anabaptists did this, of course, by finding a place for their communities in isolated Alpine valleys, or in the vast unsettled lands of Russia, or on the new frontiers of North America and South America. On the whole, this was not the vision shared by the American colonists, especially in the Middle Colonies southward. But the image of a new land that would be God's kingdom on earth, or something much more like it, was a powerful motivation for many who settled this country, from the Plymouth colony in 1620 to the Mormon settlements in Utah in the early nineteenth century. Contemporary visions of a Christian America seek to retrieve this hope from the past, instead of finding a new place for it in the future, but they share a sectarian rejection of modern politics with other visionaries, exiles, and resisters in the tradition.

So, if it seems to you that the contemporary debates about religion in politics have become a little repetitive, with no one saying much that's new, it may be because the more basic question of politics in the life of faith is being argued today on terms that were already set at least 400 years ago. The issues change, but there's really only one question: Do you accept the terms of modern politics and the institutions of the modern state? If you do, you roll up your sleeves and try to make them work, not so much as a commitment of personal faith but as an act of charity to your neighbors. If you don't accept the terms, then you try to stand apart from those modern institutions as a separate community organized around a nonviolent alternative.

What I want to ask is whether this single question with its two opposed answers really exhausts the past or explains the present possibilities. I want to move the narrative ahead a century or two, to look at developments in post-Reformation Christianity that seem to have found a way to question modern politics without rejecting modern society. I'm going to try to identify that part of the tradition, briefly, but in enough detail that I think you'll recognize the characters and that 
will allow me to conclude by asking what it might contribute to our thinking about politics in the life of faith today.

Begin again, then, where we paused, in the sixteenth century. Some Christians are taking an active role in the work of emerging modern states. Usually they are the ones who share the right set of Christian beliefs to place them in a majority in their own territory, and this gives them access to positions of authority and power. Others question this new politics. They focus inward on communities of faith apart from the established church, or they look for a new place to set up their own vision of a Christian society, or they are pushed to the margins of political life because they have dissenting beliefs that exclude them from positions of authority and power. But farming communities in isolated Alpine valleys or transatlantic colonies were not the only places open to these marginalized Christians. Some migrated to the growing cities and found that there was much they could share with the other people they found there, even if these people didn't all share their version of the Christian faith. By the end of the 1600 s, the institutional landscape of Europe was much more complex than it had been at the time of the Reformation. The small, independent Protestant congregations that stayed clear of both Catholic and established Protestant connections were part of this development-but only part of it. Merchants, bankers, and traders were finding new ways to organize themselves to share risks and make money. Those who prospered in trade turned around and created new schools and cultural centers and social institutions.

In the English-speaking world, these changes were most rapid and most noticeable in places that were far from the old centers of political and religious power. Scotland and Ireland prospered in the 1700 s, before the famines that drove the great waves of migration to America. And in the same century, the Scottish Enlightenment had transformed Edinburgh, Glasgow, and Aberdeen into intellectual centers that far surpassed Oxford and Cambridge in their day. Something similar was going on up and down the Atlantic coast of British America, driven by many of the same groups of people. Congregationalists, Presbyterians, and Baptists, and later, Methodists first built churches, homes, and shops and then later built schools, concert halls, orphanages, and hospitals, though they were a little slow with the theaters and pubs. Those who flocked to the growing cities found their share of crime and misery, especially once the Industrial Revolution took hold, but they also found opportunities for themselves and their children. The modern world was creating a multiplicity of new institutions that offered ways to create human goods and ways to live the good life that hadn't existed in the medieval world and the age of Reformation. 
Perhaps the most effective participants and the greatest beneficiaries in these changes were those who stood outside of the traditional hierarchies of wealth, political power, and religion. In England, dissenters, independents, and evangelicals were at a social disadvantage, and it's worth remembering that many of them were barred from voting, holding office, or attending the universities because of their nonparticipation in the established church. In Britain, in fact, some of these disabilities persisted into the late 1800 s. Scots Presbyterians who were part of the established church did not have the same political disqualification that English dissenters experienced, but not all Presbyterians were part of the established church, and in any case, Scotland was politically marginalized after the union of the English and Scottish parliaments in 1707. Nevertheless, during the two centuries from 1600 to 1800 , these politically marginal people on both sides of the Atlantic found ways to make themselves more wealthy, better educated, and more effective in their philanthropy than the elites who initially regarded them with suspicion. By the time they began to demand political equality, they had their own ideas about what made a good society. Where Luther and Augustine had emphasized the importance of order in times of dissolution and conflict, John Wesley and Adam Smith emphasized practical collaboration on shared goods, which helped people be virtuous, as well as orderly. If the initial logic of the Radical Reformation favored withdrawal from the wider society, those who came later developed a strong sense of how much they had in common with other sober and industrious people and how much they had to offer to those who were neither sober nor industrious.

It would be hard to overestimate the importance of these developments for the future shape of religion and politics in the United States. On this side of the Atlantic, the marginal groups of English religion and politics became the mainstream. Congregationalists were, in fact, the established church in New England, and Presbyterians occupied a similar role in the Middle Colonies, but American Protestants retained the preference for voluntary associations, mutual aid, and private philanthropy that their traditions developed during their years of minority status in England. Those institutions shaped the ways that Americans sought the human good at least down to the beginning of the twentieth century, and probably right up to the New Deal. The American instinct for doing good involves a coalition of likeminded people pooling their resources and exercising their independence and good judgment. Legislation comes into the picture, if at all, only later. Whether that eighteenth-century model is still valid for twentyfirst century problems is matter of debate, but I'm not here to settle that question. My point is to remind you of the eighteenth-century model and why it is still such a powerful force in American life. 
Perhaps most important, although the people who developed the marginal model became the mainstream, their way of thinking about faith and life continued to provide those on the margins with a way of understanding their situation, exercising some control over their lives, and even influencing the direction of the wider society. Quite beyond the intentions of the American mainstream, and in some cases against their active resistance, the institutional models they had created became available to the very groups that they thought they needed to exclude, expel, or control. African Americans after the Civil War, European immigrants in the late nineteenth century, and women in the early twentieth century all found the model of free congregations, voluntary organizations, and a commitment to mutual assistance to be the key to a better life, and ultimately, the key to political empowerment. Indeed, Northern women schooled in those congregational methods became the mentors of other groups, through the Freedmen's Bureau and the settlement houses, and thus acquired some of the experience that helped them create the movement for women's rights. African American churches, colleges, and businesses replicated, with a distinctly American accent, the successes of the middle class non-Conformists in England a century or two before. None of these groups wanted to be excluded from political power, and all of them eventually found ways of acquiring it. But by the time they acquired it, they had learned that there were ways of shaping society that did not depend on success in modern politics.

So the question has to be asked, who understands politics better? Those who create order and exercise power at the center of modern politics? Or those who create new institutions at the margins, by which the center is eventually transformed? Who has a better understanding of the place of politics in the life of faith? Who, indeed, is more truly political? Those who understand the conditions under which people cooperate to create and maintain a whole variety of human goods? Or those whose definition of politics has been shrunk to the modern politics of order and public reason?

In relation to these questions, we might conclude that the most successful Christian politics has been the politics of this marginal Christianity, which developed in the space between the governmental politics of the magisterial Reformation and the resistant politics of the radical Reformation. A strategy learned in exclusion from the centers of modern political power has provided a way to sustain a whole range of human goods, make them available to wider circles of people, and in the end, to transform the social order itself.

Here, instead of modern politics, we have Aristotle's politics, continued by other means. There is no single deliberative body and no single system of rules 
that governs all discussions. Rather, there are many different institutional settings and a multiplicity of social spheres, each creating a discourse appropriate to its own goods and goals-religion and government, for starters, as well as education, commerce, and culture. The variety of shared human goods that are possible in the modern state creates a pluralistic politics, in place of the dualisms of secular and spiritual, or public and private. To understand the possibilities for politics in Christian life today, we need to develop this pluralistic model alongside the politics of public reason and the politics of witness that dominate the current discussion.

This political pluralism assumes that agreement on particular human goods is possible apart from a theology that orders all human goods in relation to God and one another. Shared experience of evils overcome and goods sustained shows that moral meanings are not completely dependent on a shared narrative of faith. If moral meaning depended strictly on a shared narrative, as the resistant politics of witness suggests, then Christian understandings of the good would be incomprehensible to those who do not share the narrative, as the resistant politics of witness insists that they are. But experience tells us that this simply is not so. People who want to fight disease, defend human rights, educate children, or make music together discover that they can do it, across very different cultures and very different understandings of what the ultimate destiny of human life may be. They sometimes stop doing it, if religious or political authorities tell them that it is a bad idea, for theological or for constitutional reasons, but the pluralistic politics of marginalized Christianity grew up very naturally, despite religious differences, and sometimes even in the face of religious hostility. The same experiences are repeated today on a global scale, across even larger gaps of faith and culture, and it is important to develop an understanding of politics that takes these cross-cultural, cross-religious experiences seriously, instead of confining them to a private realm, where they are locked into confessional religious narratives and allowed to emerge only after they have been translated into terms approved by of public reason.

That is the key to the pluralistic understanding of politics and society that emerged from the margins and eventually became the Christian center: human goods exist in the forms that people create and maintain in concrete social situations and in their interactions with one another across all the lines of race, religion, ethnicity, and class that initially divide them. There are a variety of ways to understand these human goods in relationship to God, and a variety of ways to order them by law, but they do not depend on church or state for their existence or for their meaning to the people who share them. Implicit in the practice of pluralistic Christian politics is a moral realism that connects to older traditions 
of natural law and stands opposed to legal positivism and divine command ethics, by which law and theology, respectively, have sought to construct unitary systems of ethics that could be understood from within in terms of a single principle of legitimacy and could not be challenged from the outside. Marginal Christianity has been, if I may make a fine distinction, subversive rather than resistant. It gets things done rather than waiting for authorization. It prefers to ask for forgiveness rather than permission, to quote a favorite strategic axiom of the marginalized. It helps people accomplish what they are seeking rather than demanding the enactment of its own program. Only later do those who have been helped find that their own expectations have been transformed and that the whole order of social possibilities has been altered.

The philosophers of modern politics are made nervous by this. They applaud the social transformations, when they are complete. John Rawls looked back on the abolitionist movement and the more recent civil rights movement and concluded that they were fully in accord with the requirements of a liberal theory of justice, but he wondered whether the religious language by which they were shaped was fully in accord with the requirements of public reason. He concluded that they were, but the question itself is paradigmatic of the concern for a single public order governed by a common, public language. Those whose politics is descended, however remotely, from the delineation of secular authority by which Luther launched the age of modern politics get nervous when people exhort others to secular action in spiritual terms. They often approve of the results, but they find the method difficult to square with their own philosophy.

The radical Christian witness, by contrast, seems to be perplexed or angered by the strategic successes of marginal Christianity. Living the faith within society is not supposed to work, for theological reasons. So if it appears to work, we may assume that someone has been unfaithful, and the only question that matters is faithfulness, not effectiveness. It is, Stanley Hauerwas tells us, no part of the Christian mission to "make America work."

And of course, he's right about that, if you set the problem in the sixteenthcentury terms that have oddly come to dominate our thinking at the beginning of the twenty-first century. If there is only secular authority or spiritual, only politics or faith, then the Christian choice will lie with faith, and politics will be at best a kind of disagreeable service undertaken on behalf of one's neighbors. But if there is a politics of the workplace, and of the school, and of the museum, alongside the orders of church and state, if there is, in short, a kind of politics for every good that people create and maintain together, then it seems to me that it is very much a part of the Christian mission to make these things work, not just 
as a service to the neighbor, but as a way of understanding our own calling, and finally as part of finding our place in the order of salvation.

The political work that Christians undertake in the public square needs to follow from this understanding of politics in the Christian life. Legislation and litigation are part of what we need to do, because Christian commitment certainly does not exclude participation in the modern politics of law and government. But that type of politics is only one of the forms of politics by which we have learned to work with others to create and maintain the human goods we share. If the politics of the church, the workplace, the cultural community, and, indeed, the politics of the family are not working well, we should not be surprised that the politics associated with government isn't doing so well either. But we should not expect to fix all those other spheres of politics by moving more aggressively to take control of the public square. The future of both Augustine's peace and Aristotle's politics depends rather on working to make sure that all of the institutions that make up modern society are strong and effective and that no one of them is powerful enough to control all the rest. 


\section{Containing Runaway Fear in American Foreign Policy}

by William F. May

William F. May has served as president of the American Academy of Religion and the Society of Christian Ethics. He gave this lecture as the first of the 2009 Stone Lectures, on October 5, in the Main Lounge. The Georgetown University Press will publish the full set of lectures in 2011.

\section{$T_{\text {h }}$}

his cautionary tale recounts the religious apprehensions embedded in American politics, especially in our foreign policy over the last 60 years, as the country dealt anxiously with the successive threats of global tyranny and anarchy. I am a Christian theologian, not a political theorist. Why would I venture on this topic, given that I am not a political leader or a consultant to rulers or an op ed critic of rulers? Machiavelli gives encouragement here. In his preface to the Prince, he asked himself why anyone who was not a prince would dare to give advice to princes. $\mathrm{He}$ compared himself to a landscape painter who views the mountains from a distance that might throw governance in a fresh light. ${ }^{1}$

The scriptures of Israel, although some 2,500 years distant from the current scene, cast light on a world beset by the twin threats of tyranny and anarchy. First Samuel (8:10-18), a narrative about the first rulers of Israel, warns against the fundamental social evil of tyranny. The people hanker for a king to protect them, but the prophet warns that a king will rule arbitrarily and unjustly. The Book of Judges (21:25), recording an earlier time of scattered tribes, flags the opposite social evil of anarchy. "In those days there was no king in Israel; every man did what was right in his own eyes." In one way or another, every society struggles with the twin social evils of tyranny (a form of injustice) and anarchy. These evils pair with two basic, and sometimes contending, social goods: justice

'See Niccolo Machiavelli, in his prefatory letter to Lorenzo the Magnificent, son of Piero de
Medici, The Prince and the Discourses, trans. Luigi Ricci (New York: Random House, 1950), 4.

DOI: $10.3754 / 1937-8386.2009 .30 .10$ 
and order. Every society needs some measure of order to stave off chaos; and it hopes for rulers who will justly exercise their ordering power.

The founders of the United States wrestled with the balance between these two contending social goods or, more pointedly, with the paired social evils, identified twenty-five centuries earlier. As revolutionaries, they opposed, in the first instance, the tyrant King George. However, no less urgently, the founders of the nation, following the failure of their first try, in the Articles of Confederation, also sought to thwart the anarchy that would befall a newly independent nation should each colony simply do what it deemed right in its own eyes.

Thus, the founders devised a constitution that would contain runaway fear. They recognized that an unbounded fear of tyranny would let a society slide into anarchy, hence the need for an energetic and effective federal government. However, a runaway fear of anarchy might produce tyranny, hence the need for a government with built-in checks and balances in the exercise of its power. ${ }^{2}$ Building a just and well-ordered society was no easy task then and is no easy task now. Campaigning against injustice alone, reformers can throw the established order into turmoil. Enforcing solely established order, a dominant leadership can ignore injustices and oppress.

In striking a balance, wise leaders recognize both social goods. No one campaigned more persistently on behalf of those deprived of justice than Martin Luther King Jr. However, his "Letter from Birmingham Jail" detailed a strategy for civil disobedience that also respected order. (King insisted that his followers negotiate with their opponents before engaging in disobedience, undergo a discipline to keep their disobedience nonviolent, disobey only as a last resort and, even then, with the final intent of resuming negotiations.) Meanwhile, his opponents regularly invoked the good of order, but some of them wisely came to realize that a failure to remedy injustice could undercut the stability they prized.

Such progressives and conservatives differ dramatically as to which good they rank primary and which, secondary. However, to the degree that they recognize

\footnotetext{
${ }^{2}$ In one construal, the Constitution was the child of fear. Proponents feared that the failure to adopt the Constitution would mire the colonies in anarchy. Opponents feared that its adoption would create a powerful "central government similar to the one ... [that the colonies] had only recently escaped from." (Bernard Baylin. To Begin the World Anew: The Genius and Ambigulity of the Founders [New York: Vintage Books, 2004], 107). More positively interpreted, the founders conceived the Constitution as a way of containing runaway fear. They recognized that an unbounded fear of tyranny can let a society slide into anarchy, hence the need for an energetic and effective government. A runaway fear of anarchy can produce tyranny, hence the need for a government with built-in restraints.
} 
both social goods, they occupy the "left" and the "right" within a common arena of political discourse. Radicals on the right and left differ from such "centrists" in that they rashly organize themselves solely around the good they prize and against the evil they fear. ${ }^{3}$

\section{Religious Dualism and AnXiety Facing Tyranny}

The evils described in biblical times have followed us into the modern era. After World War II, the leading political anxiety in foreign policy focused on the evil of global tyranny. Most Americans (not only those on the political right) believed that a totalitarian state, the Soviet empire, endangered Europe and eventually the United States. In its extreme form, this anxiety supported an unconditional arms race against a country whose conventional forces exceeded our own. The Soviets mirrored this anxiety in reverse, as they maneuvered against the military and economic colossus of the West. Meanwhile, the very powers of mass destruction each side wielded to oppose the enemy it feared generated its own fears. The opposing superpowers, edgy with nuclear weapons, could — either by accident, runaway fear, or malice aforethought—destroy one another.

Religiously put, a dualist vision drove extremists East and West. ${ }^{4}$ The ancient dualists reduced all distinctions in the universe to the cosmic struggle between two rival powers: the kingdom of God pitted against the kingdom of Satan, good versus evil, light against darkness, spirit opposed to matter. Modern dualists have embedded this cosmic struggle in the arena of politics. After World War II, dualists identified the forces of righteousness with the capitalist West and the legions of Satan with the communist East. The Communists returned the favor by reversing the players in the mythology: the Soviets would usher in the New Jerusalem by vanquishing Western economic imperialism.

In either case, the common term in the Manichaean story line is "kingdom." Each side perceives its enemy as hierarchically organized. In its revolutionary activity, the Communist Party did not tolerate the disorderly dabbling of adventurers or badly timed spontaneous uprisings. Correspondingly, the West organized

\footnotetext{
${ }^{3}$ Centrists on the right and left also hold to their own differing definitions of the goods they rank first and second. For example, conservatives committed to law and order tend to confine economic justice to the enforcement of contracts, despite large inequalities in the relative power of the parties entering into contracts. Meanwhile, liberals committed to justice tend to define the social good of order by arrangements in the making rather than by the root system of past ties.
}

${ }^{4}$ See William F. May, "Manichaeism in American Politics," Christianity and Crisis 26, 7 (1966), 85-89. 
itself hierarchically, both militarily and in the setting of large corporations. The philosopher Alasdair MacIntyre highlighted this organizational feature of the modern conflict between capitalism and communism by identifying Max Weber, not Adam Smith or Karl Marx, as the ruling theoretician of the modern world. While opposed to each other in ideological content, the West and East have mimicked each other in their dominant organizational form-the bureaucracyof which Max Weber was the great cartographer.

In their appeal to portions of the electorate in America, dualists have often invoked the language of biblical monotheism-good versus evil, God versus Satan. However, dualism and monotheism differ. Monotheists affirm God to be one-not two. Evil is real but not ultimate. Dualists tend to act as if the devil is coequal to God. They obsessively orient their lives and policies around the ultimate foe. Any limits on their anxieties and rage seem unwarranted and unjustified. Furthermore, by separating humans into two organized, warring camps of the righteous and the unrighteous, dualists dismiss the Pauline warning that all fall short of the glory of God. They are metaphysical separatists. They abhor especially the confusion, commingling and tainting of good with evil. ${ }^{5}$ They prefer the clarity of military contest (pointed toward a final rollback and victory) to political compromise.

\section{The Containment of Tyranny}

Under President Truman, the United States developed a response to the threat of the Soviets, not by acting on the dualist script from the political right but by following-irregularly-the more moderate policies of deterrence and containment (and the rebuilding of Europe) spearheaded by Secretary of State George C. Marshall and Under Secretary Dean Acheson. They drew heavily on proposals developed by George F. Kennan, the chargés d'affaires of the U.S. mission in the Soviet Union and at length the head of the Policy Planning Staff in the State Department. Kennan argued for the diplomatic and military containment of the expansionist tendencies of America's former ally. Containment required recognizing the evil of tyranny for what it is but at the same time putting it in the

\footnotetext{
${ }^{5}$ The ancient Manichaean myth inspired a theology of history that marked off cosmic conflict in three stages: (1) an original state of uneasy separation between the two rival powers, followed by (2) an aggravated period of their confusion and commingling, that could be resolved only by (3) a final state of metaphysical apartheid in which the kingdom of righteousness will expel its rival and, in open military contest, shear it of its aggressive power and, in this sense, achieve a final victory. Clearly, the second stage marks the worst state of affairs. Dualists want the lines clearly drawn. Negotiating compromises demeans and taints the purity of the righteous.
} 
lower case. Militarily, it excluded both appeasing and seeking supremacy over the Soviets.

Less noticed, Kennan emphasized that containing the Soviets required that the United States contain itself and its own insecurities. The United States should not view Russia through the distortions of fear, as though our enemy were indelibly powerful and evil. An anxious overreaction to Soviet tyranny was unjustified and could be self-defeating. We would succeed merely in draining American resources needed for long-term competition and arouse animosities against us elsewhere. Kennan reminded us that we see "as if through a glass darkly." We should not automatically assume that Russia will remain inalterably what it is, absent rescue by American military misadventures. Kennan's hope rested on something more substantial than the vague feeling that maybe something better would turn up later. An overextended imperial Russia, he believed, could not sustain itself indeterminately into the future.

Kennan also believed that an anxious overreaction to the Soviets would be selfdeforming for the United States. It would alter the American Republic into a hypertensive empire. Containment of Russia required our own self-containment. Long-term competition required that America remain firmly and patiently what it is, a Republic. "The most important influence that the United States can bring to bear upon internal developments in Russia will continue to be the influence of example; the influence of what it is, and not only what it is to others but what it is to itself." The United States should refrain from bossy report card keeping and moralizing in its dealings with the Soviets and other nations. Selfcontainment calls for a brace of continuing virtues: firmness, patience, humility, self-confidence, and hope. ${ }^{7}$

${ }^{6}$ George F. Kennan, "America and the Russian Future," Foreign Affairs, xxix, 3 (April, 1951), found in George F. Kennan, American Diplomacy, 1900-1950 (New York: New Modern Library, 1951), 126. Still earlier, Kennan wrote that a self-confident America will give "the impression of coping successfully with the problems of its internal life." See George F. Kennan, "The Sources of Soviet Conduct," Foreign Affairs, xxv, 4 (July, 1947), found in American Diplomacy, 105. Kennan did not propose negotiating with the Stalinists, but not for the categorical reason that dualists might have advanced (against negotiating with an evil power). Rather, Kennan believed that the Stalinists, at the time, would (and could) not negotiate with the United States because their purchase on power within Russia depended on defining the United States as their absolute enemy. The moment for negotiations had not yet arrived.

${ }^{7}$ Kennan did not at that time recognize the long-range necessity for the virtue of temperance in restraining American appetites in economic policies. While Eurocentric (he supported the Marshall Plan for the reconstruction of Europe as serving our vital national interests), he did not yet recognize the long-range problems of global turmoil we stored up for ourselves as a nation controlling $50 \%$ of the world's wealth with only $6.5 \%$ of the world's population. 
Forty years later, Kennan's message of patience and hope seemed vindicated by the dramatic events of 1989. In his single-volume sweep of the Cold War, ${ }^{8}$ the historian John Lewis Gaddis bracketed the period with an opening chapter on the "Return of Fear" (the insecurities besetting the victors at the end of World War II); and he closed with a final chapter on the "Triumph of Hope" (as the imperial Soviet Union devolved into the diminished Russia of 1989). Clearly, the Cold War had not been entirely cold. Wars were fought in East Asia and Southeast Asia, and small nations were crushed. However, no nuclear weapons were dropped, and the great powers had not directly engaged in battle. Kennan, he believed, was vindicated. In fact, however, the story did not end simply in a triumph of hope. A second and differing wave of anxiety overran the major players in the later stages of the Cold War and dampened any disposition to celebrate unalloyed hope in either the East or the West: the threat of anarchy.

\section{Anarchy on the Current Scene}

The Soviets experienced first, and most traumatically, a shift in their anxieties toward anarchy. Although glasnost and perestroika opened up the Soviet Empire to the outside world, the society quickly spun out of control, as client states and regions within the Soviets broke off from the Empire. The government suffered a chronic hemorrhaging of its resources in Afghanistan and, a decade later, in Chechnya. Authorities sold off public assets of the nation at fire sale prices, creating economic warlords, who ran their fiefdoms as they pleased. The earlier meltdown at Chernobyl wasted an entire region and came to symbolize the plight of a society that had lost the ability to contain explosive powers within.

At length, a similar but subtler shift in political anxieties appeared in the West. The invasion of Kuwait threatened the stability of a world order that depended upon both oil and the territorial integrity of nation states; and a rash of troubles broke out in the 1990s. "Failed nations" became a category in political thought. Cumulatively, the disintegration of the Balkans, the implosions in Africa, the flare-ups between the Arabs and Israelis, and, most spectacularly, on a clear, blue, telegenic day called $9 / 11$, the symbols of prevailing power for the United States, the "commanding heights," as it were, fell to the ground, ground zero. Thereafter, a second religious vision offered a different narrative account of the political scene, not order versus malevolent order but order versus chaos, the political term for which is anarchy.

\footnotetext{
${ }^{8}$ John Lewis Gaddis, The Cold War: A New History (New York: Penguin Press, 2005).
} 


\section{The Babylonian CReation Myth}

Since the 1990s, we have been moving from the basic story line of Manichaean dualism to a narrative that traces back to dualist scriptures older than the book of Genesis. The Babylonian creation myth gives an account of a cosmic struggle between two rival gods but, this time, not order versus malevolent order but order against chaos. Marduk, a kind of sheriff deity, the enforcer of law and order, battles against Tiamat, a formless monster issuing from turbulent waters, the symbol of primordial chaos. Marduk slays Tiamat and fashions the world out of Tiamat's dismembered body (and humankind out of the blood of Tiamat's son, who contrived the uprising against order). Thus, the world that we know and the creatures we are participate, at one and the same time, in order and chaos. To complicate the picture, Marduk has a taste for violence. He not only slays but dismembers Tiamat's body; he is given to a somewhat enthusiastic overkill: "There lie hidden in the dark depths of his soul both violence and wildness." The myth reminds us that a society threatened with disruption and chaos may suspend its self-restraint and rally around its police and militia for the sake of "law and order." It may even tolerate an outcropping of lawlessness in its law enforcers, permitting them a kind of frenzy and ecstasy, if you will, in protecting the compound of the law. One tribe referred to its lawless defenders as "the king's knives." The king lets them stand outside of the law while making their stand for the law. Thus, the contest does not offer a perfectly pure conflict of opposites. While, at first glance, the struggle seems a clear-cut battle between rival symbols-Marduk versus Tiamat, law and order versus chaos - the dragon's tail may show beneath the sheriff's uniform.

The Babylonian creation myth expresses a dread of chaos through the image of floods that engulf and overwhelm all structures and forms. The periodic flooding of the two great rivers of Mesopotamia may have inspired the ancient myth. Tiamat roils in the flood waters. ${ }^{10}$ In our time, we experienced the shudder of chaos in Babylon itself and on our own Gulf Shores in Katrina. ${ }^{11}$

\footnotetext{
${ }^{9}$ Thorkild Jacobsen in Before Philosophy (Middlesex: Harmondsworth, 1951), 139.

${ }^{10}$ Modern literature varyingly associates water with the boundaryless, the dangerously chaotic. Herman Melville distinguishes Starbuck, the landlubber, who cherishes and honors the settled boundaries and institutions of terra firma, from Ahab, the monomaniacal sea captain who forsakes all that is temperately human to pursue the whale. William Faulkner gives an account in Wild Palms of prisoners released from the restraints of jail to fight against a flood that destroys everything before it. The rampaging Mississippi waters expose more than a seasonal eruption; they signal the primordial chaos that churns beneath all things.

${ }^{11}$ While the boundless and potentially destructive character of water supplies a powerful and recurrent image of chaos, two other of the four basic elements supply us with yet further images: fire (which incinerates forms), and thin air (into which forms vanish). The destruction of the twin towers on $9 / 11$ captures both. Meanwhile, the admixture of water with the fourth element of earth (the mud of a quagmire and the festering of a swamp) provide two further images that figure in political rhetoric and strategies today.
} 


\section{TERRORISM AND THE THREAT OF ANARCHY}

Disarray in distant places did not seize the United States with anxiety as much as that singularly violent event that seemed to split time in two-September 11. The terrorists aimed at the supreme symbols of the "new world order" (the first President Bush's phrase for shaping the future after the breakup of the Soviet Union). The first target, the World Trade Center, symbolized (and claimed by name) an economic ascendancy over the world located in New York City. The second target, the Pentagon, symbolized the very heart of the modern West's account of the origin and justification for the state. From the seventeenth century forward, the West, following social contract theory, traced the origins of the state, not to a supreme good-God or the sacrifice of a founding hero-but to the protection the state provides against a supreme evil-the evils of theft, invasion, and violent death. We give to the state a monopoly over the power of death, authorizing its police and military powers; in exchange, the government assures us that, when we go to sleep, we will not be robbed or murdered in the night. That's the political deal. People fear death and so they enter into a contract, conveying to the state the awesome power to kill in order that they may not be killed. ${ }^{12}$

However, the terrorist event proclaims on television that the state cannot protect you against a violent death. The terrorist breaks the state's monopoly over violence, not simply by his readiness to kill but by his willingness to die. With his body wrapped in explosives, he stands outside of ordinary fear and therefore the power of the state. He is an ecstatic in the literal sense of that word. Meanwhile, the rest of us, who still fear death, have lost our protector. Decades ago, when the Irish conflict erupted in the bombing of various pubs in London, a member of parliament said, "From now on, every man, his own magistrate." Scotland Yard cannot protect you. Random violence suffuses the everyday with uncertainty and therefore with the prospect of the anarchic.

\footnotetext{
${ }^{12}$ The fear of death crowds us together and establishes the state according to the Hobbesian account of origins. (See Thomas Hobbes, Leviathan [Bristol: Thoemmes], chap. xiii.) While the later social contract theorist John Locke works in pastel colors, he does not differ from Hobbes in his understanding of the origins of the state in a negative. Men compact together and establish the state not because they want a common good but because of the evils that would beset them had they remained in a state of nature. Life and property and freedom would be very "unsafe and insecure" and "full of fears and continual dangers" without the protection of the government. (See John Locke, The Second Treatise of Civil Government [Adelaide: University of Adelaide Library, 2008], chap. IX, par. 123). Locke differs from Hobbes not on the account of the fear that inspires individuals to enter into the contract but rather on the rights that citizens retain to dissolve it. Citizens may dissolve or withdraw from the contract, if and as the sovereign should fail to keep his side of the bargain, either by failing to provide basic protection or by exercising additional, arbitrary powers.
} 
In their choice of means - the commercial airplane-the terrorists also denied to Americans the comfort that they are safe at a distance. Anybody can be on an airplane. There is no longer any security in obscurity or anonymity. Television moreover guarantees that the event, caught on camera, will annihilate distance and reverberate liturgically over and over again in the country.

The attacks of terrorists were ecstatic in the further sense that they did not seem to fit into the sequential world of political means and ends. Why did they do it? To what purpose? What did they hope to accomplish by a propaganda of deed? Their actions seemed only to galvanize hatred and fear.

In the past, critics tended to interpret terrorist movements simply as a type of political strategy and found them wanting. They were counterproductive and selfdestructive. As John Hume, a "Bogside" Catholic member of Parliament, once put it, "The Provos bombed themselves to the conference table, and then they bombed themselves away again." 13 So interpreted, terrorist action breaks up into what Hannah Arendt called the irrational. The connections between means and end and between agent, victim, and intended social consequence so attenuate that the action juts out as a surd. It becomes a politically impenetrable end in itself. ${ }^{14}$

\footnotetext{
${ }^{13}$ Curt Prendergast, "Northern Ireland: Reflections on Agony and Hope, Time Magazine, January 29, 1973.

${ }^{14}$ In the setting of nineteenth-century nihilism and anarchism, terrorism cannot be wholly understood as a political strategy. It also reflects a kind of religious ecstasy. I do not intend by introducing that phrase in this footnote to link terrorism to the scriptures of Israel, the Christian Church, or the Koran. Whatever the specifics of their religious traditions, terrorist leaders have sometimes depended for their foot soldiers upon ecstatics who stand outside the ordinary, practical world of means and ends. They enact a deed that has become an end in itself. Their action transcends the world of politics and, indeed, this world altogether. Formally considered, the concept of an action that is an end in itself puts us rather close to the religious meaning of celebration. As Josef Pieper pointed out, "To celebrate a festival means to do something which is in no way tied up to other goals; it has been removed from all 'so that' and 'in order to.' True festivity cannot be imagined as residing anywhere but in the realm of activity that is meaningful in itself' (In Tune with the World: $A$ Theory of Festivity, New York: Harcourt, Brace and Wonk, 1965, 7). In the case of terrorism, of course, we are talking about a festival of death, a celebration that has its own priest and victim and that carries with it the likely risk that the attacker himself will become one of the victims. Today, the rest of us become awed witnesses to this liturgical action through the medium of the media. Andre Malraux, in his novel Man's Fate, drawing perhaps on the nihilists and anarchists and also on the romantics of the nineteenth century, captures better than anyone else this religious ecstatic encounter with death. (See pp. 9-19, 192-96, and 246-49 in the Random House, Modern Library Edition, 1934.) Malraux's account of the transfiguring encounter with death in the person of Che'en materializes in the nineteenth- and twentieth-century nonfiction literature about terrorists. The Algerian F.L.N. (in its paper Al Mondjahid, August 20, 1957) observes, "As soon as the terrorist accepts the mission, death enters his soul. Henceforth he has a rendezvous with death." (See Roland Gaucher, The Terrorists, translated by Paula Spurlin [London: Secker and Warburg, 1968], 201.) "In the Catechism of the Revolutionist," variously attributed to Nechaev and Bakunin, the phrase, "The revolutionist is a doomed man," is a repeated litany. "He must be ready to die at any moment." See Max Nomad, Apostles of Revolution [Boston: Little Brown, 1938], 228).
} 
(The ecstatic event may have transcended political strategy at the level of means and ends but reintroduced politics at another level. Although it breaks with the conventional notion of a politics of effectiveness that leads to the conference table, it offers what Max Weber and John Yoder, in other settings, have called a politics of witness. The endlessly repeated episodes of violence thereafter seemed to signal the passing of the apparently fixed world and to herald something else aborning. Its politics of witness aspired to return to a ground zero.)

In response, any government seeking to stop terrorism also seems to slide into the irrational and counterproductive. Its actions lose connection to the causal nexus of means and ends. Overreaction is difficult to curtail, even though it solves no problem. By discharging a boundless resentment, it yields only an immediate satisfaction. It offers enticingly an immediate end in itself but no future.

In the first stage of the American reaction to the attack of $9 / 11$, American leaders seemed aware of the problem of shaping the future. The then president George W. Bush talked about the importance of humility and the fair treatment of Muslims; he reversed his earlier dismissive campaign talk in 2000 against nation-building and recognized the necessity of reconstruction in Afghanistan following the overthrow of the Taliban government.

In the course of 2002, however, leaders shifted attention (and funding) from Afghanistan to the prospect of a preventive strike against Iraq for reasons and purposes that kept changing and expanding. Critics warned that in going to war against Iraq, the United States risked becoming the source of destabilizing power in the Middle East and the world at large and also conflicted in its own interior life. In dismay, General Zinni complained that, in fighting Iraq, America struck a beehive with a baseball bat. Therewith, we handed Osama bin Laden a great gift. An increasingly marginalized movement managed to expose, to an aroused Muslim and a baffled Western world, the preeminent power on earth in its relative powerlessness. America's exercise of power seemed self-defeating.

The religious story line embedded in the administration's response to $9 / 11$ was puzzling. The Bush administration declared that the attack changed the world; and yet the government failed to respond to the distinctive threat of anarchy that terrorism posed. Its rhetoric and policies still conformed to a pre-9/11 mindset. It relied on the old diagnostic category of order pitted against malevolent political order rather than order versus chaos. It viewed its enemy as the old recognizable nation-state, even though, as it later came to realize, its terrorist opponents were politically amorphous and transnational; and the nation of Iraq supplied all the combustible human materials for an eructing chaos. The government quickly 
turned its guns on Iraq after invading Afghanistan and identified three states as constituting an "axis of evil," a phrase that attempted to carry forward the old organizing principle for fighting World War II.

At first, the administration campaigned against Al Qaeda itself as if it were hierarchically organized. It used that most convenient symbol of hierarchy-a deck of cards - to identify and rank each of Al Qaeda's leaders and display to the media its progress in defeating the movement. However, Osama bin Laden and al-Zawahiri did not control terrorism like the chair of the board and CEO of General Motors. Terrorist groups operated more like do-it-yourself and decentralized franchises than a bureaucracy that might be defeated from the top down. Though unitary in spirit, the terrorists did not depend upon unitary control.

Osama bin Laden did not aspire to take territorial control of a government like the revolutionaries or expansionist empires of the past. The old strategic categories of "falling dominos" or "government takeovers" did not quite apply to the struggles in the Middle East. Instead, terrorists, in Iraq and elsewhere, aimed at turning the strengths of the highly interdependent global order of the West against itself. John Robb in Brave New War has called this aspect of its basic strategy "systems disruption." 15 Along with inspiring random attacks on people, the strategy inspired selective attacks on the global system in its vulnerabilities - its pipelines, airlines, utilities, electricity supply lines, roads, and communications systems. Meanwhile, the misguided reactions of the United States and other governments produced a phenomenal rate of return for terrorists in their conduct of a poor man's war. Al Qaeda, while investing approximately half a million dollars in the 9/11 attack, provoked a response from the United States climbing toward a trillion dollars by 2008 . That figure paled before the immeasurable costs to the United States alone in soldiers killed and injured and damage done to its power position in the world. The protracted disarray in Iraq altered the conventional metrics of American military and political power.

\section{CONTAININg THE Threat OF TERRORISM}

A foreign policy that would contain the long-term threat of chaos once again calls for containment-a policy that falls between supremacy and appeasement. Yale

\footnotetext{
${ }^{15}$ For this paragraph, see chap. 5 of John Robb's Brave New War: The Next Stage of Terrorism and the End of Globalization (Hoboken: John Wiley \& Sons, 2007). Robb has little confidence in the nation-state as a provider of security and looks to local, decentralized, privatized, and crossconnected communities to provide security in the future. His visionary book reminds one of Simone Weil's proposals for the future of France following World War II: decentralized and local. However, Robb's analysis lacks the more organic, communitarian spirit of Weil's vision in The Need for Roots.
} 
political scientist Ian Shapiro put it succinctly, "The idea behind containment is to refuse to be bullied while at the same time declining to become a bully."16

Critics of containment have objected that terrorists have changed the nature of the game for the nation-state. Conventional tactics will no longer work. The political irrationality of terrorism demolishes the traditional diplomatic ploys of restraining bullies with disincentives and incentives. How can you contain or deter terrorists with the prospect of their death when they have already handed themselves over to martyrdom?

Shapiro responds to this challenge by distinguishing between three groups: the attackers, their leaders, and the leaders of enabling states. ${ }^{17}$ Although the attackers (whom I have described as ecstatic) may not be eliminable and all their attacks, deterrable, they are containable. Terrorists do not attack without aid. Even if individual terrorists operate at a level indifferent to death, their leaders and enabling institutions and states will be susceptible to incentives and disincentives for the sake of the survival of their cause or their community.

What are the long-term prospects for containment today? In assessing Islam, an argument can be made that the prospects are at least as good for a favorable outcome today as George Kennan could reasonably hope for in the contest with the Soviets. Admittedly, terrorists draw on some passages in the Koran to justify their cause. However, the diversity within the sacred scriptures and traditions of Islam gives at least as much ground for hope in the emergence of moderating influences in Islam as the writings of Marx, Lenin, and Stalin justified hope for changes in the Soviets and worldwide communism.

However, even more intensively in this case, the United States must recognize that containment calls for self-containment. The nation needs a better sense of what power is and what the role of the country is in its exercise. It requires that the nation not yield to runaway fear and distort itself as a republic or indulge in an imperial presidency or in the fantasies of the imperial self.

\section{The Conception And Exercise of Power}

Despite its floundering in the Middle East, the United States still wields preeminent power in the world today-both hard power and soft. Moralist Albert

\footnotetext{
${ }^{16}$ Ian Shapiro, Containment: Rebuilding a Strategv against Global Terror (Princeton: Princeton University Press, 2007), 37.

${ }^{17}$ Ibid., 76-89.
} 
Camus wryly distinguished between the two kinds of power by observing that power includes not only the force of a tornado but sap in the tree. The violence of shock and awe is one thing; the surge of organic growth, another.

Recently and less vividly, Joseph S. Nye argued that the hard power of sticks and carrots (military and economic) does not of itself let a country such as the United States sustain its influence or command. The country depends also upon its soft power, which often operates indirectly: the respect of others for its laws and its law-abidingness, the attractiveness of its educational and cultural institutions, its support for international institutions and enduring alliances, and, for better or for worse, the worldwide addictiveness of its technologies and the penetration of its mass media. ${ }^{18}$ (Nye's distinction between hard and soft power does not hold in some important cases. Ordinarily, economic power beats down like sticks on poor people and nations that have few carrots and little or no bargaining power in dealing with the mighty. However, money can also fertilize the fields of poor nations under more forgiving conditions of loans and investments. Ordinarily, education functions as soft power; however, sometimes it imposes itself on a minority like forced feeding. It gags rather than nourishes; and it produces in a minority what Franz Fanon once called a "spiritual lockjaw.")

Ascendant power depends upon a material base from below and a kind of legitimacy from above or from its surround. In addition to much else, successive "empires" of the West have depended upon the power of wind and water (the Dutch), steam (the British), and oil (the Americans) to drive them militarily and economically. ${ }^{19}$ But they have also depended, in varying degrees, upon a kind of legitimacy bestowed upon them by the benefits of protection derived from their hard power and by the communicability of their economic and soft powers. ${ }^{20}$ Ascendant powers fail when they have depleted (or failed to adapt or replace) their outmatched material base and when their economic and soft powers seem un-shareable or undesirable.

In a world in which no monopoly on the use of force can provide a nation with total security-not even the United States - how should the country conceive its exercise of power in relationship to others? First over others? First apart from others? Or first among equals? Before the election of George Bush in 2000, the neoconservatives strongly backed the doctrine of first over others. They argued

\footnotetext{
${ }^{18}$ Nye, The Paradox of Power, 4-12.

${ }^{19}$ Kevin Phillips, American Theocracy (New York: Viking, 2006), chaps. 1-3.

${ }^{20}$ Amy Chua, for example, sees tolerance as an important key to legitimacy (and longevity) in her comparative study of empires, Day of Empire: How Hyperpowers Rise to Global Dominance and Why They Fall (New York: Doubleday, 2007).
} 
that the United States, as the sole superpower, occupying a "position unmatched since Rome," ${ }^{21}$ should not act like a "reluctant sheriff." It should be ready to project power and "conceive of itself as a European power, an Asian power, a Middle Eastern power, and of course, a Western Hemispherean power."22 Thereby the United States would fulfill its role in sustaining a benevolent global hegemony in a world that has already been transformed economically "in America's image." 23

Until recently, when Americans looked in the mirror, they did not see an imperial face. They associated the word "empire" with a permanent, territorial occupation of other countries. While they would be surprised to know that at least 725 American military bases existed outside the country, ${ }^{24}$ they took pride in the United States of America as a nation without ambitions to plant the American flag elsewhere. Meanwhile, decisions made in American boardrooms could alter foreign landscapes, for good or for ill, far more decisively than "Tommies" showing the British flag in nineteenth-century India.

The Bush administration acted on the doctrine of first over others, both before and after $9 / 11$. The government's defense policy called for a military prowess exceeding that of all other nations combined, and it loosened the restraints on using that power to go to war. The administration appeared before the United Nations in the run-up to the Iraq War only reluctantly and tactically, and it dismissed the warnings of its long-term partners in those alliances as offering the counsel of "old Europe." It replaced the stricter standard of a preemptive war (which allowed a nation to attack only in the case of an imminent threat) with the looser standard of a preventive war (which justified attack in the case of a more vaguely defined "gathering threat"). In effect, it gave leaders the widest possible latitude in taking the country to war and loosened restraints on how they might conduct it. Leaders in the Justice Department passed off some provisions of the Geneva Convention on the abusive treatment of prisoners and torture as "quaint" and "obsolete," and the Defense Department and the CIA acted accordingly.

The old isolationist doctrine of first apart from others appealed to Americans in the 1930s and reappeared on the libertarian Right and the re-emergent Left in their reaction to the long-term policies of George W. Bush and, more recently, to

\footnotetext{
${ }^{21}$ Robert Keegan and William Kristol, eds., Present Dangers: Crisis and Opportunity in American Foreign and Defense Policy (San Francisco: Encounter Books, 2000), 5.

${ }^{22}$ Ibid., $15,16$.

${ }^{23}$ Ibid., 5.

${ }^{24}$ Chalmers Johnson, The Sorrows of Empire: Militarism, Secrecy, and the End of the Republic (New York: Henry Holt and Company, 2004), 4.
} 
Barack Obama's proposed short-term military commitment to Afghanistan. In a sense, a common thread underlies policies of either domination or withdrawal. By simply withdrawing from the world, the United States would repeat on a global scale a strategy that has appealed to some of the privileged within the country - the security of being a gated community. But withdrawal is no longer an option for a country that has undercut-through its transportation, economic, and communication systems, to say nothing of its addiction to oil-its capacity to survive alone. The path of isolationism is also dubious morally. It neither repairs the damages wrought by American hegemony nor discharges the responsibilities that fall upon a nation of ranking power.

The third self-conception, first among equals, would recognize America's current, preeminent power as a fact of life and attempt to lead rather than to dominate or withdraw from the world. In general direction, an American foreign policy that leads, rather than dominates, other nations should be multilateral rather than unilateral. It should repair and strengthen its enduring alliances; it should heal, as best it can, botched relations in the Middle East, set the course for its relations to the emergent powers of China and India, and mend its frayed relations to international bodies, such as NATO and the United Nations. It should attend seriously to global warming and encourage the development of new, sustainable resources and energies on which human life and flourishing will depend on an overburdened planet. It will also need to respond to the seething expectations that roil modern life, often issuing from the poor, the politically voiceless, and the culturally bereft, which neither passive reliance on the mechanism of globalization nor the all-consuming war on terrorism adequately address.

It is not my purpose in this essay to examine the important particulars of this third kind of role in foreign policy. I am concerned chiefly to explore theologically how our anxious response to the external threats of terrorism and tyranny has tempted us to favor the role of dominating rather than leading other nations. No single election retires such issues. Are we a republic or an empire? Does the president operate within a system of checks and balances? Or do the exigencies of our current plight demand a vastly expanded presidential role in foreign policy and domestic security? What view of the citizen, imperial or civic, underlies these debates? Because recent leaders have used some of the familiar language of monotheism to appeal to parts of the electorate in gaining support for their imperial understanding of the nation's mission, the president's authority, and the citizen's identity, comments are in order on these issues as Christian thought bears on them. 


\section{Monotheism, Dualism, and National Self-Conception}

Monotheistic belief calls for a basic conception of the nation and a foreign policy at once humbler and more confident than the religious outlook that has shaped the recently prevailing conception of America's role. Although he is not a theologian, Zbigniew Brzezynski touches on the larger scheme of things. There are no immortal nations or empires. "America's global dominance" in the course of time "will fade." ${ }^{25}$ That fact should be religiously bearable on the grounds that God, not America, is the beginning and end of all things. However, this powerful but mortal country and its institutions can also leave a legacy in the course of its continuance under wise leadership. Wisdom, however, requires keeping the country's fears and anxieties under control, lest it distort its fundamental identity as a nation.

Biblical realism addresses the issue of fear and anxiety. Monotheism affirms that the evils of both injustice and chaos are real but not ultimate. We misinterpret and undervalue our lives, our politics, and much else when we split the world asunder into two gods, whether order versus malevolent order or order versus chaos. Dualists of either sort tend to be religiously grim and therefore, in their apprehensiveness, reach for total control and power. Their language poaches on the messianic. He who is not with us is against us. This mindset speeds the collapse of politics and diplomacy. A foreign policy of runaway fear drives for absolute security, which, in turn, justifies the unilateral presumption to empire. Meanwhile, imperialists in their isolation are prey to the fear that every challenge, every limit, undercuts their control. Thus, their insecurity spreads unabated. Presumption and anxiety feed one another; and politics starves. Politics depends upon entrusting and trust-building gestures, which the anxious imperialist, who insists on absolute control, cannot extend. In his isolation, he cannot suffer any limits on his power.

In a culture of fear, leaders and their subordinates, charged with security, are tempted to press beyond the previously accepted limits of the law. Jack Goldsmith, for example, the conservative head of the Office of Legal Counsel in the Justice Department from 2003 to 2004, puzzled over the reasons for the poor judgment of his predecessors in drafting the August 1,2002, and March 14, 2003, opinions of the Department that prepared the way for Abu Ghraib and the torture and abuse of "Alien Unlawful Inhabitants." He surmised, "The main explanation is fear." ${ }^{\prime 26}$ When Goldsmith reported to Alberto Gonzales, then the

\footnotetext{
${ }^{25}$ Zbigniew Brzezinski, The Choice: Global Dominion or Global Leadership (New York: Basic Books, 2004), 213.

${ }^{26}$ Jack Goldsmith, The Terror Presidency: Law and Judgment Inside the Bush Administration (New York: W.W. Norton \& Company, 2007), 165.
} 
president's attorney, and to David Addington, then the vice president's assistant and later his chief of staff, that he could not justify legally an "important terrorist counter-measure," Addington responded in disgust, "If you rule that way, the blood of a hundred thousand people will be on your hands."27

In this heated atmosphere, Vice President Cheney reportedly argued that "If there is a one percent chance that Pakistani scientists are helping Al Qaeda build or develop a nuclear weapon, we have to treat it as a certainty in terms of our response. ..." Cheney expanded, "It's not about our analysis, or finding a preponderance of evidence. ... It's about our response."'28 This doctrine justified a policy based on a remote and abstract possibility, not a perceived reality. As the world's only superpower, the neoconservatives urged, the United States should concentrate on creating new realities rather than tether itself to the Realpolitik of old Europe. It need not feel obliged to consider all factors, influences, and consequences of action as it recreated the Middle East and reconfigured the world.

\section{THE ILLUSIONS OF EMPIRE}

In addition to its supply of hard and soft power, a nation needs to respect the importance of what has been recently dubbed "smart power." The currently popular phrase implies a reaction to at least two aggressive ways of being dumb: unleashing power under the illusion of either omniscience or omnipotence. In an aphorism reminiscent of theologian Reinhold Niebuhr, Arthur Schlesinger Jr. once observed, "History is the best antidote to illusions of omnipotence and omniscience." 29 The earlier cold war realists, in my judgment, suffered primarily from the illusion of omniscience. Nixon and Kissinger prided themselves on being experts in how the world works. Kissinger warned: "We should not destroy what is possible by forcing events beyond what the circumstances will allow. ${ }^{130}$ Statecraft would triumph through their craftiness.

\footnotetext{
${ }^{27}$ Ibid., 71. As head of the CIA, George Tenet also wrote, "[You] simply could not sit where I did and read what passed across my desk ... and be anything but scared to death about what it portended." Ibid., 72. In a similar vein, former Deputy Attorney General Jim Comey averred, "Reading about plans for chemical and biological and nuclear attacks ... causes you to imagine a threat so severe that it becomes an obsession."

${ }^{28}$ Ron Suskind, The One Percent Doctrine; Deep Inside America's Pursuit of Its Enemies Since 9/11 (New York: Simon \& Schuster, 2006), 62. Vice President Cheney offered this view, late November 2001, in a meeting with Condoleeza Rice, George Tenet, and a Tenet briefer in attendance. One or both of the latter two must have been Suskind's source.

${ }^{29}$ Robert Dallek, Nixon and Kissinger: Partners in Power (New York: Harper Collins Publishers, 2007), 613-23.
}

${ }^{30}$ Ibid., 297. 
In contrast, the neoconservatives suffered from the illusion of omnipotence. They believed that the United States had the power to create the circumstances in Iraq and elsewhere, to which other nations would have to adjust. The government did not need to know the religious and cultural intricacies of the world we were replacing. In a sense, history did not matter. Democracy would follow swiftly upon overthrowing the tyrant. The whole world, Iraq not excepted, thirsted for freedom, defined as we define it.

Classical conservative thinkers, as early as Edmund Burke, have countered: history does matter. Democracy has to be grown, not simply imposed. As it takes hold, it resembles less the tornado than sap in the tree. We need not agree with every detail of Zbigniew Brzezinski's analysis in Second Chance to appreciate the importance of organic growth to a democracy.

Democracy historically has emerged through a prolonged process of enhancement of human rights, first from the economic, and then to the political ... that process in turn entails the progressive appearance of the rule of law, and the gradual imposition of legal and constitutional rules over the structure of power. ${ }^{31}$

History warns against the illusion of remaking the world in our own image. ${ }^{32}$

\section{Curbing the Imperial Presidency}

Recovering our national identity in foreign policy depends upon rebalancing the several branches of government within the United States. Those who defined America's role as first over others on the global stage pushed (while

\footnotetext{
${ }^{31}$ Zbigniew Brzezinski, Second Chance: Three Presidents and the Crisis of American Superpower (New York: Basic Books, 2007), 155. The neoconservatives have countered this classical conservative warning about the difficulties faced in imposing democracy on other countries by pointing to the successful transplant in West Germany and Japan after World War II. Allied successes there prove that outside interventions do not inevitably fail. However, critics have distinguished the cases. Iraq lacked the basic coherence and common memories on which the other two countries could build.

${ }^{32}$ The difficulties of recasting the world in our own image came home dramatically in the public television report on "America at a Crossroad" (2007). The host, Robert MacNeil, showed a clip of an American motivational trainer trying to drum into Iraq's troops the President's message of freedom. The trainer got them to shout over and over again in unison, "Freedom! Freedom! Freedom !" He resembled a high school football coach juicing up his players before sending them out into the red zone of the gridiron, all to no avail. The opposite of tyranny for the Iraqis (as for the Israelites of 1 Samuel) is not freedom but justice. The religious right in Iraq has preached obedience, not freedom, and theocracy, not democracy. Liberty leads to chaos, not justice. Gagging them with our word "freedom" is not likely to leave a democracy blooming in the desert or on the streets of Baghdad.
} 
they were in office) for a presidency that exerted dominant power over the other branches of government and over the press on the domestic scene. Vice President Cheney believed for decades that the nation suffered through a series of events a weakening of the president's power at the hands of Congress, the courts, and the press. The Freedom of Information Act and leaks to the press ensnared the Reagan presidency in the Iran-Contra affair. In addition, the appointment of independent councils to investigate and perhaps indict executive officers and staff, the limitations on surveillance advanced by the Church Committee of the U.S. Senate, and other restraints and distractions combined to diminish presidential power in deference to activist judges and 535 legislators and to the 20/20 hindsight of independent councils and op ed writers for the New York Times. Cheney agreed with Casper Weinberger, former secretary of defense, "The real world effect often turns out ... not to be a transfer of power from the President to Congress, but a denial of power to the government as a whole." ${ }^{33}$

The recovery of presidential power required in the first instance, Cheney believed, secrecy. His insistence on secrecy was not, in his judgment, a personal cartoonish eccentricity. The executive branch of government needs to get candid advice even in ordinary times on such matters as energy policy without the intrusions and distractions of Congress and the press. After 9/11, policies not only on energy but on immigration, the treatment of prisoners, surveillance, and much else, in his view, belonged under the blanket of security needs. Because the enemy might see patterns in bits of information-however harmless - the government should be able to shut down without explanation the public's right to know. ${ }^{34}$

Meanwhile, conversely, the Bush-Cheney White House insisted on expanding its own right to know. It proceeded with warrantless wiretapping (and with nondisclosure of noncompliance) on the grounds that neither Congress nor the courts could constrain the president in fulfilling his duty. So urgent was the duty to protect the nation's security that the president could suspend treaty restraints and the country's Code of Military Justice in obtaining information from unlawful combatants without pursuing authorization for these prohibited activities from Congress and the courts. In fact, pursuing authorization would be a mistake, even if one had good reason to know that approval would be forthcoming. It would concede too much to Congress and the courts, as though the power

\footnotetext{
${ }^{33}$ Charlie Savage, Takeover: The Return of the Imperial Presidency and the Subversion of American Democracy (New York: Little, Brown and Company, 2007), 60.

${ }^{34}$ Ibid., 102.
} 
was theirs in the first instance. Thus, the right to know and the right not to be known were vested in the president's office. Sealed off from the constraints of the Geneva convention, Congress, and the courts, the president's accountability would effectively narrow to quadrennial elections.

In further expanding presidential power, the Bush-Cheney White House relied more heavily than did earlier occupants of the White House on the device of signing statements, which declare intention to enforce only particular provisions of a law. Therewith the president claimed for his office the de facto power of a line-item veto and dealt preemptively with the issue of the constitutionality of some of the law's provisions, including provisions for regular professional reports and for congressional or judicial oversight, on the grounds that such provisions diminish the president's executive authority. Given the secretiveness of the president's office, signing statements were particularly vexing to those who held to the importance of checks and balances. Signing statements challenged the constitutional powers of Congress and the courts while denying to these bodies the information they needed to mount a counter challenge.

The presidential party also propounded a unitary executive theory, which further extended presidential power. It rejected the notion that other branches of government shared some power with the executive branch, either through congressional oversight or through the existence of relatively autonomous agencies (independent of the president's power to hire and fire at will), which might issue reports and decisions, not subject to the administration's editorial review. This strict, top-down exercise of authority curtailed substantially the possibility of independent professional, scientific, legal, and professional judgments issuing out of the executive branch unfiltered by the president's political agenda.

The administration viewed its strengthening of executive power through the unitary executive theory as restoring rather than breaking with the past. The president himself looked to Theodore Roosevelt as his hero in the wielding of power. John Yoo, head of the Office of Legal Counsel in the Justice Department, and others cited the actions of Presidents Wilson, Franklin D. Roosevelt, Truman, Johnson, Nixon, and Reagan as showing the way toward a more powerful presidency.

Most important, the presidentialists held that the Constitution itself supports this unitary executive theory. Alexander Hamilton had argued in "The Federalist No. 69" and "The Federalist No. 70" that the founders wisely vested executive leadership in a president, not in a committee and certainly not in a swarm of congressmen. Unity was the indispensable precondition of strong energetic lead- 
ership. Only a President could act with "decision, activity, secrecy, and dispatch" (No. 70). John Yoo stretched out such "unity" at the head into a unitary power and command down the line with impermeable borders. He saw overlaps with the other branches of government as an inadmissible weakening of the president's power.

Critics of this unitary executive theory remind us that Alexander Hamilton is not the sole founding father of the country. The other great author of the Federalist Papers, James Madison, insisted on checks and balances in the exercise of power. The founders embedded checks and balances in the Constitution and, in the course of its ratification, the country insisted upon a Bill of Rights, because the nation might face the threat of tyranny not simply from abroad but from within.

Furthermore, critics argue that Hamilton himself, in the very same paragraph in which he defends vesting executive power in a single hand, not a committee, also insists that a "numerous legislature" is "best adapted to deliberation and wisdom, and best calculated to conciliate the confidence of the people, and to pursue their privileges and interests" (No. 70). Yoo also ignored the balance in Hamilton's paragraph. Hamilton carefully circumscribed the meaning of the president's role as commander in chief, as Yoo does not. Gary Wills has noted that Hamilton defined the president as "commander-in-chief" in the sense of "first general of the army" (No. 69). ${ }^{35}$ He did not refer to the president as the commander-in-chief of the United States. That title would have bestowed upon the president a kind of priority and preponderance of power in relation to the other branches of government, the public, and the Constitution itself, which did not obtain then and should not obtain now.

\section{Limiting the Imperial Self}

A deep irony abounds in American history. Liberals, radicals, and conservatives-for different reasons in the last century - have inveighed against imperialistic and oppressive institutions. But they have not recognized that beneath imperialistic institutions often lies an equally imperial concept of the self. The need to placate the imperial self helps explain the air of unreality that haunted the second Bush administration. It sounded the alarm for a world-historical struggle against terrorists and tyrants; yet it did not call for sacrifices from all Americans in the struggle. It rejected tax hikes to pay for the war; it dismissed

${ }^{35}$ Gary Wills, The New York Times. Op ed., January 2007. 
the very idea of a draft, thus relying on those with the humblest of resources to fight it; and it advised the rest of the nation to go shopping. In another era, W. H. Auden dealt with similar ironies in behavior when he warned of: "The snarl of the abyss/That always lies just underneath/Our jolly picnic on the heath/Of the agreeable ..."

In its policies, the administration has scrupulously deferred to an imperial understanding of the self, calling for no serious limitations on our way of life.

How may we define the imperial self so that it does not trivialize into some Napoleonic caricature? The literary critic Quentin Anderson, in his study of Emerson, Thoreau, and Whitman, recognized the imperial self as the self that accepts no limitations upon itself at the hands of others. ${ }^{36}$ It resents intrusions from the public realm. It does not invest itself in strong, nurturing, and self-restraining institutions. For the latter, a society must cultivate the civic self.

The civic self, as opposed to the imperial self, understands and accepts itself as limited and amplified by others. Subjectively, the civic self has learned how to move out of the arena of purely private preference and act, however imperfectly, in concert with others. Objectively, this work in concert with others must serveat least in part-the common good. A society wholly driven by imperial selfinterest would tear itself to pieces-no matter how ingenious its constitutional safety mechanisms of checks and balances-if it did not also cultivate the civic self. That is why the leaders of the revolutionary (more than the immediately following constitutional) period recognized the importance of "public virtue" in a citizenry. "No phrase except 'liberty' was invoked more often by the revolutionaries than the "public good." "'37 Public virtue implies some readiness to sacrifice self-interest to the common good. ${ }^{38}$

Such sacrifices for the common good are important, both in the domain of politics and in the setting of what Edmond Burke called "the little platoons amongst us." Sociologists have dubbed the latter less elegantly "intermediate institutions" - neither the government nor the solitary individual-upon which

\footnotetext{
${ }^{36}$ Quentin Anderson, The Imperial Self: An Essay in American Literary and Cultural History (New York: Alfred A. Knopf, 1971).

${ }^{37}$ Mortimer J. Adler and William Gorman, The American Testament (New York: Praeger, 1975), 87.

${ }^{38}$ See Gordon S. Wood, The Creation of the American Republic (New York: W.W. Norton \& Co., 1972), 68 .
} 
the health and vigor of our common life depends. Such intermediate institutions include professional societies, neighborhood associations, religious congregations, and countless others. They have their own particular interests, but when they do their work well, they are not merely interest groups. They are also publics within the public at large, keeping at least one eye on the question of the common good. The discipline with which such publics act should serve as a brake both on the intemperate wants of the imperial self and on the ill-considered projects of an imperial government. At the same time, the habits of sacrifice they engender should help sustain those national policies that call for self and group expenditures on behalf of just causes.

Religious congregations, to the degree that they act as publics within the public at large and not merely as interest groups, are engaged in cultivating the civic self. They surely do not exist or meet for that sole purpose. But in the course of their common life, congregations learn something about the art of acting in concert with others for the common good. Rabbis, priests, ministers, and imams lead groups of people of all stripes and purposes and cross-purposes. Their communities debate over commitments of time and money and reach decisions about priorities in common cause. And even though their leaders have done little to engage in what used to be called social action or in the cutting edge of a prophetic ministry, such leaders in marrying and burying Democrats as well as Republicans, hawks as well as doves, and in drawing together people who may be recalcitrant and at odds, are engaged in building up indirectly the soil in which democratic institutions may flourish.

\section{Taking to Heart Monotheism in Dealing with Dualists}

In the foregoing, I have not called the dualist movement—currently still forceful in our politics-the "Christian right." Strictly speaking, its adherents, whether denominationally affiliated or not, urge upon the country not Christianity but a different religion: dualism, not monotheism. St. Augustine was the founding theologian in the West who recognized what was at stake here. In his great treatise on the dualism of his time, he did not locate the Manichaean dualists on a spectrum of Christian left, center, and right, as though he were describing simply different colorations of the same thing.

The metaphor of a spectrum of left, center, and right (which the modern media regularly imply when they refer to a Christian right) assumes a single beam of light which refracts into different colors. Augustine recognized, to the contrary, that the dualists threw a different beam of light altogether, not simply 
an alternative shade of Christian monotheism. They were not a Christian right, they were something different; and they were wrong. Augustine made a second, even more important, point. He recognized the lure of dualism in us all. He himself had spent nine years as "a hearer" among the Manichees, attracted at first to the instant clarity they offered in the struggle of good and evil. He finally rejected dualism.

However, taking to heart his monotheism, Augustine also warned against adopting a dualistic view of dualists. He declared that "to heal heretics is better than to destroy them." God's will is "that they should be amended rather than destroyed. And in every case ... we must believe that the designed effect is the healing of men, and not their ruin." ${ }^{39}$ St. Augustine recognized that if you want to address the destructive power of dualism at the deepest level, then you had better contain the lure of dualism in your own soul as you deal with them. That cautionary tale has reappeared in the testing events covered in this essay. Israel needed a king to firm itself up against the threat of tyrants from without and to fend off anarchy from within. But it also needed to contain its own runaway fears so as not to install within its own life the arbitrary powers it feared.

The founders of the United States of America, having gone through thirteen years of ineffective national government, came to see the need for a stronger national executive and legislative authority to overcome the weakness of the former colonies in dealing with overseas tyrants and pirates on the high seas and rebellions from within. But they built checks and balances into the Constitution and they encouraged the cultivation of the civic self so as to bequeath a society more spaciously conceived than a nation obsessed with its security alone. That imperfect republic, eventually grown powerful, has undergone two successive waves of anxiety across the last sixty years, but it must not let an uncontained fear reconfigure it into shapes it professes to detest.

Most tellingly, however, St. Augustine offers a final warning to monotheists on the current scene. Monotheists will succumb to their own spiritual temptations if they simply slam the door shut on the dualists in their midst and create a reflexive dualism of their own-identifying the bad guys with any given set of threatening dualists and the good guys with the shifting band of monotheists in the churches. Believers in God as the Alpha and Omega owe God a more hopeful, open, and confident politics than that, as they persist in working with

\footnotetext{
${ }^{39}$ St. Augustine, "Against the Epistle of the Manichees Called Fundamental," chap.1 in The Nicene and Post-Nicene Fathers First Series, vol. 4, 29.
} 
all sorts and conditions of men and women--irregular libertarians and wouldbe imperialists, dualists and secularists, and religionists of every stripe-to build spacious, humane, and habitable institutions in the rough terrain of modern politics. A rough terrain, indeed, but whoever promised that pursuing the common good would be easy? 


\section{Karl Barth and Contemporary Paganism: Toward a Theology without Nature}

by Benjamin Myers

Dr. Benjamin Myers is a lecturer in systematic theology, School of Theology, Charles Sturt University, Sydney, Australia. He presented a version of this lecture on June 22, 2009, as part of the annual Karl Barth Conference, hosted by Princeton Theological Seminary and cosponsored by the Karl Barth Society of North America.

\section{$H$} world around the middle of the twenty-first century. ${ }^{1}$ Climate change and global warming have unleashed the dark powers of nature. Black blizzards sweep across the cities; the deserts have expanded their vast domain, and creeping sand hills worm their way across the desert wastes; the poor and underprivileged are forced to survive out "in the weather," while those with wealthier means live together in weatherproof domed settlements. The human race is riven by conflicts: there is a violent global gender war between militant "Gynarchist" tribes (whose aim is the feminization of the human race) and powerful "phallocratic" groups (who want to reintroduce polygamy and the subjection of women to men). Human gifts and talents are genetically manufactured. Human life subsists under a chilling pharmacracy: genetic analysis diagnoses one's precise varieties of depression and mental instability, and each person is duly medicated throughout life.

But perhaps the most fascinating and insightful aspect of this dystopian novel is its portrayal of religion. Alongside the planet's environmental degradation, there has flowered a great movement of pagan earth religion, a fervent celebration of nature's glory even as nature itself is crumbling away to dust. The devout are known as "Gaians": they worship the great goddess Mother Earth, and they seek the holy grail of Gaian Consciousness, a sublime mystical immersion into the

\footnotetext{
${ }^{1}$ Hugh Nissenson, The Song of the Earth: A Novel (Chapel Hill: Algonquin Books, 2001).
} 
totality of nature. "You gain Gaian Consciousness by meditating on ... 'Gaia's face' - the natural world in any and all of its manifestations." "2 The faithful gather and sing their "vision songs," while they dance round and round in circles on the lawn:

We love our Mother Earth,

Our Mother Earth who gave us birth.

We love to dance, we love to sing

And drink from Her living spring.

We love to feel our union flow,

While round and round like Her we go. ${ }^{3}$

The novel shows great insight, I think, in this portrayal of a future world marked by a peculiar coupling of ecological catastrophe on the one hand and a flourishing of pagan ritualistic devotion on the other. One does not have to extrapolate very far from our own world to arrive at a picture like this.

The rise of "neopaganism" is one of the defining features of religion in the West today. The 2001 American Religious Identification Survey (ARIS) indicated "that Neopaganism may be one of the fastest-growing new religions-most likely the fastest-in the United States today"; from 1990 to 2001, Wicca increased from 8,000 to 134,000 : a 1,500 percent increase, overwhelmingly comprising white, middle-class, college-educated baby boomers. ${ }^{4}$ Although the movement is often described as "neopagan," most practitioners refer to themselves simply as "pagan." I follow the latter usage in this paper. The term "neopagan" is in any case misleading, because the prefix suggests that contemporary paganism is a rediscovered or revitalized variant of an "Old Religion.". Indeed, most contemporary pagans view their beliefs and practices in continuity with some form of pre-Christian, prepatriarchal earth-based religion. But for historical reasons, which I will explore later, it is best to understand contemporary paganism as descendant not of antiquity but of the movement of western Romanticism in the eighteenth and nineteenth centuries. And this historical observation allows us also to begin to grasp the peculiar theological proximity of contemporary paganism to Christian tradition.

\footnotetext{
${ }^{2}$ Nissenson, Song of the Earth, 169.

${ }^{3}$ Ibid., 93.

${ }^{4}$ These statistics are discussed in Sean McCloud, "New and Alternative American Religions: Changes, Issues, and Trends," in Faith in America: Changes, Challenges, New Directions, Charles H. Lippy, ed., Vol. 1 (Westport: Praeger, 2006), 237-38.

${ }^{5}$ The term "Old Religion" was popularized by Margaret Murray, in her 1929 Encylopedia Britannica entry on "Witchcraft"; the entry is reprinted in The Paganism Reader, Chas S. Clifton and Graham Harvey, eds. (London: Routledge, 2004), 90-94.
} 
In this paper I want to weave together several different threads: pagan theology, nature, Romanticism, Karl Barth's doctrine of creation, and environmental ethics. I should state at the outset that this is not an exercise in interreligious dialogue - an undertaking usually understood in Kantian terms, as rational dialogue staged on a piece of neutral common ground. On the one hand, I am skeptical about the possibility of any "dialogue" framed in these terms ${ }^{6}$; and on the other hand, the close historical and theological relation between Christianity and paganism forces us to ask whether we are dealing here with two different "religions" - a point to which I will return.

This paper, then, is an exercise in theological debate rather than religious dialogue. Taking paganism as a theological position, I want to engage it with some critical questions and to see what happens when it is juxtaposed with Karl Barth's theology of creation. Fundamentally, my aim is to contrast two different theologies-a pagan theology of nature and a Barthian theology of creation-in such a way that the distinctiveness of each theology is clarified and accentuated. Along the way, it is of course possible that we will uncover some points of convergence between the two theologies. But it seems to me that such a discovery can only be the outcome of a serious debate, not an area of commonality that can be posited in advance. First, however, it is necessary to take a closer look at the theological world of contemporary paganism.

\section{PAGAN TheOlOgY}

In The Spiral Dance-probably the pagan movement's single most influential book-the American witch Starhawk argues that pagan beliefs are derived directly "from nature." The goal of pagan practice is "to live close to nature," 8 to submit to "the rule of nature," and to achieve "harmony with nature."10 Because "all things are divine, are manifestations of the Goddess," the pagan practitioner is to "become attuned to the cycles of nature," to this "primal, ecstatic union." 12 Although Starhawk is not a scholarly writer, she vividly evokes the central importance of nature in pagan thought. Nature bears many of

\footnotetext{
${ }^{6}$ For an incisive critique, see John Milbank, "The End of Dialogue," in The Future of Love: Essays in Political Theology (Eugene: Cascade, 2009), 279-300.

7 Starhawk, The Spiral Dance: A Rebirth of the Ancient Religion of the Goddess, 20th anniversary ed. (San Francisco: Harper, 1999), 27.

${ }^{8}$ Starhawk, Spiral Dance, 53.

${ }^{9}$ Ibid., 83.

${ }^{10}$ Ibid.. 35 .

${ }^{11}$ Ibid., 53.

${ }^{12}$ Ibid., 56.
} 
the qualities of divine being, and there is a remarkable immediacy between the pagan practitioner and this divine presence of nature.

If one turns to contemporary pagan scholarship, one finds sophisticated elaboration of the same themes. The most systematic work of theology to come out of the movement is Michael York's important Pagan Theology: Paganism as a World Religion..$^{13}$ The author is both a religious studies academic and a pagan practitioner, and the burden of his book is to show that paganism is not only a legitimate world religion but also a coherent theological vision of the place of human beings in the world. York analyzes a plethora of religious practices characteristic of diverse forms of paganism: practices relating to "animism, pantheism, polytheism, immanentism,... nature worship, numinousness, magic, organicisim, fetishism, and idolatry." 14 And he ventures to narrow this list to two general identifying features that underpin all contemporary paganism: "If we could choose two features that constituted paganism, I would select a thisworldly attitude ... and a recognition of divinity in, or as, matter." 15 In both these central traits, the concept of "nature" looms large; as York observes, pagan practice tends to foreground "nature" as "a chief metaphorical register expressive of the divine." 16 The earth and nature are the "unifying sacred text for the various localized expressions of what can be identified as pagan religions." 17

York even refers to Karl Barth in order to clarify the pagan theology of the divine. While the Christian God is transcendent, the pagan divinity is immanent in nature: "The pagan god is not 'wholly other' (ganz Andere), as is the Christian God. Consequently, paganism's corpospirituality allows for perception of the divine in nature." ${ }^{18}$ Furthermore, York notes that paganism tends to be polytheistic. Because "all of nature" is regarded as spiritually alive, it follows that there may be a multiplicity of divine spirits, including animals, natural phenomena, and so forth, even though nature itself remains the mother of all such gods. ${ }^{19}$ In paganism, therefore, polytheism and pantheism are two sides of the same coin..$^{20}$ Thus, some contemporary pagan scholars suggest not only the term "thealogy"

\footnotetext{
${ }^{13}$ Michael York, Pagan Theology: Paganism as a World Religion (New York: New York University Press, 2003).

${ }^{14}$ Ibid., 65.

${ }^{15}$ Ibid.,

${ }^{16}$ Ibid., 13.

${ }^{17}$ Ibid., 16.

${ }^{18}$ Ibid., 13.

${ }^{19}$ Ibid., 36.

${ }^{20}$ See also Barbara Jane Davy, Introduction to Pagan Studies (Lanham: Rowman Altamira, 2006), 13.
} 
(the study of female divinity) but also "theoilogy" or "polytheology" (the study of multiple gods or goddesses). ${ }^{21}$

York rightly perceives that the reification of "nature" among contemporary pagans introduces an important distinction between western neopagan practices and earlier forms of religious practice. Whereas older religions tended to cultivate techniques of idolatry- "the worship of a physical object as a representation of the divine or ... the sacred itself made manifest" - contemporary pagans tend instead to "reify the whole of nature into a divine object and/or process worthy of worship." Thus "nature itself becomes the idol."22 Paradoxically, idolatry itself is thus eclipsed by a single, all-encompassing idol.

It should be clear that, in pagan discourse, the term "nature" operates as the central theological category. Nature denotes the great Pan, a spiritually infused totality-one is tempted to say (borrowing Augustine's metaphor) that nature is a circle whose center is everywhere and whose circumference is nowhere. As Robert Corrington puts it, "The sacred is in and of nature," and "There is nothing whatsoever outside of nature."23

The concept of nature is also heavily weighted with Romantic and Christian theological connotations. As Barbara Davy observes, there is thus a curious contradiction within the discourse of nature. Pagans tend to idealize the past, to look back to a time "when people lived in harmony with one another and with the rest of the natural world and were more in touch with the divine"24; on the other hand, many pagans see nature "as something that needs to be preserved apart from humans, sometimes as something pure and pristine, as if we have fallen from a natural state." 25 There are sharp tensions in the way "nature" is evoked here. This concept of nature, as I will argue in the next section, bears traces of its complex theological history.

\section{UnNATURAL NATURE}

So what is this nature that we keep hearing so much about—"that blend," as Bruno Latour has memorably put it, "of Greek politics, French Cartesianism, and American parks"? ${ }^{26}$ Even a brief excursion into the history of "nature"

\footnotetext{
${ }^{21}$ Ibid., 14.

${ }^{22}$ York, Pagan Theology, 63-64.

${ }^{23}$ As cited in York, Pagan Theology, 67.

${ }^{24}$ Davy, Introduction to Pagan Studies, 27.

${ }^{25}$ Ibid., 172.

${ }^{26}$ Bruno Latour, Politics of Nature: How to Bring the Sciences into Democracy, trans. Catherine Porter (Cambridge: Harvard University Press, 2004), 5.
} 
reveals that things are not quite as simple as they first appear. I want to take a moment now to sketch a brief genealogy of the idea of nature since the thirteenth century.

For Thomas Aquinas, nature has meaning only in symbiotic relation to supernature. In the Thomistic system, natura is never directly accessible; it is simply a formal concept whose sole purpose is to clarify the meaning of supernatural grace. Hans Urs von Balthasar highlights this point in his account of the Thomistic tradition: "The theological concept of nature is primarily a negative one: it draws a boundary line. It can be distilled into a pure state only through a process of subtraction, because God's original creation was already supernatural to begin with. ... Just as an abstract formal 'blueprint' pervades an actual building without ever being seen as such, so the theological concept of nature pervades the concrete structure of the world without ever being tangible as such."27

Nature is simply a "line," a distinction, an abstraction from the always-already graced condition of creation. The concept has meaning only in contrast to its opposite term, grace. Nature is never simply there: it is never visible or tangible as such, because there is no pure nature independent of grace.

Turning to Calvin in the sixteenth century, one finds a very different understanding of nature. Calvin uses the term in two different, seemingly incompatible ways. ${ }^{28}$ On the one hand, nature may describe the condition of fallen humanity: sin is a "natural" act for fallen creatures, because their very essence has become distorted. On the other hand, nature may also describe the primordial state of moral perfection in which human beings were created; here, "nature" names an original human condition that has been lost. At one point, Calvin combines both usages in a single proposition: "Therefore we declare that man is corrupted through natural vitiation, but a vitiation that did not flow from nature." 29 Human corruption, then, is simultaneously natural (as pertaining to our present state) and contra naturam (as pertaining to our original state). One of these "natures" is an observable object, while the other is a vanished object, something that existed only in the beginning. Faced by such opposing conceptions of nature, one may well ask: do we have direct access to nature, or not? Modern political

${ }^{27}$ Hans Urs von Balthasar, The Theology of Karl Barth: Exposition and Interpretation, trans. Edward T. Oakes (San Francisco: Ignatius Press, 1992), 282-83. Although here I am following Balthasar's interpretation of Thomas, the interpretation is contested in Steven A. Long's new monograph, Natura Pura: On the Recovery of Nature in the Doctrine of Grace (New York: Fordham University Press, 2010).

${ }^{28}$ See the editor's note in Institutes of the Christian Religion, vol. 1, John T. McNeill, ed. (Louisville: Westminster John Knox Press, 1960), 38.

${ }^{29}$ Calvin, Institutes, 2.1.11. 
and religious discourses of nature have largely remained stuck in this fundamental aporia.

In the seventeenth century, the political philosophy of Thomas Hobbes formally adopted one of Calvin's ideas of nature: for Hobbes, the "state of nature" is the original human condition. This is not, however, a paradisal garden from which we have lapsed; it is the dreaded bellum omnium contra omnes, the state of violence and chaos in which all human beings exercise their natural right to selfpreservation. For Hobbes, it is fear of this state of nature that drives individual humans into collective political groups; only in the figure of a political sovereign can we find peace, salvation from nature. ${ }^{30}$ Here, "nature" has meaning only in its symbiotic relation to the state. Nature is simply that from which we are rescued by the sovereign power of the state. Nor is it possible to identify any actual place or time at which this menacing "nature" existed. The term names not a specific empirical locality but a mytho-theological boundary, a point that is always receding into the distant past, a condition of normative evil from which we are always already being rescued.

Among Hobbes's seventeenth-century contemporaries, there were several competing ways of invoking nature. The poet and antiroyalist pamphleteer John Milton appealed to the Genesis creation narrative as an account of humanity's natural condition. Against the royalist doctrine that tried to read the political status quo off the face of a divinely authorized natural order, Milton argued that in fact the law of nature (as revealed in Genesis) demands a revolutionary politics, a politics based not on sovereignty but on the subjective rights of individuals. Milton insisted that his own political position was "meerly naturall" way, he sought to naturalize his own account of nature. Milton rightly perceived that political debate tends to center precisely on the question of the nature of nature, on what counts as normatively "natural." Whereas Hobbes saw nature as a normative condition of evil, Milton insisted that nature is the original paradise, the time before monarchies existed, the place where human beings were free and uninhibited by external authority. Again, if we asked Milton exactly where nature can be found, we would be referred not to any actual point in the world's history, but to a mythical zone, a vanishing point in the primordial past, before our first parents ate the apple.

\footnotetext{
${ }^{30}$ Thomas Hobbes, Leviathan, Richard Tuck, ed. (Cambridge: Cambridge University Press, 1991).

31 John Milton, The Doctrine and Discipline of Divorce (1644); in Complete Prose Works of John Milton, Don M. Wolfe, ed. (New Haven: Yale University Press, 1953-82), 2:602. For an extended analysis of Milton's politics of nature, see Benjamin Myers, "Milton and the Theology of Secular Politics," The Turnbull Library Record 41 (2008): 37-49.
} 
In the century that followed, Jean-Jacques Rousseau articulated a very different theory of nature. For Rousseau, "nature" derives its meaning from a fundamental contrast with civil society. The state of nature was a state of innocence, freedom, and moral "perfectibility." But as humans organized themselves into societies, they became alienated from their natural condition, so that civil society is everywhere characterized by evil and inequality. "Nature has made everything in the best way possible; but we want to do better still, and we spoil everything. ${ }^{933}$ For Rousseau, therefore, nature is not the opposite of grace (as for Aquinas) or sin (as for Calvin) or peace (as for Hobbes) or political tyranny (as for Milton): it is the opposite of civiî society. To return to the innocence of nature, one must extricate oneself from the city and from the whole corrupting apparatus of bourgeois social life.

Meanwhile, Rousseau's British contemporary David Hume advanced a stinging critique of the whole idea of a state of nature. The notion of some original, normative, natural condition, he observed, is a "mere philosophical fiction, which never had, and never cou'd have any reality." There is no state of presocial humanity to which we can look back; instead, humanity's "very first state and situation may justly be esteem'd social." ${ }^{\prime 34}$ For Hume, then, civil society is not a later development against the dark or glorious backdrop of an earlier natural state, as there is nothing more "natural" to human beings than sociality. The quest to return to nature is thus a mirage. There is no nature out there, nothing more "natural" for human beings than cities, government, law, and the virtues of civil society.

If we move from the domain of politics to that of science, we find that nature has again begun to change shape. In the nineteenth century, nature became an object of scientific, medical, and psychiatric inquiry; here, nature stands for that which is normal, healthy, normative, in distinction from all those pathological deviations which it is the task of science to diagnose. As the new medical and psychiatric institutions produced an ever more precise codification of pathologies, so the normative standard of "the natural" became empirically ever more elusive. One may never actually lay eyes on the normal/natural-and one certainly cannot calculate it according to any statistical average, given that nearly all observed cases will be pathological—but this elusive "nature" nevertheless

${ }^{32}$ Jean-Jacques Rousseau, Discourse on the Origin and Foundations of Inequality among Men, in Rousseau: The Discourses and Other Early Political Writings, Victor Gourevitch, ed. (Cambridge: Cambridge University Press, 1997).

${ }^{33}$ As cited in George Armstrong Kelly, "A General Overview," in The Cambridge Companion to Rousseau (Cambridge: Cambridge University Press, 2001), 9.

${ }^{34}$ David Hume, A Treatise of Human Nature, David F. Norton and Mary J. Norton, eds.

(Oxford: Clarendon Press, 2007), 3.2.2. 
forms the whole basis of the scientific diagnosis of abnormality. ${ }^{35}$ Here, nature bears clear traces of its theological past. Like the mythical nature that existed only in the primordial past, it functions as a normative authority that has nevertheless always already receded from view. We are not quite sure what nature is; all we know is that it is always somewhere else.

Traces of these competing ideas of nature, and of their theological roots, still linger with us today. But in our contemporary domains of theological and environmental discourse, the concept of nature is above all indebted to the Romanticism of the eighteenth and nineteenth centuries. Reacting vehemently against the forces of mass urbanization, scientific rationalism, and industrialization, the Romantics sought to "return" to nature, to recover a former glory that had been tragically eclipsed by the artifice of human societies. William Wordsworth's 1798 poem provides a typical example:

\section{Therefore am I still}

A lover of the meadows and the woods,

And mountains; and of all that we behold

From this green earth; of all the mighty world

Of eye, and ear, - both what they half create,

And what perceive; well pleased to recognise

In nature and the language of the sense

The anchor of my purest thoughts, the nurse,

The guide, the guardian of my heart, and soul

Of all my mortal being. ${ }^{36}$

For the Romantic poets, as Timothy Morton observes, nature became "a transcendental principle. ${ }^{\prime 37}$ And the elevation of nature went hand in hand with an elimination of any transcendent creator God, so that, by the mid-nineteenth century, "the composite goddess of nature" had become "the single mighty source of all being." ${ }^{38}$ The Romantics' emphasis on physical environment should not blind

\footnotetext{
${ }^{35}$ On the medical history, see Georges Canguilhem, The Normal and the Pathological, trans. Carolyn R. Fawcett (New York: Zone Books, 1991); and on the history of these concepts in criminal psychiatry, see Michel Foucault, Abnormal: Lectures at the Collège de France, 1974-1975, trans. Graham Burchell (New York: Picador, 2003).

${ }^{36}$ William Wordsworth, "Lines Composed a Few Miles above Tintern Abbey" (1798); in The Poetical Works of William Wordsworth, 5 vols., Ernest de Selincourt and Helen Darbishire, eds. (Oxford: Clarendon Press, 1966-70).

${ }^{37}$ Timothy Morton, Ecology without Nature: Rethinking Environmental Aesthetics (Cambridge: Harvard University Press, 2007), 5.

${ }^{38}$ Ronald Hutton, Triumph of the Moon: A History of Modern Pagan Witchcraft (Oxford:

Oxford University Press, 2001), 35.
} 
us to the fact that their real concern was with the relation between nature and the human soul. For them, nature is "a transcendental term in a material mask." 39

In the Romantic doctrine, nature again remains a vanishing point in the distance. The idea of "wilderness" illustrates this strikingly. Wilderness implies a distance both from one's present location and from all human contact. As Morton observes: "This distance is not an empirical one, but a social and psychological one. ... If you came close, say, by actually living in one, then it would no longer be a wilderness." 40 The Romantic impulse-like the central impulse of contemporary pagan theology - is to get back to nature. But nature is always somewhere else; it is a place one has never been and to which one can never "get back." The Romantic subject, to quote Wordsworth once more, is that person who perceives "about him which way e'er he goes / Something on every side concealed from view." the periphery of one's vision. One can never return to nature, because nature is, by definition, the zone that is remote and untouched by human contact. One can never enter this lost paradise; homo sapiens bars the gate.

This very sketchy and selective genealogy is already enough to show that nature is a rather elusive thing and, indeed, that there is nothing "natural" about nature. On the one hand, nature is always a contested zone; it is not simply "there" as an objective entity available to direct access. On the other hand, talk about nature is (by definition) always naturalizing: that which we invoke as "natural" appears as normative, neutral, self-evident to reason. Nature thus always poses as that which is most neutral, most objective; yet discourses of nature can never be neutral, because any appeal to nature will necessarily be locked in struggle against competing versions of what counts as natural. Nature doesn't come neat; it is always constructed in opposition to a specific thing that is other than nature, and it is always mobilized in opposition to competing appeals to the natural. But

\footnotetext{
${ }^{39}$ Morton, Ecology without Nature, 14.

${ }^{40}$ Ibid., 113.

${ }^{41}$ William Wordsworth, "The Recluse," 1.485-6; in The Poetical Works of William Wordsworth. In Ecology without Nature, Morton offers a very striking analysis of the relation between nature and writing. The Romantic poets urge us to return to nature, to leave the chaos of urban life for the harmony of the wilderness; but the poem itself is the means by which this return to nature is achieved. In Romanticism, nature presents itself to our experience as a kind of text. As an example, Morton (29) cites Denise Levertov's poem: "and as you read / the sea is turning its dark pages." One encounters nature, it seems, not through a bare experience of nature but through writing and reading about such experience. As Morton observes, writing about nature tends to convey the idea that "it would be better for the reader to experience it directly rather than just read about it"; but in order to convey this idea, one has to go on writing: "The more I try to show you what lies beyond this page, the more of a page I have" (30). Morton's conclusion seems to me to be justified: "nature" is not so much a natural pheriomenon as a literary phenomenon.
} 
this is a uniquely slippery concept, because it is always erasing its own tracks, always appearing in the guise of something merely given, something merely "natural" and therefore beyond all debate. As Bruno Latour noted, nature is that transcendental concept whose precise function is to suspend all further discussion: one does not argue with nature. ${ }^{42}$ In any case, I am not trying here simply to make the trivial point that nature is culturally constructed; my point is that this concept is constructed in ways that are inherently problematic, so that theological appeals to nature are rendered internally contradictory and incoherent.

If we return now to contemporary paganism, one might say that its real problem, quite simply, is nature itself. Ronald Hutton, a practicing druid, demonstrated in his magisterial history of neopaganism that this new movement has nothing in common with ancient or preindustrial religious practices. The genealogy recounted by most pagans-tracing their religious movement back to antiquity-must be understood as a theological myth, because, Hutton shows, there are no historical continuities between modern paganism and earlier religions. If we want to understand the origins of this new religious movement, we need look no further than to the Romantic poets. As Hutton argues, "Modern paganism has its direct origin in German Romanticism, the result of a fusion ... of three powerful forces: admiration for ancient Greece, nostalgia for a vanished past, and desire for an organic unity between people, culture, and nature."43 In paganism, the three elements are systematically fused in the theologization of nature: nature is that vanished past to which we must return; and the way to retrieve this past is through the cultivation of an organic unity with the earth.

In a nutshell, the pagan concept of nature is Romanticism writ large: the nature of the Romantics is theologized in such a way that this elusive, never-present zone now becomes the object of religious devotion and of an immense theological nostalgia.

\section{Christianity and Contemporary Paganism}

This historical background can provide important insight into the relation between Christianity and paganism. While pagans tend to understand their belief and practice as "a long-standing alternative to the so-called Judeo-Christian or Abrahamic tradition," Hutton's study amply demonstrates that there has been,

\footnotetext{
${ }^{42}$ Latour, Politics of Nature.

${ }^{43}$ Hutton, Triumph of the Moon, 21.

${ }^{44}$ Chas S. Clifton, Her Hidden Children: The Rise of Wicca and Paganism in America (Lanham: Rowman Altamira, 2006), 41.
} 
from the start, a "Christian element" within the pagan movement, ${ }^{45}$ derived from the particular way in which the Romantic poets themselves blended Christian belief and nature devotion. Among the occult movements that flowered early in the twentieth century, it was sometimes the case that most members of a group were "not just Christians but personally devout Christians," ${ }^{46}$ even while they engaged in practices such as magic and fertility rites. There is every indication that the emergence of paganism in the twentieth century was rendered possible by a particular kind of Christian theological imagination, in which a reverence for creation was translated into a Romanticization of nature and a nostalgia for a preindustrial, agrarian past. A Christian fiction writer such as J. R. R. Tolkien, for example-with his profoundly nostalgic evocation of a harmonious agrarian world-played a major role in the cultivation of the pagan imagination. Indeed, Sarah Pike's chronology of the development of North American paganism lists 1965 as a significant date, as it was then that The Lord of the Rings first appeared in an American paperback edition. ${ }^{47}$

The relation between Christianity and paganism becomes even more entwined when one observes that some of the most influential contemporary pagan writers are directly influenced by the work of Christian theologians. For instance, Starhawk's hugely influential book, The Spiral Dance, is explicitly indebted to the Christian feminist theologian Mary Daly. ${ }^{48}$ More recently, Daly's work is a systematic influence on Paul Reid-Bowen's sophisticated pagan treatise, Goddess as Nature, a book that also deploys the work of Gordon Kaufman and Sallie McFague as a "primary means of interpretative access to Goddess feminism's thealogical method." 49 It must be stressed that such pagan writers do not engage Christian theologians as partners of "interreligious dialogue" but simply as fellow laborers within the field of pagan theology.

Moreover, the influence of paganism subsequently feeds back into much Christian theology, particularly among contemporary ecofeminists, so that it becomes increasingly difficult to draw any clear line between paganism on the one hand and Christian tradition on the other. The work of Rosemary Radford Ruether is a case in point. Ruether adopts a theological version of James Lovelock's Gaia hypothesis. The earth is a single living organism in a "constant process of adap-

\footnotetext{
${ }^{45}$ Hutton, Triumph of the Moon, 163.

${ }^{46}$ Ibid., 166.

${ }^{47}$ Sarah M. Pike, New Age and Neopagan Religions in America (New York: Columbia University Press, 2004), 174.

${ }^{48}$ Especially Daly's work, Beyond God the Father (Boston: Beacon Press, 1973).

${ }^{49}$ Paul Reid-Bowen, Goddess as Nature: Towards a Philosophical Thealogy (Aldershot: Ashgate, 2007), 33.
} 
tation and change"; Ruether identifies this organism as "nature." More than that, nature is a subject, a living and acting "Great Self," a voice that addresses us and summons us into communion. Following the deep ecology of Arne Naess, Ruether thus distinguishes between the "self" of human agency and the "Self" of nature: "The small selves and the Great Self are finally one, for ... she bodies forth in us." Our role is to offer religious surrender to the Goddess of nature; our lives become a prayer to her: "Mother, into your hands I commend my spirit. Use me as you will in your infinite creativity." 50 Similarly, Mark Wallace calls for an earth-centered theology that turns away from "the barren emptiness of modern urban existence" to "lifelong cohabitation with the sacred wilderness of God's mountains and forests." Nature, not the city, is God's "proper abode." 51 We must eradicate any notion that the human species is morally distinct from the rest of nature, so that "our privileged boundaries between human and nonhuman species" are erased. ${ }^{52}$ For Wallace, Christians must look to "the powers of life and death" in order to find "the cycles of the seasons and the rhythms of the wild" that disclose the true nature of things. ${ }^{53}$ Wallace describes his own position as "Christian paganism," a theology of Mother Nature that alone can answer the present ecological crisis. ${ }^{54}$

Alongside such paganizing developments within Christian theology, there have also been remarkable attempts to reorganize Christian liturgy around pagan beliefs and festivals. Several years ago, United Church of Christ minister Richard Kuykendall published Liturgies of the Earth, a book of Christian liturgies organized around the pagan calendar, emphasizing "the inherent goodness and sacredness" of the earth and the need to restore human interconnectedness with nature "through rituals and liturgies which sing an ancient song of the cycle of life." ${ }^{55}$ Kuykendall's central claim is that, alongside the holy days of Christian tradition, the earth has its own holy days. By appropriating pagan seasons and festivals-Maypole dances, invocation of the four elements, and the like - we can connect with the earth's own sacred life. More recently, a series of liturgical texts by Christine Hoff Kraemer attempts to foreground "holism, interconnection, and natural imagery, as well as identifying creation with the body of

\footnotetext{
${ }^{50}$ Rosemary Radford Ruether, Gaia and God: An Ecofeminist Theology of Earth Healing (San Francisco: Harper, 1992), 253.

${ }^{51}$ Mark I. Wallace, "The Wild Bird Who Heals: Recovering the Spirit in Nature," Theology

Today 50, 1 (1993): 21.

52 Ibid., 19-20.

${ }^{53}$ Ibid., 23.

${ }^{54}$ Ibid., 16.

${ }^{55}$ Richard E. Kuykendall, Liturgies of the Earth (Phoenix: Educational Ministries, 1992), 5.
} 
God." 56 Kraemer develops a liturgical cycle based on eight pagan festivals; she observes that "neopagan theology, which ... thinks of the earth as the body of its deities, is an excellent source to draw from" in Christian liturgy. Each of her liturgies begins with an invocation of the "Spirits" or "Energies" of the four elements. For example:

Spirits of the East, spirits of air,

We delight in the caress of your warm breeze....

Spirits of the South, spirits of fire,

We bask in the heat of an early summer sun.

Spirits of the West, spirits of water,

We know you in the pounding of our blood.

Spirits of the North, spirits of earth,

We celebrate your boundless fertility...

Source of Being, Mother of all,

We come with joy and gratitude

To celebrate the power of your life-giving love.

Each liturgy is also Eucharistic; the bread and wine both commemorate Jesus and celebrate the earth's good gifts, while at the altar the congregation "honors the sacrifice of God's body the earth."

We are faced, then, with a very complex entanglement between these two theologies: on the one hand, paganism emerges on the soil of Christianity and remains profoundly influenced by Christian theology; and on the other hand, much contemporary Christianity has been shaped, both ethically and theologically, by developments in pagan thought and practice.

This suggests that a Christian engagement with paganism might best be staged not as an interreligious encounter but as an internal debate over the proper priorities of Christian theological tradition. Perhaps paganism is best understood as a sort of estranged child of the Christian faith. Indeed, one pagan writer argues that paganism's theological focus on Gnosis and on the human body is a recovery of "a central feature of most heretical movements in the history of the Christian

${ }^{56}$ Christine Hoff Kraemer, "Ground of Being: An Earth-Centered Liturgy for Christian Churches" (2003). Published online at http://www.inhumandecency.org/christine/8festivalsX .html, accessed January 28, 2011. 
West." "57 This invocation of "heresy" is highly suggestive, because it points to an uneasy proximity between paganism and Christian theology—a relationship that therefore compels the church to reflect on its own doctrinal commitments and priorities. It is not usually a compliment to describe a position as "heretical": but I wonder whether the concept of heresy, as opposed to "religion," might in fact provide a more useful - and ultimately more friendly — way of approaching the debate with paganism, insofar as the question of heresy is understood as a theological challenge to the church itself and not simply as a strategy of power or exclusion. In heresy, the church encounters not merely a curious religious "other"but a strangely recognizable yet dissimilar form of itself, rooted in the soil of its own traditions and imaginative resources.

An encounter staged in these terms demands both attentive understanding and sharp theological clarification. If we are to think of contemporary paganism as a Christian heresy, then my own proposal is that this movement is grounded in a distorted doctrine of creation - a doctrine in which the human vocation of care for creation has passed over into a Romantic theologization of nature, with an ensuing praxis oriented around nature devotion.

Within contemporary paganism, there are two main forms that this theological nature devotion may take. Nature may (this is the usual response) be celebrated as the caring, mothering womb, the source of all love and kindness. In this approach, all the emphasis falls on the sacred feminine; one reconnects with nature by dancing in a field, showing kindness to animals, practicing vegetarianism, and so forth. Or nature may (as in some of the Nordic varieties of contemporary paganism) be revered for its dark and terrible power, its exhilarating cruelty and might. Here, the emphasis falls not on the sacred feminine but on patriarchal and hierarchical structures; one reconnects with nature by dressing in warrior raiment, by engaging in the hunt, and by sacrifice, libation, and carnivorous feasting. These two varieties of contemporary paganism have an uneasy relationship, because, on the surface, their outlooks and practices seem antithetical. But as Marion Bowman documented, ${ }^{58}$ these very different pagan groups nevertheless band together and perceive each other to be members of a wider pagan family, united by their ritual and theological devotion to nature. For all their differences, they are two sides of the same coin.

\footnotetext{
${ }^{57}$ Morris Berman, Coming to Our Senses: Body and Spirit in the Hidden History of the West (New York: Simon \& Schuster, 1989), 138.

${ }^{58}$ Marion Bowman, "Nature, the Natural and Pagan Identity," DISKUS 6 (2000).
} 
Of course, the appropriation of paganism by contemporary Christian theologians and liturgists leans decisively toward the happy side of nature, so that everything centers on the sacred, nurturing kindness of Mother Earth; even the most progressive Christian liturgists with their flowers and their Maypoles would presumably have second thoughts about summoning the congregation to a bloody hunt in the woods as a means of reconnecting with the earth. The real problem with syncretistic pagan-Christian theologies and liturgies lies not in their benign adaptation of rural festivals, but in their uncritical adoption of the transcendental category of nature.

In short, paganism's problem is nature. The concept of nature, the theologization of nature, leads to an impasse. We want to invoke it as a transcendental norm.

But we have never once laid eyes on this "nature"--and in any case it appears to be morally indifferent at best; downright evil at worst. James Lovelock's famous Gaia hypothesis (so deeply influential in contemporary pagan theology, and in the work of many Christian eco-theologians) amply illustrates this point: if Gaia is an all-embracing living organism, then presumably we are meant to revere and love her; but if the human species is a virus that Gaia is bent on exterminating, then our moral response is a good deal more ambiguous. Should we dance around a Maypole, or slaughter an animal? Should we respond to nature with loving devotion, or with fear and horror?

The pagan theology of nature thus leads to an unbearable tangle of problemsand nature itself presents no answers. It is here, at last, that I want to turn to the theology of Karl Barth. I will argue that Barth's doctrine of creation provides resources for rethinking the world without the concept of nature, and for doing so in a way that also takes account of the important ecological and ethical concerns of paganism.

\section{The Doctrine of Creation: Karl Barth}

\section{Knowledge of Creation}

Barth begins his account of creation in Church Dogmatics with the claim that this doctrine is "an article of faith." "59 It is not a philosophical argument or an empirical observation about the nature of the cosmos. It is not a knowledge that is "accessible ... by way of observation and logical thinking." The fact that God

\footnotetext{
${ }^{59}$ Subsequently cited as $C D$. All references are to Karl Barth, Church Dogmatics, 31 vols., new edition (London: T\&T Clark, 2009), with pagination referring to the earlier edition.
} 
created the world is "a secret" that is accessible only to the eyes of faith. ${ }^{60}$ It is a knowledge that can be received only in response to God's own self-witness in the gospel. Indeed, Barth observes that mere observation could lead to all sorts of theories about the nature of the world: we might conclude that the world is eternal, or that it came into existence of its own accord, or even that it has come into being through "wild chance" or the dark designs of a "cosmic monster." 61 From the standpoint of empirical observation, such hypotheses are quite plausible. But belief in God the creator, Barth argues, is not one plausible hypothesis alongside others. It is not the conclusion of any argument or set of observations. Rather, it is knowledge based solely on what God "has told us" in Jesus Christ. ${ }^{62}$

Barth's point is that creation is a distinctively Christian belief; it is by no means identical with a knowledge of "nature." To speak of God the creator is not to assert "a world cause" or "a principle which is superior to the world." 63 To say that God is creator is not to make a metaphysical statement about the world's nature. Indeed, "we may take any view we like of the existence or nature of a world-cause," as long as we realize that such a world cause "is not God," but only a "product of the human mind." 64 Barth's assertion that a supreme being deduced from the world could just as easily be a "cosmic monster" - like the chilling "omnipotent demon" posited by Descartes - is an indication of the essential ambiguity of nature. On its own terms, the world provides no compelling reason to privilege peace and harmony over violence and chaos. There is nothing in the world itself that could disclose to us "the idea of a kindly God." "If Gaia is indeed a divine being, there is no reason to assume that her intentions are benign.

\section{The Soteriological Shape of Creation}

At the basis of Barth's whole doctrine of creation is the claim that God the creator is none other than the one whom Jesus addresses as "Father." We will never arrive at a knowledge of creation by looking to a content-less supreme being as a way of explaining the world. The creator is not a "divine being"; the creator is this particular God, the one who "reveals himself as the creator ... in Jesus Christ his Son through the Holy Spirit." 66 To speak of creation is to speak of the world's relation to this God, the one revealed in the saving history of Jesus. So if

\footnotetext{
${ }^{60}$ Barth, $C D$ III/1, 3-4.

${ }^{61}$ Ibid., 7.

${ }^{62}$ Ibid., 8.

${ }^{63}$ Ibid., I1-12.

${ }^{64}$ Ibid., II.

${ }^{65}$ Ibid., 367.

${ }^{66}$ Ibid., 12.
} 
creation is an article of faith, and if our knowledge of creation is derived from a knowledge of God's saving work in Christ, then one can further say that creation has a soteriological shape. Again, the goodness of the world has nothing to do with "nature"; the world is good because of its relation to Jesus Christ. Barth's famous theses, that creation is the external basis of the covenant and covenant the internal basis of creation, are simply two different ways of saying the same thing: that creation is a soteriological reality.

According to Barth, all God's works "have in view the institution, preservation, and execution of the covenant of grace." "Creation is the "pattern" or "veil" or "form" of covenant; it is the "indispensable basis and presupposition" of God's saving work. ${ }^{68}$ Creation is the necessary condition for salvation. It "prepares and lays the foundation" for God's gracious covenant to be carried out in history. ${ }^{69}$ Using Calvin's theater metaphor, Barth says: "Creation sets the stage for the story of the covenant of grace." "70 The whole creation "is adapted to be a theatre of the covenant which is the purpose of the divine will and accomplishment"-indeed, the created world "is radically incapable of serving any other purpose." "7l Creation is the room, the "space" within which Jesus Christ's saving action will be performed. "The fact that the covenant is the goal of creation is not something which is added later to the reality of the creature. ... It already characterises creation itself and as such, and therefore the being and existence of the creature. ${ }^{.73}$ All creaturely existence, then, is grounded in its relation to God's advent in Jesus Christ.

Here, as elsewhere, Barth draws attention to the teleological character of creation. The created world does not exist "for itself," nor does it inherently possess its own "goal and purpose." Instead, the creature's "meaning and goal and purpose and dignity" lie solely in the fact that God the creator has turned toward it in Jesus Christ. ${ }^{74}$ To be a creature is thus "to be affirmed, elected and accepted by God." 75 Createdness is the outer form within which "the love of God ... moves toward its fulfilment." ${ }^{976}$ Barth can thus describe creation as

\footnotetext{
${ }^{67}$ lbid., 43.

${ }^{68}$ lbid., 44.

${ }^{69}$ Ibid., 66.

${ }^{70}$ lbid., 44.

${ }^{71}$ lbid., 99.

${ }^{72}$ Balthasar, The Theology of Karl Barth, 123-24.

${ }^{73}$ Barth, $C D$ III/1 231.

${ }^{74}$ lbid., 94.

${ }^{75}$ lbid., 364 .

${ }^{76}$ Ibid., 219.
} 
"the prologue and prefiguration of the covenant." 77 In this way, the creature's ordering toward covenant endows the creature with its true meaning and purpose. The creature has no autonomous meaning inherent in itself, no meaning that could be disclosed to reason or empirical observation. It is God who "gives the creature meaning."

What does this mean for the question of "nature"? Fundamentally, it means that the concept of nature has been rendered obsolete. All the work that the term "nature" does for paganism, the term "creation" undertakes in Barth's theology. One cannot posit a hypothetical creaturely nature that exists independently of Jesus Christ. There simply is no such nature. The world is not nature, but creation. Its being and identity are wholly bound up with God's redemptive work in Christ.

\section{The Shadow Side of Creation}

Moreover, in his remarkable doctrine of the "shadow side" of creation, Barth strictly opposes any Romanticization of the created order. Creation has a bright side, to be sure; but this is always accompanied by a more sinister side. "Light exists as well as shadow; there is a positive as well as a negative aspect of creation and creaturely occurrence." ${ }^{79}$ Creation is not only life and joy, it is also "dust and ashes." ${ }^{80}$ The unsettling realities of death, suffering, and limitation are woven into the very fabric of the world. The created order is eloquent in its beauty and harmony, but we must also give ear to its "sad voice," "81 to that melancholy dissonance that philosophers call "natural evil." The creation remains always "fragile and threatened." 82 Barth's position here makes it possible to affirm the element of truth in the pagan picture of nature: "Created order has what we may call its brighter side. But its justification by its Creator and his self-disclosure is not bound up with this brighter side. It is not connected with the fact that the sun shines, that there are blossoms and fruits, pleasing shapes, colours and sounds, realities and groups of realities which preserve and foster life, purposeful relationships and order... The righteousness of creation is not identical with this." ${ }^{83}$ The "very good" of Genesis 1:31 refers not to nature

\footnotetext{
${ }^{77}$ Ibid., 170.

${ }^{78}$ Ibid., 230.

${ }^{79}$ Barth, $C D$ III/3, 295.

${ }^{80}$ Barth, $C D$ III/1, 373.

${ }^{81}$ Ibid., 372.

${ }^{82}$ As Günter Thomas puts it in his brilliant study, "Neue Schöpfung": Theologische Untersuchungen zum "Leben der kommenden Welt" (Neukirchen-Vluyn: Neurkirchener Verlag, 2009), 108-14.

${ }^{83}$ Barth, CD III/1, 370.
} 
as such, not to anything inherent in the world. It does not name the world's brighter side, those elusive fragments of experience that the Romantics called "nature." Nor does this "very good" refer to any original state of harmony and perfection. For Barth, the story of creation and fall in Genesis 2-3 does not describe any primordial perfection from which we have since lapsed (so that salvation could be understood as a nostalgic return to an earlier state). In Barth's words: "There never was a golden age. There is no point looking back to one. The first human was immediately the first sinner." ${ }^{84}$ The divine "very good" thus cannot be coordinated with any primordial "nature"; the world is not "naturally" good either in its origins or in its own inherent being. The world is good, rather, simply on account of "the divine good-pleasure resting on the created world." ${ }^{85}$ God judges the world to be good; God justifies the world's existence. The world's goodness, then, is not identical with its brighter side, nor is it compromised by the shadow side. Both the light and shadow of creation are included together under the single, justifying divine Yes.

In language that resonates with our own contemporary ecological anxieties, Barth poignantly describes the darker side of creation, insisting that this, too, is justified by God as part of creation's goodness: "The justice of creation is not compromised by the fact that the heavens grow dark, that harmony is engulfed in disharmony and teleology obscured by senselessness." It is not compromised by "the inner lostness of being, despair of the meaning and strength of the human will for life, a sober realisation of [human] limits and of the frailty and end of all things," nor by the melancholy fact that each human being "is lost and must perish." ${ }^{\text {" } 6}$

By its own nature, the created world is what Luther called simul bona et mala, both good and bad. The goodness of creation thus does not inhere "naturally" in the world. In Barth's view, this goodness is an eschatological reality: "When Jesus Christ shall finally return as the Lord and Head of all that God has created, it will also be revealed that both in light and shadow, on the right hand and on the left, everything created was very good and supremely glorious." ${ }^{97}$ The creation is teleologically ordered toward the revelation of God in Christ, and it is this revelation that will finally disclose-or rather, enact-the glorious goodness of creation. It is here that the creation is revealed as theatrum gloriae Dei, the stage on which God's saving purposes are carried out for the good of all things. ${ }^{88}$

\footnotetext{
${ }^{84}$ Barth, CD IV/I, 508.

${ }^{85}$ Barth, $C D$ III/1, 369.

${ }^{86}$ Ibid., 372.

${ }^{87}$ Barth, CD III/3, 296.

${ }^{88}$ See Hendrikus Berkhof, "Barths Lichterlehre im Rahmen der heutigen Theologie, Kirche und Welt," in Karl Barths Lichterlehre (Zurich: Theologischer Verlag, 1978), 33.
} 
Understood as "nature," the world can only be theologically and morally ambiguous. Nature may seem eloquent, but it speaks with a forked tongue. Barth's theology of creation takes all this into account and underscores the fact that any direct theologization of nature will always be deeply problematic.

Paul Santmire is therefore right to observe that Barth's account of the creature's goodness certainly "does not accent the positive"; Barth is very far removed from the Augustinian doctrine of creaturely fecundity, where the creature is an ontologically "good" overflow of the goodness of God. ${ }^{89}$ But while Santmire is uneasy about this accent-because Barth does not speak positively enough about nature-it is, I think, precisely Barth's realistic assessment of the world's ambiguity, his refusal to identify creation with nature, that opens the way to a theologically robust, post-Romantic approach to environmental ethics. .9

In short, Barth's theology gives us resources for un-thinking the necessity of nature, for un-imagining nature's naturalness. This un-thinking of nature is at the same time a re-imagining of the world in the light of Jesus Christ: re-imagining the world not as nature but as creation.

\section{"Let Them Have Dominion": Environmental Ethics}

Later in his doctrine of creation, Barth draws attention to the dominion mandate in Genesis 1:26-28. While theologians today, apparently embarrassed by this text, tend to interpret "dominion" as "stewardship of creation" or "allowing creation to flourish," Barth pursues the theme of dominion as a key to understanding the relation between the created world and its human agents. In Barth's view, God appoints human beings to a unique position of lordship over the created world. Indeed, the whole logic of Barth's doctrine of creation and covenant could scarcely point in any other direction: the creation finds its proper goal in its relation to human beings, or rather in relation to the covenant which God establishes with human beings in Jesus Christ. "The world of animals and plants forms the indispensable living background to the living-space divinely allotted to humanity." Here lies the human's "particularity among other creatures of

\footnotetext{
${ }^{89}$ H. Paul Santmire, The Travail of Nature: The Ambiguous Ecological Promise of Christian Theology (Augsburg: Fortress, 1985), 153.

${ }^{90}$ In contrast, the fact that Santmire's own approach remains mortgaged to Romanticism is plain enough when he suggests that Barth's dogmatics should have included more passages "about the beauties of nature" (Travail of Nature, 155) - as though the only way to develop a responsible environmental ethic were to proclaim nature's beauty all the more adamantly, even in the face of impending ecological disaster.

${ }^{91}$ Barth, CD III $/ 4,350$.
} 
the cosmos." 92 Humans are different from all other creatures, because they are elected to a special role in God's creative-redemptive drama.

This means that the Priestly writer's notion of "dominion" cannot be interpreted in a pagan direction, in a way that collapses the distinction between human beings and the other creatures. As Barth puts it: "The real human cannot merge into his environment. He cannot surrender to it and be assimilated into it. If he did, or even if he could, he would cease to be a real human. He is this creature, and as such he is not another, or a mere component part of a total creaturely reality. Although he belongs to the latter, he is marked off in specific ways from his fellow-creature. ${ }^{.93}$

Reading this passage today, one cannot help thinking of the pagan doctrine of Gaia, a "total reality" that absorbs everything into its own undifferentiated mass. Barth excludes from the outset any such view that would erase the fundamental distinction between human beings and other creatures. Among all creatures, the human is that creature which is elected to exercise lordship.

Proponents of stewardship theories might find this offensive, but one should note that Barth's dominion ethic is set within a larger section on "Respect for Life." The whole emphasis here is on the human's responsibility to nurture, protect, and care for all forms of life, including the life of plants and animals. Barth admits that we don't really know what we are saying when we speak of animal and vegetable life. The word "life" here is analogical, because we have no experience "from within" of these forms of life or of how they relate to our own. Given this fundamental mystery, Barth is quite willing to accept the idea that animals may have souls, or that they may be moved toward relationship with God in some fashion unknown to us. ${ }^{94}$

In this connection, Barth raises pointed ethical questions about the slaughter of animals for food. "The nearness of the animal to man irrevocably means that when man kills a beast he does something which is at least very similar to homicide." $" 95$ One has no right to exercise the freedom to kill for food until one has first seriously confronted this unsettling proximity between animal slaughter and homicide, and has accepted responsibility for such action. Although Barth himself was no vegetarian, he suggests that vegetarianism-in spite of its tendency to "sentimentality" and "fanaticism"- -stands as a necessary witness to the meaning

\footnotetext{
${ }_{92}$ Barth, $C D$ III/2, 78.

${ }_{93}$ Ibid., 78.

${ }^{94}$ Barth, $C D$ III $/ 4,350$.

${ }^{95}$ Ibid., 352.
} 
of human dominion, and as a necessary critique of the "thoughtlessness and hardness of heart" that characterize our relation to the animal world. ${ }^{96}$

Indeed, Barth quotes with approval Albert Schweitzer's remarks on the failure of Christians to allow the animal kingdom to intrude into our ethics. ${ }^{97} \mathrm{He}$ reprimands theologians for their "astonishing indifference and thoughtlessness" regarding animals, ${ }^{98}$ and he insists that Schweitzer's attitude, like that of Francis of Assisi, cannot be dismissed as mere sentimentality. Quoting Schweitzer: "Life as such is holy to [the human being]. He does not pluck a leaf from the tree, or pull a flower, or trample on an insect, ... If he walks along the street after rain and notices an earthworm which has lost its way, he reflects that it must shrivel up in the sun if it does not wriggle in time into the earth, and so he carries it from the death-dealing stones to the grass. If he comes upon an insect that has fallen into a puddle, he takes time to extend a leaf or a reed to save it." 99

As concrete ethical admonition, this may sound extreme even to the sensitive ears of contemporary eco-theologians. But Barth asks, "How do we really justify ourselves if we differ from Schweitzer in this matter?"100 The lordship of human beings is nothing other than a responsibility for other creatures. Humans are placed in an environment "already furnished with these creatures," 101 and they exercise lordship "only in the responsibility thus conferred upon them."102 This means humans must always show a deep concern for the well-being of animals-not because animals have any so-called "rights" (as in some contemporary animal ethics), nor because of the pagan notion that nature will spontaneously thrive and flourish if only we withdraw and let it alone. Rather, the human concern for creation is grounded in the objective relation in which humans stand to other creatures. Like it or not, we are responsible for the animals; our responsibility is identical with our vocation to exercise dominion.

Notably, the passage quoted from Schweitzer does not advocate anything like "stewardship" or a cessation of human intervention in the environment. The moral agent in this passage is very different from the pagan subject who seeks an immersion in nature, and the eventual nullification of the distinction between

\footnotetext{
${ }^{96}$ Ibid., 356.

${ }^{97}$ Ibid., 349.

${ }^{98}$ Ibid., 350.

${ }^{99}$ Ibid., 349; citing Schweitzer's Philosophy of Civilization, trans. C. T. Campion (Buffalo:

Prometheus Books, 1987).

${ }^{100}$ Barth, CD III/4, 349.

${ }^{101}$ Ibid., 350.

${ }^{102}$ Ibid., 351.
} 
human beings and the rest of creation. In contrast, what Schweitzer describes is a deliberate exercise of dominion: the human picks up the earthworm and carries it to safety; she extends a leaf to the drowning insect in order to save it. These actions are examples of human intervention in what one might call the "natural" environment. In each instance, the human contravenes the autonomous rule of "nature," exercising dominion for the sake of the animal.

This takes us a long way from a pagan ethic in which nature is allowed to run its own course, to flourish according to its own autonomous resources. The Genesis story does not have Adam and Eve in a Romantic wilderness but in a garden-not in a "Paradise for 'blessed bliss,' but ... a land which needs tilling and care." 103 So while Santmire has complained that, in Barth's view, "nature ... has no divinely bestowed meaning of its own," ${ }^{104}$ I think Barth's contribution to environmental ethics lies precisely here. The world's "meaning" is not independent of human vocation. The human being is related to the created order in such a way that human action, work, and resourcefulness form a necessary condition for the flourishing of creation. ${ }^{105}$ To put it another way, Schweitzer's earthworm is not part of some undifferentiated totality called "nature": it is part of creation, and that means that a particular relation between earthworms and human beings is already woven into the very fabric of things. When Schweitzer plucks the earthworm from the street, he is not really interfering with nature, but fulfilling the order of creation.

What all this points to is an approach to environmental ethics that affirms the distinction between humans and other creatures, viewing this distinction as the whole basis of moral action and not as some obstacle to be overcome. The point may be clarified if we turn for a moment to Heidegger's distinction between "earth" and "world." For Heidegger, earth is the undifferentiated domain of nature, a sort of shapeless and meaningless jumble of things. World, on the other hand, is produced by human involvement. Unlike earth or nature, world has form and meaning. World is thus not the same as "nature, things, and the universe of beings" 106 ; it is humans who "cast-forth a world." 107 Humans have the unique role of rendering the world, extending ourselves into the world by means of language, ${ }^{108}$ or, as Heidegger puts it, human language is itself "the

\footnotetext{
${ }^{103}$ Claus Westermann, Creation (Minneapolis: Fortress, 1974), 81.

${ }_{104}$ Paul H. Santmire, The Travail of Nature, 153.

105 See Oliver O'Donovan, Resurrection and Moral Order (Grand Rapids: Eerdmans, 1986), 38.

${ }^{106}$ Martin Heidegger, The Basic Problems of Phenomenology, Albert Hofstadter, ed. (Bloomington: Indiana University Press, 1988), 166.

${ }^{107}$ Ibid., 168.

${ }^{108}$ See Martin Heidegger, Elucidations of Hölderlin 's Poetry, trans. Keith Hoeller (New York: Humanity Books, 2000), 56.
} 
worlding of the world." The crucial point here is that there is a reciprocal relation between humans and their environment. The world is nothing else than that domain which is given form and meaning through human activity; and the human is nothing else than that being which steps out beyond itself into a world. This is what Heidegger's concept of Dasein is all about: Dasein is simply that which "has ... stepped out beyond itself, ex-sistere, it is in a world."109 The world becomes itself only through the care and involvement of human beings; and we become human only as we work the world, only as we render it. "The world is something 'subjective,' presupposing that we correspondingly define subjectivity with regard to this phenomenon of world." 110 Dasein, in other words, is that gift which humans simultaneously bestow on the world and receive from the world.

To return to Schweitzer's earthworm: the earthworm is "worlded" by the caring dominion of human involvement; and the identity of the human being is reciprocally constituted by this exercise of dominion. If human being is itself understood as the exercise of dominion-of "lordship," as Barth calls itthen the troubling Cartesian divide between the res cogitans (thinking thing) and the res extensa (entended thing) is no longer in force. Human being is that which extends itself into the world for the world's sake. Human being is vocation. ${ }^{11}$

This insight should drastically change the way we typically think about dominion. Here, there is no preexisting "human nature" that subsequently imposes itself on the world. The human being simply is the exercise of lordship, the action of "worlding the world" so that the proper order of creation is fulfilled. Here, dominion becomes not an imposition but a gift. And it is at this point that one can perceive the deep ethical flaw in a pagan theology of nature. The pagan injunction for humans to be absorbed into the allencompassing totality of nature might sound ecologically sensitive. But what is this, really, if not an elimination of the possibility that human beings could actually gift the world?

Dominion is gift. Barth poignantly captures this insight in his discussion of animal ethics. On the one hand, he affirms the freedom of human beings to tame,

\footnotetext{
${ }^{109}$ Heidegger, The Basic Problems of Phenomenology, 170.

${ }^{110}$ Ibid., 168.

${ }^{111}$ At this point, I agree-on both exegetical and ethical grounds-with Michael Welker's critique of Barth's reading of Genesis 1: the imago Dei should be understood not as sexual differentiation but as the vocation of dominion. See Michael Welker, Creation and Reality, trans. John F. Hoffmeyer (Minneapolis: Fortress, 1999), chap. 5.
} 
harness, and domesticate animals, to bring them into a world, as Heidegger might put it. But on the other hand, he cautions that this exercise of lordship must always take the form of a "careful, considerate, friendly and above all understanding treatment." "112 The human is the one who befriends the world. Not because the world is "nature" but because it is related to God's covenant, because it derives a specific, determinate meaning from the covenant-in short, because it is creation. As humans, we befriend this creation; we exercise our unique ability "to grasp and speak for creation as a whole." "113 We are not merely "stewards," as though God related to the world as to property; or as though we related to the world as to "chattels for which we will have to give account." 114 Our vocation, rather, is to exercise "careful, considerate, friendly" dominion for the world's sake.

Barth illustrates the point with a memorable little excursus on horses. "A really good horseman," he insists, "cannot possibly be an ungodly person," 115 because good horsemanship is the perfect embodiment of the proper relation between humans and creation. In the relation between horse and rider, there is dominion: but this dominion is realized in the form of deep understanding and friendly consideration. The horseman, Barth observes, "is so completely at one with his horse" that he takes from it only exactly what it is "willing and glad" to give. ${ }^{116}$ The rider exercises dominion and the horse responds with gladness, because this dominion is not an alien imposition on the horse's nature but a gift in which the horse is permitted to flourish and to find its place within the order of creation.

\section{Conclusion: Theology without Nature}

This paper has taken us down many winding paths. My aim has been to stage a debate between Barth's theology and contemporary paganism-not by approaching paganism as another religion, but by taking it seriously as a rival theological account of creation, an account in which creation is displaced by a "heretical" theology of nature. Of course, my own constructive proposal here does not always stick to the letter of Barth's text. But I have tried to pursue a "Barthian" approach to environmental ethics based on the fundamental insight that our

\footnotetext{
112 Barth, CD III/4, 352.

${ }^{113}$ Richard L. Fern, Nature, God and Humanity: Envisioning an Ethics of Nature (Cambridge: Cambridge University Press, 2002), 211.

${ }^{114}$ Ibid., 213.

${ }^{115}$ Barth, $C D$ III/4, 352.

${ }^{116}$ Ibid., 352.
} 
world is not nature, but creation. We can begin to think theologically about ecological questions only if we first make the difficult attempt at un-imagining the necessity of the Romantic idea of nature, so that the world is re-imagined as God's creature.

Although I have a great deal of sympathy for the environmental and ethical concerns that animate contemporary paganism, this new theology remains mortgaged to a Romantic theologization of nature. Many Christian theologians are turning to pagan ideas of nature in the hope of renewing the church's faith and witness in an ecologically responsible way. But, as I have argued, nature holds out little hope for such renewal. Still, paganism's commitment to an ecologically sensitive theology and to a morally serious environmental ethic should stand as a necessary critique of what Barth calls the church's "hardness of heart" in these matters. And pagan practice should also remind us of the moral impossibility of cordoning off a spiritualized faith from its setting in the physical world.

Following the trail of Barth's thought, I have tried to glimpse the outlines of a theological environmental ethic in which there is no Romanticization of "nature"-in which there is, in fact, no nature at all. Barth's articulation of human dominion points to an ethic that does not erase the distinction between humans and their environment: no sound ethic can have as its goal the elimination of human distinctiveness. Barth's analysis of human dominion invites us to see a reciprocity between human action and the flourishing of the world. The world is rendered, it becomes thick with meaning, through the gift of human dominion, through human care, work, and involvement. It is through this human involvement that the created order is brought to fulfillment, so that the creature becomes an articulate witness to God's covenant.

Moreover, Barth's doctrine of the shadow side of creation invites us to see this whole messy and complicated world - not only its bright side but also the shadow; not only the birds and the trees but also constructed entities such as cities, institutions, art, relationships, virtual environments-to see all this as belonging to the createdness of the world. These things may be understood as "creatures" in the strict Barthian sense: they form part of the "frame" or "context" within which God's covenant action takes place.

A responsible environmental ethic for our time will have to get over the debilitating dream that there is, somewhere out there, a place called "nature," a vanished paradise to which we must return. In our world, there is no pure wilderness, no nature to get back to. Theological reflection on ecology should therefore take much more seriously the centrality of buildings, streets, and urban 
landscapes and the irreducible role of human societies in God's economy and in the economy of creation.

The biblical story of God's way with the world centers not on something called "nature" but on the city: the goal of all creation is not a sublime wilderness, not Gaia but a New Jerusalem. It is here, finally, that the difference between Christian theology and pagan theology is most pronounced: the Christian looks not backward to nature but forward to a better city, whose builder and maker is God. Pagan theology cultivates nostalgia for nature. A Christian theology - a theology without nature-will be marked not by nostalgia but by hope. ${ }^{117}$

${ }^{117}$ In preparing this paper, I benefited greatly from conversations with friends and colleagues, especially Clifford Anderson, Oliver Crisp, Anthony Paul Smith, and Scott Stephens. 


\section{Time, the Lectures, and Redemption}

by Scott W. Sunquist

This is the first of three lectures of the 2009-2010 Princeton Students' Lectures on Mission, delivered by Scott W. Sunquist, Professor of World Christianity at Pittsburgh Theological Seminary. The series was titled, "Time, Cross and Glory: The Christian Movement as the Missio Dei." The introductory lecture was delivered in Miller Chapel on October 27, 2009.

$I$

have been pulling together threads of questions, of hunches of ideas that have been showing up in my research and writing the past twenty-five years, or since I first arrived at Princeton in 1984. Every scholar knows that she or he stands on the shoulders of those who have gone before and works in a community of colleagues asking similar questions, working with much of the same material. Thus, I must acknowledge my indebtedness to Sam and Eileen Moffett, Andrew Walls, David Bosch (1929-1992), Dale T. Irvin, William Burrows, and Ogbu Kalu (1946-2008). In addition, I have been challenged by my thousands of students, both Asian and Western, who have been thinking about this material with an eye to their futures as people who would soon be participating in the Christian movement and who would eventually be subjects of the Christian tradition that others may someday study. With the explosion of information and our recognition that Christianity is a world religion, it is increasingly necessary to do Christian history in community. Please don't blame these people for my indiscretions and misperceptions. I thank them for their support, for suggestions, and for some steering.

I have been greatly influenced by Asian historians. I first went to the Republic of Singapore to teach Asian Christianity. However, there was little interest among my Asian students in their own history, because all of the great, colorful, and informative Christian history books were about figures such as Calvin, Luther, Edwards, and Niebuhr. I learned enough from the writings of Walls, Bosch, and others to know that issues of contextualization were vital for Christian 
development and long-term viability. And so, to make a long story short, I asked a question about a basic resource for studying Asian Christianity and eleven years later and twelve time zones away I stood in Pittsburgh with the first copy of A Dictionary of Asian Christianity ( $[D A C]$ Eerdmans, 2001). Editing that volume brought me into contact with groups of Christians-the Saint Thomas Christians, Presbyterian, Anglican, Roman Catholic, Assembly of God, Lutheran, Baptist-from thirteen different Asian countries. I consider it my second $\mathrm{PhD}$, or my "habilitation." I learned through this experience something of the complexity of the issues of contextualization and Christian vitality when Christianity is a minority faith, struggling for survival in hostile contexts.

About the time I was finishing the $D A C$ project, I received a phone call from Andrew Walls and Fred Norris saying, in brief, that the Kenneth Latourette Scott book needed to be updated. What happened instead is that with the good leadership of Dale Irvin of New York Theological Seminary and William Burrows of Orbis Books, we rethought how Christian history needs to be envisioned, researched, and written. A global history of Christianity needs the sensitivities and insights of the global church, but it must not sacrifice its character as story. And so History of the World Christian Movement came to light through a global community of fifty scholars, and it became two volumes written by two white guys. ${ }^{1}$

\section{OUTLINE OF THE TALKS}

My lectures seek to understand better the compound question: "What is Christianity as a historical movement, and how can we best understand and explain Christianity as God's redemptive work in history?" I want to be clear from the start that this compound question-focusing upon a historical movement, linked to the faith commitment that in Christianity we see something of God's redemptive work-is being asked on the other side of modernity. We can now publicly admit that scholarly neutrality is a myth. I have commitments and assumptions that I believe are more liberating than binding, more general than specific, and less Presbyterian than Christian. I know and you know that history and context influence perception. Our question has two lines of vision, and how we answer this compound question will have both a pedagogical line of development and a practical line. It will influence how we teach and how we live. How we understand Christianity as a movement in history will determine how we teach about Christianity, how we prepare pastors, and how we equip people for Christian

${ }^{1}$ Volume two is due to be published in 2010 . 
witness. What do we focus on, and what do we leave out? What are we looking for in our research? Any historian will tell you that the art of the historian is mostly a matter of deciding what to leave out, so how we answer this question will help us in the art of historical excising.

Thus, our question has an ethical dimension. Having majored in education decades ago, I still am aware of the truth that education is not a neutral science. Jesus talks about the misuse of pedagogy resulting in having a millstone strung around your neck and being thrown in a lake. Teaching is less a matter of throwing facts out in the air and more a matter of shaping, directing, and guiding. Jesus realized that education is a moral undertaking, as did Marx. Politicians running for office also realize this. Minds can be corrupted or corrected; lives can be saved or starved by teachers and scholars. In universities and seminaries we are often so far removed from the "end product" (e.g., the pastor applying the Word to an individual's or a family's life) that we seldom recognize our responsibility and accountability, but I believe that how we answer the above questions about teaching focus and research has moral and ethical implications. It would be much safer if our historical and theological scholarship could be as "neutral" as the description of a slug or as boring as watching grass grow. However, when we teach Christian history, especially in a seminary, we are directing minds and affections; we are building an image of "Church." In all honesty, at times we may just be putting people to sleep. This also has moral implications.

This may seem like an odd topic for a Students' mission lecture, so let me explain. I mentioned that two long global and communal academic projects have shaped my thinking about history. ${ }^{2}$ Two years ago I presented a premature paper on the meaning of Christian history and the writing of Christian history while working on History of the World Christian Movement. The paper was to be an introduction or epilogue (I am often not sure if I am coming or going) for History of the World Christian Movement, Volume II. It was a well-researched paper tracing historiography in the past two centuries that timidly worked toward the conclusion that all of nineteenth- and twentieth-century historiography was leading to our book. As you can see, the paper was not only premature, it was also self-serving. It deserved to be ignored. However, my bad paper and everyone else's evening was redeemed by an insightful question from a South African ethicist. "Scott, you have been reading about Church history globally for the past eight years or so. Few people are forced to read so widely about Christian history: the Pacific and Potomac, the Balkans and Batakland, and of course Pretoria

\footnotetext{
${ }^{2}$ A Dictionary of Asian Christianity and History of the World Christian Movement.
} 
and Princeton. You have had to tell all of this as a single story, to make some sense of various movements as all part of the fabric of Christianity. Tell us, what have you learned?"

It was not the question I was expecting. With his question he graciously swept my paper from our gaze and put on the table something much more solid, precious, and important: the question of meaning, if not of purpose. On one hand I was in shock and wanted to crawl under the table. On the other hand, it was a very simple question to answer. "What I have learned is that Christianity is so fragile, and yet it is powerful enough to change the world." That is it. As I explained this, scenarios from across the centuries and across the seas came to my mind. These scenes all revealed something of the missional meaning of Christianity. Christianity-even under terrible conditions, for sloppy reasons, or with uneducated leaders - is constantly moving out. But as it moves out it transforms cultures. As I was concluding my brief exposition the image came to mind that I will stick with and that I now want to stick on you. Christianity is a thin red thread woven into history, a thin red thread that has changed the world. The thin (and fragile) red thread is the message of Christianity. It is fairly simple. It does not have to be written; in fact, it is usually spoken. It is something like this:

God created all things and in Jesus Christ he came to forgive sin and to show us how to live. His message was rejected, he was killed on the cross, was buried, rose from the dead, and now through his Holy Spirit he continues his work of liberation and redemption of all through the Church.

We may quibble with some of the words here, but this is the basic message. It has been translated, spoken, acted out, sung, and preached, and people and their cultures have been transformed. During the past few years I have expanded that simple image into three concepts of time, cross, and glory.

In answering this question about the meaning of the Christian movement, I will first set the context. I will use the history of these lectures as my canvas, and the early speakers, especially James Dennis, for my paint. After looking at how Christianity was understood in his historic and cultural context of the early twentieth century, we will turn to look at history itself, or more exactly the concept of time. The second lecture will look at Christianity as apostolic and cruciform in essence. To put it negatively, Christianity that is not moving out into lives and cultures or that does not "lay down its life for its friends," is eccentric at best and misrepresenting the faith at worst. The final lecture picks up on the theme of the cross and suffering and notes that the key to the Christian life and to Christian mission is found in a future hope, which passes through suffering to glory. 


\section{History OF THE LECTURES AND History ITSELF}

I have long used James Dennis's three-volume Christian Missions and Social Progress: A Sociological Study of Christian Missions ${ }^{3}$ as a case study in the problems of contextualization and historical understanding. In preparing these lectures, I found out that Dennis, a Presbyterian missionary to Syria and historian of mission, gave the first Students' mission lecture at Princeton, later published as Foreign Missions after a Century. He also gave the fourth lectures, which were later expanded into the massive three-volume work Christian Mission and Social Progress. He was greatly appreciated here, and among Presbyterians in general a century ago, and so I will use his understanding of mission and the Christian movement as a starting point. His views seem so strange and optimistic to us today, so imperialistic and arrogant, and yet his idea of progress was as natural and common in his time as our commonly held ideas that technology holds the answers for the future. Dennis was a progressive-a nineteenth-century progressive evangelical rooted in the American Protestant tradition, the confidence of the Student Volunteer Movement, and the sense of duty that was at times expressed as the "white man's burden."

In the introduction to his first volume of Social Progress, he notes the following: "That there is a striking apologetic import to the aspect of missions herein presented is evident. It is not merely a vindication of the social value of mission work, but it becomes, in proportion to the reality and significance of the facts put in evidence, a present-day supplement to the cumulative argument of history in defense of Christianity as a supreme force in the social regeneration and elevation of the human race." ${ }^{4}$ His view was illustrated in the wealth of facts, stories and pictures that fill the volume.

For Dennis the missionary message is for "worldwide reformation ... or ... regeneration." Listen to his evaluation of history and reform: "We have had local reformations in religious history; we had them in Hebrew history, before the coming of Christ. The result of early Christian labors was the conversion of the Roman Empire and in the sixteenth century came the great historic Reformation of Europe. Now, for the first time in the history of our earth, this great movement in the direction of regeneration or reformation is beginning to shape itself into a world-wide enterprise."

\footnotetext{
${ }^{3}$ New York: Fleming H. Revell, 1897-1906.

${ }^{4}$ James Dennis, Christian Mission and Social Progress: A Sociological Study of Foreign Missions. Volume I (New York: Fleming H. Revell, 1899), ix.

${ }^{5}$ Dennis, 18-19 (emphasis is mine).
} 
The sixteenth-century reformation was only in Europe, thus, he says, "May we not expect that a reformation so extended as that contemplated in modern missions will produce world-wide fruit, especially since it has all the advantages afforded by modern inventions, and facilities and methods of communication, and international relations and the almost magical expedients for disseminating knowledge?" $\mathrm{He}$ and his age had great trust in technology and human inventions. This is what gave him confidence in Christian mission. I do not believe we are that different today, although we express it differently. ${ }^{6}$ His views, however, were not yet chastened by the world wars and genocidal obsessions of the twentieth century. In the preface to Volume III he notes, referring to his previous lectures, "It has been asserted, for example, that missions are a forceful dynamic power in social progress, a molding influence upon national life, and a factor of importance in commercial expansion, as well as a stimulus to the religious reformation not only of individual lives, but of society as a whole, though many and varied channels of influence."?

What may cause us to pause is his seemingly imperialistic view of Christianity ("national life, commercial expansion"), which sounds like a domination of the world by Christian cultures and nations. And yet the evangelization of cultures or penetration of Christian values of justice and peace is something we should affirm. Jesus's life and death was not just a private and privileged act for our own therapy. It was identification with the lost, lonely, and oppressed in order to usher in new relationships, life, and a new society called a Kingdom. The problem with Dennis from our perspective is not how expansive his vision of mission was but how it was woven with national aspirations (a particular society), and reliance upon human efforts. Below are some pictures that help us see through Dennis's eyes how he understood the progress that Christian missions promised.

I cannot emphasize enough that this was the common understanding of western nations and western theologians, even (or especially) the more progressive of the time. The phrase "western nations" includes France. In 1899, as the Ottoman Empire was collapsing, France, England, and Russia were moving into the Middle Eastern neighborhood. The opportunity arose for the Benedictines to rebuild a crusader church in Palestine. In a September 11, 1899, letter from D. Drouhin, OAB (Ordem dos Advogados do Brasil) to French Consul Ernest Auzépy we read the following: "In this surprising concourse of circumstances, there is for us, Mr. Consul, a very precious encouragement: we would gladly say, with our generous Crusaders of the eleventh and twelfth century: God wants it. God wants it! Especially as our consciences and our hearts give their testimony that, like them,

\footnotetext{
${ }^{6}$ We can stop global warming. We can reclaim rivers and lakes. We can end this war, etc.

7 Dennis, vol. 1, preface.
} 
we are only looking for the greatness of our dear France and the extension of God's reign, which for individuals and for peoples is the real, the unique source of civilization and happiness." rialistic than the good French Benedictine brother, but that should give us little solace.

Dennis and Grouhin and, for that matter other great Christian leaders of the early twentieth century-people like John R. Mott, Robert E. Speer, Bishop William Oldham, and Samuel Zwemer-viewed Christianity through their cultural lenses, and when they looked, they saw progress - social progress, in fact. Christianity was advancing and bringing with it a better life for all, a life for the West African or Chinese that would be like the best of western civilization (including the clothes). This basic view was an academic view-the view of the academy-but it was also the Fundamentalist and the Pentecostal view of Christianity. The great historian Kenneth Scott Latourette reflected a similar view, although he was more chastened by the long historical record he traced. Still, he saw each advance of Christianity as progressing a little further and each recession as receding a little less. Optimism, progressivism, and human ability were themes in the historical writing of Christianity. It was easy for them to see the Kingdom of God revealed in modern technology, better health, and the missionary movement.

We now live in a new century, and I would like to propose that we need to re-center or re-view Christianity today. In light of the presence of Christianity today as mostly nonwestern, and in light of the errors of past in equating human technology and empire with Christian mission, meaning must now come out of the biblical story, the experience of the global Church, and it must be in continuity with its founder. Neither Wesley's quadrilatera $1^{9}$ nor the Reformation cry of sola Scriptura is adequate for the twenty-first century. Again, these convictions come out of studying Christian movements through the ages and throughout the world: the biblical story, global Christian experience, and faith as defined by its founder. Keep this in mind as we move forward.

\section{Time AND Redemption: History}

It should have been clear in looking at the pictures from Dennis's book and in hearing his attitude of progress for all nations, that the Christian idea of hope

\footnotetext{
${ }^{8}$ Dominique Trimbur, "Between Eastern and Western Christendom: The Benedictines, France and the Syrian Catholic Church in Jerusalem," in Christianity in the Middle East, Studies in Modern History, Theology and Politics, Anthony O' Mahony, ed. (London: Melisende, 2008), 379.

${ }^{9}$ Scripture, tradition, experience, and reason.
} 
was deeply rooted in this theology. In fact, for all of our criticisms of nineteenthcentury progressivism, social gospel optimism, or student volunteer triumphalism, we can see that the hope of the gospel is expressed in all of these. ${ }^{10}$ In Jesus Christ, hope is offered. It is described as forgiveness, liberation, and redemption, and it comes in many forms. However, in Jesus Christ we believe there is a future, which includes a purpose and goal. History as an ongoing and purposeful story is important.

One of the great tragedies of the modern and now postmodern era is the disdain we have developed for history. In a sense we have ourselves to blame for this, since the antihistorical bias that developed in the Enlightenment was very much a result of the betrayal of religion by western societies. Religion- which is supposed to give solace and comfort, meaning and understanding — had become the crusader against the East and the inquisitor in the West. As Descartes looked over the seventeenth-century battlefields, where Christians were killing other Christians over political power and interpretations of the Eucharist, he believed that all knowledge was misleading. And here was the rub: what we have known through history and tradition has misled us, and so we need to start afresh. What we have been told from history cannot be trusted, so (he reasoned) I have to begin with myself. I can trust myself, reasoned Descartes. Actually, two revolutions occurred at the same time, and we still live with these two today.

The first revolution was a turn away from history and a turn toward the future. This meant a turn away from Christian tradition or the past as having truth. ${ }^{11}$ Truth was to be found in what was modern and what was to come, for the past had betrayed humanity. The second turn was a turn away from God and God's Church to the "self" as the measure of truth. Thus, the scientific method developed, even among well-meaning Christians, at a time when history was on the decline. The Reformation cry of "Ad fontes," "To the source," turned into the Enlightenment cry of Kant, "Sapere Aude!" "Dare to Know!" And knowing involved daring to discover and think something new. In fact, one of the proofs of truth in the modern era is simply that it is new. And so we live with this modern epistemological heresy, where history does not contain knowledge. It makes

\footnotetext{
10 "The evangelization of the world in this generation" became the watchword or mission cry of the 1910 Edinburgh Missionary Conference, indicating that it was a mainstream, mainline understanding of mission.

"Christian tradition is the dynamic life of the gospel, rooted in Jesus Christ and participating (with faithful continuity) in history. The tradition at times becomes captive to cultural expressions, and when this happens it becomes necessary that it be freed through rediscovery and recommitment to its life-giving Spirit. See John McGuckin, The Orthodox Church: An Introduction to its History, Doctrine and Spiritual Culture (London: Wiley-Blackwell, 2008).
} 
it difficult to entice young people to study the past while they are texting to their friends back home: "History is so boring." "Kill history before it kills me."

History, or more exactly, the Christian view of history, is the exact opposite. With the coming of Christ as the Sent One of God came a new view of reality, one that confronted the cyclical views of reality that were common in the Roman Empire as well as among many of the religions of the world at that time. We might say that for the earliest Christians, there was great interest in the discovery that history was God's idea. ${ }^{12}$ The cycle of birth, growth, decay, death, and rebirth was broken when God came to usher in a new Kingdom upon earth that pointed to a fulfillment time in the future. They rightly found the origin of salvation in creation, and so creation became a central, or at least foundational, salvific event. Athanasius begins his discussion of the incarnation (De Incarnatione Verbi Dei) by talking about creation. The one who created humanity is the only one to redeem humanity. This helps to explain why there are so many Patristic commentaries and homilies on Genesis and more specifically on the Hexaemeron ${ }^{13}$ (Ephrem, John Chrysostom, Diodore of Tarsus, Basil, Narsai, Origen, Ambrose, Augustine, Cyril of Alexandria ${ }^{14}$ ). The early defenders of the faith would agree with Martin Luther: "Nihil pulchrius Genesi, nihil utilius." Nothing more beautiful than Genesis, nothing more useful. ${ }^{15}$ The creation of time-expressed as a movement from chaos to order through fall and redemption and then to the new creation-continues to be important today for those whose lives are still cyclical.

This new understanding of reality, where God created all things including time, was a radical break from the common understanding of the ancient world as we see in the Patristic commentaries. This view of time, purpose, and a goal of time continues to be a key issue in Christian witness to Hindus, Buddhists, and those who worship according to the cycles of nature. Missionaries teaching peoples who view time as nonlinear always turn to a single God as creator of all things. Creation becomes the main, or at least the foundational, doctrine to be discussed. For example, the much persecuted, exiled, and imprisoned Jesuit Alexandre de Rhodes, who worked in both Annam and Cochin China, began his "Eight Day Catechism" with a long discussion of creation, explaining each day of creation. Then he talked about the "Three religions" of Vietnam and how they were false,

\footnotetext{
${ }^{12}$ Read the following: Andrew Louth has a section on Maximus's cosmology in his book Maximus the Confessor (from the Routledge series), 63-77. The chapter in John Behr is For This Were We Created in The Mystery of Christ, 73-114.

${ }^{13}$ The six days of creation.

${ }^{14}$ See Fr. Seraphim Rose, Genesis, Creation and Early Man, for other commentaries.

${ }^{15}$ Assuming James Strahan's attribution is correct: Hebrew Ideals: A Study of Genesis 11-50, 4th ed. (Edinburgh: T\&T Clark, 1922), 5. Stanley L. Jaki says the saying is from a nineteenth century French exegete (see: Homiletic and Pastoral Review, August/September, 1993; taken from a reprint).
} 
and then he got around to talking about Jesus. ${ }^{16}$ Lesslie Newbigin remarks in his book Gospel in a Pluralist Society that the Tamil language, dominated by Hinduism, has no word for hope. Creation, time, and fulfillment of time carries with it hope. ${ }^{17}$ Newbigin then comments that this is one of the main marks of a Christian community; it has a future hope. In a number of ethnic groups, such as the Karen, there are myths or national stories about a creator God, who is far away. Embedded in their cyclical lives was a timeless hope of redemption. For the Karen, it was a lost book, for some West African groups there is a creator God, but he has been forgotten. This is not an empirical study, but it has been my experience that when Buddhists become Christians, they are particularly interested in the stories of creation. Creation ex nihilo was understood to mean time (kronos), which meant the possibility of development, change, progression and fulfillment. Jesus's coming marks time and marks humanity. Therefore, the key to time and, by extension, the key to humanity is found in Jesus Christ.

Closely connected to the creation of time was the new concept of creatio ex nihilo. Ancient Christian writers wrote about creation to show that God's redemption is in fact a creation and creative work that God alone has done. We can see how important it was to understand God's absolute creation out of nothing when we look at the response of Patristic authors to Origen. Origen's theology of creation was seen as semiplatonic, and so his views were criticized and his works on creation were not included in the Philokalia..$^{18}$ Creation out of nothing was a radical departure from the Greek view of the world, a world where intermediaries moved between the divine and physical plane. The implications of this radical claim have been spelled out by Andrew Louth. He notes that "both Athanasius and Arius have a very clearly defined doctrine of creatio ex nihilo. This may not seem very surprising until it is realized that the doctrine was unknown to pagan philosophy and only emerged slowly and uncertainly in early Christian theology ... with Athanasius and Arius, there is no doubt, for they enumerate the alternatives and reject them (see De Inc. 2 and Arius's Letter to Eusebius of Nicomedia)."19

\footnotetext{
${ }^{16}$ See Peter Phan's Mission and Catechesis: Alexandre de Rhodes and Inculturation in Seventeenth Century Vietnam (Maryknoll: Orbis, 2006).

${ }^{17}$ Gospel in a Pluralist Society (Grand Rapids: Eerdmans, 1989), 101.

${ }^{18}$ Origen's view of creation and time has recently been reevaluated by Panagiōtēs Tzamalikos (Origen: Cosmology and Ontology of Time, Supplements to Vigiliae Christianae; Brill, 2006), but the historic fact is that Origen's interpretation of the Bible was appreciated by Orthodoxy and is included in the Philokalia, although his views on creation were left out. The Cappadocian Basil of Caesarea explicitly rejected his interpretation of Genesis as being too Platonic. Origen's disembodied eschatology or idealism does not provide adequate basis for social activity on behalf of justice, nor does it promote the cultural mandate, which has been a central pillar of Christian history. ${ }^{19}$ Andrew Louth, The Origins of the Christian Mystical Tradition: from Plato to Denys, 2nd ed. (Oxford: Oxford University Press, 2007), 74.
} 
What this means, says Louth, is that there is a complete contrast between God and his creation or between the divine (uncreated) and that "which is created out of nothing but the will of God." Therefore, there is no intermediate zone, there are no aeons or emanations. It was this intermediate world (posited by Middle Platonism, e.g., Philo) that contained the idea of Logos, but because the Christian view of creation had no middle zone, the Logos had to be identified fully with God (Athanasius and the Orthodox) or with the world (Arius).

The soul, it was soon understood - in contradistinction to Origin-also was created ex nihilo. Thus, Christian mystical theology does not see the soul as part of God. For Athanasius the soul is a mirror of God. Louth comments, "There is no ontological continuity between the image of the mirror and of that which it is the image; so, in the case of the soul reflecting the image of God, this similarity discloses a much deeper dissimilarity at the level of substance." ${ }^{\prime 20}$ For Athanasius the soul is created - it is not part of God. It is something new and different but reflecting something much greater: the image of God. What does this have to do with us?

I believe that as Christians, we may be helped to regain for a moment the wonder of creation and time. Stop arguing about what cannot be known (the how) and affirm afresh the wonder of creation itself (the what) and of the Creator: "I believe in God, the Creator of the Universe and of all things visible and invisible ..." Western societies readily accept the concept of time and hope of a better future. Can we also see in a Dennis, or in the 1910 Edinburgh Conference, the long influence of time, of hope of a creation absolutely dependent upon God the creator? And yet we also see in the first Students' Lectures on Mission misplaced hope. But there is more.

What does this view of time and creation have to do with mission? Everything. We have already seen how the teaching of creation was seen as foundational for teaching about redemption. The message that the Church bears to the world is a message of hope, and this hope begins with the knowledge that God, the Creator of all, has entered into God's creation to restore the image, redeem God's people, and bring forth a new creation. The Gospel message is a message of hope that is being fulfilled in linear time. Time began and time will end. And the end of time means judgment, promise, and glory. We have a sure hope that there will be a time when nations will no longer make or teach war, when God will cover His own with his tent, when his glory will be revealed to the nations, when they will thirst no more, and when God will wipe away every tear from their eyes (Rev. 7). Creation, time, redemption, and glory are of a fabric, and they are the fabric that has become our mission, the mission of God. It is important to remember

${ }^{20}$ Ibid., 77-78. 
God's work in the past and to fully enter--to participate in Christ--in God's future, leading to a sure hope.

Before concluding, we must be honest and note that time and hope can be misused. Thus, it is important for us to be clear about Christianity and time as we look at disparate movements that claim the title "Christian." There is a view of time that believes that the future hope can be realized in our very missionary work today. This is the voice of James Dennis and many of our Church leaders in the Progressive Era. There are others who see the hope of the Gospel without embracing its humility and patience. During the period of sixteenthcentury reforms, they were known as revolutionary radicals. In China in the nineteenth century, they were known as the Heavenly Kingdom of Great Peace, or the Taipings (1850-1864). The Taipings were a separatist kingdom split off in a long-fought civil war. The Taiping Rebellion (as it is called) was a revolt against the oppressive rule of the Qing, and it was inspired by the Apocalyptic Christian-influenced teachings of Hong Xiuquan (1814-1864). As with most renewals, there was a concern for justice. However, this "renewal" movement can and must be judged for its misunderstanding of the message, the Messiah, and meaning of hope.

Hong was a Hakka Chinese ("guest people") from near Canton who read Chinese-produced materials about Jesus Christ: Good Word for Exhorting the Age, written by London Missionary Society missionary William Milne's assistant translator and convert, Liang Afa. ${ }^{21}$ Hong was influenced by these writings and by visions, his readings of Confucian texts, selective reading of the recently translated Bible, and of course the social oppression and poverty of late Qing China. Hong's Heavenly Kingdom of Great Peace became a unique Chinese religion based upon a realized eschatology: the kingdom of heaven is here and Hong is the younger brother of Jesus who is elevated to the place of Heavenly King (Tian Wang). The Heavenly Kingdom developed a massive army of soldiers who memorized the Ten Commandments and who were copying Bibles by the thousands. The Kingdom was first centered in a strong Hakka region (Guangxi Province, where Gutzlaff's Chinese missionaries had made many converts in the early part of the nineteenth century), but then they captured Nanjing with over 750,000 soldiers. For a decade the Kingdom attempted to conquer all of China from this base, the southern Chinese capital. The movement was strongly Biblicist-opposed to idolatry, foot binding, and corruption — and very communal (sharing goods, etc.). The Kingdom collapsed as much by internal disorder and

\footnotetext{
${ }^{21}$ See Samuel A. Moffett's A History of Christianity in Asia, Volume II (San Francisco: HarperSanFrancisco, 1995) for a full discussion of the historic context of this movement.
} 
murder as by Qing government pressure. It is estimated that between twenty and thirty million people died in this massive civil war, making it one of the most destructive wars in history. It was clear that many of the elements of Christianity found a home in the Chinese heart, but at the core of this movement was the hope that Qing and war lord corruption and violence could be ended and a Kingdom of Heavenly Peace could become a reality.

Nearly thirty million deaths. Our American Civil War resulted in about two thirds of one million dead. Unless we have clarity about Christian history, we will have a hard time giving a clear critique of Hong's Heavenly Kingdom, or Dennis's earthly kingdom. We can describe these events, but future generations need for us to give moral and ethical guidance. What went wrong? Is Hong's Christian Kingdom also Christianity? If not, what is it and on what basis can I judge his zeal for righteousness and justice? 


\section{Blood Done Sign Our Names: \\ Blues, Gospel, and Jazz Impulses in the Age of Obama}

by Timothy B. Tyson

Timothy B. Tyson gave this 2009-2010 Frederick Neumann Memorial Lecture at Princeton Theological Seminary on November 2 in the Main Lounge of the Mackay Campus Center. Dr. Tyson is senior scholar at the Center for Documentary Studies at Duke University and visiting professor of American Christianity and Southern Culture at Duke Divinity School. He is the author of Radio Free Dixie: Robert F. Williams and the Roots of Black Power.

ver the years, people have had a tendency to wonder about me. What's with this guy and all the "black stuff"? Back when I first started doing African American history, I would show up and present my paper on Robert F. Williams and the roots of Black Power or the Wilmington Race Riot of 1898, and that was inevitably the first question-and sometimes the second and third: "Why do you write this history?"

I was patient with these questions, but I also recognized that they were particular to my historical moment. Nobody ever asked the Irish-American scholar of the Italian Renaissance why on earth she studied the Italian Renaissance. People just assumed that she was interested in the Italian Renaissance-a real subject, worthy of her interest-and either listened to her or fell asleep, but it was okay. Not so with the white boy from eastern North Carolina studying the Black Power movement: wander off the plantation and they want to see your papers.

Of course, these days many of us consider the categories in a more flexible and eclectic way. My most recent book, Blood Done Sign My Name, seems to answer some questions in advance. ${ }^{1}$ The book is part history and part memoir. It recounts a racial murder committed by the father of a childhood friend the year

\footnotetext{
${ }^{1}$ Timothy B. Tyson, Blood Done Sign My Name (New York: Crown, 2004).
}

DOI: $10.3754 / 1937-8386.2009 .30 .13$ 
I turned eleven and the African American insurrection in my hometown that followed. I went back and interviewed murderers, arsonists, Klansmen, rioters, witnesses, lawyers, activists, and anyone else in Oxford, North Carolina, who would talk to me. My parents let me use their diaries. I ransacked traditional historical sources such as newspapers, investigative files, and court documents. But I wrote the story in first person. People read what happened in my hometown and to my family and they say, "Oh, so that's what got into him." Or as we might say in the South, "Bless his heart, he can't help it."

I am so glad to be here at Princeton, and I want to thank President Torrance for his hospitality and all of you for coming here this evening. By the way, Princeton plays a significant role in my story of racial murder and Black Power in a small Southern tobacco market town. I could easily have begun the narrative right here. The young African American political leader who emerged in Oxford in 1970, Benjamin Chavis, now Benjamin Chavis Muhammad, was a direct descendant of Reverend John Chavis. Reverend Chavis, who had fought in the American Revolution, came to theological school at the College of New Jersey, which is what Princeton was called in those days, and took private lessons in Greek, Latin, and theology from President John Witherspoon, a seditious Scotsman who had come here and signed the Declaration of Independence. John Chavis returned to North Carolina, where he became one of the leading preachers in the South. Chavis founded a prestigious school in Raleigh, where he educated black and white children together, until some of the white parents insisted that he separate them. For years, Chavis taught governors, senators, and the children of Supreme Court justices by day and slave children by night. But in 1832, in the wake of the Nat Turner Revolt, the North Carolina legislature passed a law banning black teaching and black preaching. Chavis protested but was forced to give up his school and moved to the Mangum place in Granville County, where he died in 1838, reportedly murdered because he refused to stop teaching black children. His descendant Benjamin Chavis became the most important leader in the black freedom movement in North Carolina, executive director of the NAACP, and later, as Benjamin Chavis Muhammad, organized the Million Man March and the Hip-Hop Summit Action Network. And so I could have picked up the thread right here in Princeton, where Chavis's illustrious ancestor studied under President Witherspoon.

In any case, getting back to my point, rather than ponder why $I$ am caught up with African American history and culture, let me ask you instead: Why is the whole world obsessed with African American history and culture? (Like many lunatics you might meet out on the street, my point is, I ain't crazy, everybody else is crazy.) But it's true. 
From the spirituals and gospel to the blues and jazz and R\&B and rock and roll and hip hop, from Malcolm and Martin to Toni Morrison and Richard Wright and James Baldwin and Alice Walker and W.E.B. Du Bois and John Hope Franklin and Maya Angelou and Zora Neale Hurston and Langston Hughes, in slang and style and sport, in language and politics, in art and oratory, the whole world echoes black America, and this has been true for a long, long time.

The world is sort of like a big minstrel show, mimicking Afro-America. When I notice a young person, black or white or otherwise, wearing a hat at an unfamiliar angle or using a fresh expression I never heard before, I may not understand what it means, but I know where it comes from.

African Americans are twelve percent of the population of one country. Their history is a brutal story of a people kidnapped, robbed of their names and languages, and ensnared for centuries in a caste system of inherited bondage, violent repression, slanderous misrepresentation, and economic exploitation; and yet their culture resonates all over the planet. Doesn't that strike you as odd? I think if we were scholars from another planet and were dropped by Earth to check it out, we might wonder, "What on earth is going on?"

I have a theory, literally a global explanation. If you walk down to the library this afternoon and spin the globe, and put your finger down at random, chances are your finger is going to land on a country where ruthless, reckless tyrants oppress the masses of people, extracting the wealth of that place and steering it all into the pockets of the privileged few, leaving little or nothing for education and health care and the things that make life sweet and good. They pull poor people's children into armies and send the armies to bring the riches of the earth back to those privileged few. Tell me when this starts to sound familiar. Put your finger down anywhere on the globe and you will almost certainly not find a democracy, but instead you will find sultans and emirs and imams and potentates and presidents who exploit and lie to the people, and if you don't like it they'll send their secret police to take you away. This has been the human condition for most people most of the time: oppression and exploitation. As Goethe said: "The world is a prison-house."

And that is why the world is obsessed with the voice of the black South, born in the bottom of a slave ship: because African American culture began in revolt against what Dr. Martin Luther King, a black Baptist from Alabama, called the "thingification" of human beings. That culture became a world-historical force because the beating heart of African American culture, from "Go Down, Moses" to Mos Def, is the eternally radical assertion that a person is not a thing. 
That is why everywhere on this earth, where people stand up for freedom and for the dignity of human personality and the essential self-ownership of each person, this tradition resonates. All over this planet, you will hear the rhythms and inflections and insights of the African American freedom struggle, because it speaks to the largest and most profound questions of what it means to be a human being.

Blood Done Sign My Name is, among other things, a product of those struggles and a reflection of that culture, even though the book is on one level the memoir of a white boy's coming of age in eastern North Carolina. It was written in the Department of Afro-American Studies at the University of Wisconsin-Madison, where the author taught "Introduction to Afro-American History" and listened to Bessie Smith, Muddy Waters, Louis Armstrong, and Dorothy Love Coates while he wrote. This story is shaped by the blues and gospel—and even has jazz inflections. To explain what I mean by that, I lean on Albert Murray's The Hero and the Blues, ${ }^{2}$ Zora Neale Hurston's Dust Tracks on a Road, ${ }^{3}$ and especially on Ralph Ellison's Shadow and Act ${ }^{4}$ and Craig Werner's A Change is Gonna Come. ${ }^{5}$

African American history is rooted in what Ralph Ellison called the underlying "impulses of African American culture: blues, gospel and jazz." I want to show how these three impulses illuminate some of the murkier, messier histories of the civil rights movement and perhaps our own predicaments in the Age of Obama. Almost a year ago, as we watched people dancing and crying in the streets of Detroit and Dar es Salaam, the gospel impulse might have seemed sufficient. The rise of Obama was gospel and global, but history has persisted, and the blues and jazz impulses may now prove more useful.

To understand how Blood Done Sign My Name speaks out of blues, gospel, and jazz, you have to think of these three genres in Werner's and Ellison's terms rather than as categories on your iPod. Werner, expanding on Ellison, explains the blues, gospel, and jazz "impulses." The blues is the most basic of the three. It begins in a brutal history. And it addresses the grittiest realities of human life: sex, money, violence, mortality, and the lack of practically everything. As Zora Neale Hurston says, "Love made and unmade." Albert Murray argues that "the blues addresses Hamlet's question - 'to be or not to be'-which is also what the question is when you wake up with the blues there again, not only all

\footnotetext{
${ }^{2}$ Albert Murray, The Hero and the Blues (New York: Vintage, 1996).

${ }^{3}$ Zora Neale Hurston, Dust Tracks on a Road (New York: Harper Perennial, 1996).

${ }^{4}$ Ralph Ellison, Shadow and Act (New York: Vintage, 1995).

${ }^{5}$ Craig Werner, A Change Is Gonna Come (New York: Plume, 1999).
} 
around your bed but also inside your head." And then the blues impulse looks those brutal truths in the eye and says, in the words of Willie Dixon: "I'm here, everybody knows I'm here." This is not twelve-bar structures or any particular bin at the music store. Blues is instead a posture of confronting the broken world by means of existential honesty, bitter poetry, and hard-won laughter. The blues impulse claims a brutal history - and not only acknowledges that brutality but refuses to deny responsibility for one's own part in it. The blues is about endurance, not innocence.

Ellison defines it best: "The blues is an impulse to keep the painful details and episodes of a brutal experience alive in one's aching consciousness, to finger its jagged grain, and to transcend it, not through the consolation of philosophy but by squeezing from it a near-tragic, near-comic lyricism. As a form, the blues is an autobiographical chronicle of personal catastrophe expressed lyrically."

The blues impulse, rather than sipping the weak tea of optimism or praying for divine intervention, braces itself with the straight whiskey of a fatalism and finitude, confessing its isolation and despair. But rather than succumb to grief, the blues artist narrates these dilemmas in ways that laugh to keep from crying and cry to keep from dying. This stoic posture was, Gerald Early argues, "born in the consciousness of a people who experienced the gut-wrenching harshness of slavery, of absorbing the absolute annihilation of their humanity, and who lived to tell the world and their former masters about it. And it is about how they reinvented their humanity in the meanwhile."

Blood Done Sign My Name is a blues history told perhaps more deeply than gospel or jazz. At its heart is the story of a brutal racial murder that cracked open a fractured community. Marches and demonstrations emerged from the First Baptist Church, but firebombs and gunfire emanated from McCoy's Pool Hall. Here is a hard story in which fragile, imperfect human beings grapple with murderous brutality without becoming monsters or giving in but not without resorting to force. The horror and frailty are forthright and personal: it wails like Ida Cox, "I'm gonna buy myself a graveyard of my own." Vengeance is not metaphorical or metaphysical but comes mixed with gasoline and Tide washing powder in quartsized Miller High Life bottles. This history unfolds in a world where, at least on the surface of things, in Flannery O'Connor's phrase, "the lame don't walk and the blind don't see, and what's dead stays that way."

Here unjust social orders do not fall merely by appeals to the conscience of the oppressor, and revolutions do not emerge in neat and morally pristine processes. The innocent die and the guilty prosper. Among the prophets is a bourbon-addled 
poet named Thad Stem, who insists that not only do we have problems, we are problems. He writes: "I really dig sharks because when they bite your damn head off, they never say it was for a good cause." On top of all that, a shadowy character named "the Gator" reminds us that when we look in the mirror, no matter our color, we see our own capacities for violence and tragedy.

But the blues don't confine human possibility, not even for the multicolored kindred of "the Gator." The gospel impulse takes us one giant step beyond the blues. Gospel begins with a brutal history, too, asking: "Were you there when they crucified my Lord?' It testifies to the same burdens that the blues carries, but it seeks to transcend those burdens by expressing itself in relation to others and to God. The gospel impulse reaches out and reaches up and moves toward higher ground. It bears witness to the burden and upholds the tradition, but it extends a hand to humanity and to God and works toward redemption. Where the blues endure, the gospel transcends.

We see the gospel impulse at work in Blood Done Sign My Name. Most obviously, there is the story of "Miss Amy's Witness," where the call of conscience transforms a church crisis into an opportunity for "old Love" to come up in our hearts. And on the bus at Destrehan Plantation, we see gospel possibility as students who have peered into the deepest abyss in American history find themselves praying together. In the words of Reverend Vernon Tyson, they "acknowledge and confess" that "we, too, like the men who once owned Destrehan Plantation, have been tempted to love things and use people, when you have called us to love people and use things. We ask your forgiveness for our complicity in these things, and in the evils of our own time, and pray your healing for our hearts." This is the essence of the gospel impulse, taking up the cross of history and reaching beyond it through powers larger than our own.

At its best moments, the African American freedom struggle distilled the gospel impulse, but simplistic histories and popular memories cling only to those, ignoring the blues realities of dreams deferred, defeated, and unfinished. We can talk more about that later. For now, suffice it to say that historians and other grownups must avoid saccharine clichés and confront blues complexities. I would add that we cannot transform bad history into good theology.

Blues and gospel both ground themselves in the way things are, while jazz imagines how they could be. Like blues and gospel, the jazz impulse is rooted in that burden of history and in traditions of addressing it. A jazz artist keeps one hand wrapped in what Ellison calls "the chain of tradition," and yet improvises outward, finding new ways of phrasing the problem and innovative means of 
dealing with it. Jazz keeps one foot on the old melody and then tries to work its way forward, keeping the world in motion. Louis Armstrong said that "jazz is music that is never played the same way once." The jazz impulse is a means of rethinking the human condition, not just an approach to the saxophone. Jazz says we don't have to do it the way we have always done it.

Blood Done Sign My Name plays the changes offered by jazz less obviously than it plays the blues or gospel. But in jazz mode it imagines the transitions of understanding to a world beyond white supremacy. It traces the brutal origins of a historical moment but leaves us open to the possibility that history "could have been much better if human beings had acted differently." It violates narrative boundaries of history, memoir, and folklore, leaving us laid open to radical retellings of all of our stories. It may not offer an easy add-water-and-stir redemption, but it opens a history in which we can see the faces of flawed, well-meaning people like ourselves, who might do much better-especially if we remember that we have the capacity to do much worse. Nothing here is inevitable except trouble, and even "trouble don't last always."

What can this blues, gospel, and jazz-inflected history of the civil rights era say to our troubles in the Age of Obama? We have asked why African American history and culture speaks to the world with such enduring power. Now we must ask several other questions. Why were they crying in the streets of Nairobi and Barcelona and Santiago and Lagos after the United States elected Barack Obama? Had you ever before seen a Third World throng dancing around an American flag that was not on fire? And how about now? What can the blues, gospel, and jazz impulses offer us as we face the Age of Obama, and not just its opening high notes?

To answer the question, it may be necessary to acknowledge that my earlier explanation of the power of African American stuff lacked one or two brass tacks. We all have a right to the tree of life, but there are less ethereal reasons for the global rise of black culture. For example, African American culture emerges in an American context, and America became the most powerful empire in the history of the world. Naturally, American culture followed the flag, and African American culture, like other U.S. products, succeeded in part because of American predominance. The world bought American stuff, and Motown and Martin were American stuff.

But the people of the world have always seen African American culture as separate from and different from America's dominion over them. And African Americans have always operated both within and outside of the mainstream 
American context. Afro-America's best writers and artists--Richard Wright, James Baldwin, Josephine Baker, and W.E.B. Du Bois, just to name a few-have been citizens of the world: both Americans and critics of America, at home in New York or Istanbul, Harlem or Havana, Nairobi or New Orleans.

Musicians such as Paul Robeson, Marian Anderson, and Nina Simone took the spirituals, gospel, the blues, and jazz around the world and held them aloft to illuminate the brutal injustice of American racial practices. During the Little Rock desegregation crisis of 1957, Louis Armstrong cancelled a State Department-sponsored tour of the Soviet Union, saying in public, "The way they are treating my people in the South, the government can go to hell. People [in Russia will] ask me what's wrong with my country, what am I supposed to say?" The voice of black America has always been global, it has always been American, and yet it has always been independent of imperial projects and discriminatory practices.

It was impossible this past January not to be struck by the fact that we were honoring Dr. King and inaugurating President Obama in the same breath. But Obama is not King, and King was not Obama. King was a truly American figure, but he became a global icon in part because of what Du Bois would have termed his "double-consciousness ... two souls, two thoughts, two unreconciled strivings, two warring ideals in one dark body, whose dogged strength alone keeps it from being torn asunder." In short, King was an American who both embodied and transcended America. Dr. King said "Unarmed truth and unconditional love will have the final word in reality." At Riverside Church in 1967, Dr. King called his own government "the greatest purveyor of violence in the world today."

So part of the world appeal of African American culture has been its critical independence, which makes it a powerful tool for critiquing America's shortcomings and for attacking tyranny around the world. But this begs the question: Can our first African American president lay down the baggage of an empire he is heading?

At first, Obama finessed the situation by citing America's imperfect history as a hedge against imperial hubris. Urging Turkey toward democratic reforms, President Obama added, "I say this as President of a country that not long ago made it hard for someone who looks like me to vote." In his visionary speech at Cairo, Obama declared "a new beginning" between America and Muslims around the world." In an appeal to end political violence in the Middle East, he again deployed African American history: "For centuries, black people in America suffered the lash of the whip as slaves and the humiliation of segregation. But it 
was not violence that won full and equal rights." If he simplified and sanitized the black freedom struggle, playing gospel where blues might speak more truth, he nonetheless set a new tone in U.S. relations with Muslims around the world.

But if the blues might recommend guarded hopes and gallows humor, clearly President Obama's strength is gospel power. In Dreams from My Father, ${ }^{6}$ he writes of the first stirrings of his Christian faith: "At the foot of that cross ... I imagined the stories of ordinary black people merging with the stories of David and Goliath, Moses and Pharoah, the Christians in the lion's den, Ezekiel's field of dry bones. Those stories - of survival and freedom and hope-became our story, my story ... at once unique and universal, black and more than black." This vision came to him at a black church in Chicago and built on the work of a white mother who raised him in Djakarta on "the recordings of Mahalia Jackson" and "the speeches of Dr. King."

This is the gospel impulse, pulling us together and pointing us toward higher ground. In this fragmented age, Obama declared to the world in his inaugural speech that "the old hatreds shall someday pass; that the lines of tribe shall soon dissolve; that as the world grows smaller, our common humanity shall reveal itself."

This African American gospel impulse has never confined itself to these shores. As Howard Thurman writes in The Luminous Darkness, "It knows no country and its allies are to be found wherever the heart is kind and the collective will and private endeavor seek to make justice where injustice abounds, to make peace where chaos is rampant, and to make the voice heard on behalf of the helpless and the weak."

Obama's gospel tone has quickly improved relations with India, China, Russia, and our European allies, though there is room for more progress. His opening to Iran drew envoys from Israel and Iran to the International Commission on Nuclear Nonproliferation and Disarmament in Cairo in late September. In October, it brought Russia, France, and the United States to Vienna for direct negotiations with Iran about its nuclear enrichment program and might yet resolve a crisis that has shadowed us for years. His cancellation of a projected Eastern European missile defense system recruited Russia to that cause and to our negotiations to reduce our respective nuclear arsenals. He has renewed our

\footnotetext{
${ }^{6}$ Barack Obama, Dreams from My Father (New York: Crown, 2007).

${ }^{7}$ Howard Thurman, The Luminous Darkness (New York: Harper \& Row, 1965).
} 
relationship with the United Nations. The Nobel Prize is largely a testament to the gospel hopes he has raised.

But blues realities besiege this president. The Pentagon is trying hard to box President Obama into a deeper plunge into the war in Afghanistan, the graveyard of empire. He has permitted his commanding general to write reports and then leak them in order to pressure him. He seems poised to succumb. Even a prowar report from the Center for American Progress says that success will require "prolonged U.S. engagement using all elements of U.S. national power" for at least another decade. Meanwhile, polls show the majority of Americans already opposed to sending more troops. As jazz artist Les McCann sang of Lyndon Johnson, "The President has got his war / Folks just don't know what it's for."

The unfolding narrative threatens to cast Obama as Lyndon Johnson, whose hopes for a Great Society sank into Southeast Asia. Before Obama accepts this role, I pray that he will read the recent resignation letter of Matthew Hoh, the senior Foreign Service official in Zabul. Hoh, a former Marine captain, resigned because, as he put it, "I have lost understanding of and confidence in the strategic purposes of the United States' presence in Afghanistan." Hoh calls the current conflict "a 35-year civil war" and says our presence is "perceived by the Pashtun people as a continued and sustained assault, going back centuries, on Pashtun land, culture, traditions, and religion" by outsiders. He goes on: "Like the Soviets, we continue to secure and bolster a failing state, while encouraging an ideology and system of government unknown and unwanted by its people." According to Hoh, "The bulk of the insurgency" is parochial and territorial, driven not by loyalty to the Taliban but by objections to foreign troops and unrepresentative government. Our strategy of denying a haven to Al-Qaeda, Hoh points out, overlooks that "the September 11 attacks, as well as the Madrid and London bombings, were primarily planned and organized in Western Europe."

In Afghanistan, we propose to build a modern state where one has never existed and establish control of places that have resisted control for centuries. Our partner in this effort is one of the most corrupt governments on earth; the president's brother is a major player in the illegal opium trade, the engineer of the recent election-rigging, and has been on the CIA payroll for years. So far, we have managed to drive nearly all of Al-Qaeda into Pakistan, which makes no sense. The current head of the CIA agrees with Matthew Hoh that Al-Qaeda will only find new havens in Somalia and Yemen. And yet we have entered our ninth year in Afghanistan and have already sacrificed \$233 billion, the lives of 850 American soldiers, and the futures of several thousand more. 
Even to contemplate Obama's dilemma, we need a little blues realism and a little blues humor. A blues sensibility understands a world in which there are no good choices; in which we have made terrible mistakes already; where we have innocent blood on our hands, even though we had our reasons; a world in which we are damned if we go deeper and damned if we duck out; a world in which we nonetheless have to make choices. As underrated theologian Bessie Smith sang: "Nineteen men living in my neighborhood/ Eighteen of them fools and the one ain't no damn good." In fact, given the state of the economy, we might also invoke Tampa Red: "When you lose your money / Make sure you don't lose your mind."

President Obama's strength is gospel, but he confronts a universe of bad choices that demand jazz improvisation. Keeping one foot on the tradition-in his case, the United States Constitution and the scriptures-Obama must relentlessly experiment with ways to recapture America's best visions of itself while making a new path through a complex world. Like the American experiment itself, jazz is a process of constant redefinition: "Jazz transforms noise into music, challenges us to hear the music in the noise, open our ears, our minds, our lives to things we hadn't thought about." Better counsel for this historical moment would be hard to find: The whole world is looking up from the blues realities of a war-torn planet, and looking toward the gospel possibilities of a jazz-inflected age when we don't have to do things the same old way.

The transcendent idea of America is that we all rise or fall together and that each and all of us have a voice. This is an idea that is rooted in the Constitution and the Declaration of Independence, but those documents were merely worthless scraps of paper before the voice of the black South rose up and redeemed them for the ages by lifting them to their highest gospel meaning. In so doing, black Southerners liberated not only themselves but many of the rest of us. And they also unleashed not only America's better angels but the highest aspirations of people all over the planet. Like the nameless enslaved poets who wrote the spirituals, we must look at the world now with eyes both old and new and remember that the blood done sign our names. 


\section{The Beauty and Terror of the Universe: John Calvin and Blaise Pascal}

by Randall C. Zachman

Dr. Randall C. Zachman, associate professor of Reformation Studies and director of the M.A. and M.T.S. Program in Theology, University of Notre Dame, gave the 2009 Warfield Lectures, titled "Ravished with Wonder: John Calvin and the God Who Is Love." He delivered this lecture, the first of the series, on October 19, 2009, in the Main Lounge, Mackay Campus Center, Princeton Theological Seminary.

$T_{\text {ha }}$ hank you again for coming this evening and also for the invitation to give these lectures. It has been a real honor and a real challenge for me to work on issues that I find very intriguing in Calvin, while also stretching out into new directions. It is a very interesting thing to bring Calvin into conversation with other people, and as you can tell, I have very gloomy people that I bring him into conversation with: Pascal and Kierkegaard, though we end with Julian of Norwich, which is pretty hard to beat. So I am looking forward to this time together and to the conversations we will have around these lectures.

This evening the subject is Calvin's understanding of the universe, and we will spend most of our time talking about the stars, the planets, the sun, what he considered to be above the lunar-sphere and beyond. This was a passionate area of interest to Calvin, and so I want to talk about what he thought about this issue, why he thought about it the way he did, and especially this phrase he uses, which we will get to, astronomy (or his word, astrology) "is the alphabet of theology." I find that absolutely fascinating. Why did he say that? We will explore a lot of the dimensions of that statement. I will then bring in Blaise Pascal, who points out, with the invention of the telescope and the microscope, that not only is the universe beautiful, which Pascal always thought, but it is also terrifying. That may also explain, I think, why this theme has virtually disappeared in theology. I find it intriguing that there are two Frenchmen, Pascal and Calvin, who 
are interested in the universe, and I cannot think of anyone else. If you know of anyone else who has this interest, let me know.

So to begin, of course I have to create space for this issue in Calvin. One of the most hotly contended issues in Calvin scholarship concerns whether, in fact, the self-revelation of God the Creator in the universe is available in any way to human beings after the fall of Adam. Calvin does not seem to be terribly optimistic at times when he talks about this issue. Echoing Paul in 1 Corinthians 1, Calvin says, "This magnificent theater of heaven and earth, crammed with innumerable miracles, Paul calls 'the wisdom of God.' Contemplating it, we ought in wisdom to have known God, but because we have profited so little by it, Paul calls us to the faith of Christ, which, because it appears foolish, the unbelievers despise." So it seems that the self-revelation of God in Creation would have been something from which we could have profited by contemplating it, but because we profited so little by it, Paul calls us to the preaching of Christ, which we regard as foolish. This, in fact, is the rhythm of Calvin's thought, that he passes from God the Creator to the knowledge of God the Redeemer, and uses this text, actually, in the Institutes as his transitional text, 1 Corinthians 1.

However, Calvin always had in mind, I would argue, that believers are to move from their faith in Christ back to the revelation of God the Creator, because their faith in Christ now reveals to them who the Creator is and what that Creator is like. So they now have the eyes to see what they beforehand could not see. So Calvin says, "Yet faith in Christ does not prevent us from applying our senses to the consideration of heaven and earth, that we may then seek confirmation in the true knowledge of God." So Calvin was convinced that what we have come to know of God in Christ, we have confirmed by what we know of God in Creation. Calvin always wanted believers to hold these two things together, that what we see in Creation is the same God that we see in Christ, and these two things mutually confirm and mutually enforce each other.

Moreover, Calvin thought that God did us a lot of favors in helping us to see this, not only by sending Christ but also by giving us spectacles, my favorite

\footnotetext{
${ }^{1}$ Peter Barth, Wilhelm Niesel, and Dora Scheuner, eds. Inst. II.vi.1, Ioannis Calvini opera selecta (Munich: Chr. Kaiser, 1926-52), vol. III, 320, lines 29-33 (henceforth, OS III.320.2933); John T. McNeill, ed. Calvin: Institutes of the Christian Religion. Translated by Ford Lewis Battles (Philadelphia: Westminster, 1960) 341 (henceforth, LCC 341).

${ }^{2}$ Wilhelm Baum, Edward Cunitz, and Eduard Reuss, eds. Comm. Genesis Argumentum, Ioannis Calvini opera quae supersunt omnia (Brunswick: A. Schwetschke and Son [M. Bruhn], 1863-1900), vol. 23, 7-8 (henceforth, CO 23:7-8); The Commentaries of John Calvin on the Old Testament, 30 vols. (Edinburgh: Calvin Translation Society, 1843-48), vol. 1, 64 (henceforth, CTS 1:64).
} 
image. Now that I have presbyopia and I cannot see anything in front of me, this is an image I especially like. Calvin describes the natural world in our fallen state as a beautiful volume that we can see without spectacles, and we know it is some sort of writing. And I know this lecture is some sort of writing, but I cannot read it, so I know something is being communicated to me, but I cannot see it. So I need scripture. He said scripture acts as spectacles to clarify this beautiful volume, which I otherwise cannot read. And so once I have scripture, I can suddenly see what it is that is being communicated to me. I think that is actually a beautiful image, or metaphor. He uses it in the Institutes and in his Genesis commentary because it conveys the fact that people do know that something is being conveyed in Creation. There is something being communicated, but they just cannot make it out, and so there is a lot of conjecture as to what it could be, but once scripture is given, you can see what is right in front of you. Calvin says, "For by the scripture as our guide and teacher, God not only makes things plain which would otherwise escape our notice, but almost compels us to behold them, as if he assisted our dull site with spectacles." I like that, "as if he almost compelled us to behold them," in other words, "LOOK!" It is not just that you could look if you want to, but LOOK! And now you can see.

Calvin thinks that God does some corrective surgery in our eyes, as well. God gives us what Calvin calls the eyes of faith, so there does seem to be some sort of retinal problem in our eyes along with our need for corrective lenses. And so believers, he thinks, those who have the Holy Spirit, those who are united to Christ, actually have the eyes that can behold what is going on in the works of God in front of them and within them. He says, "The world is rightly called the mirror of divinity. Believers, to whom God has given eyes to see, discern the sparks of his glory as it were shining out in every individual creature. The world was founded for this purpose, that it might be the theater of divine glory."4 That is a very famous line. So the theater of divine glory was founded so that we would contemplate it with our eyes and come to know God through it, and believers now have no excuse. They have faith in Christ, which yields to them the one true God, the fountain of every good thing; they have the spectacles of scripture, so they can make out what was in front of them; they have the eyes of faith, so that this can penetrate into their inner self, and so they should spend their lives contemplating this image. He says, "Therefore, as soon as the name of God sounds

\footnotetext{
${ }^{3}$ Comm. Genesis Argumentum, CO 23:9-10B; CTS 1:62.

${ }^{4}$ Comm. Hebrews 11:3, Ioannis Calvini Opera Omnia, Series II, Opera Exegetica Veteris et Novi Testamenti, Geneva: Libraire Droz, 1992-, vol. 19, 184; David W. Torrance and Thomas F. Torrance, eds., Calvin's New Testament Cominentaries (Grand Rapids: Eerdmans, 1959-72), vol. $12,160$.
} 
in our ears, or the thought of God occurs to our minds, let us also clothe God with this most beautiful ornament, the universe. Finally, let the world become our school if we rightly desire to know God." "As I have argued in several of my works, this theme in Calvin is absolutely essential to him. You cannot be a faithful person, you cannot be a godly person, you cannot be a pious person and not contemplate God's self-revelation in Creation.

But what was it in particular that Calvin wanted us to regard? What were we supposed to contemplate? Calvin says, "The Lord manifests himself by God's powers, the force of which we feel within our self, the benefits of which we enjoy." "So what we are to behold in the works of God are what Calvin calls "the powers of God." These are often translated as "the perfections of God." We often discuss them as attributes of God. But I think it is significant that Calvin calls them powers, because powers work on us. Powers are forces that we experience so that they are not just attributes that could be ascribed to God in this kind of abstract way, they are actually things that are revealed in what God does, that convey God's nature to us. God's nature, then, actually acts upon us. It is not remote at all. It is quite intimate. Of these powers in particular, Calvin's three favorite are wisdom, goodness, and power. There is a lot of discussion of these attributes, or perfections, of God in Calvin, and a lot of people seem to think that Calvin was a very anxious person. This is very hip these days. Calvin is an anxious person! So he is looking around for something to allay his anxiety and he seizes on power. He wants something powerful to take his anxiety away, so he wants power, and that makes him feel safe, that makes him feel secure. That, actually, is the last thing that Calvin would ever say. Power by itself, he thinks, is absolutely terrifying, and if all we know of God is power, we are lost. We are crushed. It just reduces us to nothing.

So Calvin always wants to frame the power of God in the context of the wisdom of God and the goodness of God, as well as the justice of God, the mercy of God, the eternity of God, and the life of God. We will see many of these powers this evening, but I think it is especially interesting that Calvin focuses on the wisdom of God. He is very interested in the wisdom of God, as the wisdom of God is the disclosure of the goodness of God, and the goodness of God is undergirded by the power of God. But I think what we will see tonight is that the power of God always supports what the wisdom of God is doing. And it is the wisdom of God that discloses the goodness of God, and it is the goodness of God that discloses God. There has been a lot of interest in Calvin on these

\footnotetext{
${ }^{5}$ Comm. Genesis Argumentum, CO 23:7-8C; CTS 1:60.

${ }^{6}$ Inst. I.v.9, OS III.53.14-16; LCC 62.
} 
attributes: perfection, powers, and the like. But I want to argue that he does not just look at power. Power to him is absolutely terrifying. Power is important, but in the context of wisdom and goodness, so those are his three favorites. And he virtually assigns a kind of Trinitarian rhythm to them. He will ascribe goodness to the Father, who is the fountain and author of every good thing, including the fountain of divinity, within the triune relations; wisdom to the Son; and power to the Spirit. Power to the Spirit. It just sounds like a slogan doesn't it? Power to the Spirit! Okay, never mind. So, power to the Spirit! Anyway, you can see that these three always work together. They are never found in separation, so you never have a power that is not wise or a goodness that is not wise, et cetera, or a goodness that is not powerful. He does not always, though, reduce the three to triune relations, and, of course, you could not, because the Son is also good and powerful and the Spirit is also wise and good, et cetera. But he still likes those three in particular. So he says, for instance, "This, indeed, is the proper business of the whole of our lives in which we should daily exercise ourselves to consider the infinite goodness, justice, power, and wisdom of God." See, there are four now, "in this magnificent theater of heaven and earth." "So it is these powers in particular to which he wants us to attend, and you can see justice is in there, so it is not always just wisdom and goodness at that point.

The goal of this consideration, and this will be the theme or the refrain of these lectures, is to become ravished with wonder and astonishment. I found this theme to be absolutely charming when I first came across it. I thought that Calvin just got carried away one day when he was writing this commentary. But this theme occurs over and over again for him. The goal of our knowledge of God and the goal of our contemplation of Creation, and especially our goal of our contemplation of the stars and the planets and the sun, is to become completely overwhelmed with awe, with astonishment, and with wonder, so that we cannot even speak at the end of this ... at the culmination of this experience. In other words, you know you have experienced these powers of God, you know that you have experienced the self-revelation of God in your contemplation, when you are completely ravished outside of yourself in wonder and are reduced to silence. But it is not a silence before language-it is a silence beyond language. And I find it absolutely amazing that this is Calvin's piety, and it is. You are seized outside of yourself by what you see, and you are rapt outside of yourself. That is what the Latin would actually mean-you are taken outside of yourself in wonder, astonishment, and awe. So he says, "As soon as we acknowledge God to be the supreme architect who has erected the beauteous fabric of the

${ }^{7}$ Comm. Genesis 2:3, CO 23:33A; CTS 1:105-106. 
universe, our minds must necessarily be ravished with wonder at his infinite goodness, wisdom, and power."

Now, Calvin was quite serious about this kind of contemplation. He thought that we should do this every minute of every day. Every minute of every day, you should be contemplating the powers of God at work around you and within you. You should be experiencing these powers, you should be enjoying these powers, and you should be rapt outside of yourself in wonder. Of course, he knows none of us do this, which is why, he thought, God instituted the Sabbath. And he thought this commandment, this part of the Sabbath commandment, was absolutely binding on Christians. This comes up, actually, in a charming exchange between the minister and the child in Calvin's 1545 Catechism. (By the way, on his deathbed, Calvin admitted to poorly writing only one work: his Catechism. $\mathrm{He}$ was very happy with everything else that he wrote, but, he said, "I really never got the Catechism right." And you will hear in this exchange, the child sounds like a tenured professor, but it is charming.) So the minister says, "But what is the meaning of the Lord exhorting us by his own example to rest?" and the child says, "When he finished the creation of the world in six days, he dedicated the seventh to the contemplation of his works. To incite us the more strongly to this, he sets before us his own example, for nothing is more to be desired than that we should be formed to God's image," which I think is quite significant. The minister says, "But our meditation of God's works is to be continuous. Is this sufficient that one day out of seven be devoted to it?" The child answers, "It is right for us to be employed in it every day. But because of our weakness, one special day is appointed." So Calvin thinks the child is quite right. You can hear the minister, "That is quite right!" I find those really charming. But I think that it is significant that he actually stops the Catechism to discuss this issue. The default position is that we should be doing this all the time, so why just one day? And the minister says well, because of our weakness, we should do this at least one day a week. But if we do not do this, we are not imaging God. If we do not do this, we are not like God because God contemplates God's works, and so should we. That is really his point. That is his exhortation. I think this is quite significant for Calvin and he thinks this is actually something Christians should do once a week. I again wonder, and I will sort of throw this out there: What happened? Where did this go? I mean, I never heard about it when I was younger. It really is interesting that it is so important to Calvin that we contemplate Creation, and yet we do not seem to have done a very good job on that.

\footnotetext{
${ }^{8}$ Comm. Psalm 19:1, CO 31:195B; CTS 8:309.

${ }^{9}$ Catechismus Ecclesiae Genevensis, OS II.103.13-22; J. K. S. Reid, trans. Calvin: Theological Treatises (Philadelphia: Westminster Press, 1954), 112.
} 
Moreover, Calvin gave a great deal of thought to how we should do this. He was a person who was very conscious of order, the order of teaching, as well as the order of contemplation, and with regard to the latter he always has us begin with heaven. God's works are done all around us; God's works are done within us. He thinks that if you are blind, you can still-with your eyes not being used at all-you can still feel the life of God within you. You can feel the power of life within you, and that life within you is God within you. He says Plato says that but God inspired Plato to say that to shame us into realizing that this is true, that our very life comes from God, and that we can all feel this life within ourselves. So in a sense, Calvin wants us to see these powers in everything we experience, in everything around us. But he knows us, and knows that it is very difficult to do, especially as we look at human history. Human history is incredibly confusing and problematic and disturbing and troubling and terrifying and all these things, and so he thought, you really have to give some attention to where you begin. How do you begin this contemplation that you are to do every day, or at least once a week? You start at night. The first thing you do is you contemplate the heavens. He always comes around to this. My question tonight is basically why, so I am going to try to play out why he does this.

In a relatively astonishing section in the Institutes, Calvin summarizes how we are to appropriate the knowledge of God the Creator. And he is talking now about the godly. What are we supposed to do with this knowledge? How are we supposed to make it our own? And he says, "Therefore, let the reader understand that he or she has a genuine apprehension of the character of God as the Creator of the world. First, if you attend to the general rule, never thoughtlessly or obliviously to overlook the glorious powers which God displays in God's creatures. And second, if you make an application to yourself of what you see, so as to fix it deeply in your heart." ${ }^{10}$ So what you contemplate should affect you deeply, and you can see that rhythm again. Then he talks about what we should contemplate in the works of God. He said the former"never thoughtlessly or obliviously to overlook the glorious powers of God"is exemplified "when we consider how great the architect must be who framed in order the multitude of the starry hosts so admirably that it is impossible to imagine a more glorious sight. So stationing some and fixing them to particular spots that they cannot move," so we can see the physics are very different, "giving a freer course to others, setting limits to their wanderings, so tempering the movement of the whole as to measure out day and night, months, years, and seasons, and at the same time so regulating the inequality of days

${ }^{10}$ Inst. I.xiv.21, OS III.171-72, LCC 181. 
as to prevent everything like confusion."11 There is no confusion. And then we contemplate God's power in sustaining so great a mass, et cetera. He says that these few examples sufficiently explain what is meant by recognizing the divine powers in the creation of the world. He is done. All he has talked about is the starry host. All he has talked about is the positioning and the movement of the planets and the stars, the sun, and moon. And he thinks that is sufficient. I think that is interesting. And I never noticed that before, that all he mentions is the heavens. I was going to move on to how it is supposed to deeply affect us, but it is quite significant, I think, that he stops at this point. So he wants us to start with the glorious powers of God at work in the heavens, and in this instance, he does not go any further than that. So I think this indicates how passionately Calvin thought about this.

Calvin is also aware that there are various ways in which we can contemplate the heavens. There is what everyone can do-and you all should be doing this, by the way, at least every week, if not every day - and that is to walk outside and look at the sky. Of course, we all cannot do this, as Calvin could, because of ambient light. Calvin would consider this to be a tremendous loss, that human beings have succeeded in securing their lives at night to such a degree that they cannot even be awestruck by the sky over them. They have a chance every day to be completely overwhelmed by the majesty of the stars and the planets, et cetera, and yet now it is blocked for most of us. If you have ever seen a map of the United States at night, it is really astonishing. The East Coast, forget it, you guys are all in trouble, you cannot see anything. The Midwestwe are too near Chicago-is pretty bad as well. The further west you go, the more you can see. I remember my wife and I were up in the Adirondacks last winter and it was this icy, cold night, when you walk out in the snow it goes crrk, crrk, crrk, like that, it is very crunchy, and we went out to the lake, which was quite expansive, and then we just stood there and we looked up. And there was no humidity, there was no ambient light, nothing, and you just feel yourself phooshh, you know, it's just like you're gone. So this is what Calvin had in mind. And imagine him in the sixteenth century at night looking up at the sky. It must have felt like the Milky Way was right there for him to touch. So he thinks everyone can do this, and everyone should do this. You do not have to be smart. You do not have to be educated. You do not have to know how to read. You have not read anything. You do not know anything. You can do this. You should do this, and you will get enough out of it by doing that. I think that is interesting. So he says that even the most illiterate peasant-he tried to teach people

${ }^{11}$ Inst. I.xiv.21, OS III.172.4-13; LCC 181. 
how to read and meant no insult by the term "illiterate"- - an see enough of the starry host to come to an understanding of the powers of God and the existence of God thereby being revealed.

But Calvin is also aware of what he calls "natural astrology." Now it is one of those things that happens in terms of names, that eventually, to distinguish the Nancy Reagan kind of astrology — and I do not mean to make fun of that, because actually Martin Luther and Philip Melancthon were deeply interested in the Nancy Reagan kind of astrology - natural astrology was given the name astronomy. We now call it astronomy, but in Calvin's day it was called astrology. So all of it was astrology: the study of the stars. But Calvin is aware that there are people who have dedicated their lives to deeply studying this subject, to studying the stars, to studying the planets, to studying eclipses, to studying comets. There is a long history, going back to human prehistory, of interest in the stars. Stonehenge comes to mind. Calvin did not know about it, yet he would not be surprised at all by it. The people he knew, especially, were the Egyptians on the one hand, and the Babylonians on the other. If you read any history of astronomy, you will know they represent very significant stations along the way. These people undertook learned investigations of the universe. They were not just contemplating it in an unlearned way, they were studying it. And Calvin commends them for this. He says, "Anyone assisted and enabled to attain a deeper insight into the secret workings of divine wisdom cannot be condemned." This is actually a good thing. He says, "To investigate the motions of the heavenly bodies, to determine their positions, measure their distances, and ascertain their properties, demands skill and a more careful examination. And where these are so employed, as the Providence of God is thereby more fully unfolded. So it is reasonable to suppose that the mind takes a loftier flight and obtains brighter views of God's glory." "12 But then he comes back to say that even the common folk and most untutored can contemplate the excellence of the art of divine wisdom. He is aware that there are some people who have studied this much more deeply than others, and he does not want them condemned. He does not want them ridiculed or left aside because they are learned and because they are elites, basically. He thinks there is something to commend in this. He thinks we can learn from these studies even if we ourselves cannot do them. He even says in his sermons on Job that every believer should be an astrologer. Every believer should be an astrologer! Whether or not you are an astrologer in the way he is talking about, in this learned way, or are in the ordinary way, everyone should be interested, passionately interested, throughout their lives, in the heavens and

${ }^{12}$ Inst. I.v.2, OS III.46.16-20, LCC 53. 
the motions of the heavens. So you have this learned investigation and then you have the ordinary comprehension or contemplation.

Calvin was also very interested in the nature of what he calls natural astrology. He wrote a work distinguishing this from what he calls judiciary astrology, which he thinks is the attempt to predict the future very precisely. "You will meet a beautiful woman and she will change your life," that kind of thing. He really did not have any time for that. But he did, in fact, think that this did not mean that the study of the heavens was a waste of time, quite the contrary. "True astrology," notice the same word, "is the knowledge of the natural order and the arrangement which God established for the stars and the planets, which involves estimating their office, property, and power and subjugating their entire science to God's end and use."13 And he thinks that the main difference is that everyone knows what the effects of astrology are, and he thinks in particular of seasons, but not everyone knows their causes. By the way, do you know that over half of the college graduates in the United States do not know why there are seasons? They do not. They probably think the way Calvin did, that the sun just goes further away and it is orbiting the earth, et cetera. It is very sad to me: such is our ignorance of astronomy now, and our indifference to it. We do not even know what we should basically know ourselves. So one of the things you learn in astronomy-I will just use the word astronomy now to avoid confusion, but he uses astrology - one of the things you discover is why seasons are the way they are, why winter and summer follow each other. So you learn the causes of things, not just their effects. Moreover he thinks that this study leads to the knowledge of eclipses. Why do lunar and solar eclipses happen? Everyone knows that they happen, but they do not know why. They do not know what the cause is, and astronomers study the natural causes of natural effects. See? And he thinks this is a very good thing.

When he finally gives his discussion or description, or if you will, definition, of astronomy, it is really quite exhaustive. I told my wife I was going to read the whole thing. She warned me it might be a little long, but I think the detail is astonishing, how interested he was in this science. He says, "Thus astrology serves to determine the courses of the planets and stars, as much to discover their duration as their path and position. Astrologers study their duration in order to know what term each planet and the Earth require to complete their circuits." How long does it take them to do their circuits? And remember, for him, the

${ }^{13}$ Mary Potter, trans., Advertissement contra L'Astrologie qu'on appelle Iudiciare, CO 7:513-42, "A Warning against Judiciary Astrology and Other Prevalent Curiosities," Calvin Theological Journal 18 (1983): 165. 
Earth is stationary and everything else is moving. And that is astonishing, if you think about it, what it would have meant for that to happen, all of this stuff moving around us. He says, "They study their positions to know how great the distance is between them, to determine whether their movements are direct, oblique, or contrary to one another. To be able to demonstrate why the sun is farther away from us in the winter than in summer, and why it stays longer with us in summer than in winter. To be able to use a compass to determine what sign of the zodiac a planet or star occupies each month, and what points of intersection it has with other planets. To know why the moon waxes or wanes as it recedes from or approaches the sun. To understand how eclipses occur, and to be able to mark their position to the last degree and minute on the compass. This foundation laid, we can tell that the effects which we see on earth follow." ${ }^{14}$ So he actually thinks there is a relationship, a natural relationship, between the movements and the positions of things in the heavens, and what happens on earth. In other words, he thinks that the earth is part of the cosmos. He thinks that it is one with everything we see in the universe. And if you see the causes going on there, you can actually conjecture, you can actually follow or extrapolate down to effects on earth. He even thinks it has medicinal uses. For instance, his doctor, Benedict Textor (we know his name, he even commends him in his commentary on the correspondence of Paul, I think, to Timothy), would do bloodlettings for Calvin based on the position of the stars. And Calvin thought this was legitimate, that you should be able to do this. And he thought clams were more productive during certain phases of the moon than others. So it is all very charming, but on the other hand, the insight, I think, endures, that we are part of the cosmos. And what happens in the remotest distances of the cosmos affects us, and what happens here affects things there.

Calvin also is aware later in his career-and I think this is quite prescient of him- of the danger that this kind of study presents, namely, the study of the natural causes of natural effects, and he writes a comment about Aristotle's treatise On Meteors. He is worried that Aristotle is attempting to create a veil that will conceal the work of God, conceal the powers of God, by accounting for everything exhaustibly by natural causality. So everything that has a natural effect has only a natural cause. And Calvin thinks that this is the danger of this kind of study: it can attempt to account exhaustively for all of the effects that we see in all the causes that we see. But Calvin does not solve the problem by appealing to miracles. He does not solve the problem by breaking the cause-effect nexus. He does not solve the problem by arguing against Aristotle. He tries to solve the

${ }^{14}$ Ibid. 
problem by arguing that this whole process of natural cause and effect manifests something vastly beyond natural causes and effects. And the awareness of that, the recognition of that, is wonder. There is not an argument to be made here. It is an appeal to the experience of wonder. You cannot look at these processes and not be astonished. And the more you understand them, the more you will be astonished. See, that is what he is trying to argue. So he is actually not afraid of these kinds of investigations. He warns us that we should not think we are explaining everything by natural causality. But on the other hand, he wants to know the natural causes of natural effects. And as you can see, he is up on his game. He gives a pretty good detailed list of what astrology was doing in the sixteenth century. So he seems to have taken an intense interest in it.

Calvin is also aware - and this is quite amazing to me-that what astrologers or astronomers tell us is not what the Holy Spirit in scripture tells us. The Holy Spirit in scripture tells us that the moon is the second great light. Astronomers tell us that the moon is opaque and reflects the sun, although Calvin thought it was in the sphere of fire, and so it must, even though opaque, have a little bit of light in it. But he knows it is basically opaque. It is not one of the lights like the sun. Moreover, scripture tells us that the moon is the second largest object in the sky, whereas astronomers tell us that Saturn is much bigger than the moon. Moses tells us through the Holy Spirit that there is water above the atmosphere, and astronomers know there is fire above the atmosphere. (A hundred years from now people are going to be laughing hysterically at what we think is absolutely true. But more of that when we get to Pascal.) In any case, this creates quite a conflict. And, of course, the United States of America has suffered deeply over the past hundred and some years over this conflict. What if the natural investigation of natural causes and effects tells you that the way things work in the universe is vastly different than what scripture says?

Now you might think this would create an insurmountable problem for Calvin, who is famous for saying (and Biblical inherentists love Calvin on this), "Our true wisdom is to embrace with meek docility, and without reservation, whatever the Holy Scriptures have delivered." ${ }^{15}$ But instead, at this point Calvin completely shifts gears. He says that scripture is written for unlearned people. In fact, this is one of his mottos. "Scripture is the book of the unlearned." Not images, as Gregory the Great says, but scripture. This means that the Holy Spirit and the human authors of scripture, including Moses, Daniel, Jeremiah, Isaiah, Jesus, and Paul, are writing for people who do not know anything, who are not

${ }^{15}$ Inst. I.xviii.4, OS III.227.27-30, LCC 237. 
learned. And you do not show off your knowledge of astronomy when you are teaching that kind of person, because they will be totally turned off and they will think, "What a jerk. I don't know what he or she is talking about; I don't have time for this." You will instead tell them things according to the way they experience the world, and you will lead them on from there. You will accommodate yourself to the lowest capacities of your audience. Not in a patronizing way, not in a condescending way, but in a respectful way, by engaging people where they actually are.

So the scriptures, which are the book of the unlearned, do not falsify the inquiries of the learned, for the learned are studying more deeply the powers of God at work in the world, and they are what reveal God to us. Calvin distinguishes between the learned investigations of what we would call scientists (he called them philosophers, as there were no scientists at this time), which are true, and the teaching of scripture, which is accommodated to ordinary comprehension and is therefore not learned. He says, "The one who would learn astronomy and other recondite arts, let him go elsewhere (than Genesis). Here the Holy Spirit would teach all people without exception, and therefore what Gregory declares falsely and in vain depicting statues and pictures, is truly applicable to the history of Creation, namely, that it is the book of the unlearned." ${ }^{16}$ And he goes on to say that Moses knew better. He was convinced that when Moses was being raised in Pharaoh's household in Egypt, he learned Egyptian astronomy. So Moses knows what Calvin knows. Daniel knows what Calvin knows. He was taught by the Babylonians, so he knows Babylonian astronomy. Calvin thought Jeremiah knew this, Amos knew this, and Isaiah knows this. When we look in the prophets we see how often they refer to the stars and the planets, so Calvin makes an interesting point. And Moses knows better when he writes about the universe in Genesis, but he is teaching people who do not know any better, and he is not going to insult them and bore them and distract them. So he does not tell them these things. But, Calvin says, here is the difference. "Moses wrote in a popular style things which without instruction, all ordinary persons endowed with common sense are able to understand. But astronomers investigate with great labor whatever the sagacity of the human mind can comprehend. Nevertheless, this study," that is, astronomy, "is not to be reprobated." And we know Calvin was not shy about reprobating things, so this is a good thing! He says, "For astronomy is not only pleasant, but also useful to be known. It cannot be denied that this art unfolds the admirable wisdom of God."17

${ }^{16}$ Comm. Genesis 1:6, CO 23:18C; CTS 1:79-80.

${ }^{17}$ Comm. Genesis 1:16, CO 23:23; CTS 1:86 
The art of astronomy, this learned art, unfolds the admirable wisdom of God. So the more you understand about Creation, the more you understand about the universe, the more you unfold the admirable wisdom of God, and this is a kind of study not to be rejected. He says, to conclude, "If the astronomer inquires respecting the actual dimensions of the stars, he will find that the moon is less than Saturn, but this is something abstruse, for to the sight it appears differently. Moses, therefore, rather, adapts this course to common usage." ${ }^{\prime 18}$ I find this absolutely astonishing. If people had been inclined to this earlier on, because Calvin is one of the very favorites of the antiscience Bible movements, we could have avoided a whole series of conundrums that I think have plagued us, for Calvin is convinced that scientific investigation is very different from scripture. And it does not mean that scripture is wrong; it just means we are not to read scripture to find out how the world works. Why would we ever have done that in the first place? Calvin thinks if you want to know how the world works, check it out! And read the Egyptians and the Babylonians. Okay, he could have thrown in the Greeks, I do not know why he never does, perhaps because they learned a lot of what they learned from the Egyptians and the Babylonians. So this is very interesting, a science or liberal art that comes from unbelievers is imminently useful for believers because it unfolds the wisdom of God, and it is the wisdom of God for which we should be searching in our contemplation of the universe. And this leads Calvin to make the claim to which I alluded earlier regarding astronomy. He says, "And indeed astrology may justly be called the alphabet of theology. For no one can with a right mind come to the contemplation of the celestial framework without being enraptured with admiration at the display of God's wisdom as well as God's power and goodness." "' So for him, astronomy, contemplating the heavens, is a fundamental and essential element of theology. And he is talking here about the Egyptians and the Babylonians, in this context. And so for Calvin, this science, this learned investigation, this learned contemplation, unfolds the admirable wisdom of God in a way that is absolutely irreplaceable and necessary, making this kind of study the alphabet of theology. You cannot really be a theologian, you cannot spell in theology, unless you study astronomy.

So my question is, why? What was it that Calvin saw in astronomy that he did not see in, say, botany, or biology or zoology? I mean, these were all in nascent form in his day, but he knew plenty about them, he knew Aristotle and Pliny on these subjects. So why was it astronomy that was the alphabet of theology? Now, my wife would say biology is the alphabet of theology, so you know, not everyone agrees with Calvin on this, so I would like to puzzle

\footnotetext{
${ }^{18}$ Comm. Genesis 1:16, CO 23:23; CTS 1:87.

${ }^{19} \mathrm{Comm}$. Jeremiah 10:1-2, CO 38:59A; CTS 18:8.
} 
this out for a bit with you if I could. One of the reasons he thinks this is true has to do with the way the wisdom of God is manifested in the order of the heavens. Calvin is very interested in how the heavens themselves display an order, display symmetry. Mentioning the stars in one of the psalms, he states more clearly that "the wonderful order which shines brightly in the face of the heavens preaches loudly that there is one God and creator of the world. And all who shall observe that amidst the vast number and variety of the stars, so regular an order and course is so well maintained, will be constrained to make this acknowledgement." ${ }^{10}$ For him there is regularity and an order in the heavens that everyone can see, and this is why astronomy is so important to him, because this order manifests the wisdom of God.

Calvin also distinguishes the order you see in the stars from the order you see in the planets and then in the sun. And remember, everything is moving. Everything is moving. He says, "As to the heavens, what do we see there? An innumerable multitude of stars so arranged as though an army were so in order throughout all its ranks and then appeared the wandering planets." The stars for him are fixed and the planets make their way through them freely, "having each its own course and then appearing amongst the stars. Then the course of the sun. How much admiration ought it to brew in us. And I say this not only for the learned but for the unlearned." He says, "They who are not amazed at such a miracle that it completes its course in a twenty-four-hour cycle, must be more than stupid." ${ }^{21}$ So Calvin's amazement is that a body the size of the sun can complete its course in the period of a day, because that is what he thinks is happening. I think, personally, spinning at 29,000 miles an hour is just as amazing as the sun going around the Earth. And so he goes on in great detail about the sun rolling through its circuit, making it a wonderful specimen of God's wisdom. What amazes him in particular is the fact that you have stationary stars and moving objects, like the sun, the moon, and the planets. And yet they do not smash into each other. My wife and I were driving around Princeton, and you all know this better than we do. It is quite astonishing how people drive in Princeton. They think that these roads are a lot bigger than they are, and so the chance of collision is quite great, as we know, when objects are moving. And for Calvin, the velocity of these bodies is astonishing. He knows the speeds are incredible, he thinks he is accounting for it by the Earth's being stationary, but the speeds really are truly incredible. And so for him the fact that this is all harmonious, and this is all orderly, manifests the wisdom of God. The power of God is also revealed, because only God could sustain such a machine, and he calls the universe a machine, this incredibly complex, this

${ }^{20}$ Comm. Isaiah 40:26, CO 37:25B; CTS 15:232.

${ }^{21}$ Comm. Jeremiah 51:15-16, CO 39:454C; CTS 21:220. 
incredibly orderly movement at this tremendous velocity. So he says, "We have a signal proof of the glorious power of God." Notice that is added to the wisdom, "that notwithstanding the immensity of the fabric of the heavens, the rapidity of their motion, and the conflicting revolutions which take place in them, the most perfect subordination and harmony are preserved and that this fair and beautiful order has been uninterruptedly maintained for ages. It is apparent, then, how the ancientness of the heavens may commend to us the singular excellency of the handiwork of God."22

Moreover, this contemplation of the orderliness of the heavens for him is actually the best way to come to an understanding of the Providence of God because God is the wisdom and the power and the goodness governing all of this, and we see a greater order in the heavens than we do anywhere else. So we need to train our eyes by looking at the wisdom of God in the heavens because that will allow us better to see it all around us. And that will allow us to see it, as he says, even in the minutest of plants. ${ }^{23}$ So the spectacles of scripture and the eyes of faith are also strengthened and nourished, if you will, by the contemplation of the wisdom of God in the heavens, so that we can start to see it where we least expect to see it, and that is around us and within our own lives and our own experience. And even, as he says, in the minutest of plants. If I had time, I would talk about how he contemplates the minutest of plants; unfortunately, I do not. But he wants this contemplation to go on further than the heavens. So the fact that there is this harmony, there are no collisions, there are no what he calls concussions, there are no disturbances - this for him is incredible. And all of this is moving at a tremendous velocity, so this should just amaze us and astonish us and just take us outside of ourselves. So I think this wisdom and this unsurpassed power are very important aspects of why he thinks astronomy is the alphabet of theology.

But there is a further point, I think, than this, and that is that astronomy dislocates us. Astronomy makes us contemplate the vastness of creation, what he calls the near-infinity of creation. When we contemplate the heavens, our earthly, carnal, self-interested, all too human preoccupations with the presence of God right here, right now, only with me, are deeply challenged because God is present in the remotest reaches of the universe in the same way God is present here. God is at work in the remotest stars of the heavens as intimately as God is at work here. God's wisdom, God's power, God's goodness is at work everywhere in the universe, and therefore, here. I think ultimately this is why this study is central to theology and to the lives of the pious, because the heavens

${ }^{22}$ Comm. Psalm 68:32, CO 31:635-36; CTS 10:43.

${ }^{23}$ Ibid. 
are the closest image we have of the infinite nature of God. The universe is not nearly as big to Calvin as it is to us, but I think the same idea would follow. When you contemplate the heavens and the vastness of them-even though they are in spheres moving around the earth, for Calvin they are still incredibly immense-that immensity humbles us in our presumption to think that God is only here where we want God to be. And it also blows through our conceptions that finitize God, that make God a controllable, comprehensible, finite thing that we can control.

Theology needs to know this: God runs the universe. God does not just operate according to your ideas, and God certainly is not captive to your ideas or our ideas. God is in control, and when we contemplate that, we lose control. When we contemplate that, we ascend, by steps, to the knowledge of God. The more incomprehensible the world becomes to us, the more we are approaching just how incomprehensible God is. But it is the incomprehensibility of the selfrevelation of God. It is the incomprehensible wisdom of God, it is the incomprehensible power of God, and it is the incomprehensible goodness of God that we are experiencing. And you are seeing it. I mean, just look, you are seeing it right there. So I think that is what he is after, why this study is so important for him. He says, "Scripture often teaches that God is in heaven. Not that God is shut up in it, but in order that we may raise our minds above the world and may not entertain any low or carnal or earthly conceptions of him. For the mere sight of heaven ought to carry us higher and transport us into admiration." ${ }^{24}$ So the mere sight of heaven just makes you realize, what was I thinking? What was I thinking? He actually has Jeremiah telling the Israelites, you think you have God boxed up in the temple? Guess again. Look at the heavens and tell me God is just in the temple. I think this is very useful advice. So the alphabet of theology, I think, is precisely this awareness of the transcendence of God that we attain through what we can see in the heavens. It is an experience of the infinitude of God through what we can contemplate, and through what we can meditate on, and through what we can even study.

But what we come to know makes our place in the universe very tenuous, and it decenters us and places God back at the center, in a way that Calvin thinks is very salutary. He says, "It could doubtless be that a person would be a thousand times filled with wonder and admiration, for the more carefully we attend to the consideration of God's works, we ourselves, in a manner, vanish into nothing. The miracles which present themselves on every side before our eyes overwhelm

${ }^{24}$ Comm. Isaiah 66:1, CO 37:436B; CTS 16:409-10. 
us." 25 So I think ultimately that is why Calvin wants us to study the heavens. Calvin thinks that in astronomy, whatever form it takes, just looking at the sky in a contemplative way, not just looking up, but contemplating it, in an ordinary way, or learning more about it and investigating it more fully in a learned way, the ultimate goal is to be ravished in astonishment and reduced to nothing. But it is a nothingness of wonder, it is a nothingness of astonishment, it is a nothingness in the face of God's glory. I really do think that for him this is the goal. He says at one point, "The contemplation of the works of God ought always to end with wonder." 26 And the wonder really is the sense of being snatched outside of yourself in awe and simultaneously being reduced to nothing.

The question becomes, and this is where I would like to turn now, what happens to our contemplation of the universe, and what happens to our experience of ourselves as members of the universe, when we take the spectacles of scripture and the eyes of faith, and add to them the telescope and the microscope? This actually happens in the time of Galileo and the time of Pascal. What is amazing to me about Pascal writing in the 1650 s is that he figured out what this meant, so you could apply his insights to the time of the Hubble telescope, I think, and you have the same story. In fact, in some ways I think Calvin fits in pretty easily with this time, as well. But I posed the question earlier, why is it that this theme in Calvin-about which he was so insistent in the Institutes, in his commentaries, in his Catechism - has virtually disappeared? Where did it go? Why don't people who claim to follow Calvin's teaching actually follow his advice to study the heavens? You cannot really follow Calvin and not do this. He was adamant about it. He had to be an astronomy nut, you know, he wants us lying on our rooftops every night being swept away in amazement. So what happened? I think part of what happened is Calvin's own sense that our wonder will reduce us to nothing, and we do not like that much, and it will reveal the infinitude of God compared with our own earthly conceptions of God, and we do not like that very much either. But the other reason is what Pascal saw as he looked through his telescope. Calvin at least thought that the machine of the universe had an order and symmetry to it and we knew where we were. We were in the center, which actually for him, as for ancient physics, is the lowest part. Most people think the world at the center of the universe means it is the most important. It is actually the garbage heap of the universe, for all the crud settles in the middle. The apex of the universe is the stars, for the stars are nearly eternal and are qualitatively different from the earth. When Dante ascends from Mount Purgatorio looking in Beatrice's eyes, he goes through the planetary spheres to the

${ }^{25}$ Comm. Jeremiah 51:15-16, CO 39:454C; CTS 21:220.

${ }^{26}$ Comm. Psalm 139:13, CO 32:381B; CTS 12:214. 
celestial spheres, and that ascent brings him closer to God. So the earth being at the center of the universe does not mean it is the most important, it actually just tells you that you are at the bottom, but at least you know where up is. And Calvin does think that the heavens are closer to God than the earth and they more clearly reveal God than the earth does. ${ }^{27}$

But Pascal, by his own investigations with the telescope, knows that there is something terribly different now. There is no "there" there anymore. We do not know where we are anymore. And we still don't. So Pascal says at one point, regarding a thoughtless person who denies religion, "When I see the blind and wretched state of humanity, when I survey the whole universe in its dumbness, its silence, and humanity left to itself with no light, as though lost in this corner of the universe, without knowing who put us here, what we have come to do, what will become of us when we die, incapable of knowing anything, I am moved to terror, like a person transported in sleep to some terrifying desert island who wakes up quite lost and with no means of escape. Then I marvel that so wretched a state does not drive people to despair." ${ }^{28}$ See, we are lost in some corner of the universe. Actually, it is worse. We are lost somewhere in the universe. There is no corner in the universe, okay? The earth is rotating at 29,000 miles an hour; the sun is traveling through space at a tremendous velocity, as well. The Milky Way, we came to know very recently, is traveling at one million miles an hour, and will eventually, they think, collide with Andromeda Galaxy. So much for harmony and symmetry, and no concussion! But even though Pascal was looking through a refractor telescope of the kind Galileo and Kepler used, and not the reflector telescopes we use today, he knew we were lost, he knew we did not know where we are anymore, and he could not believe that this did not bother people. They were not concerned about this. They did not think about it. And we don't either! This is true! We are hurtling through space, and we do not know where we are going, influenced by forces that we do not understand at all. And yet, we do not even think about it.

So Pascal is very helpful in diagnosing why it is we ignore this, for when we consider our place in the universe, it is terrifying as well as awesome, it is frightening as well as wonderful. He says, "I see the terrifying spaces of the universe hemming me in, and I find myself attached to one corner of this vast expanse without knowing why I have been put in this place rather than that, or why the brief span of life allotted to me should be assigned to me one moment

${ }^{27}$ Comm. Psalm 19:1, CO 31:194C; CTS 8:308-309.

${ }^{28}$ Blaise Pascal, Pensees, trans. A. J. Krailsheimer (London: Penguin Books, 1966), 88. 
rather than another." ${ }^{29}$ Why now? Why here? Where are we going? How did we get here? And this is for him cosmological; this is not just because he is confused. This is what he knows. He knows this in 1650. What do we know in 2009? The things we know in 2009 change every day. Astrophysics gets rewritten every day, and it gets more intense, and ever more awe-inspiring. We now know that the universe is thirteen billion light years old, and one hundred fifty-six billion light years in size, and growing every second. I read a history of astronomy in which an astronomer finally admitted, by the way, that we have no idea what a "light year" means. We just say that, but what does it mean? How far does light travel in a year? Can you imagine that? And what is a billion, by the way, let alone one hundred fifty-six billion light years? See, that is the size of the cosmos now.

Pascal sees our current dilemma very clearly. What we know of the universe is simultaneously as terrifying as it is awe-inspiring. And it is deeply threatening because we just do not understand our place in it anymore. Pascal tries to get his readers to see this by inviting us to contemplate the visible world. He points out that the whole visible world, everything we can see, is an imperceptible dot in the universe. "The whole visible world is an imperceptible dot in nature's ample bosom. No idea comes near to it. It is no good inflating our conceptions beyond imaginable space. We only bring forth atoms compared with the reality of things." ${ }^{\prime 30}$ See, even the perceptible universe is an atom in the entire universe. This is an amazing insight; I think he is right. I think he got it. But that is terrifying because of what it means when I look at myself. Look at me! I am just this tiny little dot in this imperceptible universe that is an atom compared with the whole. I am swallowed up beyond nothingness by this infinity. But then he says he wants us to look in the other direction. He wants you to approximate not infinity but nothingness. He wants you to look through a microscope, and when you look through a microscope you will see universes within universes within universes in tiny, infinitesimal things. We are finally about to spin microscopic particles at a velocity approximating the speed of light in an accelerator under the mountains of France and Switzerland, in the hope that we can discover the tiniest of the tiniest of things, as they were at the beginning of the universe. Pascal doubted we could ever do this, because for him the minutest things just become another universe and within them lies another universe, and suddenly we human beings appear to be colossal. Suddenly you cannot figure out how we do not just fall through the atomic structure around us. ${ }^{31}$

\footnotetext{
${ }^{29}$ Pensees, 158.

${ }^{30}$ Pensees, 89.

${ }^{31}$ Pensees, 90.
} 
And so our nothingness in the face of the infinity of the universe becomes our colossal scale before the nothingness below us, and this, of course, is our dilemma. We are caught in the middle of things, moving endlessly between nothingness and infinity. Indeed, we have been thrown from nothingness toward infinity, but we are neither nothing nor infinite, so we cannot touch the bottom and we cannot touch the top. And this for Pascal is why human knowledge is so fragile, why human knowledge is so precarious, why the presumption of human beings to know is so ridiculous. He is writing during a time, by the way, when people are writing encyclopedias, and some of them claim to include the knowledge of everything. And Descartes wrote a book called On the First Principles. Pascal thought this meant on the first principles of everything, which would mean that you think that reason touches the bottom and the top, and we simply we cannot do that. "For after all, what is humanity in nature? A nothing compared to the infinite, a whole compared to the nothing. A middle point between all and nothing. Who can follow these astonishing processes?" 32 I think this is actually a form of humility, a form of what one might call epistemic humility, to which Calvin himself, I think, would have been sympathetic, but from which maybe at times he could have benefited. I think we all could. I think we all talk about things without realizing that we have absolutely no idea what we are saying. And we say these things as though we are absolutely certain of what we are saying. But physics tells us in a way that Pascal would completely understand that we now know maybe 5\% of the universe- of all that could be known, we know $5 \%$. That is astonishing to me, when you look at the way physics works. It is absolutely astonishing that we only know 5\%. And for Pascal you see this is exactly where we are now. It is not surprising to him at all because if you are between the infinite and the nothing, and are floating between the two equally distant from both, then you really do not know much of anything. He says, "Such is our state. That is what makes us incapable of certain knowledge or absolute ignorance. We are floating in a medium of vast extent, always drifting uncertainly, blown to and fro. Whenever we think we have a fixed point to which we can cling and make fast, it shifts and leaves us behind. If we follow it, it eludes our grasp, slips away, and flees eternally before us. Nothing stands still for us. This is our natural state and yet the state most contrary to our inclinations. We burn with desire to find a firm footing on an ultimate, lasting base on which to build a tower rising up to infinity, but our whole foundation cracks, and the earth opens up into the depths of the abyss. ${ }^{933}$ So I think that our drive to have an infinite ground for what we know that will sustain us and hold us and

\footnotetext{
${ }^{32}$ Ibid.

${ }^{33}$ Pensees, 92.
} 
preserve us is still here; it is a desire that we all have. And we also know now, I think, that we are incapable of finding this kind of ground, because we know deep down that we are floating in a medium of vast extent, blown to and fro.

I do not think that this realization takes anything away from Calvin's insight, that this medium of vast extent is awe-inspiring. It still is beautiful. It is splendorous, it is magnificent-but it is also terrifying. Our world keeps moving, keeps constantly shifting, and we do not have a way of catching our bearings. I think all of that is salutary for us. I think knowing this actually brings us closer to God rather than further away, but it is an intimacy based on genuine, existential, ontological humility, which gives us an inner sense of our nothingness, and yet of our everythingness. I mean, it makes everything infinitely important even though things are infinitely unimportant. So these are my thoughts. I have, by the way, no solution to this dilemma. I think it may explain, though, why we do not think about it. I personally find it very, very haunting. Personally haunting. And on the other hand, in a very salutary way, the more I personally think about this, the more it actually opens me up, the more it actually makes me wonder in this kind of genuinely deep way, and the less concerned I become with what used to preoccupy me earlier in my life, namely, with getting everything right. You know, we tend to think, especially in theology, that if we are not right, the universe ends tomorrow. But this is why we need astronomy as the alphabet of theology, because we cannot get it right most of the time, and yet the universe is not going to end tomorrow. There is a God at work in the universe, sustaining it and ordering it in astonishingly wonderful and terrifying ways, and all we can do is to lay our lives in the hands of this God. That is what trust is, that is what faith is-laying your life in the hands of that Creator, in light of the magnitude of that Creator's work. 


\section{Faculty Publications 2008}

\section{Kenneth G. Appold}

"Academic Life and Teaching in Post-Reformation Lutheranism." In Lutheran Ecclesiastical Culture, 1550-1675, R. Kolb, ed. Leiden: Brill Academic, 2008. Pp. 65-115.

"Barclay, Robert." The New Westminster Dictionary of Church History, Vol. 1: The Early, Medieval and Reformation Eras. Robert Benedetto, ed. Westminster: John Knox, 2008. P. 71.

"Belgic Confession." The New Westminster Dictionary of Church History, Vol. 1: The Early, Medieval and Reformation Eras. Robert Benedetto, ed. Westminster: John Knox, 2008. P. 79.

"Brès, Guy de." The New Westminster Dictionary of Church History, Vol. 1: The Early, Medieval and Reformation Eras. Robert Benedetto, ed. Westminster: John Knox, 2008. Pp. $103 \mathrm{f}$.

"Farel, Guillaume. The New Westminster Dictionary of Church History, Vol. 1: The Early, Medieval and Reformation Eras. Robert Benedetto, ed. Westminster: John Knox, 2008. P. $239 f$.

"Hardenberg, Albert." The New Westminster Dictionary of Church History, Vol. 1: The Early, Medieval and Reformation Eras. Robert Benedetto, ed. Westminster: John Knox, 2008. P. 294f.

"Olevianus, Kaspar." The New Westminster Dictionary of Church History, Vol. 1: The Early, Medieval and Reformation Eras. Robert Benedetto, ed. Westminster: John Knox, 2008. P. 474f.

"Pirckheimer, Caritas." The New Westminster Dictionary of Church History, Vol. 1: The Early, Medieval and Reformation Eras. Robert Benedetto, ed. Westminster: John Knox, 2008. P. 523.

"Pirckheimer, Willibald." The New Westminster Dictionary of Church History, Vol. 1: The Early, Medieval and Reformation Eras. Robert Benedetto, ed. Westminster: John Knox, 2008. P. 523. 
"Travers, Walter." The New Westminster Dictionary of Church History, Vol. 1: The Early, Medieval and Reformation Eras. Robert Benedetto, ed. Westminster: John Knox, 2008. P. 649f.

"Vermigli, Peter Martyr." The New Westminster Dictionary of Church History, Vol. 1: The Early, Medieval and Reformation Eras. Robert Benedetto, ed. Westminster: John Knox, 2008. P. $663 \mathrm{f}$.

"Westminster Assembly." The New Westminster Dictionary of Church History, Vol. 1: The Early, Medieval and Reformation Eras. Robert Benedetto, ed. Westminster: John Knox, 2008. P. $675 \mathrm{f}$.

"Westminster Confession." The New Westminster Dictionary of Church History, Vol. 1: The Early, Medieval and Reformation Eras. Robert Benedetto, ed. Westminster: John Knox, 2008. P. 676.

\section{Charles L. Bartow}

"Performance Study in Service to the Spoken Word in Worship." In Performance in Preaching: Bringing the Sermon To Life, Jana Childers and Clayton J. Schmit, eds. Grand Rapids: Baker Academic, 2008. Pp. 211-23.

\section{Clifton Black}

The Eighth Day of Creation: An Anthology of Christian Scripture. Grand Rapids: Eerdmans, 2008.

Words Well Spoken: George Kennedy's Rhetoric of the New Testament. Edited with Duane F. Watson. Studies in Rhetoric and Religion 8. Waco: Baylor University Press, 2008.

"Redaction Criticism." In Encyclopedia of the Historical Jesus, Craig A. Evans, ed. New York: Routledge/Taylor \& Francis, 2008. Pp. 491-95.

"Mark, John." In The New Interpreter's Dictionary of the Bible, Katherine Doob Sakenfeld, ed. Volume 3: I-Ma. Nashville: Abingdon, 2008. P. 81.

"Introduction" (with Duane F. Watson). In Words Well Spoken: George Kennedy's Rhetoric of the New Testament, C. C. Black and D. F. Watson, eds. Studies in Rhetoric and Religion 8. Waco: Baylor University Press, 2008. Pp. 1-5.

"Kennedy and the Gospels: An Ambiguous Legacy, a Promising Bequest." In Words Well Spoken: George Kennedy's Rhetoric of the New Testament, C. C. Black and D. F. Watson, eds. Studies in Rhetoric and Religion 8. Waco: Baylor University Press, 2008. Pp. 63-80.

"Lectionary Exegesis of Acts 7:55-60 (Fifth Sunday of Easter, Year A: 20 April 2008), Acts 17:22-31 (Sixth Sunday of Easter, Year A: 27 April 2008), Acts 1:6-14 (Seventh Sunday of Easter: 4 May 2008)," workingpreacher.com, St. Paul: Luther Seminary, 2008. 
"Windows, Gateways, and Mirrors: The Parables of Jesus." Dialogue: A Journal of Religion and Philosophy 31 (2008): 37-46.

Review of "Paul the Reluctant Witness: Power and Weakness in Luke's

Portrayal," by Blake Shipp. Catholic Biblical Quarterly 70 (2008):

393-94.

Catholic Biblical Quarterly, Associate Editor

\section{Sally A. Brown}

Cross Talk: Preaching Redemption Here and Now. Louisville: Westminster John Knox Press, 2008.

"Soteriology." In The New Interpreters Handbook of Preaching, Paul S. Wilson, ed. Nashville: Abingdon Press, 2008.

\section{Donald Capps}

Jesus the Village Psychiatrist. Louisville: Westminster John Knox Press, 2008.

The Decades of Life: A Guide to Human Development. Louisville: Westminster John Knox Press, 2008.

Laughter Ever After ... Ministry of Good Humor. St. Louis: Chalice Press, 2008.

Deadly Sins and Saving Virtues. Korean translation. Trans. Jin Young Kim. Seoul: Publishing House of the Presbyterian Church of Korea, 2008.

"Was William James a Patient at McLean Hospital for the Mentally Ill?"' Pastoral Psychology 56 (2008): 295-320.

"Whistler's Mother: Devotional Center of Male Melancholic Religion." Pastoral Psychology 56 (2008): 375-401.

"Mother, Melancholia, and Dreams in Erik H. Erikson's Insight and Responsibility." Journal of Religion and Health 47 (2008): 103-17.

"Mother, Melancholia and Humor in Erik H. Erikson's Earliest Writings." Journal of Religion and Health 47 (2008): 415-32.

"Alzheimer's Disease and the Loss of Self." Journal of Pastoral Care \& Counseling 62 (2008): 19-28.

"Aging Horses and Wounded Healers." Journal of Pastoral Care and Counseling 62 (2008): 293-96.

"Erik H. Erikson, Norman Rockwell, and the Therapeutic Functions of a Questionable Painting." American Imago 65 (2008): 191-228.

"The Mother Relationship and Artistic Inhibition in the Lives of Leonardo da Vinci and Erik H. Erikson." Journal of Religion and Health 47 (2008): 560-76. 
Donald Capps and Nathan S. Carlin, "The 'Religiously Mediated Change' of Eleven Gay Men: A Case of Unexceptional Sublimation." Pastoral Psychology 57 (2008): 125-46.

Nathan S. Carlin and Donald Capps, "Consciousness, the Vegetative State, and the Intrinsic Value of Life." Pastoral Psychology 57 (2008): 223-34.

\section{James H. Charlesworth}

The Historical Jesus: An Essential Guide. Nashville: Abingdon Press, 2008.

Editor, with Gerbern S. Oegema, The Pseudepigrapha and Christian Origins: Essays from the Studiorum Novi Testamenti Societas. Jewish and Christian Texts in Contexts and Related Studies 4. New York: T\&T Clark, 2008.

"The Parables of Enoch and the Apocalypse of John." In The Pseudepigrapha and Christian Origins. New York: T\&T Clark, 2008. Pp. 193-242.

"Symposium on Afterlife and Burial Practices in Second Temple Judaism," PTS Web, February 2008.

"Rebutting Sensational Claims Concerning a Symposium in Jerusalem," SBL Forum (Web), February 2008.

"Jesus and His Semitic Culture." In The Historical Jesus? Necessity and Limits of an Inquiry, E. Nodet, translated by J. E. Crowley. Jewish and Christian Texts Series 3. New York: T\&T Clark. Pp. 1-3.

"Hat die Archäologie Bedeutung für die Jesus-Forschung?" Evangelische Theologie 68 (2008): 246-65.

"The Temple, Purity, and the Background to Jesus' Death." In Revista Catalana de Teologia 38.2 (2008): 395-442.

With M. Aviam, "Überlegungen zur Erforschung Galiläas im ersten Jahrhundert," in Jesus und die Archäologie Galiläas, C. Claussen and J. Frey, eds. Biblisch-Theologische Studien 87. Neukirchen-Vluyn: Neukirchener Verlag. Pp. 93-127.

"An Unknown Dead Sea Scrolls Fragment of Deuteronomy XXVII 4-6," The Samaritan News 1019-1020 (8 August 2008). Pp. 64-68.

"Writings Ostensibly Outside the Canon," in Exploring the Origins of the Bible: Canon Formation in Historical, Literary, and Theological Perspective, C. A. Evans and E. Tov, eds. Acadia Studies in Bible and Theology. Grand Rapids: Baker Academic, 2008. Pp. 57-85.

"Adder." In Encyclopedia of the Bible and its Reception, 2008.

"An Unknown Dead Sea Scrolls Fragment of Deuteronomy," ijco.org [with an image]. 
"Announcing a Dead Sea Scrolls Fragment of Nehemiah," ijco.org [with two images].

"The Odes of Solomon: Jewish, Christian, or Gnostic," http://www.ijco.org/?cat egoryId=25992\&itemId $=41982$.

"Pour savoir ce qu'était Jérusalem avant sa destruction, il faut lire Jean," Le Point 1 (décembre 2008-janvier 2009): 24-25.

"The Dignity of the Human: Imago Dei," Inaugural Truman G. Madsen Lecture on Eternal Man. Provo: Brigham Young University: The Wheatley Institution.

\section{Ellen T. Charry}

Ceremonies that Consecrate and Heal." In Immersed in the Life of God: The Healing Resources of the Christian Faith, Paul L. Gavrilyuk, Douglas M. Koskela, and Jason E. Vickers, eds. Grand Rapids: Eerdmans, 2008. Pp. 86-108.

"Experiencing Salvation Liturgically." In Theology in Service of the Church, Charles Wiley, et al., eds. Louisville: Westminster John Knox Press, 2008. Pp. 57-67.

\section{Stephen D. Crocco}

"Dikran Y. Hadidian (1920-2007)." In Summary of Proceedings, Sixty-Second Annual Conference of the American Theological Library Association, Sara Corkery, ed. Chicago: American Theological Library Association, 2008. Pp. 375-76.

Princeton Seminary Bulletin, Editor

\section{Kenda Creasy Dean}

"Preaching to Youth." In The New Interpreter's Bible Handbook for Preaching, Paul Scott Wilson, Cleophus LaRue, and Jana Childers, eds. Nashville: Abingdon Press, 2008.

Review of "After the Baby Boomers: How Twenty- and Thirty-Somethings Are Shaping the Future of American Religion," by R. Wuthnow. Theology Today 65 (2008): 256-62.

Theology and Youth Ministry Book Series, General Editor

Praktiese Teologie in Suid-Afrika/Practical Theology in South Africa, Editorial Board

Journal of Youth and Theology, Editorial Board Journal of Student Ministries, Editorial Board 


\section{F. W. DobBS-AllsopP}

"Psalm 133: A (Close) Reading." Journal of Hebrew Scriptures 8 (2008): 30 pp. (http://www.arts.ualberta.ca/JHS/Articles/article_97.pdf).

"Lamentations from Sundry Angles: A Retrospective." In Lamentations in Ancient and Contemporary Cultural Contexts, N. Lee and C. Mandolfo, eds. Atlanta: SBL, 2008. Pp. 13-25.

\section{Gordon GrahaM}

Ethics and International Relations, Second Edition. Malden: Blackwell Publishing.

Universities: The Recovery of an Idea, Second Edition. Exeter: Imprint Academic.

\section{Darrell Guder}

"Incarnation and the Church's Evangelistic Mission." In The Study of Evangelism: Exploring a Missional Practice of the Church, Paul W. Chilcote and Laceye C. Warner, eds. Grand Rapids: Eerdmans, 2008. Pp. 171-84.

"Practical Theology in the Service of the Missional Church." In Theology in Service of the Church: Essays in Honor of Joseph D. Small, Charles A. Wiley, Sheldon W. Sorge, Chip Andrus, and Barry A. Ensign-George, eds. Louisville: Geneva Press, 2008. Pp. 13-22.

"Die biblische Prägung missionarischer Gemeinden: Missionarische Ekklesiologie und Hermeneutik." In Kirche in der Postmoderne [Beiträge zu Evangelisation und Gemeindeentwicklung, Vol. 6], Martin Reppenhagen and Michael Herbst, eds. Neukirchener Vluyn: Neukirchener Verlag, 2008. Pp. 201-20.

"Missional Hermeneutics: The Missional Authority of Scripture." In Mission Focus: Annual Review. Elkhart: AMBS, 2007. Vol. 15. Pp. 106-21.

"Missional Hermeneutics: The Missional Vocation of the Congregation and How Scripture Shapes that Calling." In Mission Focus: Annual Review. Elkhart: AMBS, 2007. Vol. 15. Pp. 125-42.

"Evangelism: North America." In Religion Past and Present/Religion in Geschichte und Gegenwart. Leiden: Brill, 2008. Vol. IV. Pp. 698-700.

Review of "A Ministry Shaped by Mission," by Paul Avis. Theology Today 65 (2008): 275-76. 


\section{SCOTT H. HENDRIX}

Masculinity in Reformation Europe. Edited with Susan C. Karant-Nunn. Sixteenth Century Essays \& Studies 83. Kirksville: Truman State University Press, 2008.

"The Future of Luther's Theology." Dialog: A Journal of Theology 47 (2008): 125-35.

"Überlegungen zum Schreiben einer Theologie Luthers." Lutherjahrbuch 75 (2008): 9-30.

\section{George Hunsinger}

The Eucharist and Ecumenism: Let Us Keep the Feast. New York: Cambridge University Press, 2008.

Torture Is a Moral Issue: Christians, Jews, Muslims, and People of Conscience Speak Out. Grand Rapids: Eerdmans, 2008.

"The Trinity and Election: Twenty-five Theses." Modern Theology 24 (2008): 179-98.

\section{JEREMY M. HutTON}

"Jordan River." In New Interpreter's Dictionary of the Bible, Katharine Doob Sakenfeld, ed. Nashville: Abingdon, 2008. 3.385-392.

"'Bethany Beyond the Jordan' in Text, Tradition, and Historical Geography." In Biblica 89, 2008. Pp. 305-28.

Biblical Theology Bulletin, Associate Editor (beginning September, 2008)

\section{William Stacy Johnson}

"Norris's Contribution to the Quest for Marriage Equality." The Anglican Theological Review 90/3 (Summer 2008): 583-88.

\section{JAMES F. KAY}

"Blackduck." In From Midterms to Ministry: Practical Theologians on Pastoral Beginnings, Allan Hugh Cole Jr., ed. Grand Rapids: Eerdmans, 2008. Pp. 51-64.

"Proclamation, Theology of." In New Interpreter's Handbook of Preaching, Paul Scott Wilson et al., eds. Nashville: Abingdon, 2008. Pp. 493-98.

"Service for the Lord's Day: Reformation Sunday 2008." In Resources for Celebrating Reformation Sunday 2008. Washington, D.C.: Reformed Institute of Metropolitan Washington, 2008. Pp. 5-11. Accessible at http://www .reformedinstitute.org.

"Christian Atheism." Theology Today 65 (July 2008): 139-43. 
"Recalled." Theology Today 64 (January 2008): 417-21.

Theology Today, Editor

\section{JACQueline LAPSLEY}

"Look! The Children and I Are as Signs and Portents in Israel: Children in Isaiah." In The Child in the Bible, Beverly R. Gaventa and Terence Fretheim, eds. Grand Rapids: Eerdmans, 2008.

\section{Elsie McKee}

"Calvijns onderwijs in de vroomheid." In Johannes Calvijn. zijn leven, zijn werk, Willem Balke, J.C. Klok, and Willem van 't Spijker, eds. (Ampen: Kok, 2008). Pp. 319-20.

"Lex Credendi'? Katharina Schütz Zell's Prayers." In Bewegung und Beharrung. Aspekte des reformierten Protestantismus, 1520-1650. Festschrift für Emidio Campi, Christian Moser and Peter Opitz et al., eds. (Leiden: E. J. Brill, 2009). Pp. 383-93.

"Katharina Schütz Zell." In The New Westminster Dictionary of Church History. Volume One. The Early, Medieval, and Reformation Eras, Robert Benedetto et al., eds. (Louisville: Westminster John Knox Press, 2008). Pp. 597-98.

"Mathew Zell." In the New Westminster Dictionary of Church History. Volume One. The Early, Medieval, and Reformation Eras, Robert Benedetto et al., eds. (Louisville: Westminster John Knox Press, 2008). P. 688.

"Calvin and Piety." In Calvin Handbook, Herman Selderhuis, ed. (Dutch, Kampen: Kok, 2008, pp. 515-22; German, Tübingen: Mohr Siebeck, 2008, pp. 459-66).

"Calvin's Understanding of Piety." Presbyterian Outlook (Oct. 13, 2008): $17-18$.

\section{Daniel Migliore}

The Power of God and the Gods of Power. Louisville: Westminster John Knox Press, 2008.

"The Love Commandments: An Opening for Christian-Muslim Dialogue?" Theology Today 65 (2008): 312-30.

\section{JaMes H. Moorhead}

"Presbyterian Confessional Identity and Its Dilemmas." In Holding on to the Faith: Confessional Traditions in American Christianity, Douglas A. 
Sweeney and Charles Hambrick-Stowe, eds. (Lanham: University Press of America, 2008). Pp. 47-70.

"Mainstream Presbyterians: Putting the Pieces Together Again after the Fundamentalist Controversy." Journal of Presbyterian History 86 (Fall/Winter 2008): 71-78.

Review of The New England Theology: From Jonathan Edwards to Edwards Amasa Park, Douglas A. Sweeney and Allen C. Guelzo, eds. (Grand Rapids: Baker Academic, 2006). Journal of Presbyterian History 86 (Fall/Winter 2008): 87-88.

Review of The Shaping of Ulster Presbyterian Belief and Practice, 1770-1840, Andrew R. Holmes (Oxford: Oxford University Press, 2006). Journal of Presbyterian History 86 (Fall/Winter 2008): 91-92.

Journal of Presbyterian History, Senior Editor

\section{Dennis T. Olson}

"Pentateuchal Narratives." In The New Interpreter's Bible Handbook of Preaching, Paul Wilson, ed. (Nashville: Abingdon, 2008).

\section{Peter J. Paris}

"King's Vision of America: An Ethical Assessment." Theology Today, Special Spring Issue Commemorating the 40th Anniversary of Martin Luther King, Jr.'s Assassination. 65, 1 (2008): 17-25.

"Moral Theatre in the Streets: The Role of Suffering in the Quest for Social Justice," The Annual Martin Luther King Jr. Lecture. Princeton Seminary Bulletin 29 (2008): 39-53.

"Religion, Race, and Gender in the Presidential Election," http://www .religiondispatches.org/archive/politics/667/.

"African American Religion and Public Life: An Assessment." In Religious Communities and Global Cities: A Tribute to Lowell Livezey. Cross Currents 58, 3 (Fall 2008): 475-94.

\section{Luke A. Powery}

"Holy Spirit/Passion." In New Interpreter's Bible Handbook of Preaching, Paul Wilson, Jana Childers, Cleophus J. LaRue, and John Rottman, eds. (Nashville: Abingdon Press, 2008). Pp. 308-10.

"Postcolonial Criticism." In New Interpreter's Bible Handbook of Preaching, Paul Wilson, Jana Childers, Cleophus J. LaRue, and John Rottman, eds. (Nashville: Abingdon Press, 2008). Pp. 159-61.

"Walkin' the Talk: The Spirit and the Lived Sermon." The African American Pulpit 11, 4 (Fall 2008): 20-22. 
"Preaching as the Spirit Moves." Circuit Rider (August/September/October 2008): 4-5.

"Jesus and Hip Hop Culture/Young Adults Sunday (Rev. 5:1-14)," "Men's Day (Ephesians 6:10-17)," "Revival I (Ezekiel 37:1-14)," "Revival II (2 Kings 7:1-20)." The African American Lectionary, Year One, www .theafricanamericanlectionary.org, April-August 2008.

Review of African American Christian Worship, 2nd ed. Melva Wilson Costen (Nashville: Abingdon Press, 2007). Black Theology: An International Journal 6/3 (2008): $403-405$.

\section{Luis N. Rivera-PaGán}

"Pentecostal Transformation in Latin America." In A People's History of Christianity, Vol. 7: Twentieth-Century Global Christianity, Mary Farrell Bednarowski, ed. (Minneapolis: Fortress Press, 2008). Pp. 190-210, 413-16.

"Completing the Afflictions of Christ: Archbishop Oscar Arnulfo Romero," Apuntes (Perkins School of Theology, Southern Methodist University, Dallas, Texas), 28, 2 (Summer 2008): 65-78.

"Libertad de culto y religión en América Latina," América Latina en Movimiento (Quito, Ecuador), xxxii, 434 (julio 2008): 31-32.

"Xenophobia or Xenophilia? A Challenge to Christian Ethics." Guyana Journal 13, 7 (July 2008): 12-15.

Review of Catolicismo y política en Puerto Rico bajo España y Estados

Unidos, siglos XIX y XX, Samuel Silva Gotay (Editorial de la Universidad de Puerto Rico, 2005). Signos de Vida 48 (junio de 2008): 15-17.

Review of Cave of the Jagua: The Mythological World of the Tainos, by Antonio M. Stevens-Arroyo. CENTRO Journal of the Center for Puerto Rican Studies, 20, 1 (Spring 2008): 256-59.

\section{Paul Rorem}

"Negative Theologies and the Cross," Harvard Theological Review 101, 3-4 (2008): 451-64.

"The Early Latin Dionysius: Eriugena and Hugh of St. Victor," Modern Theology 24, 4 (2008): 601-14.

Lutheran Quarterly, Editor

Lutheran Quarterly Books (Eerdmans), Editor. 


\section{Katharine Doob SaKenfeld}

"Whose Text Is It?" (presidential address given to the Society of Biblical Literature, November 18, 2007), Journal of Biblical Literature, 127 (2008): 5-18; reprinted in Princeton Seminary Bulletin 29 (2008): 67-81.

Review of "Great Women of the Bible in Art and Literature," by D. Soelle and J. H. Kirchberger. Theology Today 65 (2008): 136.

\section{Max L. Stackhouse}

"The New Moral Context of Economic Life." In Wealth, Poverty, and Economy in God's World, H. R. Pieterse, ed. (Nashville: The United Methodist Church General Board of Higher Education, 2008). Pp. 22-36.

"Civil Religion, Political Theology, and Public Theology: What's the Difference?" In The Christian in Public: Aims, Methodologies and Issues in Public Theology: Beyers Naudé Centre Series on Public Theology, vol. 3.

L. Hansen, ed. (Stellenbosch: Sun Press, 2008). Pp. 79-95. (Winner: Andrew Murray-Desmond Tutu Prize.)

"How and Why We Go Public." In Transforming Praxis: God, Community and Church: Essays in Honour of Dr. I. J. Mohan Razu, C. I. David Joy, ed. (New Delhi: UTC \& ISPCK, 2008). Pp. 37-46.

"Ernst Troeltsch." In The Encyclopedia of Christianity, vol. 5, written with F. W. Graf; E. Fahlbusch, et al., eds. (Grand Rapids: Eerdmans, 2008). Pp. 553-55.

"Public Theology and Democracy's Future." In Templeton Lectures on Religion and World Affairs. Harvey Sicherman, ed. (Philadelphia: Foreign Policy Research Institute, 2008). Pp. 26-33.

\section{J. Wentzel Vrede van Huyssteen}

"The Philosophical Roots of Public Theology." In A Faithful Witness: Essays in Honour of Malan Nel, H. J. C. Pieterse and C. H. Tesnaar, eds. Wellington: Bible Media, 2008.

"Primates, Hominids, and Humans: From Species Specificity to Human Uniqueness? A Response to Barbara J. King, Gregory R. Peterson, Wesley J. Wildman, and Nancy R. Howell." ZYGON: Journal of Religion and Science 43, 2 (June 2008): 505-26.

"Ethics and Christology: Rediscovering Jesus in Evolutionary History." Essays in Honour of Conrad Wethmar, Verbum Et Ecclesia 29, 2 (2008).

Co-Editor, with Roger Trigg, of the Ashgate Series in Science and Religion 
Co-Editor, with Khalil Chamcham, of the Templeton Science and Religion Series

\section{J. Ross WAGNER}

The Word Leaps the Gap: Essays on Scripture and Theology in Honor of Richard B. Hays. Edited by J. Ross Wagner, C. Kavin Rowe, and A. Katherine Grieb (Grand Rapids: Eerdmans, 2008).

"Greek Isaiah and the Septuagint as Christian Scripture." In Scripture's Doctrine: Studies in the New Testament's Normativity for Christian Dogmatics. Markus Bockmuehl and Alan Torrance, eds. (Grand Rapids: Baker Academic, 2008). Pp. 17-28.

"Faith and Fear, Stumbling and Salvation: Receptions of LXX Isaiah 8:11-18 in the New Testament." In The Word Leaps the Gap: Essays on Scripture and Theology in Honor of Richard B. Hays. Edited by J. Ross Wagner, C. Kavin Rowe, and A. Katherine Grieb (Grand Rapids: Eerdmans, 2008): Pp. 76-106. 


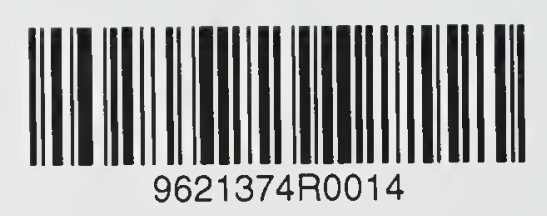

Made in the USA Charleston, SC

27 September 2011 



\section{P R I N C E T O N S E M I N A R Y B U L L E T I N}

A record of Christian thinking at Princeton Theological Seminary

Editor's Note

Crocco

Finding Ourselves Lost

Dykstra

Tracks of My Tears

Powery

Africa's Hands: Pentecostalism and Independency

Anderson

The Role of Feminism(s) in Theology and the Church: Reflections from a

Feminist Pastoral Theologian

Cooper-White

Getting Calvin Right: How Karl Barth Changed

Our Reading of the Reformer

Elwood

Ministry in the Subjunctive Mood

Jarvis

Theology of Providence

Fergusson

Politics in the Christian Life

Lovin

Containing Runaway Fear

May

Karl Barth and Contemporary Paganism: Toward a Theology without Nature

Time, the Lectures, and Redemption

Myers

Blood Done Sign Our Names: Blues, Gospel, and Jazz Impulses in the

Age of Obama

Tyson

The Beauty and Terror of the Universe: John Calvin and Blaise Pascal

Zachman

Faculty Publications 2008 